Editora Poisson

(organizadora)

\title{
Série Educar - Volume 40 \\ Prática Docente
}

\author{
1a Edição \\ Belo Horizonte \\ Poisson \\ 2020
}


Editor Chefe: Dr. Darly Fernando Andrade

\section{Conselho Editorial}

Dr. Antônio Artur de Souza - Universidade Federal de Minas Gerais

Ms. Davilson Eduardo Andrade

Dra. Elizângela de Jesus Oliveira - Universidade Federal do Amazonas

Msc. Fabiane dos Santos

Dr. José Eduardo Ferreira Lopes - Universidade Federal de Uberlândia

Dr. Otaviano Francisco Neves - Pontifícia Universidade Católica de Minas Gerais

Dr. Luiz Cláudio de Lima - Universidade FUMEC

Dr. Nelson Ferreira Filho - Faculdades Kennedy

Ms. Valdiney Alves de Oliveira - Universidade Federal de Uberlândia

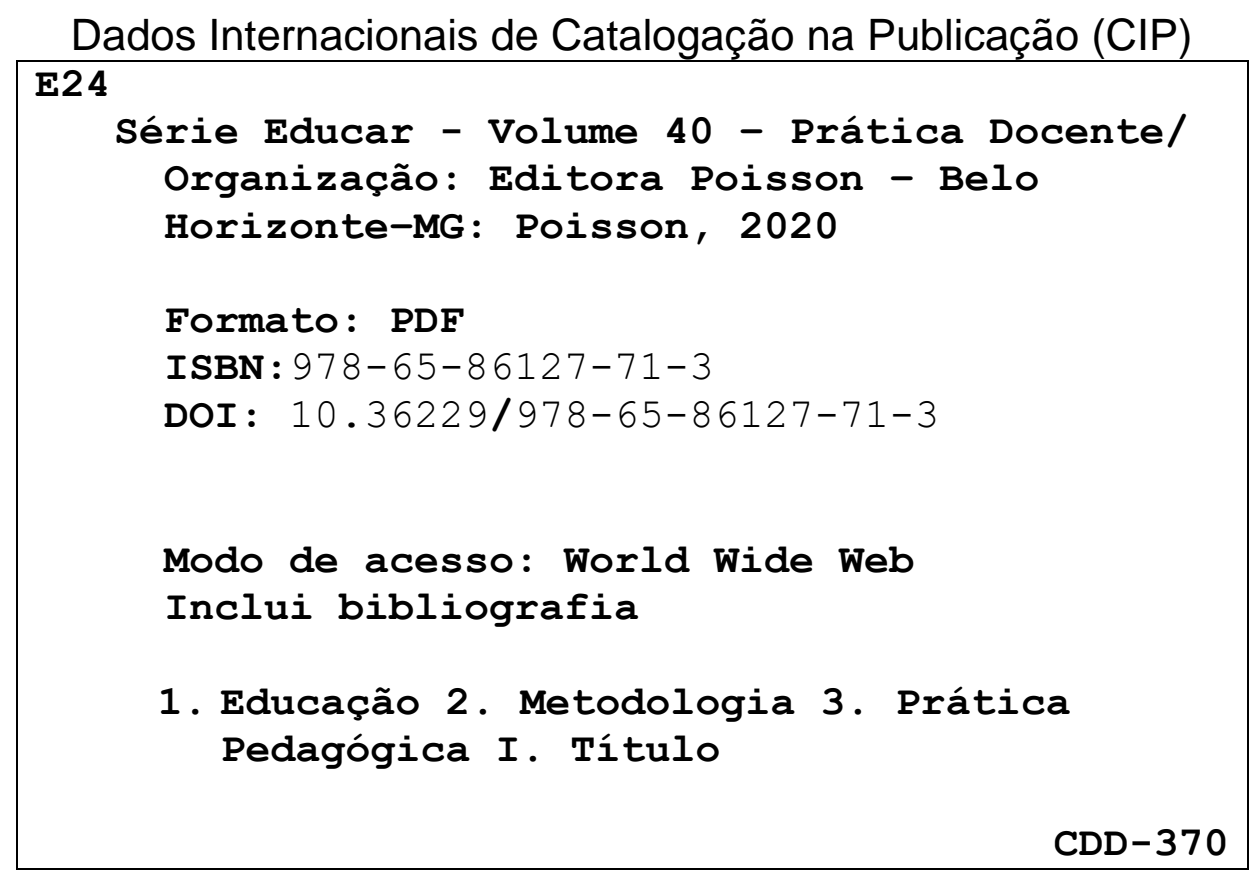

O conteúdo dos artigos e seus dados em sua forma, correção e confiabilidade são de responsabilidade exclusiva dos seus respectivos autores

www.poisson.com.br

contato@poisson.com.br 


\section{SUMÁRIO}

Capítulo 1: Metodologias ativas e suas contribuições no processo de ensinoaprendizagem 8

Joabio Alekson Cortez Costa, Júlia Diniz de Oliveira, Denis Rodrigues Dantas

DOI: 10.36229/978-65-86127-71-3.CAP.01

Capítulo 2: Mapas conceituais como elementos provedores de ensino-aprendizagem numa perspectiva epistemológica construtivista sociointeracionista 15

Mayara Lopes de Freitas Lima, Alberes Lopes de Lima

DOI: $10.36229 / 978-65-86127-71-3 . C A P .02$

Capítulo 3: Programa Aprendizagem para o $3^{\circ}$ Milênio (A3M): Ações criativas/inovadoras na Educação Superior.

Teresinha de Jesus Araújo Magalhães Nogueira, Lívia Veleda de Sousa e Melo, Débora Furtado Barrera, Letícia Lopes Leite, Marcello Ferreira

DOI: $10.36229 / 978-65-86127-71-3 . C A P .03$

Capítulo 4: 0 Papel dos licenciados em computação no apoio ao ensino remoto em tempos de isolamento social devido à pandemia da COVID-19

Sidnei Renato Silveira, Cristiano Bertolini, Fábio José Parreira, Guilherme Bernardino da Cunha, Nara Martini Bigolin

DOI: $10.36229 / 978-65-86127-71-3 . C A P .04$

Capítulo 5: Categorização e análise de atividades avaliativas de um curso de Ciências Biológicas a distância. 43

Otávio Vieira Sobreira Júnior, Francisco Wagner de Sousa Paula, Lydia Dayanne Maia Pantoja, Germana Costa Paixão

DOI: $10.36229 / 978-65-86127-71-3 . C A P .05$

Capítulo 6: Artes visuais e educação: A formação de alunos de Arquitetura e Design 51

Erika Cabral Guimarães, Claudia Santos Martiniano, Isabel Dillmann Nunes

DOI: $10.36229 / 978-65-86127-71-3 . C A P .06$

Capítulo 7: Sala de Recursos Multifuncionais -SRM 61

Nilma de Paula Calado

DOI: 10.36229/978-65-86127-71-3.CAP.07 


\section{SUMÁRIO}

Capítulo 8: A atuação docente em educação física escolar: Um olhar a partir das intenções de pesquisa de publicações acadêmico-científicas 64

Adriana Flávia Neu, Eduardo Adolfo Terrazzan

DOI: $10.36229 / 978-65-86127-71-3 . C A P .08$

Capítulo 9: As aulas de educação física a partir do tema futebol: Relato de vivências no estágio supervisionado 72

Ana Gabriela Alves Medeiros, Sirlânia Souza Pereira, Geovânia Silva Mota, Marlon Messias Santana Cruz DOI: $10.36229 / 978-65-86127-71-3 . C A P .09$

Capítulo 10: Contribuições, desafios e possibilidades da prática profissional do tradutor intérprete de libras do Instituto Federal do Piauí. 78

Joaquina Maria Portela Cunha Melo, Luzia Almeida de Sousa, Tania Maria dos Santos, Delany Ramos de Sousa, Dinalva Clara Monteiro Santos Silva

DOI: $10.36229 / 978-65-86127-71-3 . C A P .10$

Capítulo 11: Relatos de experiências de leitura e escrita em sala de aula da língua portuguesa - $3^{\text {o }}$ Ano Ensino Médio. 84

Jefferson Fellipe Jahnke

DOI: 10.36229/978-65-86127-71-3.CAP.11

Capítulo 12: Letramento digital e ensino: Novas relações dialógicas e aprendizagens 90

Maria de Lourdes Rossi Remenche, Ana Paula Pinheiro da Silveira

DOI: $10.36229 / 978-65-86127-71-3 . C A P .12$

Capítulo 13: A literatura infantil como via de mão dupla: Projetos e ações efetivas do PIBID-UEMG (Subprojeto Leopoldina- MG), nos Anos Iniciais do Ensino Fundamental, de 2012 a 2017. 100

Anicézia Pereira Romanhol Bette

DOI: $10.36229 / 978-65-86127-71-3 . C A P .13$

Capítulo 14: Formação de professores e Educação do Campo: Uma análise na Escola Municipal Unidade Escolar XXXIV Miraselva (Apodi-RN)

Ana Claudia de Andrade Costa, Kyara Maria de Almeida Vieira

DOI: $10.36229 / 978-65-86127-71-3 . C A P .14$ 


\section{SUMÁRIO}

Capítulo 15: Restinga de massambaba: Importância ecológica. Utilização da fotografia na construção do saber no Ensino Fundamental 130

Lillian da Silva Oliveira, Lenilda Pereira dos Santos, Jaildo Assis da Silva

DOI: $10.36229 / 978-65-86127-71-3 . C A P .15$

Capítulo 16: Aprendizagem baseada em jogos: Experiência no ensino de física 139

Messias Vilbert de Souza Santos, Francisco Genivan Silva, Isadora Azevedo Medeiros do Nascimento, Quezia Assis de Sousa, Edicarlos Medeiros Batista

DOI: 10.36229/978-65-86127-71-3.CAP.16

Capítulo 17: 0 uso da História da Matemática na busca de uma aprendizagem significativa no ensino de Matemática.

Rodrigo Corsino Lopes

DOI: 10.36229/978-65-86127-71-3.CAP.17

Capítulo 18: Processos de transição no ensino de matemática: 0 caso da passagem do cálculo de uma a mais variáveis

Sandro René Cunha, Márcia Maria Fusaro Pinto

DOI: 10.36229/978-65-86127-71-3.CAP.18

Capítulo 19: As Olimpíadas de Matemática ampliando e fortalecendo o processo de ensino-aprendizagem

Francisco Pereira de Andrade, Aleksandre Saraiva Dantas, Walter Martins Rodrigues

DOI: $10.36229 / 978-65-86127-71-3 . C A P .19$

Capítulo 20: 0 ensino-aprendizagem de porcentagem na EJA com o uso de estratégias metacognitivas

Mariana Figueira Secafim, Marta Maria Pontin Darsie

DOI: $10.36229 / 978-65-86127-71-3 . C A P .20$ 


\section{SUMÁRIO}

Capítulo 21: Matemática e Biologia: Relatos de acessibilidade no Centro de Ciências e Planetário do Pará. 181

Sinaida Maria Vasconcelos, Rafael Silva Patrício

DOI: 10.36229/978-65-86127-71-3.CAP.21

Autores.

189 


\section{Capítulo 1}

Metodologias ativas e suas contribuições no processo de ensino-aprendizagem

Joabio Alekson Cortez Costa

Júlia Diniz de Oliveira

Denis Rodrigues Dantas

Resumo: Este trabalho debruça-se sobre a conceituação e importância das metodologias ativas no processo de ensino-aprendizagem. 0 objetivo principal é o de refletir sobre o conceito de metodologias ativas, como elas favorecem o aprendizado e quais os papéis a serem assumidos pela escola, professores e alunos. Para embasar esse estudo, recorreuse as obras de autores como: Berbel (2011), Moran (2017), Camargo (2018), Thuinie (2018) e Mattar (2017). Discute-se o protagonismo do aluno na construção do próprio conhecimento sob a mediação do professor e a necessidade de repensar as práticas pedagógicas tradicionais em favor da adoção de práticas mais centradas no estudante. Conclui-se que as metodologias ativas são importantes na medida em que mobilizam o desenvolvimento de competências e habilidades imprescindíveis para o indivíduo atuar na sociedade do século XXI.

Palavras-chave: Metodologia ativa. Ensino. Aprendizagem. Escola. 


\section{INTRODUÇÃO}

Não é novidade que o ensino assentado em práticas tradicionais, que privilegiam o protagonismo do professor em detrimento da participação ativa do aluno na construção do próprio saber, já não satisfaz as demandas de uma sociedade marcada pela crescente competividade no mercado de trabalho e que requer do indivíduo autonomia, criatividade e capacidade de gerir ou trabalhar em equipe a fim de resolver problemas e situações adversas ou adaptar-se às mudanças cada vez mais frequentes e repentinas.

Memorizar informações - que hoje são encontradas facilmente em qualquer site na rede - e repeti-las mecanicamente e acriticamente, tal qual apregoa o ensino tradicional, não promove no sujeito as habilidade e competências necessárias para atuar nesse mundo, onde as informações circulam instantaneamente e softwares realizam com mais rapidez e eficiência tarefas antes feitas exclusivamente pelos seres humanos.

Em contraponto ao ensino tradicional, teorias progressistas no campo da psicologia, da pedagogia e da sociologia emergiram no último século, destacando invariavelmente a importância da centralização do processo de ensino-aprendizagem no próprio sujeito aprendiz, partindo do pressuposto de que o ato de aprender não é uma ação externa ao indivíduo, mas envolve um processo complexo interno de construção de relações e significados, alterando constantemente as estruturas do pensamento. A interação do sujeito com o meio e a construção (e reconstrução) de significados, relações e associações dela decorrente constituiria o cerne da aprendizagem.

Essas teorias e estudos serviram de base para o desenvolvimento e implementação de metodologias ativas de aprendizagem nas instituições de ensino de diversas partes do mundo. Considerando esse contexto, o presente trabalho aborda a importância das metodologias ativas no processo de ensino-aprendizagem e os novos papéis da escola, dos professores e alunos no interior desse processo. Assim, alguns questionamentos surgiram a partir da reflexão sobre o tema e que serão respondidas no trabalho:

- $\quad 0$ que são metodologias ativas e em quais aspectos elas se diferenciam das metodologias tradicionais?

- Quais as contribuições das metodologias ativas no processo de ensino-aprendizagem e no desenvolvimento de competências e habilidades?

- Quais os perfis de professores e alunos pretendidos pelas metodologias ativas?

As metodologias ativas, como o próprio termo sugere, colocam o aluno como o sujeito ativo da sua aprendizagem, desviando o foco do professor, que passa a ser um mediador entre o aluno e o objeto do conhecimento. Segundo Moran (2017, p. 19) “Metodologias ativas são estratégias de ensino centradas na participação efetiva dos estudantes na construção do processo de aprendizagem, de forma flexível, interligada e híbrida".

Investigar-se-á, portanto, a importância da utilização de metodologias ativas no processo de ensinoaprendizagem e os novos papéis a serem assumidos pelos professores e alunos. Com vistas a alcançar esse objetivo, utilizou-se como recurso metodológico, a pesquisa bibliográfica, buscando-se a leitura de livros e artigos de autores cujas ideias são importantes contribuições para discussão da temática em tela, entre eles: Berbel (2011), Moran (2017), Camargo (2018), Thuinie (2018) e Mattar (2017).

\section{METODOLOGIAS ATIVAS COMO CAMINHO PARA DESPERTAR A CRIATIVIDADE, A AUTONOMIA E A COLABORAÇÃO NO PROCESSO DE ENSINO-APRENDIZAGEM}

Pensar a educação nos dias atuais requer considerar que vivemos na chamada "era do conhecimento", como nos aponta Gadotti (2000, p. 7). Nessa nova era, o conhecimento está cada vez mais acessível graças aos avanços na informática e nos meios de telecomunicações ocorridos a partir de meados do último século. Verifica-se uma relativa democratização do conhecimento, pois como atenta o autor, boa parte da população ainda não tem acesso aos meios tecnológicos necessários para acessá-lo. Ainda segundo ele, uma imensa quantidade dos dados que circulam nas redes é na verdade informação pronta e acabada e não conhecimento. Dessa forma, com poucos cliques podemos acessar uma gama de informações que estão armazenadas em gigantescos bancos de dados, mas não necessariamente utilizam-na para a geração de conhecimento.

Cabe então refletir sobre o papel da escola, principalmente, porque hoje "(...) As novas tecnologias criaram novos espaços do conhecimento" (GADOTTI, 2000, p. 7, grifo do autor). 0 indivíduo hoje não aprende 
somente na escola, mas também em casa, nas igrejas, centros comunitários, museus, parques ecológicos, ONGs, associações, etc.

Não à toa, os cursos à distância vêm se configurando como meios de formação importantes, dados o conforto de estudar em casa, a flexibilidade de horários, a diminuição dos custos e a facilidade de acesso, desde que se disponha de um computador ou outro equipamento (tablete, notebook, smartphone) e internet de qualidade.

O ciberespaço rompeu com a ideia de tempo próprio para a aprendizagem. Não há tempo e espaço próprios para a aprendizagem. Como ele está todo o tempo em todo lugar, o espaço da aprendizagem é aqui - em qualquer lugar - e o tempo de aprender é hoje e sempre (GADOTTI, 2000, p. 8).

Nesse cenário, é preciso refletir sobre as novas funções da escola, principalmente, quando a memorização e repetição de informações - marcas do ensino tradicional - se tornaram praticamente obsoletas frentes à facilidade de acesso a estas e às novas demandas da sociedade. Atualmente, espera-se que os indivíduos sejam autônomos, criativos, tenham capacidade de agir individualmente e coletivamente na resolução de problemas e desafios, dominem as novas tecnologias, estejam conscientes da necessidade de aprender e aperfeiçoarem-se em seus campos de trabalho, tendo disposição de buscar cursos de formação continuadas, workshops e feiras. Cultivem um senso de disciplina e responsabilidade, e trabalhem em prol do bem estar da coletividade. Nesse sentido, a tarefa da escola é educar os indivíduos visando o estímulo ao desenvolvimento de habilidade e competências. Antunes (2014) resume a função da escola ao afirmar que:

Como educar não significa apenas transmitir apenas o legado cultural às novas gerações, mas também ajudar o aluno a aprender o aprender, despertar vocações, proporcionar condições para que cada um alcance o máximo de sua potencialidade e, finalmente, permitir que cada um conheça suas finalidades e tenha competências para mobilizar meios para concretizá-las, chega-se ao sentido estrutural da questão: o que significa educar. Em síntese: aprender a conhecer, fazer, viver junto e aprender a ser (ANTUNES, 2014, p. 45).

Decerto, as metodologias tradicionais, assentadas na transmissão do conhecimento pelo professor cabendo ao aluno apenas a assimilação do que foi transmitido e sua repetição mecânica e acrítica em testes homogêneos e padronizados, são incapazes sozinhas de promover o desenvolvimento das habilidades e competências cognitivas, intrapessoais e interpessoais requeridas pela educação do século XXI. Infelizmente, por razões que vão desde a formação deficitária e a desvalorização social e econômica dos professores, passando pela falta de recursos didáticos e tecnológicos nas escolas até a pouca efetividade das políticas públicas na área de educação, o ensino tradicional ainda prevalece na maioria das escolas brasileiras.

Mesmo diante de tantos avanços tecnológicos e científicos, o modelo de aula continua predominantemente oral e escrito, assim como os recursos utilizados. Nesse contexto, têm-se mantido intacto muito giz, caderno e caneta. Quando mudam, ganham uma nova roupagem por meio da utilização de instrumentos audiovisuais, como a inserção de filmes, vídeos e apresentações gráficas e projetores multimídia. Já os alunos continuam a receber passivamente e cada vez mais esperam tudo produzidos pelos professores (DAROS, 2018, p. 3).

Nesse sentido, concorda-se com Daros (2018) que preconiza a necessidade de mudar as práticas e elaborar estratégias que aproximem o objeto de conhecimento com a realidade do sujeito e promovam um aprendizado interativo. Segundo ele, a inovação constitui o cerne dessa mudança e deve estar assentada em dois elementos essenciais: a criatividade e a produção de novas ideias. Todavia, nos alerta para a intencionalidade subjacente a qualquer prática educativa e a imprescindibilidade do planejamento e da sistematização, estando evidentes para aquele que a elabora a função social da escola e da universidade, a finalidade do que se ensina e os resultados que se pretende alcançar a partir de suas práticas. Por fim, é preciso considerar "os diversos fatores que contribuem para a configuração de um processo inovador, implicando a criatividade dos sujeitos, a motivação para efetivar as ideias, o conhecimento e os recursos materiais possíveis" (DAROS, 2018, p. 5).

Não se defende neste trabalho a extinção das metodologias tradicionais de ensino, mas sim a adoção de metodologias que rompam com a passividade do aluno e estimulem a sua participação ativa na construção do saber, as chamadas metodologias ativas. Por metodologia entendem-se as “(...) grandes diretrizes que 
orientam os processos de ensino e aprendizagem e que se concretizam em estratégias, abordagens e técnicas concretas, específicas e diferenciadas" (MORAN, 2017, p. 19).

As metodologias ativas, por sua vez, são aquelas que estimulam a participação do aluno no processo de construção do seu conhecimento, requerendo, portanto, o desenvolvimento de habilidades e competências necessárias para a aquisição do saber. Muda-se o paradigma do aluno visto apenas como repositório de informações transmitidas pelo professor para aquele que, por meio de estratégias ativas de aprendizagens, é capaz de construir seu próprio conhecimento, dando-lhe significados, relacionando-o à sua realidade e aplicando-o na resolução de problemas e desafios do cotidiano, seja ele no âmbito da escola, do trabalho, da sua casa e no exercício de sua cidadania.

Apesar do conceito de metodologia ativa ser relativamente novo, a discussão em torno da aprendizagem centrada no aluno não é novidade, como esclarece Mattar (2017, p. 17). Os fundamentos teóricos e conceituais que subsidiam essas metodologias começaram a ser elaborados no início do século XX, a partir dos trabalhos de John Dewey, Kilpatrick, Decroly, Ausubel e de Paulo Freire, para citar um brasileiro, entre outros. De acordo com Daros (2018), as teorias criadas por esses autores e posteriormente reinterpretadas tiveram significativas repercussões no campo da Pedagogia, pois deram:

[...] subsídios para uma pedagogia dinâmica, centrada na criatividade e na atividade discente, em uma perspectiva de construção do conhecimento, do protagonismo, do autodidatismo, da capacidade de resolução de problemas, do desenvolvimento de projetos, da autonomia e do engajamento no processo de ensino-aprendizagem por meio das metodologias de abordagem ativa (DAROS, 2018, p. 9).

As metodologias ativas consideram o tempo de aprendizagem, as habilidades e competências já alcançadas e o conhecimento prévio de cada aluno, elementos fundamentais para a construção e assimilação de novos conhecimentos; promovem a interdisciplinaridade e transdisciplinaridade, de modo a possibilitar a ampliar a capacidade de análise dos estudantes sobre determinadas situações ou eventos e de resolução de problemas e desafios; e propõem modelos híbridos de ensino, que unem as vantagens do ensino presencial com os benefícios do ensino a distância. De acordo com Valente; Almeida; Gerald (2017), as metodologias ativas podem ser assim definidas:

[...] estratégias pedagógicas para criar oportunidades de ensino nas quais os alunos passam a ter um comportamento mais ativo, envolvendo-os de modo que eles sejam mais engajados, realizando atividades que possam auxiliar o estabelecimento de relações com o contexto, o desenvolvimento de estratégias cognitivas e o processo de construção de conhecimento (VALENTE; ALMEIDA; GERALD, 2017, p. 464).

Ao discorrer sobre as vantagens das metodologias ativas, Camargo (2018, p. 16) elenca as seguintes: estímulo ao desenvolvimento das competências necessárias para o mercado de trabalho e a vida pessoal; construção do conhecimento numa perspectiva transdisciplinar; fomento ao empreendedorismo; mudança dos papéis do professor e do aluno; e a construção de ideias e conhecimentos e o estímulo à reflexão.

Vantagens das metodologias ativas também são apontadas por Berbel (2011). Segundo a autora, essas metodologias favorecem o desenvolvimento da autonomia, qualidade essencial para a obtenção de resultados significativos na aprendizagem, pois repercute diretamente no nível de motivação e engajamento, no desenvolvimento pessoal, na aprendizagem, no desempenho nas avaliações e no estado psicológico do indivíduo. Nesse sentido as metodologias ativas auxiliam o aluno a se perceber enquanto agente importante no próprio aprendizado, condição essencial para a sua motivação nas atividades escolares e na busca do conhecimento.

A implementação dessas metodologias pode vir a favorecer uma motivação autônoma quando incluir o fortalecimento da percepção do aluno de ser origem da própria ação, ao serem apresentadas oportunidades de problematização de situações envolvidas na programação escolar, de escolha de aspectos dos conteúdos de estudo, de caminhos possíveis para o desenvolvimento de respostas ou soluções para os problemas que se apresentam alternativas criativas para a conclusão do estudo ou da pesquisa, entre outras possibilidades (BERBEL, 2011, p.28). 
A despeito do enorme potencial das metodologias ativas no campo da educação, sua real efetivação na escola depende em grande parte do interesse dos professores, dos alunos e da comunidade escolar em relação às potencialidades dessas formas de ensinar e aprender.

Para que as Metodologias Ativas possam causar um efeito na direção da intencionalidade pela qual são definidas ou eleitas, será necessário que os participantes do processo as assimilem, no sentido de compreendê-las, acreditem em seu potencial pedagógico e incluam uma boa dose de disponibilidade intelectual e afetiva (valorização) para trabalharem conforme a proposta, já que são muitas as condições do próprio professor, dos alunos e do cotidiano escolar que podem dificultar ou mesmo impedir esse intento (BERBEL, 2011, p.37).

Diante da citação da autora, cabe refletir em torno do seguinte questionamento: como a escola, o corpo docente e os estudantes devem agir para que as metodologias ativas realmente ganhem terreno nas práticas educativas desenvolvidas na instituição? As respostas são muitas, mas todas perpassam pela necessidade de questionar os velhos métodos de ensino tradicionais e as próprias concepções de educação e da função social da escola.

Antes de tudo é preciso repensar a estrutura e o funcionamento da escola. Não há como iniciar o trabalho com metodologias ativas se a instituição mostra-se inflexível e resistente quanto ao trabalho interdisciplinar, às mudanças de horários, do currículo e das práticas pedagógicas, à readaptação dos espaços, à proposição de formas de avaliação para além de testes escritos, ao diálogo aberto com os professores, alunos e pais, e à busca de parcerias externas favorecendo o trabalho em rede. É condição primordial então uma gestão democrática, capaz de mobilizar os diferentes atores em torno de um objetivo comum, mediando conflitos e interesses para chegar a soluções. Ademais, como o ambiente físico da escola interfere diretamente nas práticas educativas, a melhoria da infraestrutura e a readequação dos espaços coloca-se como um tópico importante, como defende Moran (2015):

0 ambiente físico das salas de aula e da escola como um todo também precisa ser redesenhado dentro dessa nova concepção mais ativa, mais centrada no aluno. As salas de aula podem ser mais multifuncionais, que combinem facilmente atividades de grupo, de plenário e individuais. Os ambientes precisam estar conectados em redes sem fio, para uso de tecnologias móveis, o que implica ter uma banda larga que suporte conexões simultâneas necessárias (MORAN, 2015, p. 19).

No tocante aos professores, é crucial que estejam abertos as mudanças, por vezes radicais, na forma como pensam o planejamento, a didática, a organização da sala de aula, a avaliação e as próprias concepções de educação e escola. Assim, o primeiro passo é a formação do corpo docente, com o intuito de sensibilizá-lo sobre a importância do protagonismo do estudante e prepara-lo para o uso de metodologias ativas. Esse trabalho de formação é fundamental, haja vista que a maioria dos professores não conhece ou não se sente seguro em trabalhar com elas.

O papel principal do professor passa a ser o de mediador/problematizador/facilitador da aprendizagem, cabendo-lhe o planejamento dos percursos individuais e coletivos a serem trilhados pelos alunos, a elaboração de atividades desafiadoras e estimulantes (situações-problemas, projetos, jogos, experimentos, aulas de campo, etc.) que mobilizem as habilidades e competências que se pretende desenvolver, a organização dos espaços físicos onde ocorrerão as aulas, a escolha dos materiais e recursos tecnológicos a serem utilizados, a gestão do tempo, prevendo momentos de estudo individuais e coletivos, e a escolha da melhor forma de avaliação de acordo com as características da turma e do aluno. Espera-se também do professor uma maior proximidade com o aluno, a fim de motivá-lo a dar o melhor de si, explorar ao máximo suas habilidades e conscientizá-lo sobre a importância do compromisso, da disciplina e da responsabilidade para concretizar as metas e objetivos.

Trabalhar com metodologias ativas requer muito esforço e dedicação, pois exige do professor o domínio de competências ligadas não só ao âmbito profissional, mas também ao campo socioemocional (criatividade, responsabilidade, capacidade de gerir situações de conflito, resiliência, autogestão, disciplina, empatia, paciência, etc.). 
Porém não apenas o professor deve ter uma postura diferenciada quando se trata do trabalho com metodologias ativas, o aluno também precisa assumir um novo papel: o de protagonista da própria aprendizagem, o que pode ser bem difícil no começo, haja vista que muitos estão acostumados a receber o conhecimento pronto e acabado pelo professor ou disponível nos livros didáticos. Diante das novas demandas impostas pelo mercado de trabalho e a sociedade no século XXI, espera-se que os indivíduos desenvolvam novas competências e habilidades necessárias para seu exercício na vida social e profissional. Assim, a escola que se mantém presa às práticas tradicionais, que foram úteis em outro contexto e momento histórico, não consegue preparar competentemente indivíduos para sobreviver nesse novo mundo, pois como contextualiza Berbel:

A complexidade crescente dos diversos setores da vida no âmbito mundial, nacional e local tem demandado o desenvolvimento de capacidades humanas de pensar, sentir e agir de modo cada vez mais amplo e profundo, comprometido com as questões do entorno em que se vive (BERBEL, 2011, p.25-26).

Assim, a escola precisa garantir aos alunos espaços de aprendizagem diferenciados e mobilizar a equipe docente e pedagógica no sentido de desenvolver um trabalho assentado em múltiplas estratégias de ensino que motivem os alunos a se engajarem na construção do seu conhecimento, tanto individualmente como em grupos, explorem ao máximo seus potenciais e não tenham receio de errar e recomeçar novamente, traçando outros percursos, revendo ideias e atitudes e projetando novos horizontes. Nesse sentido, Valente (2017) esclarece que:

Em vez do ensino baseado na transmissão de informação, da instrução bancária, como criticou Paulo Freire (1970), na metodologia ativa, o aluno assume uma postura mais participativa, na qual ele resolve problemas, desenvolve projetos e, com isso, cria oportunidades para a construção de conhecimento (VALENTE, 2017, p. 43).

Verifica-se, portanto, que implementar metodologias ativas não é tarefa fácil, pois exige um grande esforço de sensibilização e mobilização das várias partes integrantes da instituição de ensino e requer um planejamento cuidadoso, sistemático e intencional das atividades, prevendo momentos de estudo individualizados, em grupos e sob a tutoria do profissional e a utilização de materiais e recursos didáticos diversos. A avaliação também precisa ser repensada, estando presente ao longo de todo o processo de ensino, a fim de identificar os avanços e os obstáculos que precisam ser superados, dando suporte e direcionamentes para a elaboração de novas estratégias.

\section{CONSIDERAÇÕES FINAIS}

As metodologias ativas têm ganhado cada vez mais importância e relevância no interior das instituições de ensino e sendo objeto de estudos acadêmicos no âmbito da Pedagogia, dos cursos de licenciatura e áreas afins. Apesar das discussões estarem ganhando mais ênfase nas últimas décadas, os seus fundamentos teóricos começaram a ser formulados no início do século XX. Hoje, as instituições de ensino que não procurarem incorporar essas metodologias nas práticas pedagógicas correm o risco de ficarem ultrapassadas e não conseguirem formar um indivíduo com competências e habilidades cognitivas e socioemocionais necessárias para atuar na sociedade do século XXI.

As vantagens das metodologias ativas são várias: a maior motivação dos alunos pelos estudos, o desenvolvimento de atitudes, habilidades e competências significativas, a ampliação do aprendizado e o estímulo ao pensamento crítico e autônomo. Ademais, elas mobilizam o estudante no processo de construção do próprio aprendizado, por meio da mediação do professor, cuja função passa a ser de orientador, tutor e problematizador.

Obviamente, o trabalho com essas estratégias não e fácil e requer um esforço conjunto da gestão escolar, apoio pedagógico, professores e alunos. Mudanças se fazem necessárias, desde adaptações e melhorias na estrutura física das escolas, flexibilização de horários, formação de professores e um trabalho intensivo com os alunos, visando adaptá-los a essa forma de aprender.

A partir do desenvolvimento do trabalho, fica evidente o quanto as metodologias ativas podem contribuir na formação humana e profissional dos alunos, pois seu foco é o desenvolvimento de habilidades e competências que lhes permitam agir com criatividade, autonomia e de forma colaborativa, preparando-os para a vivência em um mundo no qual a produção e o domínio do conhecimento são fundamentais para a emancipação do sujeito. 


\section{AGRADECIMENTOS}

À Coordenação de Aperfeiçoamento de Pessoal em Nível Superior (Capes) pelo financiamento desta pesquisa junto ao programa de Pós-graduação e Pesquisa em Geografia.

\section{REFERÊNCIAS}

[1] ANTUNES, Celso. Professores e professauros: Reflexões sobre a aula e práticas pedagógicas diversas. 9. ed. Petrópolis, Rj: Vozes, 2014.

[2] BERBEL, Neusi Aparecida Navas. As metodologias ativas e a promoção da autonomia de estudantes. Semina: Ciências Sociais e Humanas, Londrina, v. 32, n. 1, p.25-40, jan./jun. 2011.

[3] CAMARGO, Fausto. Por que usar metodologias ativas de aprendizagem. In: CAMARGO, Fausto; DAROS, Thuinie. A sala de aula inovadora: estratégias pedagógicas para fomentar o aprendizado ativo. Porto Alegre: Penso, 2018. p. 13-17. (Desafios da Educação).

[4] Metodologias ativas: aspectos históricos e desafios atuais. In: CAMARGO, Fausto; DAROS, Thuinie. A sala de aula inovadora: estratégias pedagógicas para fomentar o aprendizado ativo. Porto Alegre: Penso, 2018. p. 8-12. (Desafios da Educação).

[5] DAROS, Thuinie. Por que inovar na educação? In: CAMARGO, Fausto; DAROS, Thuinie. A sala de aula inovadora: estratégias pedagógicas para fomentar o aprendizado ativo. Porto Alegre: Penso, 2018. p. 3-7. (Desafios da Educação).

[6] GADOTTI, Moacir. Perspectivas atuais da educação. São Paulo em Perspectiva, São Paulo, v. 14, n. 2, p.3-11, jun. 2000.

[7] MATTAR, João. Metodologias Ativas: para a educação presencial, blended e a distância. São Paulo: Artesanato Educacional, 2017.

[8] MORAN, José. Metodologias ativas para uma aprendizagem mais profunda. In: BACICH, Lilian; MORAN, José (org.). Metodologias ativas para uma educação inovadora: uma abordagem teórico-prática. Porto Alegre: Penso, 2017. p. 16-42.

[9] MORÁN, José. Mudando a educação com metodologias ativas. In: SOUZA, Carlos Alberto de; MORALES, Ofelia Elisa Torres. Convergências Midiáticas, Educação e Cidadania: aproximações jovens. Ponta Grossa: Pg: Foca Fotoproex/uepg, 2015. p. 15-33. (Coleção Mídias Contemporâneas). Disponível em: <http://www2.eca.usp.br/moran/wpcontent/uploads/2013/12/mudando_moran.pdf>. Acesso em: 21 jan. 2020.

[10] VALENTE, José Armando. A sala de aula invertida e a possibilidade do ensino personalizado: uma experiência com a graduação em midialogia. In: BACICH, Lilian; MORAN, José (org.). Metodologias ativas para uma educação inovadora: uma abordagem teórico-prática. Porto Alegre: Penso, 2017. p. 43-61.

[11] VALENTE, José Armando; ALMEIDA, Maria Elizabeth Bianconcini de; GERALD, Alexandra Fogli Serpa. Metodologias ativas: das concepções às práticas em distintos níveis de ensino. Revista Diálogo Educacional, Curitiba, v. 17, n. 52, p.455-478, abr./jun. 2017. 


\title{
Capítulo 2
}

\section{Mapas conceituais como elementos provedores de ensino- aprendizagem numa perspectiva construtivista sociointeracionista}

\author{
Mayara Lopes de Freitas Lima
}

Alberes Lopes de Lima

Resumo: Tendo em vista que as tecnologias de informação e comunicação são recursos didáticos substancialmente significativos, sua utilização é indispensável num processo educacional que pretende ir além dos muros da escola. Desse modo, propõe-se no presente trabalho a utilização no cotidiano escolar de mapas conceituais. Particularmente, trabalha-se com mapas conceituais produzidos com o auxílio do Cmap Tools. Sua manipulação por parte de alunos e professores ilustra bem o letramento digital necessário à formação do estudante do século XXI. Em síntese, a presente pesquisa tem por objetivo geral discutir a utilização desse software no planejamento de aulas e como elemento provedor do processo de ensino-aprendizagem. Parte-se do referencial teórico associado ao modelo VM proposto por Moretto, baseado numa perspectiva Epistemológica Construtivista Sociointeracionista. O modelo VM é construído a partir de cinco componentes relacionados logicamente. No presente estudo, destaca-se o componente Linguagens, com ênfase no letramento digital. Na presente pesquisa empírica, a utilização do Cmap Tools na confecção de mapas conceituais ocorre em aulas de Física. Além de servirem como esquemas, planos de aula ou de revisão, os mapas permitem também fazer o levantamento prévio dos conhecimentos dos discentes em relação ao conteúdo abordado. Objetivando o domínio do letramento digital por parte dos discentes, estes foram também motivados a construírem seus próprios mapas conceituais, utilizando o Cmap Tools. Utiliza-se como exemplos de representação através de mapas conceituais os conteúdos Gravitação universal, Campo elétrico, Calor e temperatura. Convém destacar que não há um único mapa conceitual para abordar determinado tema. Sendo assim, os discentes foram estimulados a construir seus próprios mapas conceituais. Como resultado da prática utilizada, percebeu-se que essa ação faz com que os alunos revisem o conteúdo, vejam outras formas de abordá-lo e percebam que várias soluções são igualmente válidas para representar o conteúdo em mapas conceituais. Verifica-se também que, com o domínio do instrumento pelo discente, a complexidade dos mapas conceituais se acentua e eles ficam cada vez mais reflexivos. Conclui-se que os mapas conceituais, de acordo com a prática desenvolvida cumprem um papel fundamental no processo ensino-aprendizagem no que se refere ao domínio da linguagem científica. 0 uso do Cmap Tools na confecção desses mapas contribui também para o domínio do letramento digital por parte dos discentes. Quando os discentes constroem seus próprios mapas é possível compará-los, verificando-se que a argumentação e a contra-argumentação permite que os alunos construam e reconstruam o significado dos conceitos. Como a imagem visual tem efeito significativo em nossa memória, pode-se verificar que, com a construção dos mapas conceituais, os discentes, além de compreenderem melhor o conteúdo, ficam mais atentos aos conceitos fundamentais, o que comprova a capacidade desses mapas em atuar como um importante elemento provedor de ensino-aprendizagem.

Palavras-chave: Mapas conceituais, Epistemologia do professor, Letramento digital. 


\section{INTRODUÇÃO}

Alguns educadores podem até se sentir apreensivos ou inseguros diante do desafio de novas tecnologias. Esse sentimento, entretanto, não merece nenhuma repreensão, posto que até mesmo o filósofo Sócrates (470 a. C. - 399 a.C.) demonstrou desconfiança com uma tecnologia hoje bem usual, a escrita. Ele afirmava que escrever "criaria esquecimento nas almas", por esta razão ele não deixou registros de suas palavras nem de seu trabalho (FADEL; BILIAK; TRILLING, 2015, p. 27).

Não podemos dizer que Sócrates estivesse totalmente errado, uma vez que nossa capacidade de memorização fica aquém daquela de pessoas que, por exemplo, memorizavam livros inteiros, conforme Bradbury sonhou reviver na ficção Fahrenheit 451 (BRADBURY, 2003). No entanto, se por um lado nossa capacidade de memorização diminuiu significativamente, por outro, desenvolvemos uma construção coletiva com a escrita que nos permite rever, ampliar e corrigir a qualquer momento um trabalho.

Logo, preocupações com o impacto tecnológico não é assunto recente. Atualmente, vivemos situações semelhantes com relação às novas Tecnologias de Informação e Comunicação (TICs). De fato, o uso exagerado e/ou inadequado tem levado a situações de dependência, falta de socialização, obesidade, problemas de coluna, distúrbios psicológicos, dentre outros. Todavia, é inegável que as TICs possuem aspectos positivos importantes, inclusive no contexto educacional. Jogos podem ser realizados incluindo colaboração ao vivo e interagindo com o mundo real, a internet permite um amplo acesso à informação e, consequentemente, também à construção do conhecimento, diversos softwares educacionais tem tornado a aprendizagem mais acessível, os cursos de EAD têm sua oferta ampliada a cada ano que passa.

0 fato é que na realidade de um ensino por competências e habilidades, não podemos ficar à margem da evolução tecnológica. Porém, considerando que a escola deve prover o aluno de meta-aprendizado e caráter, além de conhecimentos e habilidades, devemos promover uma educação crítica e reflexiva que permita ao aluno um crescimento consciente, íntegro, respeitando seus semelhantes, respeitando a natureza e tendo uma formação cidadã capaz de contribuir com a criação de um mundo melhor.

Levando em consideração esse paradigma da educação num mundo em transformação, Moretto (2014) criou um modelo pedagógico com a finalidade de auxiliar a prática docente. Seu modelo baseou-se numa perspectiva Epistemológica Construtivista Sociointeracionista, denominado modelo VM, apresenta-se associado a cinco componentes que se relacionam logicamente, conforme figura 1.

No presente estudo, destacamos o componente Linguagens, pois a cada situação complexa corresponde uma linguagem própria, adequada aos conteúdos conceituais que a ela se relacionam (MORETTO, 2014, p. 86). Esse conceito tem relevância desde os trabalhos de Vygotsky, nos quais ele considera que a mesma é responsável pela estrutura do pensamento da criança. Moretto (2014, p. 87) parte do princípio de que "nenhuma palavra tem sentido em si mesma, quem lhe dá o sentido é o contexto em que é utilizada". Então, nesse sentido, cai por terra aquela ideia de que a mente do aluno é uma tábula rasa e a ideia de educação "bancária", tão questionada por Freire (2014) e Giroux (1983).

Em seu cotidiano as crianças possuem uma linguagem do senso comum (doxologia) que na escola é acrescida pela linguagem científica (epistemológica). Desse modo, em sala de aula, a epistemologia do professor é refletida na aula, em que ocorre a transposição de uma linguagem a outra. Detalhes acerca dessa relação podem ser encontrados com mais profundidade na obra de Moretto (2014). 0 que desejamos destacar é que as palavras não têm sentido em si mesmas, mas o que lhes dá o sentido é o contexto no qual as mesmas estão inseridas. Logo, a linguagem exerce papel fundamental no processo de construção do conhecimento.

Num mundo globalizado, em que há tendências de desenvolvimento de várias tecnologias e inovações, como computadores quânticos, novas mídias, robótica avançada, veículos autônomos e materiais avançados, os discentes precisam atingir várias competências para atingir o sucesso no século XXI. Fadel, Biliak e Trilling (2015) destacam quatro dimensões para a Educação do futuro: conhecimento, habilidades, caráter e meta-aprendizado.

Dentre essas quatro dimensões da educação, igualmente relevantes, discutiremos a dimensão do conhecimento. Dentre outros aspectos, percebemos que a disseminação de máquinas inteligentes tem levado a um aumento na automação dos empregos, o que causa mudanças significativas na força de trabalho e instabilidades econômicas, que se refletem em desigualdades econômicas de renda e emprego (FADEL; BILIAK; TRILLING, 2015, p. 85). 
Figura 1- Esquematização do Modelo VM

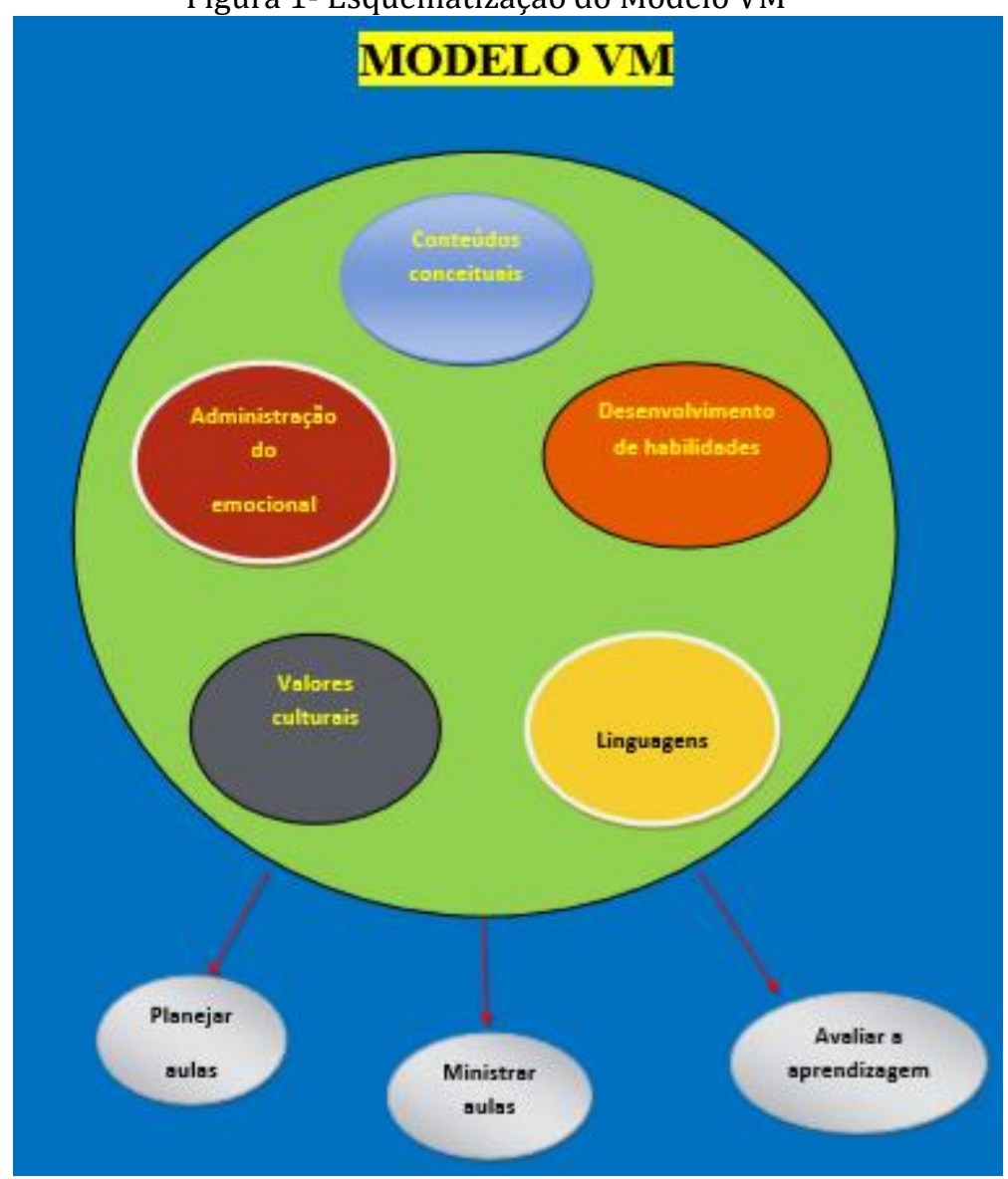

Fonte: elaborado a partir de Moretto (2014)

Isto nos induz a concluir que o ser humano deve ser eficiente no domínio no qual a máquina não é capaz de substituí-lo: síntese, criatividade, capacidade de agir em situações complexas, por exemplo. Todavia, para tal o homem deve aceitar a tarefa de dominar os conhecimentos tecnológicos, ter a mente aberta para inovações e, principalmente, familiarizar-se com as ferramentas tecnológicas (internet, processadores de textos, planilhas eletrônicas, aplicativos de mídias sociais). Logo, é necessário que o estudante do século XXI domine a Linguagem tecnológica, como ferramenta essencial para ter acesso ao avanço tecnológico que na modernidade se apresenta.

Com esse espírito, propomos no presente trabalho a utilização no cotidiano escolar de mapas conceituais. Embora eles não tenham se constituído em algo tão recente, pois há mais de vinte anos estão à disposição dos educadores (exemplos de sua utilização podem ser vistos em diversos trabalhos, como os de Martins, Verdeaux e Sousa (2009) e de Nogueira e De Souza (2019)), o diferencial do presente trabalho reside no fato de que sugerimos o apoio tecnológico como elemento capaz de torná-lo mais atraente e motivador para o discente. Particularmente, trabalharemos com mapas conceituais produzidos com o auxílio do software Cmap Tools. Sua manipulação por parte de alunos e professores ilustra bem o letramento digital necessário á formação do estudante do século XXI. Quanto mais próxima sua formação estiver das novas tecnologias, melhor preparado ele estará para enfrentar os desafios de uma educação em nível global.

Desse modo, a presente pesquisa teve por objetivo geral discutir a utilização do software Cmap Tools no planejamento de aulas e como elemento provedor do processo de ensino-aprendizagem. Sua aplicabilidade ocorreu em uma escola de ensino médio da rede federal de educação, sediada em Recife (PE). Tendo em vista que as tecnologias de informação e comunicação são recursos didáticos substancialmente significativos, possibilitando uma difusão maior de ideias, sua utilização é indispensável num processo educacional que pretende ir além dos muros da escola. 


\section{METODOLOGIA}

Em nossa pesquisa empírica, utilizamos o software Cmap Tools na confecção de mapas conceituais que foram utilizados em aulas de Física. Além de servirem como esquemas, planos de aula ou de revisão, os mapas permitiram também fazer o levantamento prévio dos conhecimentos dos discentes em relação ao conteúdo abordado.

Objetivando o domínio da linguagem digital por parte dos discentes, eles foram também motivados a construírem seus próprios mapas conceituais, utilizando o software Cmap Tools. Desse modo, ao mesmo tempo em que os discentes revisam os conceitos relacionados ao que estão estudando, aprendem a utilizar ferramentas digitais, aproximando-se das competências que devem desenvolver e das habilidades que necessitam dominar.

\section{RESULTADOS E DISCUSSÕES}

Os mapas conceituais têm por objetivo representar relações significativas entre conceitos na forma de proposições. Segundo Novak e Gowin (1996, p. 31), "na sua forma mais simples, um mapa de conceitos consta apenas de dois conceitos unidos por uma palavra de ligação de modo a formar uma proposição" Assim, quando dizemos que "água é vida", estamos usando a representação de um mapa conceitual. Com exceções de alguns conceitos primitivos ou descobertos pela criança em sua mais tenra idade, a maior parte dos significados dos conceitos são aprendidos através da composição de proposições em que se inclui o conceito a ser adquirido.

Diversos pesquisadores se debruçaram ao longo das duas últimas décadas diante do tema de mapas conceituais como elementos provedores de ensino-aprendizagem. Com a intenção de citar alguns desses trabalhos, destacamos Almeida e Moreira (2008) que investigaram as dificuldades de estudantes de graduação em Física na aprendizagem de conceitos de óptica física, envolvendo concepções alternativas e a utilização de mapas conceituais como instrumento didático para facilitar a aprendizagem significativa desses conceitos.

Convém notar que, nesse caso, eles tiveram como pressuposto teórico a aprendizagem significativa à luz dos trabalhos de Ausubel. De acordo com esse referencial teórico, os Almeida e Moreira (2008, p. 4403-2) sintetizam que, para que ocorra a aprendizagem significativa é preciso que:

a) o material, contendo as novas informações a serem aprendidas, deve ser potencialmente significativo. Isso significa que esse material possa ser relacionável à estrutura cognitiva do aprendiz de maneira não-arbitrária e substantiva (não-literal);

b) o aluno deve manifestar uma pré-disposição para aprender. Se não houver uma pré-disposição para a aprendizagem, provavelmente, o aluno apenas usará o método da memorização sem significado, o que caracteriza, de acordo com Ausubel, a aprendizagem mecânica (ou automática).

Voltando à discussão, podemos afirmar, de modo mais objetivo, que nosso conhecimento relacionado a mapas conceituais os relaciona a esquemas utilizados na representação de um conjunto de significados conceituais que se correlacionam formando proposições. Desse modo, utilizando mapas conceituais fica mais claro tanto para professores como para os alunos, "o pequeno número de ideias chave em que eles se devem focar para uma tarefa de aprendizagem específica" (NOVAK; GOWIN, 1996, p. 31). Diante disto, começamos nossa prática com modelos mais simples, apenas interligando alguns conceitos relacionados ao conteúdo.

O primeiro exemplo de representação através de mapas conceituais que apresentamos refere-se a um conteúdo programático do $3^{\circ}$. ano do ensino médio que todos estudam: Campo elétrico. Esse mapa pode ser visto na figura 2 . 
Figura 2 - Mapa conceitual referente ao conteúdo Campo elétrico

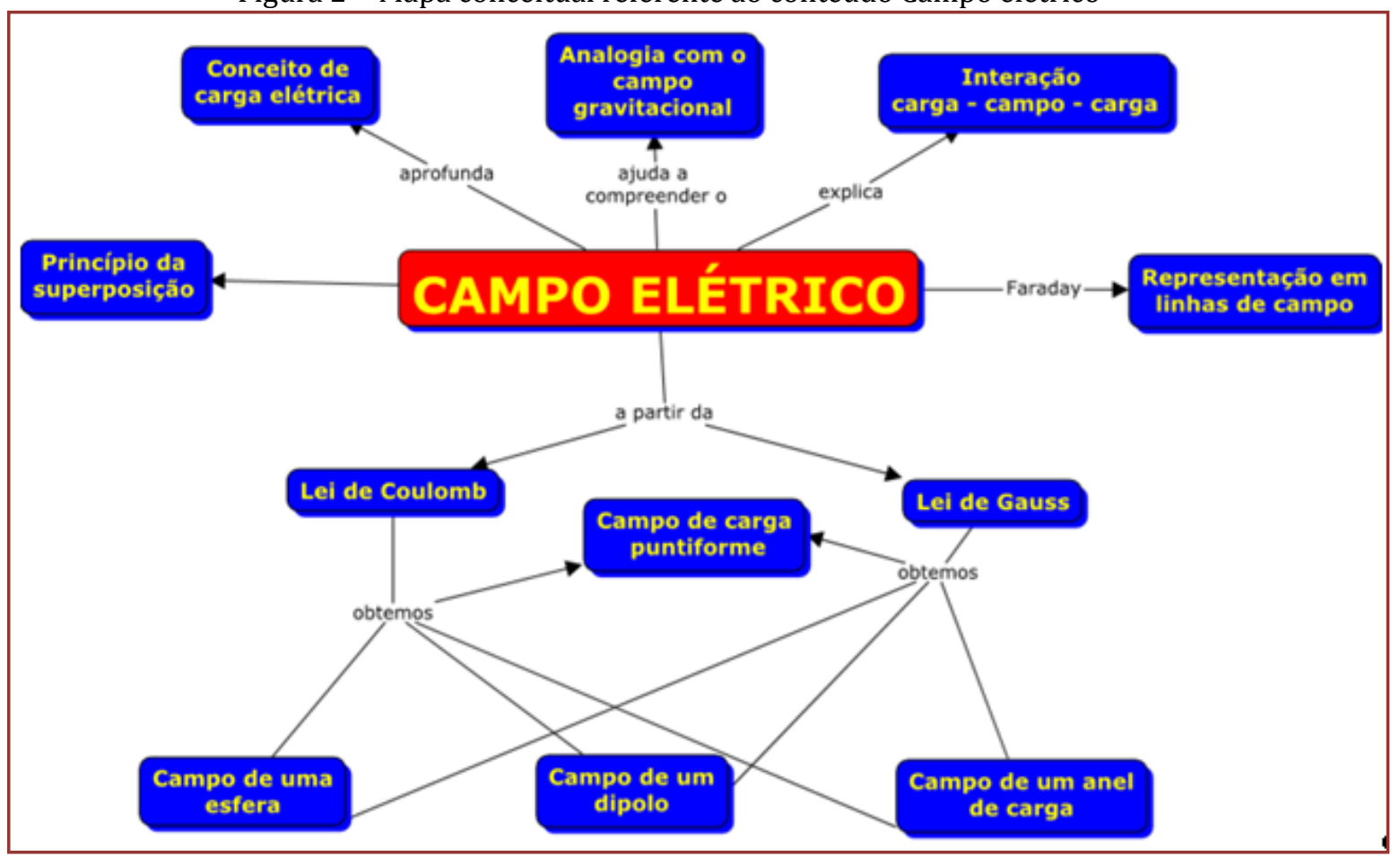

Fonte: elaborado pelos autores

Convém destacar que não há um único mapa conceitual para abordar determinado tema. Sendo assim, os discentes foram estimulados a construir seus próprios mapas conceituais. Essa ação faz com que os alunos revisem o conteúdo, vejam outras formas de abordá-lo e perceber que várias soluções são igualmente válidas para representar o conteúdo em mapas conceituais. Particularmente, com relação a esse mapa conceitual específico (Campo elétrico), os discentes, na maioria das vezes, construíram mapas com mais detalhes explicitando os termos utilizados na representação. Isto concorda plenamente com Novak e Gowin (1996, p. 33), quando afirmam que:

Os estudantes e os professores fazem notar frequentemente, durante a elaboração de mapas conceptuais, que reconhecem novas relações e portanto novos significados (ou pelo menos significados que eles não possuíam conscientemente antes de elaborarem o mapa). Neste sentido, a elaboração de mapas de conceitos pode ser uma actividade criativa e pode ajudar a fomentar a criatividade.

A produção de mapas conceituais foi realizada inicialmente com o uso de papel e lápis, porém, posteriormente, os alunos foram apresentados ao software Cmap Tools e passaram a construir os mapas conceituais seguintes utilizando essa linguagem digital.

Dominando a Tecnologia de Informação e Comunicação, os mapas conceituais podem ser construídos de forma mais dinâmica. 0 passo seguinte foi aprofundar o nível de hierarquização e relação entre os conceitos. Como exemplo dessa segunda fase da prática, trazemos um mapa conceitual produzido para abordar o conteúdo Calor e temperatura no $2^{\circ}$. ano do ensino médio. Na figura 3 , temos um exemplo de um mapa construído usando o CmapTools abordando esse tema.

Notemos que esse mapa pode ser utilizado como um resumo esquemático do que foi aprendido. Como a aprendizagem significativa ocorre mais facilmente quando os novos conceitos ou significados conceituais são englobados sob outros conceitos mais amplos, mais inclusivos, os mapas conceituais devem ser hierárquicos, ou seja, os conceitos mais gerais e mais inclusivos devem se destacar no topo do mapa conceitual. No caso em tela, calor e temperatura destacam-se logo acima. Depois, os termos relacionados vão ficando cada vez mais específicos, explicitando a hierarquia dos termos. 
Figura 3 - Mapa conceitual do conteúdo Calor e temperatura

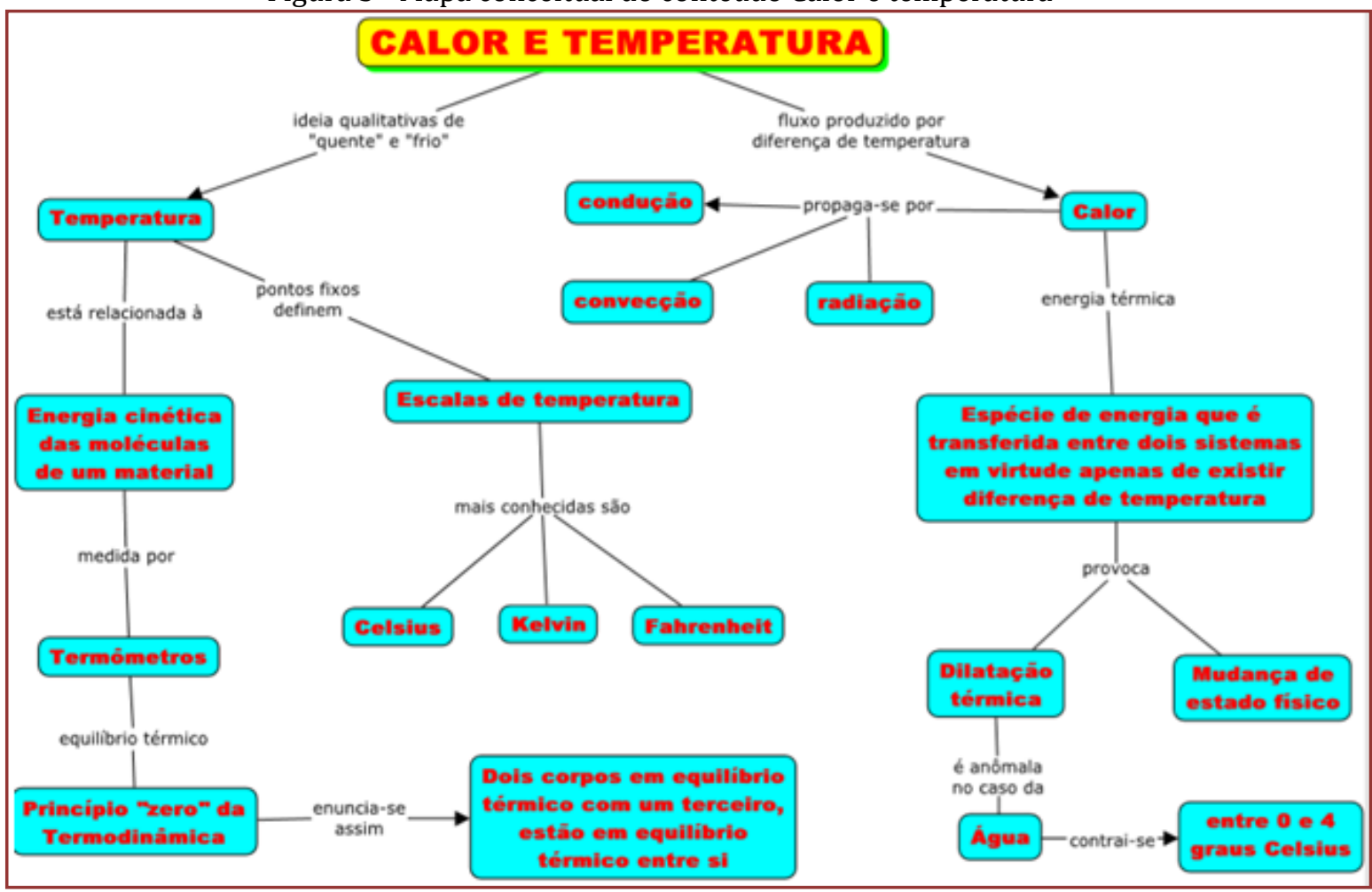

Fonte: elaborado pelos autores

Quando se observa um mapa conceitual, muitas vezes pode-se pensar que não há como fazê-lo diferente, todavia, os significados cognitivos para serem compreendidos dependem de trocas, compartilhamentos e diálogos. Mesmo que assim pensemos, os alunos mostram que o parece ser um desafio é possível. Diversos mapas conceituais são apresentados usando a mesma hierarquia ou, até mesmo, hierarquias diferentes e comprovam as diversas trajetórias que levam a uma aprendizagem significativa do mesmo conteúdo.

Outra vantagem do mapa conceitual é que nossa memória tem uma grande capacidade para recordar imagens visuais específicas. Conforme, Novak e Gowin (1996, p. 44),

reconhecemos facilmente um amigo íntimo numa reunião de centenas de pessoas ou numa fotografia de grupo. Seria extraordinariamente difícil programar um computador sofisticado para fazer reconhecimentos com uma facilidade similar. Na elaboração de mapas conceptuais potencializa-se esta capacidade humana de reconhecer padrões nas imagens com o objectivo de facilitar a aprendizagem e a memória. [...]; Seria, com certeza, desastroso que os professores esperassem que os estudantes memorizassem os mapas conceptuais e fossem capazes de reproduzir o seu conteúdo, a estrutura e os detalhes tal como foram apresentados na aula. Isto apelaria para a máxima capacidade de memória rotineira, que é exactamente o oposto do tipo de actividade de aprendizagem que procuramos fomentar.

Porém, não podemos incorrer no erro de afirmar que qualquer mapa conceitual que venha a ser feito seja bom. Alguns, eventualmente, merecem correções. Outros podem demonstrar conhecimentos prévios errôneos, o que pode nortear o processo de ensino-aprendizagem. Dessa forma, eles servem para indicar o que os discentes já sabem e o que precisa ser reforçado ou esclarecido.

Podemos perceber que, na literatura científica, vários trabalhos abordam a utilização de mapas conceituais em processos de avaliação de aprendizagem. Podemos citar, por exemplo, Cicuto, Mendes e Correia (2013), que investigaram uma proposta de nova forma de utilizar os mapas conceituais com o intuito de verificar como os alunos articulam os diferentes materiais instrucionais indicados para estudo pelo professor. Nesse estudo, eles tiveram a ideia de utilizar os mapas conceituais como ferramentas de avaliação da aprendizagem dos alunos, destacando sua vantagem em relação a outras possibilidades de organizadores gráficos, como os mapas mentais, por exemplo. Os resultados do trabalho deles revelou que houve a 
possibilidade de, através desse processo, do professor poder ler e corrigir os erros conceituais expressos nas proposições elaboradas pelos alunos. Assim, perceberam que, com o uso de mapas conceituais no processo avaliativo, foi possível ao professor também avaliar o seu plano de ensino, com uma percepção de como os alunos articularam os diversos materiais instrucionais indicados pelo docente.

Outro estudo realizado nesse mesmo mister foi apresentado por Krummenauer (2012), o qual utilizou a construção de mapas conceituais como instrumentos de avaliação na disciplina de Física Aplicada I para alunos do curso de Engenharia de Produção. Seu trabalho foi desenvolvido a partir das dificuldades percebidas no uso de operações matemáticas referentes a conteúdos do Ensino Médio e no entendimento de alguns conceitos físicos apresentados por seus alunos. Ele percebeu ao longo do desenvolvimento de sua proposta certa dificuldade inicial dos alunos na construção dos mapas, dificuldade esta que, segundo afirma, foi sendo superada ao longo do projeto. Ele afirma que as versões finais dos mapas conceituais construídos demonstraram um crescimento em nível conceitual, além do estabelecimento correto das relações e hierarquias entres estes conceitos.

Com a prática verificamos que a complexidade dos mapas conceituais se acentua e eles ficam cada vez mais reflexivos. Na figura 4, apresentamos um exemplo de mapa conceitual bem complexo, envolvendo o conteúdo Gravitação universal. Devemos notar que ele atende a vários requisitos: pode substituir um plano de aula, servir como conteúdo de revisão do assunto ou como guia para uma avaliação acerca do tema. Podemos citar, por exemplo, Correia, Silva e Romano Junior (2010), além de Gomes, Batista e Fusinato (2019), como referências que utilizam mapas conceituais como ferramentas de avaliação.

Figura 4 - Mapa conceitual do conteúdo Gravitação universal

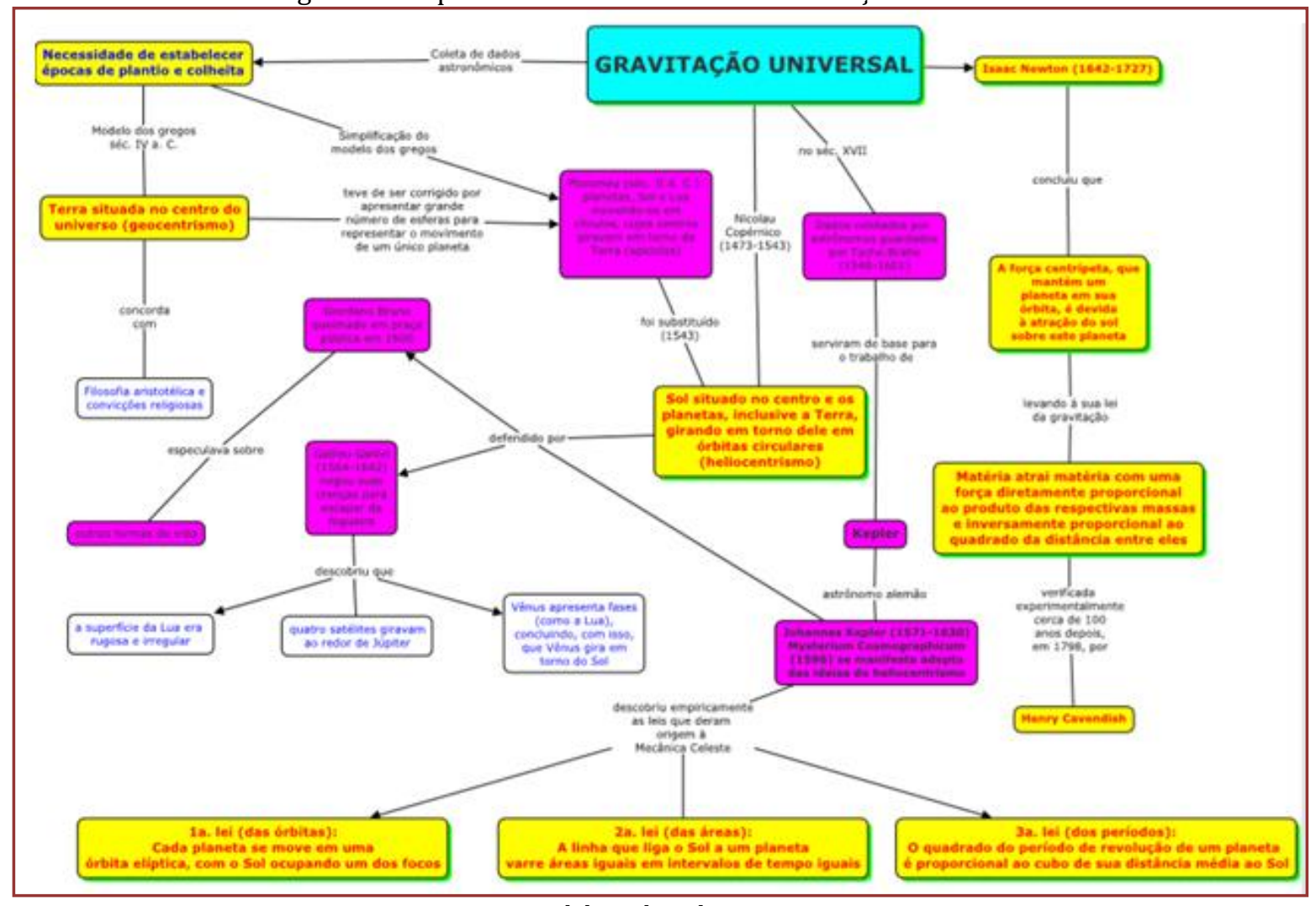

Fonte: elaborado pelos autores

\section{CONSIDERAÇÕES FINAIS}

Consideramos que, numa visão epistemológica construtivista sociointeracionista, o conhecimento é construído com base na linguagem e a mesma se apoia fortemente na dialética. Nesse ponto de vista é importante levantar os conhecimentos prévios dos discentes e, através da epistemologia do professor, fazer o elo deles com a linguagem científica. Diante disto, concluímos que os mapas conceituais, de acordo com a prática que desenvolvemos, cumpre esse papel fundamental no processo ensino-aprendizagem. 0 uso do software Cmap Tools na confecção desses mapas contribui também para o domínio do letramento digital por parte dos discentes. 
Na construção dos mapas conceituais verificamos que os alunos evoluíram bastante na sequência dado, informação, conhecimento e saberes. Com o auxílio de sites de busca, eles adquiriram informações sobre determinados dados e, com a discussão dialogada na apresentação dos mapas, o conhecimento foi aprofundado, evoluindo para a construção dos saberes.

Quando os discentes construíram seus próprios mapas e foi possível compará-los, verificamos que a argumentação e a contra-argumentação permitiu que os alunos construíssem e reconstruíssem o significado dos conceitos. Como a imagem visual tem efeito significativo em nossa memória, pudemos verificar que, com a construção dos mapas conceituais, os discentes, além de compreender melhor o conteúdo, ficaram mais atentos aos conceitos fundamentais, o que comprovou a capacidade desses mapas em atuar como um importante elemento provedor de ensino-aprendizagem.

\section{REFERÊNCIAS}

[1] ALMEIDA, Voltaire de 0.; Moreira, Marco A. Mapas conceituais no auxílio à aprendizagem significativa de conceitos da óptica física. Revista Brasileira de Ensino de Física, v. 30, n. 4, p. 4403.1-4403.7, 2008.

[2] BRADBURY, Ray. Fahrenheit 451. New York: The Random House Plubishing Group, 2003.

[3] CICUTO, Camila Aparecida Tolentino; Mendes, Bárbara Chagas; Correia, Paulo Rogério Miranda. Nova abordagem para verificar como os alunos articulam diferentes materiais instrucionais utilizando mapas conceituais. Revista Brasileira de ensino de Física, v. 35, n. 3, p. 1-8, 2013.

[4] CORREIA, Paulo Rogério Miranda; Silva, Amanda Cristina da; Romano Junior, Jerson Geraldo. Mapas conceituais como ferramenta de avaliação na sala de aula. Revista Brasileira de Ensino de Física, v. 32, n. 4, p. 4402-14402-8, 2010.

[5] FADEL, Charles; Bialik, Maya; Trilling, Bernie. Educação em quatro dimensões: as competências que os estudantes devem ter para atingir o sucesso. Tradução de Bianca Zucchi e Lilian Bacich. São Paulo: Instituto Península e Instituto Ayrton Senna, 2015.

[6] FREIRE, Paulo. Pedagogia do oprimido. 57a. ed. rev. e atual. Rio de Janeiro: Paz e Terra, 2014.

[7] GIROUX, Henry. A. Pedagogia radical: subsídios. São Paulo: Autores Associados, 1983.

[8] GOMES, Ederson Carlos; Batista, Michel Corci; Fusinato, Polônia Altoé. A utilização de mapas conceituais como instrumento de avaliação no ensino de Física. Revista de Ensino de Ciências e Matemática, v. 10, n. 3, p. 58-78, 2019.

[9] KRUMMENAUER, Wilson Leandro. Mapas conceituais como instrumentos de avaliação em uma disciplina de Física no curso de Engenharia de Produção. Revista Espaço Acadêmico, v. 11, n. 131, p. 138-144, 2012.

[10] MARTINS, Renata Lacerda Caldas; Verdeaux, Maria de Fátima da Silva; SOUSA, Célia Maria Soares Gomes de. A utilização de diagramas conceituais no ensino de física em nível médio: um estudo em conteúdos de ondulatória, acústica e óptica. Revista Brasileira de Ensino de Física, v. 31, n. 3, p. 3401.1-3401.12, 2009.

[11] MORETTO, Vasco Pedro. Planejamento: planejando a educação para o desenvolvimento de competências. 10 a . ed. Petrópolis: Vozes, 2014.

[12] NOGUEIRA, Suelen Marçal; de Souza, Lorrany Terezinha Oliveira. Metodologias ativas; brainstorming e mapa conceitual no ensino da Fisioterapia. Cadernos de Educação, Saúde e Fisioterapia, v. 6, n. 12, 2019.

[13] NOVAK, Joseph D; Gowin, D. Bob. Aprender a aprender. Tradução de Jorge Valadares. Lisboa: Plátano Edições Técnicas, 1996. 


\section{Capítulo 3}

Programa Aprendizagem para o 3ํ Milênio (A3M): Ações criativas/inovadoras na Educação Superior

Teresinha de Jesus Araújo Magalhães Nogueira

Lívia Veleda de Sousa e Melo

Débora Furtado Barrera

Letícia Lopes Leite

Marcello Ferreira

Resumo: As tecnologias digitais possibilitam maior flexibilidade, compartilhamento de informações e espaços para interação de forma rápida. Todas essas facilidades chegam às universidades oportunizando processos de inovação educacional e construção de ambientes de ensino e aprendizagem. Desenvolvem-se itinerários personalizados e dinâmicos, por meio das Tecnologias Digitais de Informação e Comunicação (TDIC) e da aprendizagem ativa e colaborativa. Na concepção de inovação educacional como parte de um processo contextualizado de transformações das experiências educacionais, a Universidade de Brasília (UnB) propôs o Programa Aprendizagem para o $3^{\circ}$ Milênio $(\mathrm{A} 3 \mathrm{M})$, uma ação institucional com o objetivo de identificar, promover e socializar práticas educativas inovadoras. Este estudo busca analisar o Programa A3M quanto à sua atuação e colaboração para o desenvolvimento de práticas inovadoras na UnB. Trata-se de uma pesquisa qualitativa, desenvolvida por meio de análise de vídeos, entrevistas, documentações e informações divulgadas no site do A3M. Os resultados evidenciam que o Programa tem contribuído na promoção e divulgação de práticas inovadoras, por meio do incentivo à realização de projetos educacionais, ações de extensão e construção de um portfólio on-line contendo experiências relacionadas a novos desenhos pedagógicos, utilização de tecnologias nas aulas e produção de recursos digitais, por meio de um ensino híbrido. 0 programa contribui ainda para o desenvolvimento de ações formativas, possibilitando o fortalecimento de uma comunidade de compartilhamento de conhecimentos e práticas construídas no cotidiano da aula.

Palavras-chave: Inovação educacional. Criatividade. Híbrido. Educação Superior. 


\section{INTRODUÇÃO}

No cenário do terceiro milênio emergem novos perfis profissionais e novos formatos de ensino e aprendizagem. A educação superior, como palco de desenvolvimento científico e formação profissional qualificada, apresenta-se no foco de discussões. No setor educacional, o desafio é ensinar e aprender nestes novos contextos, com tempos e espaços conectados pelas tecnologias. Uma das questões principais é: como enfrentar os desafios contemporâneos contemplando as necessidades educativas próprias da cultura digital? 0 Programa Aprendizagem para o $3^{\circ}$ Milênio (A3M) tem este foco: desenvolvimento de ações voltadas ao repensar das práticas educativas, promoção de criatividade e inovação na educação, mais especificamente, experiências criativas e inovadoras protagonizadas por professores em aulas presenciais na UnB.

Nas atuais circunstâncias das instituições de ensino neste início do século XXI, confirma-se o pensamento de autores como Prensky (2018) sobre a mudança civilizatória na educação. Nesse sentido, são necessárias decisões e atitudes que possibilitem romper com a dicotomia teoria e prática, historicamente existente no processo de educação formal. A educação acompanha os contextos e as necessidades históricas que se impõem diante das circunstâncias de cada momento de enfrentamento das situações impostas à humanidade.

Da mesma forma, Levy $(1999,2010)$ aponta que as instituições educativas precisam aproveitar as transformações e as possibilidades que surgem na conjuntura da cultura digital para inovar os processos educativos apoiados nas Tecnologias Digitais de Informação e Comunicação (TDIC). David Cavallo e outros autores (2016, p. 3) alertam que "o uso de abordagens ativas para o estímulo à inovação e à criatividade transcende a proposição teórica do conceito TIC, como Tecnologias da Informação e Comunicação". Os autores destacam que o termo TIC enfatiza o uso dessas tecnologias com fim em si mesmo, ou seja, como veículo de transmissão de informação e comunicação. Na visão dos autores, essas tecnologias devem ser vistas "como Tecnologia da Inovação e Criatividade ou Tecnologias da Informação, Comunicação e Computação (TICC)" (CARVALHO et al., 2016, p. 3).

Almeida e Prado (2006, p. 18) destacaram aspectos relacionados à finalidade em relação ao uso da TIC, alertando que "[...] para evitar ou superar o uso ingênuo dessas tecnologias, é fundamental conhecer as novas formas de aprender e de ensinar, bem como de produzir, comunicar e representar conhecimento, possibilitadas por esses recursos [...]". Independente de como denominamos a Tecnologia, é a finalidade em relação ao seu uso que deve ser apropriada nesse momento de inovação educacional, o qual requer criatividade, criticidade e o conhecimento das novas linguagens e dos recursos tecnológicos de comunicação, informação e inovação. 0 uso consciente, planejado de recursos tecnológicos pode contribuir para o desenvolvimento de metodologias ativas e de habilidades e competências para atuar na sociedade em rede (MOAN, 2018).

Seguindo a mesma lógica de raciocínio, Moran (2000, p. 137-138) defende que a tecnologia, por si só, não é a resposta aos problemas e aos desafios da educação, os maiores desafios são o de ensinar e aprender “[...] avançamos mais se soubermos adaptar os programas previstos às necessidades dos alunos, criando conexões com o cotidiano, com o inesperado [...]". As instituições de educação superior estão se reinventando, se reprogramando para atender as situações sociais jamais previstas.

O Programa Aprendizagem para o $3^{\circ}$ Milênio (A3M) foi pensado nessa perspectiva. O A3M valoriza experiências educacionais inovadoras, por meio da utilização de novos desenhos e estratégicas pedagógicas com foco na aprendizagem significativa, engajamento e motivação. Este estudo apresenta uma análise do Programa A3M, quanto à sua atuação e colaboração para o desenvolvimento de práticas inovadoras na UnB, bem como a institucionalização e socialização desses resultados, considerando, também, a formação contínua de alunos e professores.

A pesquisa é qualitativa, fundamentada em Minayo (2001), Ghedin e Franco (2008), Thiollent (2011), desenvolvida por meio de documentação direta e indireta, conforme classificação de Lakatos e Marconi (2002). Para coleta de dados sobre o objeto estudado utilizaram-se técnicas de observação, entrevistas semiestruturadas, fontes do tipo vídeos, sites, entre outras. Foi realizada análise de conteúdo das diversas informações coletadas, de acordo com Bardin (2011).

Para melhor compreensão deste estudo estruturou-se as seções que seguem, no intuito de discutir questões sobre o ensino e a aprendizagem no contexto da inovação educacional e das possibilidades de aprendizagem neste novo milênio, buscando-se os significados e os sentidos que emergem dessa temática, bem como apresentar resultados sobre a contribuição do Programa A3M nos processos de ensino, de aprendizagem e de formação contínua na UnB. 


\section{CRIATIVIDADE/INOVAÇÃO E TECNOLOGIA: CONSTRUINDO NOVOS PROCESSOS DE ENSINO E APRENDIZAGEM}

Ao se discutir sobre inovação educacional é consenso de pesquisadores que esta envolve mudanças paradigmáticas na forma de ensinar e aprender. Requer o desenvolvimento do pensamento complexo, aberto às transformações. Conforme Behrens (1999, p. 383), poucos professores refletem sobre a sua ação docente e, ao ter a oportunidade de promover essa reflexão, se desperta o "professor que anseia por modificar sua prática pedagógica, mas não sabe como alterá-la".

O Programa A3M traz esse enfoque, oportunizar as trocas de experiências entre os professores, ampliando as condições para aqueles que querem modificar suas práticas, mas não sabem por onde começar. A meta do Programa é desenvolver um Portfólio de experiências criativas e inovadoras experimentadas na UnB, na promoção de um ensino e aprendizagem autônomo, interativo e baseado na troca de experiências entre os pares. O Programa busca também a formação contínua, promoção de práticas inovadoras, criação de objetos de aprendizagem e conteúdo a partir das TDIC.

Destaca-se, neste estudo, a inovação na concepção de Maldonato e Dell'Orco (2010, p. 6) como:

[...] capacidade de a mente inferir significados inusitados a partir de informações aparentemente banais; produzir respostas divergentes e criativas; olhar a realidade convencional com uma óptica insólita; gerar, em suma, hipóteses, cenários e soluções diferentes de maneira quase casual, mesmo fora de uma lógica estruturada.

São vários os significados sobre a inovação, observando-se algumas dimensões e contextos em que está inserida. No contexto educativo, Cavallo $(2016$, p. 3) afirma que "[...] entende-se por inovação educacional as intervenções que ocorrem em nível local, por iniciativa de estudantes, educadores, escolas ou comunidades, e que possibilitam a produção de novos significados, respostas e hipóteses em relação aos desafios do presente". Salienta-se o fato de a inovação possibilitar "novos significados".

A inovação educacional delineia-se como um processo de transformações das práticas educativas, não como uma simples mudança no formato da aula, ou pelo uso da tecnologia com um fim em si mesmo. Mas, como um processo contextualizado à realidade do estudante, em que se busca como finalidade principal a aprendizagem ativa, por meio da mediação realizada pelo professor. (MORAN, 2018).

Nesse caminho do ensino e aprendizagem, inter-relacionados às tecnologias e à utilização de recursos desenvolvidos com finalidades específicas para o desenvolvimento da prática pedagógica inovadora, reconhece-se que esse processo requer criatividade, rupturas e continuidades em relação às práticas que ainda estão presentes. Libedinsky (2014, p. 3, tradução nossa), lança o seguinte questionamento: "que tipo de inovações podemos pensar? Inovar em educação implica em muitas e variadas coisas? ". Considera-se que inovar não significa apenas utilizar tecnologias móveis, como a internet e os seus aplicativos, mas, refletir e compreender as finalidades e as possíveis formas de aprendizagem que essas tecnologias podem proporcionar, como as novas ecologias da aprendizagem discutidas por Coll (2009).

Para Fullan (2007), a inovação pedagógica pressupõe a utilização de materiais didáticos que se integrem aos recursos tecnológicos diversificados, a busca de planejamentos e estratégias que facilitem e redirecionem os processos de ensino, aprendizagem e avaliação. Esses processos aparecem de forma integrada. A inovação não se apresenta em uma simples mudança na forma de ensinar, mas exige modificações no modo de pensar, planejar e executar a prática pedagógica, tendo em vista redimensionála.

Outro fator relevante é que a inovação requer criatividade. Apresenta-se a noção de criatividade definida por Cavallo (2016, p. 3) "como sendo o conjunto de habilidades cognitivas que são usadas para resolver problemas ou gerar soluções alternativas. Ou seja, são habilidades mentais que se desenvolvem ao longo da vida". Considera-se que criatividade e inovação estão intrinsecamente relacionadas, destacam-se frases do escritor Ferreira (2012, p. 1), que demonstra essa inter-relação: "a inovação é a criatividade aplicada em algum serviço ou produto. A criatividade é um processo individual, já a inovação é um processo coletivo". Há também uma íntima relação entre inovação/criatividade e o uso de tecnologia.

A partir da Tecnologia Digital de Informação e Comunicação (TDIC), os processos de ensino e de aprendizagem podem ser estimulados e ampliados pela facilidade de conexão, de possibilidades de interações síncronas e assíncronas, por meio de recursos e de ferramentas encontrados em ambientes de aprendizagem digital. Várias são as formas de se usar a tecnologia, como a internet. Em particular, a conectividade mobile facilita o acesso às atividades promovidas pelo processo de ensino e de 
aprendizagem. A capacidade de dispositivos e de grupos se conectarem (interconectividade) possibilita novos formatos de aprendizagens, instituem-se novos cenários de ensino em que "[...] a aprendizagem está e estará cada vez mais, modelada pelas TIC e mais concretamente pelas tecnologias digitais da informação e comunicação" (COLL, 2013, p. 4).

Sharples (2015) afirma que o professor em sala de aula pode dar continuidade à aprendizagem para além dos espaços escolares. Ao buscar a interconectividade o professor possibilita maior integração entre a aula presencial e a aula em ambientes virtuais. Nesse sentido, a tecnologia possibilitou que a universidade estabeleça um diálogo com o mundo, interconectar-se para que o mundo entre na comunidade acadêmica (BACICH; MORAN, 2015). Com a conectividade é possível se desenvolver novas formas de ensinar, em que o professor busca o uso de metodologias ativas por meio da mediação pedagógica, possibilitando um ensino flexível e híbrido. Segundo Moran (2018, p. 2) "Metodologias ativas são estratégias de ensino centradas na participação efetiva dos estudantes na construção do processo de aprendizagem, de forma flexível, interligada, híbrida".

Ao se abordar o tema metodologia ativa, concorda-se com Moran (2013, p. 1), ao afirmar que essas práticas estão "[...] muito em voga na educação básica e superior, como abordagens pedagógicas que privilegiam a aprendizagem dos estudantes por descoberta, por investigação ou resolução de problemas". O autor afirma ainda que, embora não seja um tema novo (já estudado por Dewey no fim do século XIX), tem-se hoje mais evidências científicas da sua importância para a aprendizagem mais ampla e profunda (Psicologia, Neurociência, Pedagogia) e da urgência na sua implementação num mundo em profunda transformação.

Nessa mesma concepção, observam-se diferentes interpretações a respeito do alcance e do significado desse termo. As metodologias, segundo Moran (2013, p. 1) podem ser entendidas como: i) domínio de algumas técnicas e abordagens para envolver mais os alunos (aula invertida, rotação por estações, projetos), utilizadas predominantemente de forma individual; ii) estratégias mais complexas centradas na participação dos estudantes e na integração entre áreas de conhecimento e docentes (salas de aula adaptadas, projetos integradores); iii) um movimento de transformação mais ampla de instituições de educação básica e superior, por meio da reestruturação do currículo, dos espaços, da avaliação e da maior participação da comunidade, envolvendo gestores, docentes, funcionários, estudantes, famílias.

Remetendo à discussão inicial, o uso de metodologias ativas requer mudanças paradigmáticas. E como afirma Moran (2013, p. 1):

Não é simples mudar paradigmas mentais consolidados, sair da posição central de docentes para a de mediadores. Exige um investimento maior em formação, experimentação, mais tempo de preparação das atividades, de planejamento em conjunto com vários colegas, de participação maior dos alunos e ter um domínio mais amplo das tecnologias digitais.

O processo é complexo. Alguns professores desenvolvem experiências inovadoras com uso de TDIC de forma mais rápida; outros precisam de mais tempo. Observam-se exemplos exitosos, mas há um grupo que resiste às mudanças, continuam apegados ao paradigma conservador, às práticas tradicionais. Vale a pena destacar que, para ampliar a utilização de práticas inovadoras na universidade, ou em outra instituição educativa, é decisivo o papel dos gestores, tanto na promoção de incentivo ao uso de novos desenhos pedagógicos (organização de projetos, eventos, espaços de troca, além de infraestrutura física e de pessoal para apoiar as práticas) quanto na revisão dos normativos institucionais visando à facilitação dessas práticas.

0 terceiro milênio requer processos de ensino e aprendizagem que agreguem a mobilidade e a conectividade. 0 ensino contemporâneo, inovador, busca um conjunto de atividades que conectem espaços físicos ao virtual, possibilitando a aprendizagem ativa (BARRON, 2004). Para Coll (2013, p. 40) existe um complexo cenário educativo "[...] que proporcionam as redes sociais, os mundos e entornos virtuais, as comunidades virtuais de interesse, prática de aprendizagem e os jogos on-line em geral, criados pelas TIC digitais".

As novas ecologias de aprendizagem disponibilizam oportunidades de interação entre pessoas, recursos e ferramentas de comunicação e construção de conhecimento, possibilitando ensino e aprendizagem colaborativos, atribuição de novos significados e obtenção de novas metodologias. Elas representam a personalização de ações enquanto um ato de aprendizagem. Para Coll (2013, p. 33), "[...] a personalização da aprendizagem é uma necessidade crescente, já é uma realidade imposta às escolas e aos sistemas, é uma tendência que se anuncia". Essas mudanças decorrem das atuais configurações sociais que produzem 
significativas transformações na forma de ensinar e de aprender, tendo como contexto a sociedade da cultura digital. Requer também, o repensar das estruturas organizacionais das instituições educativas, os sistemas de ensino, as metodologias, o currículo e a formação do professor.

Nesse cenário, considera-se incorporar momentos on-line à educação presencial, por meio do ensino híbrido, possibilitado pelas tecnologias digitais, com mais flexibilidade, compartilhamento, comunicação. Para Horns e Staker (2015, p. 34), o ensino híbrido é considerado como um programa educacional formal no qual o educando aprende, em parte, por meio do ensino on-line (uso de ferramentas pela internet), mas "com algum elemento de controle dos estudantes sobre o tempo, o lugar, o caminho e/ou ritmo." Autores como Bachic, Tanzi Neto e Trevisani (2015, p. 29) afirmam que o ensino híbrido

não se reduz a metodologias ativas, o mix de presencial e on-line, de sala de aula e outros espaços, mas que mostra que, por um lado, ensinar e aprender nunca foi tão fascinante, pelas inúmeras oportunidades oferecidas, e, por outro, tão frustrante, pelas inúmeras dificuldades em conseguir que todos desenvolvam seu potencial e se mobilizem de verdade para evoluir sempre mais.

Para Moran (2018, p. 1), o híbrido é uma das dimensões presentes na educação formal. 0 autor diferencia diferentes práticas:

1) o modelo blended, semipresencial, misturado, em que nos reunimos de várias formas - física e digital - em grupos e momentos diferentes, de acordo com a necessidade, com muita flexibilidade, sem os horários rígidos e planejamento engessado;

2) Metodologias ativas: aprendemos melhor através de práticas, atividades, jogos, projetos relevantes do que da forma convencional, combinando colaboração (aprender juntos) e personalização (incentivar e gerenciar os percursos individuais)

3) 0 modelo on-line, com uma mistura de colaboração e personalização, em tempo real e através de multiplataformas digitais móveis. Cada aluno desenvolve um percurso mais individual e participa em determinados momentos de atividades de grupo.

Nesse conjunto de possibilidades apresentadas por Moran (2018, p.1), destaca-se a combinação de metodologias ativas, ensino híbrido e tecnologias móveis no delineamento de formatos criativos de ensinar e aprender. Por meio da aprendizagem ativa a ênfase está no papel protagonista do aluno, no seu envolvimento direto, participativo e reflexivo nas etapas do processo. Associada ao ensino híbrido destaca-se "[...] a flexibilidade, a mistura e compartilhamento de espaços, tempos, atividades, materiais, técnicas e tecnologias que compõem esse processo ativo".

O contexto apresentado possibilita que sejam discutidas, na seção seguinte, as ações do Programa A3M, considerado neste estudo como uma proposta institucional para alavancar processos de criatividade e inovação educacional na UnB. Considera-se que o Programa tem possibilitado identificar, promover e socializar experiências inovadoras com uso de metodologias ativas e ensino híbrido, bem como a formação profissional contínua, na concepção de autores como Nóvoa (2002), entre outros.

\section{CONTRIBUIÇÕES DO PROGRAMA A3M: AÇõES CRIATIVAS/INOVADORAS DE ENSINO/APRENDIZAGEM E FORMAÇÃO NA UNB}

O Programa Aprendizagem para o 3ํㅗㄹ Milênio (A3M) teve sua origem em 2017, como um programa institucional da Universidade de Brasília. No desenvolvimento de suas estratégias de ação, partiu da hipótese da existência de experiências inovadoras desenvolvidas pelos professores em aula presencial, mas que, por serem trabalhadas de forma isoladas, precisavam ser conhecidas, valorizadas e apoiadas institucionalmente. 0 objetivo seria fortalecer o uso e experimentações de novos desenhos pedagógicos pelos demais professores, visando à promoção do ensino e aprendizagem ativos, alinhados com o perfil dos protagonistas da educação para um novo milênio. 
Nos primeiros anos de desenvolvimento, o programa atuou no intuito de valorizar experiências educacionais de professores da universidade e construir, a partir dessas práticas, um portfólio de recursos metodológicos para os cursos da universidade e da comunidade em geral. Outra ação relevante derivada do Programa A3M é a formação contínua de professores, por meio do projeto Rotas de Inovação Universitária - RIU.

0 projeto Rotas de Inovação Universitária (RIU) faz parte do Programa Aprendizagem para o 3ํㅡㄹ Milênio (A3M) e atua especificamente no propósito de estimular a formação docente e de outros membros da comunidade acadêmica para o desenvolvimento de diferentes desenhos pedagógicos, considerando o uso de tecnologias educacionais, mediação pedagógica e a integração de espaços presenciais e a distância. (PROJETO ROTAS DE INOVAÇÃO UIVERSITÁRIA - RIU, 2019, p. 1).

No seu conjunto de ações, o A3M tem possibilitado promover estratégias articuladas a processos de inovação e criatividade no âmbito institucional, com foco no ensino e aprendizagem, na pesquisa e extensão. Entre estas estratégias, destaca-se a formação docente propiciada a partir da interação entre os membros da comunidade acadêmica que estão promovendo experimentando novas práticas. Essas ações são essenciais para possibilitar novos formatos de aula na UnB e ampliar o uso de recursos tecnológicos no processo de ensino aprendizagem em âmbito local e na comunidade em geral.

O programa A3M nasce com os objetivos de identificar, promover e divulgar práticas educativas criativas e inovadoras na instituição. Com base nesses objetivos, a seguir, apresenta-se o resultado do estudo, desenvolvido em categorias, sendo estas: (A) Identificação de experiências inovadoras na UnB, cujas subcategorias são: 1) Identificação dos projetos por áreas de conhecimento; 2) Identificação dos projetos por áreas da CNPq; (B) Ações de divulgação e promoção das experiências inovadoras; C) Ações de formação.

\subsection{CATEGORIA A - PROGRAMA A3M: CONTRIBUIÇÃO NO PROCESSO DE IDENTIFICAÇÃO DE EXPERIÊNCIAS CRIATIVAS E INOVADORAS EM AULAS DA UB}

No início do A3M, foram discutidas quais estratégias utilizar para identificar ações com foco em novos desenhos pedagógicos. Considerando o tamanho da Universidade e sua complexidade, optou-se pela promoção de editais de fomento. Até o momento, houve três editais com o intuito de apoiar projetos para o desenvolvimento de metodologias educacionais inovadoras, preferencialmente com o apoio de Tecnologias de Informação e Comunicação (TIC), visando contribuir para a melhoria do processo de ensino e aprendizagem na UnB.

O Edital CEAD/DEG/DPI n 01/2019 teve como objetivos (geral e específico):

selecionar propostas para o apoio financeiro a projetos que busquem ações visando a: a) incentivar práticas acadêmicas inovadoras; b) incentivar a pesquisa e a produção de novos conhecimentos que proporcionem a incorporação de metodologias educacionais inovadoras no processo de ensino e de aprendizagem; c) desenvolver metodologias inovadoras para o ensino e a aprendizagem, que resultem em processos e em produtos nos cursos da UnB; d) incentivar a cultura acadêmica para o uso das TICs como instrumento útil para o desenvolvimento do ensino e da aprendizagem; e) favorecer a institucionalização de métodos e de práticas inovadoras de ensino e de aprendizagem na UnB. (UNIVERSIDADE DE BRASÍLIA, 2019).

As temáticas dos projetos deveriam considerar o desenvolvimento de metodologias ou de recursos educacionais capazes de promover estratégias de acolhimento e de engajamento dos estudantes da universidade. No quadro a seguir, é possível visualizar o quantitativo de propostas submetidas, aprovadas e em desenvolvimento, identificadas nas três seleções promovidas pelos editais.

Categoria A - Experiências inovadoras na modalidade presencial na UnB 
Quadro 1 - identificação de experiências inovadoras Editais de 2017 - 2019

\begin{tabular}{|c|c|c|c|}
\hline Editais e ano & $\begin{array}{l}\text { Propostas } \\
\text { submetidas }\end{array}$ & $\begin{array}{l}\text { Propostas } \\
\text { aprovadas }\end{array}$ & $\begin{array}{c}\text { Propostas em } \\
\text { desenvolvimento }\end{array}$ \\
\hline 1을 Edital 2017 & 91 & 80 & 22 \\
\hline 2º Edital 2018 & 50 & 47 & 34 \\
\hline 3을 Edital 2019 & 43 & $42^{1}$ & 0 \\
\hline
\end{tabular}

Fonte: Elaborado com base em documentação do A3M/CEAD de 2017 e 2019.

Ao todo, foram 184 projetos identificados, e 169 aprovados pela comissão de avaliação. É relevante compreender que cada projeto foi avaliado por três professores da UnB com experiência em inovação educacional. Destas, 52 foram executados e 4 estão em andamento.

É relevante informar que o primeiro edital contou com 91 propostas submetidas, sendo 80 classificadas e 12 receberam fomento direto (para compra de materiais, entre outros). Os demais 10 projetos - que foram classificados sem fomento direto - aceitaram ser executados com apoio do programa. 0 segundo edital teve 50 propostas inscritas, 47 classificadas e 34 em execução (com fomento direto - bolsas para os estudantes), das quais 12 foram sem fomento direto. 0 último edital (2019) teve 43 propostas inscritas e 42 classificadas.

Os projetos compreendem as três grandes áreas de conhecimento e as nove áreas definidas pelo Conselho Nacional de Desenvolvimento Científico e Tecnológico (CNPq), conforme Gráficos 1 e 2.

Subcategoria: 1 - Gráfico 1 - Distribuição dos projetos nas três áreas de conhecimento

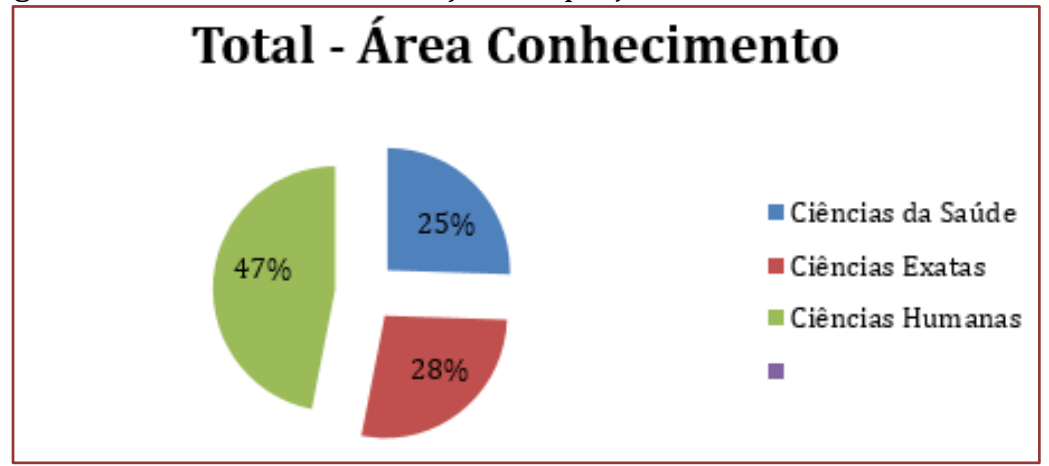

Ao se observar as áreas de Saúde, Exatas e Humanas, esta última tem um percentual maior no quantitativo de projetos.

Subcategoria 2 - Gráfico 2 - Identificação dos projetos por áreas da CNPq.

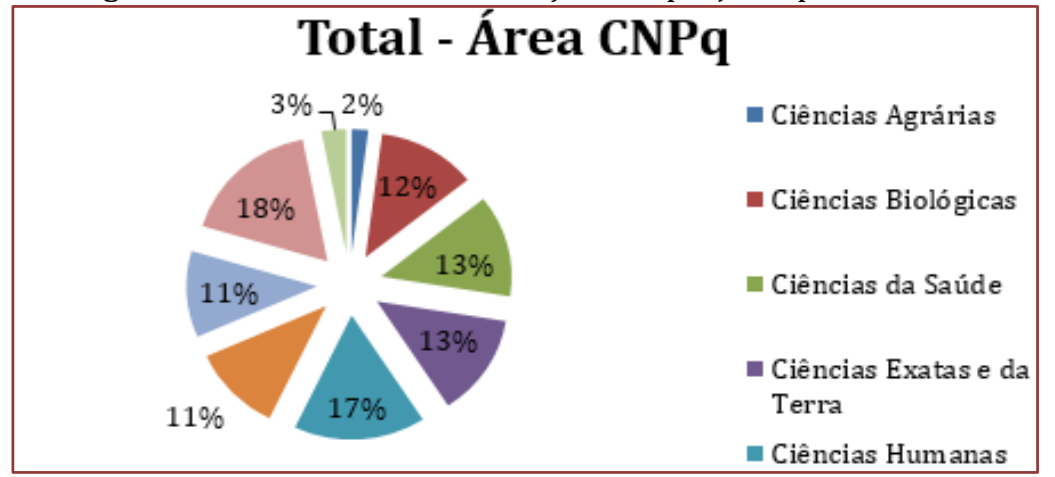

Fonte: Elaborado com base em relatórios e documentos do A3M (2017/2018/2019), 2020.

\footnotetext{
1 As propostas selecionadas em 2019 não iniciaram a execução devido à "suspensão do calendário acadêmico do primeiro semestre de 2020 pelo tempo que durar a situação de emergência de saúde relacionada à pandemia do novo Covid-19 no Distrito Federal" (AS AUTORAS A PARTIR DE RELATÓRIOS).
} 
No Gráfico 2, fica evidente o alcance dos projetos em todas as nove áreas do CNPq, revelando a reflexão sobre as práticas pedagógicas de uma forma geral na Universidade e, ainda, que os professores estão reagindo ao desafio imposto pela cultura digital, de se renovar e de inovar os processos de ensino de aprendizagem.

Para as próximas análises, foram considerados apenas os projetos disponíveis no site do A3M, os quais abrangem cinco áreas do conhecimento, predominando a área de Ciências Exatas e da Terra. Nos editais do A3M, estava previsto a divulgação dos recursos educacionais e propostas de metodologias desenvolvidos para toda a comunidade acadêmica, de modo que pudessem ser reutilizados nas diversas áreas e cursos da UnB ou em outras instituições de educação. Esses projetos tiveram também como critério contemplar a melhoria do aprendizado, os níveis de satisfação e o envolvimento dos discentes.

\subsection{CATEGORIA B - AÇõES DE DIVULGAÇÃO E PROMOÇÃO DAS EXPERIÊNCIAS INOVADORAS: FORTALECENDO 0 TRIPÉ ENSINO-APRENDIZAGEM, PESQUISA E EXTENSÃO}

O Programa A3M em sua finalidade de promoção e divulgação da inovação educacional na UnB desenvolveu diversas ações durante esses três anos de existências (2017-2019), no intuito de acompanhar, discutir e divulgar as novas possibilidades de desenvolver a criatividade e a inovação na educação, oportunizadas pelas novas configurações interpessoais, sociais, econômicas, políticas e tecnológicas, advindas da cultura digital (BOLL, 2013). Esses processos de ensino e aprendizagem no novo milênio exigem o redesenhar de metodologias e recursos didáticos pedagógicos, com as marcantes características de serem mais flexíveis, híbridos e inter-relacionados à realidade. Conectam-se espaços e tempos, entre o ensino presencial e virtual, a partir das TDIC, que em seu conjunto, integradas à criatividade e à inovação ampliaram e modificaram a interação entre os agentes educativos, bem como as possibilidades de aprendizagem autônoma por meio da mediação pedagógica.

Portanto, o Projeto A3M busca em harmonia com o Plano de Desenvolvimento Institucional (PDI) da UnB (2018-2022), compreender e atender as demandas do novo milênio; e, entre outros direcionamentos, intenta ainda fortalecer o desenvolvimento e o aprimoramento das práticas de ensino e aprendizagem na Universidade.

O PDI (2018-2022) prioriza, em relação aos aspectos didático-pedagógicos, a valorização da docência na graduação, garantida por meio do apoio à formação de docentes; a criação de políticas de incentivo à inovação e à produção científica e as inovações tecnológicas e metodológicas como suportes estratégicos à aprendizagem discente e à produção científica.

Reconhecendo nas experiências apoiadas pelo Programa a inovação educacional, na perspectiva de autores como Cavallo (2016, p. 3), um processo constituído por intervenções em nível local (na escola, aula), "por iniciativa de estudantes, educadores, escolas ou comunidades, e que possibilitam a produção de novos significados, respostas e hipóteses em relação aos desafios do presente". Observa-se também, nos projetos, em particular e no contexto geral do A3M, a criatividade "definida como sendo o conjunto de habilidades cognitivas que são usadas para resolver problemas ou gerar soluções alternativas. Ou seja, são habilidades mentais que se desenvolve ao longo da vida".

Nesse sentido, os professores em suas aulas presenciais trazem essas habilidades e junto com os alunos desenvolvem experiências diversas. Um exemplo é o projeto "OEB: Poiese e Dissenso", ambiente virtual e gamificado que funciona de forma colaborativa, desenvolvendo objetos de aprendizagem poéticos. São ações que estimulam o protagonismo do estudante e valorizem a experiência da pesquisa, da reflexão, da produção e do compartilhamento, conforme Site Programa A3M. 


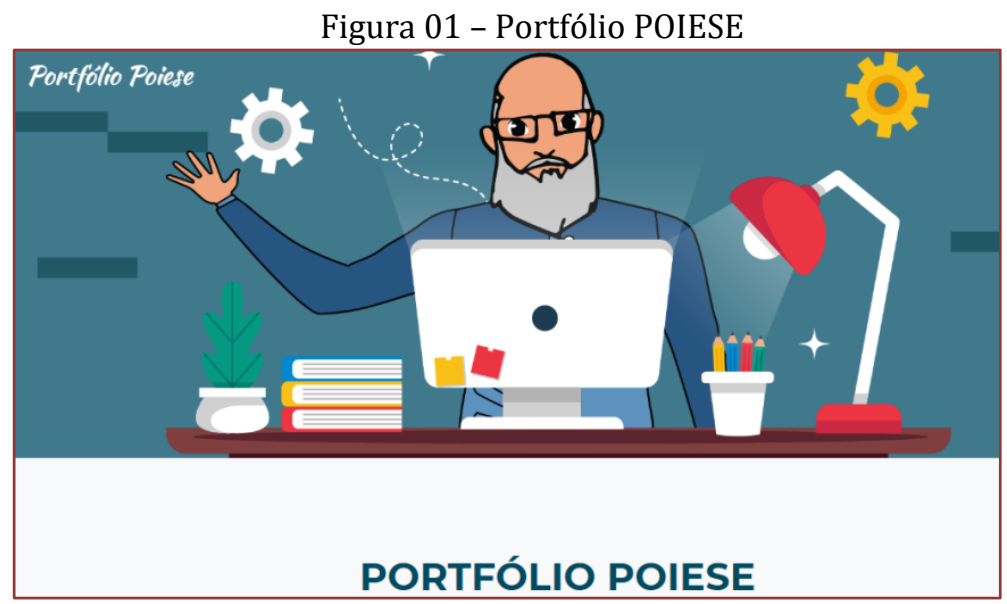

Fonte: site A3M, 2020.

Observa-se que o projeto possibilita o desenvolvimento da metodologia ativa, híbrida e flexível. Os alunos praticam sua criatividade e participam da inovação na forma de trabalhar a disciplina presencial, utilizando ambiente presencial e virtual. Há uma diversificação das estratégias e atividades, como gamificação, história em quadrinhos, júri simulado, produção de vídeos, e escrita autoral. 0 projeto valoriza novos desenhos pedagógicos, o uso de tecnologias e o protagonismo do aluno.

Para divulgar as ações de inovação educacional, foram promovidas diferentes ações de extensão, como: minicursos; oficinas; eventos; palestras com especialistas nas diversas áreas que envolvem a utilização de TDIC e inovação educacional, entre outros temas de interesse acadêmico. Observa-se que, por meio de ações diversas, a pesquisa e a produção científica foram promovidas, bem como foram desenvolvidas atividades de extensão universitária. O Programa A3M possibilita a socialização de práticas inovadoras, incentivando o uso dessas práticas por toda a universidade e, ao mesmo tempo, desmitificando o uso da TDIC e das metodologias ativas.

Figura 02: Programa A3M: promoção de metodologias ativas e recursos didáticos

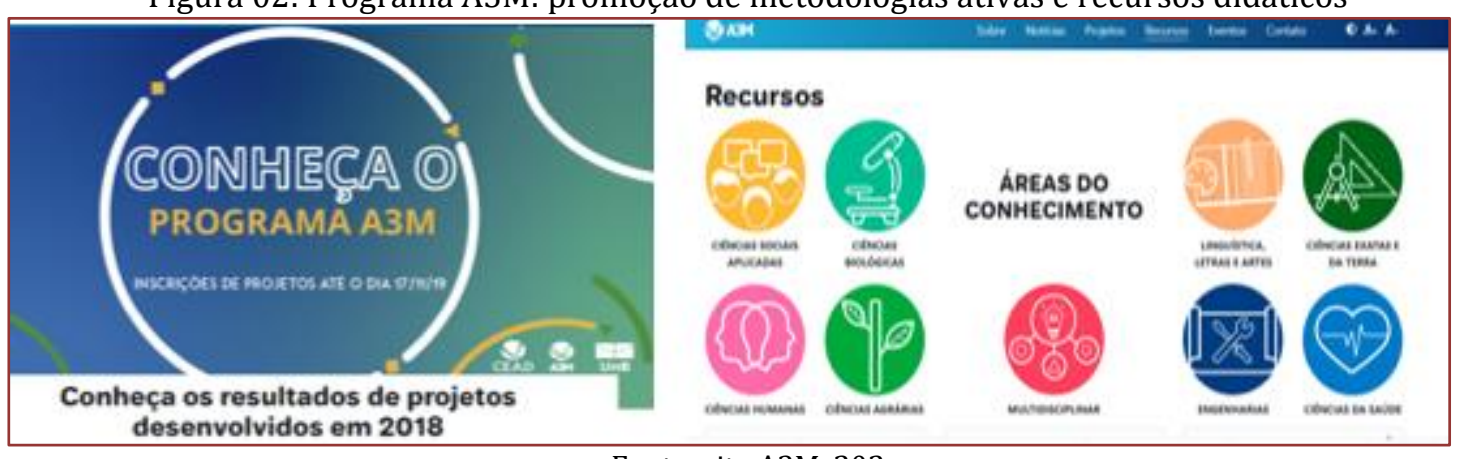

Fonte: site A3M, 202

Além disso, o site A3M possui projetos, vídeos explicativos e, ainda, um passo a passo de como reaplicar as experiências para a obtenção de resultados semelhantes (metodologias ativas e/ou recursos didáticos). Todo esse material está disponível para a comunidade universitária da UnB e para todos que quiserem acessar o site. Com efeito, é uma ação institucional que está disponível para pessoas interessadas na área.

\subsection{CATEGORIA C - PROGRAMA A3M E FORMAÇÃO CONTÍNUA}

Nessa categoria, discute-se a contribuição do Programa A3M quanto à formação contínua. Para Nóvoa (2002, p.56), "o espaço pertinente da formação contínua já não é o professor individual, mas sim o professor em todas as suas dimensões colectivas, profissionais e organizacionais". Nesse sentido, o Programa A3M tem promovido a formação contínua de professores por meio do fortalecimento de uma comunidade de aprendizagem envolvida em projetos e ações de extensões, das quais se derivam desenhos e recursos pedagógicos que são socializados por meio do site e de atividades de extensão e pesquisa, 
como: palestras; seminários; encontros temáticos; workshops; oficinas; reuniões entre os coordenadores dos projetos selecionados pelo programa para troca de experiências. Por meio dessas ações, é possível ainda socializar e divulgar experiências criativas e inovadoras na UnB com pesquisadores de outras instituições, possibilitando intercâmbios de saberes e experiências.

Uma ação importante com o tema da formação continuada é o projeto Rotas de Inovação Universitária (RIU), que integra as ações do A3M com as demandas de formação e inovação pedagógica. "O RIU objetiva propiciar ações e espaços de formação com foco em competências pedagógicas para o desenvolvimento de novos perfis profissionais, capazes de acompanhar a inovação educacional vivenciada nos cenários educativos contemporâneos" (PROJETO ROTAS DE INOVAÇÃO UNIVERSITÁRIA - RIU, 2019, p. 1).

O A3M tem se utilizado dos avanços tecnológicos e científicos, bem como das mudanças nas formas de viver, interagir e aprender na cultura digital, a exemplo das ideias de Boll (2013), Takahashi (2000). As ações do Programa A3M têm contribuído ao longo desses três anos para possibilitar estratégias e possibilidades para os professores atuarem na cultura digital, o que requer inovação educacional. 0 Programa busca promover rupturas com padrões e modelos rígidos de ensino (ainda vigentes) e ampliar as experiências relacionadas ao uso de diferentes desenhos metodológicos e recursos educacionais, desenvolvidos no anonimato das salas de aulas presenciais da UnB.

O Portfólio virtual do Programa A3M é um aliado nesse sentido de revelar/promover as ações criativas e inovadoras, pois propõe a construção dinâmica de um ambiente de ensino e aprendizagem, contendo vídeos, textos, imagens, hiperlinks e espaços de interação. Considera-se a relevância do Programa e sua contribuição para o ensino, a pesquisa e a extensão na promoção de um processo de aprendizagem ativa e colaborativa na comunidade local e global.

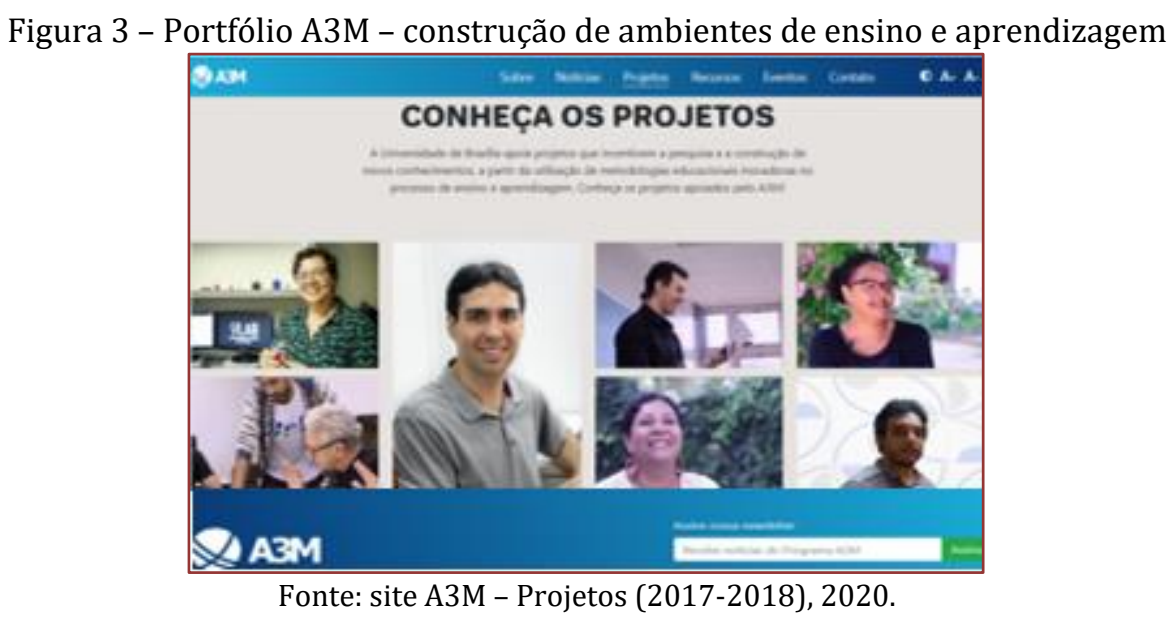

A Figura 3 apresenta o Portfólio virtual que mostra as fotos dos professores-coordenadores dos projetos apoiados/desenvolvidos pelo A3M, com link de acesso aos resultados de experiências desenvolvidas em aula (recursos e metodologias). Os projetos executados pelo Programa A3M possuem a predominância do uso de TDIC, bem como outras formas de tecnologias. É consenso que aulas criativas, dinâmicas, híbridas com uso de metodologias ativas e de recursos tecnológicos podem fazer a diferença no processo de ensino e aprendizagem na educação superior, como estudam diferentes pesquisadores como Barron (2004), Boll (2013), Coll (2013), Moran (2017), Bacich e Moran (2015), entre outros.

\section{CONSIDERAÇõES FINAIS}

A inovação educacional é algo necessário e constante no dia a dia da aula. Ao se observar o contexto da universidade pública no Brasil percebe-se que ainda há muito a se fazer em relação à inovação, ao preparo para o ensino e aprendizagem nesses novos cenários. A inovação para atender ao terceiro milênio exige que, em vários contextos, mais especificamente no educacional, o docente e a equipe gestora se disponham a um trabalho contínuo de investigação dos processos de aprendizagem com o uso de novos recursos, estratégias pedagógicas, diversidades dos meios e análise de comportamentos. Considera-se que a inovação, assim como toda mudança real, envolve mudanças paradigmáticas, o repensar a respeito das 
concepções de mundo e das práticas pedagógicas, visando o seu redirecionamento. Esse movimento requer o reconhecimento da complexidade, de incertezas e de instabilidades mais fortes nesse milênio.

Portanto, é fundamental repensar os processos de ensino e aprendizagem, tornando-os mais dinâmicos, combinando tempos e espaços além do presencial. Considera-se que, na intrínseca relação entre teoria/prática e criatividade é que se desenvolve a inovação, concebida como um processo de ações com as quais se rompem com paradigmas de um ensino mecânico, tecnicista. Com isso, são estimuladas práticas contextualizadas, criativas e críticas, bem como mais planejadas, flexíveis, abertas para serem modificadas, redirecionadas e com finalidades voltadas para aplicação na realidade/contexto em que o educando se insere.

Nesse contexto, o Programa A3M, cuja meta é identificar, promover e valorizar as ações criativas e de inovação voltadas para o efetivo ensino e aprendizagem, contribui na identificação de experiências inovadoras aplicadas por professores, em suas aulas presenciais na UnB, por meio de editais de fomento e apoio didático-pedagógico. Observou-se também a realização de eventos, palestras, minicursos, oficinas, entre outras ações que promoveram debates e a divulgação das experiências dos professores possibilitando melhoria do ensino, da pesquisa e da extensão universitária. É relevante destacar, entre as ações, o projeto RIU, cujo enfoque é a formação docente. E, ainda, o portfólio virtual com os resultados dos projetos, processos e recursos educacionais de livre acesso à comunidade acadêmica da UnB e fora dela. Esse espaço possibilitou e continua permitindo a reaplicação de experiências inovadoras de ensino e aprendizagem ativa do local para o global.

\section{REFERÊNCIAS}

[1] ALMEIDA, M. E. B.; PRADO, M. E. B. B. Integração tecnológica, linguagem e representação. Salto para o Futuro. TV Escola. $2006 . \quad$ Disponível em: http://webeduc.mec.gov.br/midiaseducacao/material/introdutorio/pdf/integracao_tecnologica.pdf. Acesso em: 10 maio 2020.

[2] BACICH, L.; MORAN, J. Aprender e ensinar com foco na educação híbrida. Revista Pátio, Porto Alegre, n. 25, p.45-47, jun. 2015. Disponível em: http://www2.eca.usp.br/moran. Acesso em: 10 maio 2020.

[3] BACICH, L.; TANZI NETO, A.; TREVISANI, F. de M. (Orgs.) Ensino Híbrido: Personalização e Tecnologia na Educação. Porto Alegre: Penso, 2015.

[4] BARDIN, L. Análise de conteúdo. São Paulo: Edições 70, 2011.

[5] BARRON, B. Learning ecologies for technological fluency in a technology-rich community. Journal of Educational Computing Research, n. 31, p. 1-37, 2004.

[6] BEHRENS, M. A. A prática pedagógica e o desafio do paradigma emergente. Revista Brasileira de Estudos pedagógicos, Brasília, v. 80, n. 196, p. 383-403, set./dez. 1999. Disponível em: http://rbep.inep.gov.br/index.php/rbep/article/view. Acesso em: 10 maio 2020.

[7] BOLL, C. I. Enunciação estética juvenil em vídeos escolares no YouTube. 117 f. Tese (Doutorado em Educação) - Faculdade de Educação, Universidade Federal do Rio Grande do Sul, Porto Alegre, 2013. Disponível em: https://www.lume.ufrgs.br/handle/10183/70596 Acesso em: 10 maio 2020.

[8] CAVALLO, D. at al. Inovação e Criatividade na Educação Básica: dos conceitos ao ecossistema. Revista Brasileira de Informática na Educação. Porto Alegre, v. 24, n. 2, p. 143-161, 2016.

[9] COLL, C. El currículo escolar en el marco de la nueva ecología del aprendizaje. Aula de innovación educativa. n. 219, p. 31-36, fev. 2013.

[10] __. Aprender y enseñar con las TIC: expectativas, realidad y potencialidades. In:

[11] CARNEIRO, R.; TOSCANO, J.C.; DÍAZ, T. (Coords.). Los desafíos de las TIC para el cambio educativo. Madrid: OEI/Fundación Santillana. 2009, p. 113-126.

[12] FERREIRA, G. A. Criatividade e inovação: conceitos e reflexões. Gestão \& Resultados. Folha Vitória, 5 nov. 2012. Disponível

Em:

https://www.folhavitoria.com.br/economia/blogs/gestaoeresultados/2012/11/05/criatividade-e-inovacaoconceitos-e-reflexoes/. Acesso em: 10 maio 2020.

[13] FULLAN, M. The new meaning of educational change. London: Routledge, 2007.

[14] FERREIRA, G. A. Criatividade e inovação:- conceitos e reflexões. Gestão \& Resultados. Folha Vitória, 5 nov. 2012. Disponível em:

https://www.folhavitoria.com.br/economia/blogs/gestaoeresultados/2012/11/05/criatividade-e-inovacao- 
conceitos-e-reflexoes/. Acesso em: 10 maio 2020.

[15] GHEDIN, E.; FRANCO, M. A. S. Questões de método na construção da pesquisa em educação. São Paulo, Cortez, 2008.

[16] HORN, M.; STAKER, H. Blended: usando a inovação disruptiva para aprimorar a educação. Porto Alegre: Penso. 2015.

[17] LAKATOS, E. M. MARCONI, M. De A. Técnicas de pesquisa : planejamento e execução de pesquisas, amostragens e técnicas de pesquisas, elaboração, análise e interpretação de dados. 5ed. São Paulo: Atlas, 2002.

[18] LÈVY, P. O futuro da internet: em direção a uma ciberdemocracia planetária. São Paulo: Paulus, 2010.

[19] LÉVY, P. Cibercultura. São Paulo: Editora 34, 1999.

[20] LIBEDINSKY, M. La innovación en la enseñanza como resolución de problemas. IEARN 2014, Fundación Educación, Educación-Tecnología -Innovación, p. 1-10, 1ํjul. 2014. Disponível em: https://www.researchgate.net/publication/263788448_

La_innovacion_en_la_ensenanza_como_resolucion_de_problemas_wwwiearn2014org_. Acesso em: 25 maio 2020.Acesso em: 20 abr. 2020.

[21] MINAYO, M. C. de S. (org.). Pesquisa Social. Teoria, método e criatividade. 18 ed. Petrópolis: Vozes, 2001.

[22] MORAN, J. M. Metodologias ativas para uma aprendizagem mais profunda. Blog ECA-USP, 2013. Disponível em: http://www2.eca.usp.br/moran/wp-content/uploads/2013/12/metodologias_moran1.pdf. Acesso em: 10 maio 2020.

[23] _. Tecnologias digitais para uma aprendizagem ativa e inovadora. Blog ECA-USP, 2018. Disponível em: http://www2.eca.usp.br/moran/wp-content/uploads/2017/11/tecnologias_moran.pdf. Acesso em: 10 maio 2020.

[24] MORAN, J. M. et al. Novas tecnologias e mediação pedagógica. 6. ed. Campinas: Papirus, 2000.

[25] MORAN, J. M. Metodologias ativas e modelos híbridos na educação. IN: YAEGASHI, Solange e outros (Orgs). Novas Tecnologias Digitais: Reflexões sobre mediação, aprendizagem e desenvolvimento. Curitiba: CRV, 2017, p.2335. 2018. Disponível em: https://www2.unicentro.br/proen/files/2018/08/Metodologias_Ativas.pdf. Acesso em: 10 maio 2020.

[26] MALDONATO, M.; DELL'ORCO, S. Criatividade, pesquisa e inovação: o caminho surpreendente da descoberta. Boletim Técnico do SENAC, Rio de Janeiro, v. 36, n.1, jan./abr. 2010. Disponível: https://www.bts.senac.br/bts/article/view/223/206. Acesso em: 10 maio 2020.

[27] NÓVOA, A. Formação de professores e trabalho pedagógico. Lisboa: Educa, 2002.

[28] PROGRAMA APRENDIZAGEM PARA 0 3ํ MILÊNIO - A3M. Projetos. Universidade de Brasília. 2019. Disponível em: https://www.a3m.cead.unb.br/projetos/. Acesso em: 10 maio 2020.

[29] PROJETO ROTAS DE INOVAÇÃO UIVERSITÁRIA - RIU, 2019.

[30] PRENSKY, Marc. Entrevista para a Milênio. Não podemos forçar os jovens a fazer o que foi bom para nós. Ideias do Milênio. Consulto Jurídico - Conjur. 2 jan. 2018. Disponível em: https://www.conjur.com.br/2018-jan02/embargada-milenio-marc-prenskyconsultor-educacao.Acesso em: 10 maio 202020.

[31] SHARPLES, M. Seamless learning despite context. In: WONG, L.H.; MILRAD,

[32] M.; SPECHT, M. (Eds.). Seamless learning in the age of mobile connectivity. Singapore: Springer Science+Business Media, 2015, p. 41-55.

[33] TAKAHASHI, T. (Org.). Sociedade da informação no Brasil: livro verde. Brasília: Ministério da Ciência e Tecnologia, 2000.

[34] THIOLLENT, M. Metodologia da pesquisa-ação. São Paulo: Cortez, 2011.

[35] UNIVERSIDADE E BRASÍLIA (UnB). Edital CEAD/DEG/DPI n 01/2019.

[36] UNIVERSIDADE DE BRASÍLIA (UnB). CEAD e DEG lançam edital para o Programa A3M. 23 abr. 2018. Disponível em: https://www.a3m.cead.unb.br/noticias/cead-e-deg-lancam-edital-para-o-programa-a3m. Acesso em: 05 maio 2020 


\section{Capítulo 4}

O Papel dos licenciados em computação no apoio ao ensino remoto em tempos de isolamento social devido à pandemia da COVID-19

\section{Sidnei Renato Silveira}

\section{Cristiano Bertolini}

Fábio José Parreira

Guilherme Bernardino da Cunha

Nara Martini Bigolin

Resumo: Este artigo apresenta algumas alternativas tecnológicas que podem ser adotadas para apoiar o ensino remoto durante o período de isolamento social, devido à pandemia da COVID-19, com o apoio de Licenciados em Computação. A UFSM Universidade Federal de Santa Maria oferta, no âmbito da UAB - Universidade Aberta do Brasil, o Curso de Licenciatura em Computação na modalidade a distância. 0 Curso é ofertado, atualmente, em cinco polos da UAB no Estado do RS. 0 perfil dos egressos deste curso envolve a formação de professores que poderão atuar em diferentes níveis de ensino, como docentes e/ou como parceiros dos docentes de diferentes áreas do conhecimento, visando ao desenvolvimento e aplicação de diferentes TDICs Tecnologias Digitais da Informação e da Comunicação no contexto educacional. 0 perfil dos egressos pretendido pelo curso, alicerçado pelo Projeto Pedagógico do mesmo, permite a inserção em diferentes modalidades de ensino incluindo, também, o ensino remoto.

Palavras-Chave: Pandemia da COVID-19. Ensino Remoto. Licenciatura em Computação. 


\section{INTRODUÇÃO}

Neste ano de 2020, devido ao isolamento social para evitar o contágio do coronavírus, as instituições de ensino estão com suas atividades presenciais suspensas, levando em conta o elevado risco de contágio nestes ambientes (CORADINI, 2020). No Estado do RS (Rio Grande do Sul), o Decreto 55.118, de 19 de março de 2020, determinou a suspensão das atividades presenciais nos estabelecimentos de ensino públicos estaduais (medida que segue estendida até os dias atuais, em fins do mês de maio) (RIO GRANDE DO SUL, 2020). As instituições privadas, de diferentes níveis, bem como as escolas públicas municipais também adotaram esta suspensão, visando a achatar a curva do contágio do novo coronavírus.

Desta forma, as atividades ligadas aos processos de ensino e de aprendizagem estão sendo desenvolvidas de diferentes formas, a distância. Algumas escolas estão solicitando que os pais dos alunos busquem, semanalmente, atividades que são entregues de forma impressa. Outras estão utilizando recursos das TDICs (Tecnologias Digitais da Informação e da Comunicação), tais como e-mail, WhatsApp, Google ClassRoom, GoogleMeet, BigBlueButton e AVAs (Ambientes Virtuais de Aprendizagem), entre outros (COSTA, 2020; GOOGLE, 2020a; GOOGLE, 2020b; MOODLE.ORG, 2020; SPONCHIATO, 2020).

A UFSM - Universidade Federal de Santa Maria, adota o AVA Moodle e decidiu não suspender o calendário acadêmico do 1o semestre de 2020, adotando o regime denominado REDE (Regime de Exercícios Domiciliares Especiais), de acordo com as instruções normativas da PROGRAD (Pró-Reitoria de Graduação) 02/2020/PROGRAD/UFSM e 03/2020/PROGRAD/UFSM (UFSM, 2020a; UFSM, 2020b). Sendo assim, a UFSM sugeriu aos seus professores que adotassem recursos de TDICs em seu fazer pedagógico. Entretanto, grande parte dos docentes não possuía, até então, nenhuma experiência ou formação para a utilização destas tecnologias, para dar conta de atividades realizadas a distância.

Esta realidade da falta de formação não é exclusiva das Instituições de Ensino Superior. Escolas de todos os níveis de ensino, tanto públicas quanto privadas, também precisaram repensar o seu fazer pedagógico, para dar conta da suspensão das atividades presenciais, sem prejudicar o andamento do ano letivo. Uma pesquisa desenvolvida pelo Instituto Península mostra que $90 \%$ dos docentes pesquisados não tinha desenvolvido nenhuma atividade na modalidade a distância e que $55 \%$ destes docentes não tinha participado de nenhuma atividade formativa para aplicar as TDICs (INSTITUTO PENÍNSULA, 2020).

0 que se verifica, por meio da observação do trabalho desenvolvido pelos docentes, é que a maioria não estava preparada para desenvolver as atividades mediadas pelas TDICs e, além disso, não estava preparada para definir e adotar uma metodologia que não replicasse o modelo tradicional de ensino, baseado em aulas expositivas (DEMO, 2011; DEMO, 2014) e exercícios repetitivos, apenas utilizando as TDICs como meio para transmissão do conhecimento. Esta observação está alicerçada no contato com os alunos do Curso de Licenciatura em Computação (ofertado na modalidade de EaD - Educação a Distância) e no contato com alunos e professores do Curso de Bacharelado em Sistemas de Informação (ofertado de forma presencial), ambos cursos da UFSM (UFSM, 2020c; UFSM, 2020d).

Diferentes reportagens e pesquisas, em todo o Brasil, têm relatado as dificuldades dos professores para desenvolverem as atividades a distância, além do fato de que o volume de atividades tornou-se maior. Outra constatação é de que os professores não estão seguindo um modelo padronizado, ou seja, algumas instituições não definem quais ferramentas devem ser aplicadas, nem mesmo como devem ser aplicadas. Desta forma, cada docente está buscando alternativas para dar conta das suas atividades pedagógicas nessa realidade atual (FRANCO, 2020; GODOY, 2020; SAMPAIO, 2020; TENENTE, 2020).

Neste contexto, este artigo apresenta alternativas para que os Licenciados em Computação possam atuar como disseminadores da aplicação das TDICs como ferramentas de apoio aos processos de ensino e de aprendizagem, especialmente no que diz respeito ao ensino remoto, adotado atualmente em meio ao isolamento social provocado pela pandemia da COVID-19.

0 artigo está organizado como segue: a seção 2 apresenta informações sobre o Curso de Licenciatura em Computação, ofertado na modalidade de EaD, pela UFSM, no âmbito da UAB - Universidade Aberta do Brasil, destacando os objetivos do mesmo, bem como o perfil do egresso pretendido. A seção 3 apresenta uma discussão envolvendo alternativas que podem ser aplicadas pelas instituições de ensino, com o apoio dos Licenciados em Computação, para dar conta das atividades relacionadas aos processos de ensino e de aprendizagem, alicerçadas nas TDICs. Encerrando o artigo são apresentadas as considerações finais e as referências empregadas. 


\section{O CURSO DE LICENCIATURA EM COMPUTAÇÃO}

O Curso de Licenciatura em Computação da UFSM - Campus Frederico Westphalen - RS é ofertado desde o ano de 2017, na modalidade a distância, no âmbito da UAB. O curso foi criado por docentes do Departamento de Tecnologia da Informação no ano de 2013 e submetido ao edital da CAPES no início do ano de 2015 (Edital 075/2014) (CAPES, 2014). Conforme o edital, o curso deveria ter iniciado em 2016 mas, devido a problemas orçamentários, o mesmo iniciou no 1o semestre de 2017. Foram ofertadas 125 vagas, sendo 25 em cada um dos polos da UAB, todos no Estado do Rio Grande do Sul: Cruz Alta, Palmeira das Missões, Sarandi, Seberi e Três Passos (UFSM, 2020c).

0 curso iniciou suas atividades acadêmicas em março de 2017, contanto com 109 alunos matriculados, 8 tutores (sendo 5 tutores presenciais - 1 em cada polo de oferta e 3 tutores virtuais), além de 6 docentes formadores, que assumiram as disciplinas relativas ao $1^{\underline{0}}$ semestre do currículo. 0 currículo do curso, bem como o Projeto Pedagógico completo, podem ser encontrados no site da UFSM - Campus Frederico Westphalen - RS (UFSM, 2020c).

Antes mesmo de o curso ser iniciado, tendo-se em vista a publicação da Resolução 2/2015 do Conselho Nacional de Educação (MEC, 2015), foi necessário adequar o Projeto Pedagógico do Curso, para atender, entre outros aspectos, às seguintes normas da resolução: 1) estruturação do currículo em núcleos: formação geral, aprofundamento e diversificação de estudos e estudos integradores; 2) 400 horas destinadas ao Estágio Supervisionado e 3) inclusão de disciplinas voltadas à Educação Especial e Diversidades Étnico-Racial, de Gênero, Sexual e Religiosa. 0 Estágio Supervisionado é desenvolvido nos 5oㅡ, 6ํㅜ 7으 e 8o semestres respectivamente, nas disciplinas de Estágio Supervisionado I (90h), II (90h), III (105h) e IV (120h). Os temas envolvendo a diversidade são discutidos de forma transversal e, também, na disciplina de Tópicos Especiais em Diversidade Cultural.

O Curso possui 3.320 horas, assim distribuídas: 3030 horas de disciplinas obrigatórias (incluindo as 405 horas destinadas ao Estágio Supervisionado), 90 horas de Disciplinas Complementares de Graduação (Optativas) e 200 horas de Atividades Complementares. Ainda em 2016, antes de iniciar as atividades acadêmicas do curso, foram elaborados os e-books das disciplinas relativas ao $1^{\underline{0}}$ semestre do currículo (UFSM, 2020d), sendo eles: Metodologia da Aprendizagem em EaD, Lógica Matemática, Aplicativos Computacionais aplicados à Educação, Informática Básica, Fundamentos Filosóficos e Sociológicos da Educação e Laboratório de Montagem e Manutenção. Os e-books que já possuem o ISBN (International Standard Book Number) estão disponíveis para download, gratuitamente, no site do Núcleo de Tecnologia Educacional (NTE) da UFSM, órgão que presta apoio às atividades dos cursos ofertados no âmbito da UAB na UFSM (NTE, 2020).

Na UFSM, os cursos ofertados no âmbito da UAB utilizam o Ambiente Virtual de Aprendizagem (AVA) Moodle. O NTE é o órgão responsável pelo gerenciamento do AVA, realizando o cadastro das disciplinas, professores formadores, tutores e alunos. Todos os tutores (presenciais e/ou virtuais) devem, obrigatoriamente, realizar a formação para uso do AVA, ministrada pelo NTE.

O objeto de estudo do curso envolve conceitos fundamentais da Ciência e da Tecnologia da Computação; teorias relativas à aprendizagem e sua aplicação em ambientes informatizados de aprendizagem; processos de ensino e de aprendizagem nas áreas de computação e pedagogia (UFSM, 2020c).

Por meio da aquisição de capacidades relacionadas com o desempenho da prática pedagógica, para o exercício da docência voltada à diversidade, objetiva-se licenciar professores na área de informática para atuarem no Ensino Fundamental, Médio, Técnico, em empresas de consultoria e assessoria em informática, empresas de desenvolvimento de software educacional e empresas que utilizam a TDICs para a capacitação de funcionários (UFSM, 2020c).

Os objetivos do Curso de Licenciatura em Computação da UFSM/UAB são (UFSM, 2020c):

- Qualificar profissionais capazes de atuarem em empresas que utilizam a tecnologia da informação para capacitação de recursos humanos;

- Qualificar licenciados na área de Computação como agentes capazes de promover um espaço para a interdisciplinaridade, a comunicação e a articulação, entre as diversas disciplinas e áreas do conhecimento do currículo escolar, ou seja, fomentar competências dentro das áreas;

- Qualificar educadores para o ensino de Computação em instituições que introduzirem a computação em seus currículos, como matéria de formação. 
Estes educadores devem desenvolver diferentes capacidades, tais como: analisar as atividades desenvolvidas nas instituições em que estejam inseridos, interagindo de forma ativa e solidária com a comunidade; cooperar no processo de discussão, planejamento, execução de ações pedagógicas e avaliação do projeto pedagógico da instituição; compreender o contexto socioeconômico e cultural no qual se encontram, propondo resolução dos desafios encontrados; atuar nas áreas de serviço e apoio escolar ou em outras áreas nas quais sejam previstos conhecimentos pedagógicos e de Computação (UFSM, 2020c).

0 perfil do egresso Licenciado em Computação está baseado na Resolução 5/2016 do Conselho Nacional de Educação e no artigo 5o da Resolução CNE/CP 2/2015, que propõe as Diretrizes Curriculares Nacionais para os cursos de graduação em Computação. Segundo este parecer, os cursos de Licenciatura em Computação têm como objetivo principal preparar professores para formar cidadãos com competências e habilidades necessárias para conviver, prosperar em um mundo cada vez mais tecnológico e global, e que contribuam para promover o desenvolvimento econômico e social de nosso país. A introdução do pensamento computacional e algorítmico na educação básica fornece os recursos cognitivos necessários para a resolução de problemas, transversal a todas as áreas do conhecimento. As ferramentas de educação assistida por computador e os sistemas de EaD tornam a interação entre ensino e aprendizagem mais prazerosa, autônoma e efetiva, pois introduzem princípios e conceitos pedagógicos na interação humanocomputador. Essas ferramentas são desenvolvidas com a participação de Licenciados em Computação. Genericamente, todo sistema computacional com funcionalidade pedagógica ou que necessita de assistência para seu uso, requer a participação dos Licenciados em Computação (MEC, 2015; MEC, 2016).

Dessa forma, o Curso de Licenciatura em Computação tem, por objetivo, a formação de professores da área de informática, capazes de tratar os conteúdos da ciência da computação, necessários e significativos para o Ensino Fundamental, Médio e Técnico e, também, para atuarem em empresas de consultoria e assessoria em informática, empresas de desenvolvimento de software educacional, empresas que utilizam a Tecnologia da Informação para capacitação de funcionários.

\section{ALTERNATIVAS PARA OS LICENCIADOS EM COMPUTAÇÃO APOIAREM O ENSINO REMOTO}

Antes de iniciarmos a discussão sobre as alternativas de atuação do Licenciado em Computação, vamos conceituar ensino remoto e $\mathrm{EaD}$, visando a compreender sua diferenciação. 0 ensino remoto, devido à pandemia da COVID-19, está sendo aplicado como forma emergencial, para dar conta de uma situação até então inesperada, ou seja, os Projetos Pedagógicos das Instituições de Ensino e de seus respectivos cursos não foram construídos para dar conta da modalidade de $\mathrm{EaD}$, a fim de estruturar o currículo e os processos de ensino e de aprendizagem nesta modalidade diferenciada. Desta forma, os professores estão apenas utilizando as TDICs como meio, mantendo as mesmas metodologias de ensino utilizadas no ensino presencial, baseadas, quase que em sua totalidade, na transmissão de conhecimentos, por meio de aulas expositivas e exercícios para fixação do conteúdo.

A EaD, por sua vez, envolve todo um projeto educacional diferenciado, com tutores, ambientes virtuais, utilização de Objetos de Aprendizagem (PARREIRA et al., 2018; PEREIRA et al., 2017) e diferentes metodologias de ensino, para dar conta da interação necessária no ambiente virtual. A EaD deve privilegiar a interação mediada por diferentes tecnologias, tais como a Internet, com apoio pedagógico e de infraestrutura tecnológica para os professores e para os alunos. Sendo assim, o que os docentes de diferentes instituições de ensino estão desenvolvendo, no momento, é o ensino remoto e não a EaD propriamente dita, até mesmo porque a maioria das instituições de ensino, que atuam na modalidade presencial, não possuem infraestrutura tecnológica para dar suporte às atividades em EaD e, também, não prepararam seus docentes para atuarem neste contexto.

Neste sentido, as alternativas aqui discutidas envolvem a atuação dos Licenciados em Computação no âmbito do ensino remoto. Atualmente, os alunos do Curso de Licenciatura em Computação estão cursando as disciplinas relativas ao $7^{\circ}$ s semestre do curso, incluindo a disciplina de Estágio Supervisionado III. Esta disciplina visa à realização de atividades de formação docente para aplicação de TDICs. Esta é uma das primeiras alternativas para que os futuros Licenciados em Computação possam, além de realizarem a prática prevista no Estágio Supervisionado, colaborarem com docentes de diferentes áreas do conhecimento e de diferentes níveis educacionais e instituições de ensino, a utilizarem as TDICs para dar conta do ensino remoto. Entre os diferentes projetos de estágio que estão em desenvolvimento (são 39 alunos cursando a disciplina de Estágio Supervisionado III), destacam-se propostas para a formação de docentes para a utilização de TDICs e para a aplicação de ferramentas para o desenvolvimento computacional, tais como a ferramenta Scratch (SCRATCH BRASIL, 2020). 
Além do Estágio Supervisionado, neste semestre os alunos iniciaram as atividades relacionadas ao TCC (Trabalho de Conclusão de Curso). Ao escolherem os temas de seus trabalhos, devido ao isolamento social decorrente da pandemia da COVID-19, vários alunos decidiram desenvolver pesquisas voltadas à solução dos problemas que envolvem o ensino remoto neste contexto. Sendo assim, alguns trabalhos estão relacionados: 1) ao uso do WhatsApp como ferramenta de apoio aos processos de ensino e de aprendizagem; 2) formação docente para o uso de TDICs; 3 ) o uso de vídeoaulas nos processos de ensino e de aprendizagem e 4) o uso de AVAs no contexto escolar.

Os Licenciados em Computação possuem formação adequada para atender a diferentes necessidades de aplicação das TDICs nos espaços educacionais, podendo atuar em equipes de desenvolvimento de softwares educacionais, suporte à aplicação de diferentes ferramentas (tais como os AVAs), suporte à aplicação de metodologias de ensino inovadoras, apoiadas pelas tecnologias, entre outras possibilidades. Para tanto, o currículo possui disciplinas da área de Educação, bem como da área de Computação, tais como Didática Geral, Metodologia do Ensino e da Aprendizagem em Informática, Metodologia da Aprendizagem em EaD e Jogos Educacionais, entre outras.

As disciplinas relacionadas às metodologias, tais como as de Metodologia da Aprendizagem em EaD (PEREIRA et al., 2017) e de Metodologia do Ensino e da Aprendizagem em Informática (SILVEIRA et al., 2019), propiciam um embasamento teórico-prático para que os futuros Licenciados em Computação possam auxiliar no desenvolvimento de projetos pedagógicos que incentivem a aplicação de TDICs na modalidade de EaD, privilegiando a interação e o feedback constante, além da adoção de metodologias inovadoras de aprendizagem, tais como a sala de aula invertida (BERGMANN, 2018).

A Sala de Aula invertida prevê que os alunos desenvolvam, como tema de casa, atividades mais simples, tais como a leitura de textos introdutórios ou conceituais de cada assunto que será abordado. Bergmann (2018) propõe que, ao invés de leituras, os alunos assistam a vídeoaulas, preferencialmente desenvolvidas pelos professores. Posteriormente, na sala de aula presencial ou apoiados pelas TDICs (como é o caso atual, do ensino remoto), os alunos podem discutir os conceitos estudados nas vídeoaulas e interagirem com o professor e com os colegas. Os Licenciados em Computação podem auxiliar os colegas professores para desenvolverem vídeoaulas com diferentes ferramentas e, posteriormente, a interagirem com seus alunos via Internet.

Além da Sala de Aula invertida, os Licenciados em Computação podem apoiar a adoção de outras metodologias inovadoras, tais como a Aprendizagem Baseada em Problemas (PBL Problem Based Learning) ou a Aprendizagem Baseada em Projetos, por exemplo. Neste caso, diferentes softwares educacionais podem ser utilizados para auxiliar alunos e professores no desenvolvimento de suas atividades, desde AVAs até simuladores e laboratórios virtuais (SILVEIRA et al., 2019).

Uma das ferramentas utilizadas no curso é a Ardora, que permite a criação de diferentes atividades lúdicas. A ferramenta possui fácil utilização, além de ser disponibilizada de forma gratuita, sendo uma alternativa interessante para auxiliar docentes de diferentes áreas do conhecimento a utilizarem TDICs em suas aulas (MATANZA, 2020; PEREIRA et al., 2017).

Com relação ao uso de ferramentas que permitem o desenvolvimento de atividades a distância, tais como os AVAs, os alunos do Curso de Licenciatura em Computação possuem experiência com o uso do Moodle (AVA adotado oficialmente pela UFSM). Além disso, a partir dos diferentes conteúdos estudados durante as disciplinas do curso, os mesmos estão aptos a auxiliar na instalação, utilização, treinamento e efetiva aplicação de diferentes AVAs no contexto educacional. A atuação na modalidade a distância está contemplada no Projeto Pedagógico do Curso, quando se coloca que o Licenciado em Computação poderá atuar na implantação de metodologias e infraestrutura computacional para o desenvolvimento de atividades ligadas à EaD, bem como no desenvolvimento de softwares educacionais, tais como AVAs, jogos educacionais e outras ferramentas que possam ser aplicadas no ambiente escolar, como ferramentas de apoio aos processos de ensino e de aprendizagem (UFSM, 2020c).

Entre as competências pretendidas pelo Licenciado em Computação, de acordo com o Projeto Pedagógico do Curso, destaca-se a de desenvolver a capacidade de liderança, de gestão, de colaboração, de trabalho em equipe e de visão humanística dos problemas, com a consciência ética do papel do profissional e educador na sociedade, no cenário regional, nacional e global. Neste sentido, o momento emergencial devido à pandemia da COVID-19 abre espaço para que nossos alunos possam atuar em atividades ligadas às diferentes instituições de ensino nas cidades onde residem, sejam estas atividades relacionadas ao Estágio Supervisionado ou não, bem como ao Trabalho de Conclusão de Curso, conscientes de sua inserção na comunidade. 
Apesar de o curso ser ofertado em polos distribuídos em cinco cidades do RS, a partir de um levantamento realizado no início do curso, verificou-se que os alunos residem em dezessete diferentes municípios. Além disso, ao definirem as instituições de ensino para realização do Estágio Supervisionado, os alunos atuaram e/ou estão atuando em trinta diferentes instituições de ensino, públicas ou privadas. Estes números mostram a inserção dos futuros Licenciados em Computação na comunidade, um passo importante para que a construção do conhecimento extrapole o contexto universitário.

\section{CONSIDERAÇÕES FINAIS}

A formação do Licenciado em Computação, especialmente do curso ofertado pela UAB/UFSM, envolve o desenvolvimento de diferentes competências e habilidades profissionais, tais como a aplicação de TDICs nos processos de planejamento e gestão do ensino e da aprendizagem em diferentes instituições de ensino. Cabe destacar que, neste momento emergencial, devido à pandemia do COVID-19, a aplicação do ensino remoto tem sido, em grande parte, realizada a partir do uso das TDICs como ferramenta de apoio, baseando as atividades docentes na metodologia tradicional de ensino, focada na transmissão de conhecimento, em aulas expositivas e exercícios para fixação do conteúdo. Entretanto, o que se espera do Licenciado em Computação é a utilização de novas metodologias e tecnologias educacionais nos processos de ensino e de aprendizagem, tais como as metodologias ativas. Estas metodologias posicionam o aluno como centro do processo de aprendizagem, como construtor do seu próprio conhecimento (CARRETERO, 2002; FRANCO, 2004; SILVEIRA et al., 2019). Neste contexto, o professor deixa de ser o detentor do conhecimento e passa a compartilhá-lo com seus alunos.

Outra questão importante diz respeito à atuação contextualizada dos Licenciados em Computação. Estes profissionais devem estar atentos às demandas das instituições de ensino, buscando apoiar a aplicação das TDICs nos diferentes contextos educacionais, tais como no momento atual, que envolve o isolamento social devido à pandemia da COVID-19.

o Licenciado em Computação é um profissional docente que incorpora competências, saberes e habilidades de criatividade e inovação, de cooperação e de trabalho em equipe, de gestão e tomada de decisões, de aquisição e produção de conhecimentos, de expressão e comunicação, não sendo somente reprodutor de conhecimentos já estabelecidos. Trata-se de um profissional capaz de desempenhar um papel transformador da realidade de forma a contribuir para o desenvolvimento da ciência, tecnologia, arte, cultura e o trato da diversidade; promover a formação de cidadãos para uma sociedade fundada no conhecimento, no trabalho e na necessária reflexão sobre valores éticos, de justiça e de integração social (SBC, 2018).

Além disso, a SBC (Sociedade Brasileira de Computação) tem realizado uma série de esforços para incluir a Computação na BNCC (Base Nacional Comum Curricular), por meio do estudo do pensamento computacional (SBC, 2017; SBC, 2018). 0 pensamento computacional refere-se à capacidade de resolver problemas por meio da construção de algoritmos. A proposta da SBC vai além, buscando incluir o estudo da computação para estimular o desenvolvimento do raciocínio lógico e, também, incluir os alunos no mundo digital. Esta é outra área que pode ser explorada pelos Licenciados em Computação, estimulando docentes de diferentes áreas do conhecimento a explorarem os conceitos computacionais, relacionando-os as suas disciplinas.

\section{REFERÊNCIAS}

[1] Bergmann, J. Aprendizagem Invertida para resolver o Problema do Dever de Casa. Porto Alegre: Penso, 2018.

[2] CAPES, Coordenação de Aperfeiçoamento de Pessoal de Nível Superior. Edital 75/2014: Oferta de vagas em cursos superiores na modalidade a distância no âmbito do Sistema Universidade Aberta do Brasil. Brasília: CAPES. Disponível em: https://www.capes.gov.br/images/stories/download/editais/Edital-075-2014-UAB.pdf. Acesso em maio, 2020.

[3] CARRETERO, M. Construtivismo e Educação. Porto Alegre: Artes Médicas, 2002.

[4] CORADINI, L. Ensino remoto durante crise pandêmica agrava as desigualdades. Sul 21, 2020. Disponível em: https://www.sul21.com.br/opiniaopublica/2020/05/ensino-remoto-durante-crise-pandemica-agrava-asdesigualdades-por-lucas-coradini/. Acesso em maio, 2020. 
[5] COSTA, D. Estabelecido plano de ações para as escolas estaduais durante o período de suspensão das aulas. Disponível em: https://educacao.rs.gov.br/seduc-estabelece-plano-de-acoes-para-as-escolas-estaduais-durante-operiodo-de-suspensao-das-aulas. Acesso em abril, 2020.

[6] DEMO, P. Educar pela Pesquisa. 9. ed. Campinas: Autores Associados, 2011.

[7] DEMO, P. Ser Professor é Cuidar que o Aluno Aprenda. Porto Alegre: Mediação, 2014.

[8] FRANCO, S. R. K. O Construtivismo e a Educação. Porto Alegre: Artes Médicas, 2004.

[9] FRANCO, G. Coronavírus: professores falam dos desafios e vantagens de trabalhar em casa. Disponível em: https://educador.brasilescola.uol.com.br/noticias/coronavirus-professores-falam-dos-desafios-e-vantagens-detrabalhar-em-casa/33270.html. Acesso em maio, 2020.

[10] GODOY, J. Professores e alunos falam sobre desafios e dificuldades de aulas online durante pandemia em MS. Portal G1 MS. 21 de maio de 2020. Disponível em: https://g1.globo.com/ms/mato-grosso-dosul/noticia/2020/05/21/professores-e-alunos-falam-sobre-desafios-e-dificuldades-de-aulas-online-durantepandemia-em-ms.ghtml. Acesso em maio, 2020.

[11] GOOGLE. Google ClassRoom. Disponível em: https://play.google.com/store/apps/details?id=com.google.android.apps.classroom\&hl=pt_BR. Acesso em maio de 2020a.

[12] GOOGLE. Google Meet. Disponível em: https://meet.google.com/. Acesso em maio, 2020b.

[13] INSTITUTO PENÍNSULA. Sentimento e percepção dos professores brasileiros nos diferentes estágios do Coronavírus no Brasil. Disponível em: https://www.institutopeninsula.org.br/pesquisa-sentimento-e-percepcao-dosprofessores-nos-diferentes-estagios-do-coronavirus-no-brasil/. Acesso em maio de 2020.

[14] MATANZA, J. M. B. Ardora. 2020. Disponível em: http://webardora.net/index.htm. Acesso em maio, 2020.

[15] MEC, Ministério da Educação. Resolução CNE/CP 2/2015: Define as Diretrizes Curriculares Nacionais para a formação inicial em nível superior (cursos de licenciatura, cursos de formação pedagógica para graduados e cursos de segunda licenciatura) e para a formação continuada. Brasília: Conselho Nacional de Educação - CNE/Ministério da Educação - $\quad$ MEC. http://portal.mec.gov.br/index.php?option=com_docman\&view=download\&alias=136731-rcp002-151\&category_slug=dezembro-2019-pdf\&Itemid=30192. Acesso em maio, 2020.

[16] MEC, Ministério da Educação. Resolução CNE/CES 5/2016: Institui as Diretrizes Curriculares Nacionais para os cursos de graduação na área da Computação. Brasília: Conselho Nacional de Educação - CNE - Câmara de Educação $\begin{array}{llll}\text { Superior } & - & \text { CES. } & \text { Disponível }\end{array}$ http://portal.mec.gov.br/index.php?option=com_docman\&view=download\&alias=52101-rces005-16pdf\&category_slug=novembro-2016-pdf\&Itemid=30192. Acesso em maio, 2020.

[17] MOODLE.ORG. Big Blue Button. Disponível em: https://moodle.org/plugins/mod_bigbluebuttonbn. Acesso em maio, 2020.

[18] NTE, Núcleo de Tecnologia Educacional. Materiais Didáticos. Núcleo de Tecnologia Educacional. Santa Maria: NTE/UAB/UFSM. Disponível em: https://nte.ufsm.br/noticias/14-como-usar-o-moodle/118-material-didatico. Acesso em maio, 2020.

[19] PARREIRA, F. J.; FALKEMBACH, G. A. M.; SILVEIRA, S. R. Construção de Jogos Educacionais Digitais e Objetos de Aprendizagem: um estudo de caso empregando Adobe Flash, HTML 5, CSS, JavaScript e Ardora. Rio de Janeiro: Ciência Moderna, 2018.

[20] PEREIRA, A. S.; PARREIRA, F. J.; BERTAGNOLLI, S. C.; SILVEIRA. S. R. Metodologia da Aprendizagem em EaD. Santa Maria, RS: UAB/NTE/UFSM, 2017. Disponível em: https://repositorio.ufsm.br/handle/1/15809. Acesso em abril, 2020.

[21] RIO GRANDE DO SUL. Decreto 55.118/2020: Estabelece medidas complementares de prevenção ao contágio pelo COVID-19 (novo Coronavírus) no âmbito do Estado. Disponível em: https://www.estado.rs.gov.br/upload/arquivos//decreto-55118.pdf. Acesso em maio, 2020.

[22] SAMPAIO, C. Professores, pais e alunos apontam dificuldades e limitações do ensino a distância. Brasil de Fato. 4 de maio de 2020. Disponível em: https://www.brasildefato.com.br/2020/05/04/professores-pais-e-alunosapontam-dificuldades-e-limitacoes-no-ensino-a-distancia. Acesso em maio, 2020.

[23] SBC. Sociedade Brasileira de Computação. Referenciais de Formação em Computação: Educação Básica. 2017. Disponível em: http://www.sbc.org.br/documentos-da-sbc/send/131-curriculos-de-referencia/1166-referenciais-deformacao-em-computacao-educacao-basica-julho-2017. Acesso em maio, 2019.

[24] SBC. Sociedade Brasileira de Computação. Diretrizes para o Ensino de Computação Básica. Documento Interno da Comissão de Educação Básica da SBC, 2018. 
[25] SCRATCH BRASIL. Você conhece o Scratch? Disponível em: http://www.scratchbrasil.net.br/index.php/sobre-o-scratch.html. Acesso em maio, 2020.

[26] SILVEIRA, S. R.; PARREIRA, F. J.; BIGOLIN, N. M.; PERTILE, S. L. Metodologia do Ensino e da Aprendizagem em Informática. Santa Maria: UAB/NTE/UFSM, 2019b. Disponível em: https://www.ufsm.br/orgaossuplementares/nte/wp-content/uploads/sites/358/2019/08/MD_Metodologia-do-Ensino-e-da-Aprendizagem-emInform\%C3\%A1tica.pdf. Acesso em maio de 2020.

[27] SPONCHIATO, D. Coronavírus: como a pandemia nasceu de uma zoonose. Disponível em: <https://saude.abril.com.br/medicina/coronavirus-pandemia-zoonose/> Acesso em abril, 2020.

[28] TENENTE, L. Sem Internet, merenda e lugar para estudar: veja obstáculos do ensino a distância na rede pública durante a pandemia de Covid-19. Portal G1, 05 de maio de 2020. Disponível em: https://g1.globo.com/educacao/noticia/2020/05/05/sem-internet-merenda-e-lugar-para-estudar-veja-obstaculosdo-ensino-a-distancia-na-rede-publica-durante-a-pandemia-de-covid-19.ghtml. Acesso em maio, 2020.

[29] UFSM. Universidade Federal de Santa Maria. Instrução Normativa 02/2020: Regula o regime de exercícios disciplinares especiais. 2020a. Disponível em: https://www.ufsm.br/wp-content/uploads/2020/03/IN-002-2020PROGRAD-UFSM.pdf. Acesso em abril, 2020a.

[30] UFSM. Universidade Federal de Santa Maria. Instrução Normativa 03/2020: Regula situações de estágios, atividades práticas, estágios e internatos na área de saúde, bem como situações de dificuldade de acesso a internet durante o Regime de Exercícios Domiciliares Especiais (REDE). 2020b. Disponível em: https://www.ufsm.br/unidades-universitarias/ce/2020/03/24/instrucao-normativa-n-03-2020-prograd-de-20-demarco-de-2020/. Acesso em abril, 2020b.

[31] UFSM. Universidade Federal de Santa Maria. Curso de Bacharelado em Sistemas de Informação. 2020c. Disponível em: https://www.ufsm.br/cursos/graduacao/frederico-westphalen/sistemas-de-informacao/. Acesso em maio, 2020c.

[32] UFSM. Universidade Federal de Santa Maria. Curso de Licenciatura em Computação EaD. 2020d. Disponível em: https://www.ufsm.br/cursos/graduacao/educacao-a-distancia/computacao/. Acesso em maio, $2020 \mathrm{~d}$. 


\title{
Capítulo 5
}

Categorização e análise de atividades avaliativas de um curso de Ciências Biológicas a distância

\author{
Otávio Vieira Sobreira Júnior \\ Francisco Wagner de Sousa Paula \\ Lydia Dayanne Maia Pantoja \\ Germana Costa Paixão
}

Resumo: As atividades propostas em um curso a distância devem ser pensadas não apenas como instrumento avaliativo, mas como ferramenta de interação e de motivação para aprender conteúdos e para aplicá-los em sua prática. Com base neste pensamento, este trabalho tem por objetivo promover uma análise sobre as diversas atividades solicitadas em um curso de licenciatura em Ciências Biológicas a distância quanto à natureza dos produtos pedagógicos solicitados, tipos de comunicação, de interação e categoria desse produto, sendo desenvolvida uma pesquisa do tipo descritiva, com abordagem qualitativa, tendo investigadas as atividades propostas aos alunos ingressantes no ano de 2012 e egressos no ano de 2016, que utilizaram o Ambiente Virtual de Aprendizagem - AVA Moodle® versão 2.7. No total foram analisadas 171 atividades avaliativas, que geraram 23 produtos, em sua maioria de categoria teórica, com grande destaque aos que utilizam o tipo de comunicação assíncrona e de interação individual. Os resultados permitem inferir que nesta turma os princípios da modalidade a distância foram bem contemplados por proporcionarem o desenvolvimento da autonomia como uma competência para que os alunos realizassem as atividades, tendo em vista serem contempladas suas necessidades e o respeito às suas particularidades de organização de tempo. Com o bom uso dos diversos tipos de ferramentas é possível criar nos alunos um sentimento de acolhimento, mas exige um planejamento eficaz e inovador para a criação e inserção de atividades diversificadas, que estimulem a construção do conhecimento em que os sujeitos possam contextualizar questões locais e globais do seu universo cultural e expressar-se contribuindo com o coletivo.

Palavras-chave: Educação a Distância, Atividades, Biologia. 


\section{INTRODUÇÃO}

O planejamento das atividades solicitadas no ensino a distância deve ser pautado por mecanismos que instiguem os alunos a pensar, a escrever e a resolver problemas. Neste ínterim, ao planejar as atividades, deve-se pensar naquelas em que se associem à formação teórico-prática do aluno, com ênfase na formação de professor, utilizando tecnologias que despertem no licenciando a capacidade de criticidade, contribuindo para formar cidadãos capazes de aprender a aprender, buscar novos conhecimentos e solucionar problemas (PASSOS, 2020).

E, é com vistas no processo ensino-aprendizagem destes alunos, que as atividades são solicitadas, mediante situações diversas, sempre as contextualizando dentro de um projeto pedagógico que contemple as especificidades da Educação a Distância - EaD, priorizando a inclusão de recursos tecnológicos que permitem graus diferenciados de interação. Destaca-se que os Ambientes Virtuais de Aprendizagem - AVA apresentam várias ferramentas que facilitam a comunicação entre os participantes e, também, gerenciam a publicação de conteúdos e as atividades na plataforma virtual.

Com relação à avaliação nesta modalidade de ensino, esta se dá tanto como instrumento de mensuração do desenvolvimento do aluno, quanto como um mecanismo de garantia de qualidade, ou ainda como um feedback dos processos de ensino e de aprendizagem. Neste contexto, é necessário um novo paradigma de avaliação formativa seguindo as características apresentadas.

Para Perrenoud (1999, p. 27), este tipo de avaliação pode ser compreendida como:

[...] toda prática de avaliação contínua que pretenda melhorar as aprendizagens em curso, contribuindo para o acompanhamento e orientação dos alunos durante todo o seu processo de formação. É formativa toda a avaliação que ajuda o aluno a aprender e a se desenvolver, que participa da regulação das aprendizagens e do desenvolvimento no sentido de um projeto educativo.

Vale destacar que as ações em EaD são norteadas por alguns princípios, podendo, segundo Leite (1998, p. 38), ser citados:

Flexibilidade, permitindo mudanças durante o processo, não só para os professores, mas também para os alunos; Contextualização, satisfazendo com rapidez demandas e necessidades educativas ditadas por situações socioeconômicas específicas de regiões ou localidades; Diversificação, gerando atividades e materiais que permitam diversas formas de aprendizagem; Abertura, permitindo que o aluno administre seu tempo e espaço de forma autônoma.

Existe, portanto, a necessidade de identificar a aprendizagem específica de cada estudante e o processo avaliativo que possui um caráter contínuo, permitindo evidenciar os ganhos de aprendizagem dos alunos em determinados contextos. A objetividade de um processo avaliativo deve se refletir na clara definição sobre que tipos de competências, habilidades e atitudes estão sendo avaliadas e o que é esperado de cada estudante (SILVA et al., 2015).

Luckesi (1995) reflete que o ato de avaliar não se encerra na configuração (atribuição) de uma unidade de valor ou qualidade ao objeto em questão. Para o autor, avaliar exige também uma tomada de posição, seja favorável ou desfavorável ao objeto de avaliação, com uma consequente decisão de ação. Afinal a avaliação em si deve direcionar (mover) o processo educativo em uma trilha dinâmica, divergindo portando da verificação, que promove somente o "congelamento". Por essas razões, para se desenvolver um bom processo avaliativo, necessariamente tem-se a verificação somente como um ponto de partida, para uma posterior tomada de atitudes no sentido de se promover alguma mudança na situação verificada. Seguidas estas etapas, pode-se dizer que há avaliação do aprendizado.

Diante disto, objetivou-se analisar as atividades solicitadas em um curso de licenciatura em Ciências Biológicas a distância, quanto aos produtos pedagógicos solicitados nas atividades, tipos de comunicação e de interação e categoria desse produto. Esta análise se faz necessária tanto para o processo de acompanhamento das avaliações do curso, averiguando se há diversidade nas atividades e se as mesmas contemplam os vários aspectos e ferramentas que são fundamentais para a prática docente, quanto para a aproximação dos alunos com a tecnologia. 


\section{METODOLOGIA}

Trata-se de pesquisa do tipo descritiva, com abordagem qualitativa, das atividades solicitadas para os alunos ingressantes no ano de 2012 e egressos no ano de 2016, sendo analisadas 171 atividades avaliativas postadas no Ambiente Virtual de Aprendizagem - AVA Moodle ${ }^{\circledR}$ versão 2.7, distribuídas ao longo das 38 disciplinas, descritas no Quadro 1.

Quadro 1 - Disciplinas constantes da matriz curricular do curso de Ciências Biológicas a distância UECE/UAB

\begin{tabular}{|c|l|}
\hline Semestre & \multicolumn{1}{|c|}{ Disciplinas } \\
\hline 2012.2 & $\begin{array}{l}\text { Introdução à Educação a Distância; Biologia Celular; Física para Ciências Biológicas; Química Geral e } \\
\text { Orgânica; Técnicas de Transmissão do Conhecimento Biológico. }\end{array}$ \\
\hline 2013.1 & $\begin{array}{l}\text { Psicologia do Desenvolvimento; Biofísica; Bioquímica; Matemática para Ciências Biológicas; } \\
\text { Fundamentos de Filosofia das Ciências. }\end{array}$ \\
\hline 2013.2 & $\begin{array}{l}\text { Bioestatística; Fundamentos de Geociências; Histologia e Embriologia Animal; Morfologia e } \\
\text { Taxonomia de Criptógamas; Psicologia da Aprendizagem. }\end{array}$ \\
\hline 2014.1 & $\begin{array}{l}\text { Biologia Molecular; Estrutura da Educação; Genética, Língua Brasileira de Sinais - LIBRAS, } \\
\text { Morfologia e Taxionomia de Espermatófitas. }\end{array}$ \\
\hline 2014.2 & $\begin{array}{l}\text { Didática Geral; Estágio Supervisionado no Ensino Fundamental; Microbiologia; Zoologia dos } \\
\text { Cordados. }\end{array}$ \\
\hline 2015.1 & $\begin{array}{l}\text { Ecologia, Estágio Supervisionado no Ensino Médio I; Fisiologia Humana Comparada; Fisiologia } \\
\text { Vegetal; Metodologia da Pesquisa Educacional. }\end{array}$ \\
\hline 2015.2 & $\begin{array}{l}\text { Anatomia e Fisiologia Humana; Biologia Evolutiva; Biotecnologia; Estágio Supervisionado no Ensino } \\
\text { Médio II; Projeto de Trabalho de Conclusão de Curso. }\end{array}$ \\
\hline & $\begin{array}{l}\text { Sistemática Vegetal; Estágio Supervisionado no Ensino Médio III; Parasitologia; Trabalho de } \\
\text { Conclusão de Curso. }\end{array}$ \\
\hline
\end{tabular}

As atividades foram classificadas considerando quatro critérios: produto solicitado na atividade (postado no AVA), tipo de comunicação, tipo de interação e categoria do produto. Para os três últimos critérios foi adotada a classificação proposta por Rios (2013), conforme evidenciado no Quadro 2.

Quadro 2 - Critérios de Classificação das Atividades segundo Rios (2013)

\begin{tabular}{|c|c|c|}
\hline Critério Analisado & Tipos Observados & Descrição \\
\hline \multirow{2}{*}{ Tipo de Comunicação } & Síncrona & $\begin{array}{l}\text { Comunicação em que os participantes interagem } \\
\text { simultaneamente, ou seja, em tempo real. }\end{array}$ \\
\hline & Assíncrona & $\begin{array}{l}\text { Comunicação que ocorre em tempos diversos, ou seja, quando } \\
\text { os participantes não precisam estar simultaneamente online. }\end{array}$ \\
\hline \multirow{3}{*}{ Tipo de Interação } & Individual & $\begin{array}{l}\text { Quando os participantes constroem e enviam seus produtos } \\
\text { sozinhos, ou seja, sem que haja interação com os demais } \\
\text { participantes. }\end{array}$ \\
\hline & Colaborativa & $\begin{array}{l}\text { Quando há a construção de um produto com o envolvimento } \\
\text { dos participantes de forma participativa, permitindo que } \\
\text { estes trabalhem juntos. }\end{array}$ \\
\hline & Em grupo & $\begin{array}{l}\text { Quando há a construção de um produto em equipe, ou seja, } \\
\text { com os participantes trabalhando juntos. }\end{array}$ \\
\hline \multirow{3}{*}{ Categoria do Produto } & Teórico & $\begin{array}{l}\text { Quando se refere a um produto educacional que tem como } \\
\text { base uma produção puramente teórica, ou seja, exigindo do } \\
\text { aluno a apropriação e o uso de conceitos. }\end{array}$ \\
\hline & Prático & Quando se refere à entrega de uma mídia digital. \\
\hline & Teórico-prático & $\begin{array}{l}\text { Quando se refere à entrega de um produto que se caracteriza } \\
\text { como um planejamento de atividade ou relato de uma } \\
\text { atividade já executada. }\end{array}$ \\
\hline
\end{tabular}

Por fim, a análise dos dados obtidos ocorreu mediante descrição e interpretação dos resultados, sendo os mesmos confrontados a luz da literatura atual. 


\section{RESULTADOS E DISCUSSÃO}

As atividades geraram 23 tipos de produtos, conforme Tabela 1, que contempla também a frequência (absoluta e relativa) em que as atividades foram propostas, seus respectivos tipos de comunicação, interação e categorias dos produtos.

Tabela 1 - Produtos pedagógicos solicitados pelo curso de Ciências Biológicas a distância - UECE/UAB

\begin{tabular}{|c|c|c|c|c|c|}
\hline $\begin{array}{l}\text { Produto Solicitado nas } \\
\text { Atividades }\end{array}$ & $\begin{array}{l}\text { Frequência } \\
\text { Absoluta }\end{array}$ & $\begin{array}{l}\text { Frequência } \\
\text { Relativa }\end{array}$ & $\begin{array}{c}\text { Tipo de } \\
\text { Comunicação }\end{array}$ & $\begin{array}{l}\text { Tipo de } \\
\text { Interação }\end{array}$ & $\begin{array}{l}\text { Categoria do } \\
\text { Produto }\end{array}$ \\
\hline Apresentação em Slides & 08 & $4,68 \%$ & Assíncrona & Individual & Teórico \\
\hline $\begin{array}{l}\text { Apresentação em Slides com } \\
\text { Áudio }\end{array}$ & 05 & $2,92 \%$ & Assíncrona & Individual & Teórico \\
\hline Cartilha Educativa & 03 & $1,75 \%$ & Assíncrona & Individual & Prático \\
\hline Diário Reflexivo & 02 & $1,17 \%$ & Assíncrona & Individual & Teórico-prático \\
\hline Elaboração de Atlas & 04 & $2,34 \%$ & Assíncrona & Individual & Teórico \\
\hline Exsicata & 01 & $0,58 \%$ & Assíncrona & Individual & Prático \\
\hline E-book & 03 & $1,75 \%$ & Assíncrona & Individual & Prático \\
\hline Mapa Conceitual & 10 & $5,85 \%$ & Assíncrona & Individual & Teórico \\
\hline Paródia Educacional & 02 & $1,17 \%$ & Assíncrona & Individual & Teórico \\
\hline Participação em Chat & 08 & $4,68 \%$ & Síncrona & Individual & Teórico \\
\hline $\begin{array}{l}\text { Participação em Fórum de } \\
\text { Discussão }\end{array}$ & 12 & $7,02 \%$ & Assíncrona & Individual & Teórico \\
\hline Participação em Quiz & 02 & $1,17 \%$ & Assíncrona & Individual & Teórico \\
\hline $\begin{array}{l}\text { Participação em Seminário } \\
\text { Online }\end{array}$ & 08 & $4,68 \%$ & Assíncrona & Em Grupo & Teórico \\
\hline Plano de Aula & 15 & $8,77 \%$ & Assíncrona & Individual & Teórico-prático \\
\hline Podcast Educacional & 03 & $1,75 \%$ & Assíncrona & Individual & Teórico \\
\hline Postagem em Blog Educacional & 13 & $7,60 \%$ & Assíncrona & Individual & Teórico \\
\hline Protocolo de Modelo Didático & 01 & $0,58 \%$ & Assíncrona & Individual & Teórico-prático \\
\hline Relatório de Aula Prática & 09 & $5,26 \%$ & Assíncrona & Individual & Teórico-prático \\
\hline Relatório de Visita à Escola & 01 & $0,58 \%$ & Assíncrona & Individual & Teórico-prático \\
\hline Resenha Crítica & 01 & $0,58 \%$ & Assíncrona & Individual & Teórico \\
\hline Texto Individual & 45 & $26,32 \%$ & Assíncrona & Individual & Teórico \\
\hline Texto Colaborativo - Wiki & 11 & $6,43 \%$ & Assíncrona & Colaborativa & Teórico \\
\hline Vídeo Educacional & 04 & $2,34 \%$ & Assíncrona & Individual & Prático \\
\hline
\end{tabular}

Pode-se inferir que, ao longo do período em que foi desenvolvida a análise, houve diversidade de atividades propostas, conferindo vantagem ao processo de ensino-aprendizagem do aluno, haja vista que $o$ uso de diversos tipos de ferramentas possibilita contemplar necessidades diferenciadas, respeitar as particularidades de organização de tempo e, mesmo que estejam distantes fisicamente, certas atividades, em especial às de natureza "Colaborativa" quanto ao tipo de interação, podem contribuir com a sensação de proximidade entre todos os envolvidos, um vez que são favorecidas as interações e é potencializada a comunicação.

Entretanto, segundo Depresbiteris e Tavares (2017), diversificar os instrumentos de avaliação não é o suficiente, sendo fundamental evitar a sua adoção de maneira "aleatória". Para as autoras supracitadas, a avaliação tem componentes teóricos e práticos e possui caráter metódico e pedagógico que configuram suas ações como intencionais e voltadas para o que se desejou alcançar. Nesse sentido, diversificar é romper a predisposição do avaliador em atuar sempre da mesma maneira.

Em contraponto, Vito e Szezerbatz (2017) destacam a importância da diversificação dos instrumentos avaliativos no ensino superior, bem como a elaboração das estratégias por parte dos professores com objetivos de proporcionar melhor qualidade na formação acadêmica e melhor desempenho dos alunos, pois são vários alunos e cada um tem suas particularidades no processo de aprendizagem.

Mesmo com a grande diversidade de atividades, ficou evidente a solicitação de "textos individuais", representando 26,32\% (45) do total de atividades. Embora este tipo de atividade não favoreça o trabalho colaborativo, é importante na vida acadêmica do estudante, uma vez que, segundo 
Paixão e Vidal (2015), para se construir textos de qualidade, sejam eles um artigo, resumo, resenha ou texto dissertativo-argumentativo, o aluno precisa fazer uma análise aprofundada dos textos técnicocientíficos lidos, bem como julgá-los coerentes. Sendo essas etapas necessárias para uma compreensão textual e significativa na construção do texto. Uma atividade relativa à produção, seleção e organização de textos exige do aluno a organização de ideias.

Rocha e Silva (2017) destacam que para a produção textual, a leitura, a escrita e a fala são fatores imprescindíveis, pois são condutores de ideias e devem ter valores iguais no processo de ensinoaprendizagem.

Moran (2018) aponta a necessidade da produção criativa por parte dos alunos e que sejam socialmente relevantes, de forma que seja dado o feedback e seja percebido a sua evolução, tanto individualmente quanto coletivamente. E, neste contexto, permite ao professor o momento de auto avaliação, que reflita sobre o alcance ou não dos seus objetivos e o porquê de não obter êxito, sendo uma avaliação formativa para o docente.

Na tabela 2 pode-se observar as frequências absoluta e relativa dos critérios para a classificação das atividades (Tipo de Comunicação, Tipo de Interação e Categoria do Produto).

Tabela 2 - Critérios Adotados para a Classificação das Atividades elaboradas durante o curso de Ciências Biológicas a distância - UECE/UAB

\begin{tabular}{|l|l|c|c|}
\multicolumn{2}{|c|}{ Critério Analisado } & \multicolumn{1}{c|}{$\begin{array}{c}\text { Frequência } \\
\text { Absoluta }\end{array}$} & Frequência Relativa \\
\hline \multirow{2}{*}{ Tipo de Comunicação } & Síncrona & 10 & $5,85 \%$ \\
\cline { 2 - 4 } & Assíncrona & 161 & $94,15 \%$ \\
\hline \multirow{3}{*}{ Tipo de Interação } & Individual & 130 & $76,03 \%$ \\
\cline { 2 - 4 } & Colaborativa & 09 & $5,26 \%$ \\
\cline { 2 - 4 } & Em grupo & 32 & $18,71 \%$ \\
\hline \multirow{3}{*}{ Categoria do Produto } & Teórico & 137 & $80,12 \%$ \\
\cline { 2 - 4 } & Prático & 06 & $3,51 \%$ \\
\cline { 2 - 4 } & Teórico-prático & 28 & $16,37 \%$ \\
\hline
\end{tabular}

Em relação ao tipo de comunicação, percebe-se maior frequência de atividades “Assíncrona”, 94,15\% (161), as quais apresentam como vantagens, o fato de os usuários podem construir seus produtos, ou mesmo interagir no seu próprio tempo, ou seja, no momento que lhes convier ser mais adequado.

Lima e Giordan (2017, p. 85) destacam que neste tipo de comunicação, “os interlocutores não compõem simultaneamente o contexto comunicativo. Em decorrência disso, eles são incapazes de intercalar turnos de falas ou reelaborar os enunciados em um contexto temporal ininterrupto".

Vale destacar que a comunicação assíncrona tem características próprias como a não simultaneidade, ou seja, pode ocorrer em momentos distintos entre os emissores e os receptores, respeitando as particularidades dos envolvidos.

Com relação ao tipo de interação, foi percebido o predomínio de atividades de caráter "Individual", ocorrendo em 76,03\% (130) dos casos. Embora no contexto educacional seja favorecido o trabalho individual como a principal forma de interação focada na relação aluno-professor, o trabalho, tanto em grupo como o colaborativo, é frequentemente apontado como estratégia de ensino que favorece a socialização dos alunos, colocando-os em situações nas quais precisam aprender a ouvir e respeitar a opinião dos colegas, a negociar e/ou renunciar às próprias ideias, ou ainda a colocar os objetivos pessoais em segundo plano (GALIAZZI; GONÇALVES, 2004). É também na discussão com seus pares que surgem o desenvolvimento lógico e a necessidade de se expressar coerentemente.

As metodologias de aprendizagem colaborativas podem reduzir o sentimento de solidão dos cursos em EaD, segundo Marriott (2008), quando um grupo de estudantes colabora e interage em conjunto, surge um sentimento de presença, que incentiva a aprendizagem. Desta forma, a aprendizagem colaborativa leva os alunos a um maior nível de engajamento, elevando a sua capacidade de resolver problemas, oferecendo diversas vantagens cognitivas. 
Neste contexto, as trocas de experiências incentivam e provocam o interesse e o pensamento crítico, possibilitando aos participantes alcançarem melhores resultados do que quando estudam individualmente. Corroborando com esta ideia, Ponte $(2017$, p. 21) afirma que "deve ter-se em atenção que a realização de discussões coletivas numa turma habituada a trabalhar num registo tradicional requer uma aprendizagem por parte dos alunos".

Portanto, propor aos alunos que estejam simultaneamente engajados na mesma tarefa, dando a eles um objetivo comum, cria-se a necessidade de comunicação, compartilhamento, coordenação e negociação do significado da atividade.

Sendo assim, Brito (2010, p. 86), afirma que

[...] processos colaborativos iniciam com a articulação de significado pessoal, levando outros membros do grupo a darem explicações, usando esse entendimento. Se aceito, os significados oferecidos podem tornar-se parte do sentido comum. No entanto, os membros da equipe podem divergir na sua interpretação e resolver a situação a partir de perspectivas diferentes. Em um sentido amplo, mediante um processo de colaboração, os estudantes têm oportunidades não só para descobrir e trabalhar juntos em um ambiente virtual, mas também para construção de interações sociais e estabelecer redes de colaboração humana para o resto de seus estudos.

Analisando as atividades quanto ao critério "Categoria do Produto", prevaleceu a proposição de atividades com o caráter "Teórico", representando 80,12\% (137) dos casos.

As produções Teóricas têm sua grande importância na construção do conhecimento, pois exigem que os alunos se apropriem de conhecimentos provenientes de diferentes fontes e os coloquem em prática, através da construção de atividades dos mais diversos tipos, sejam elas síncronas ou assíncronas, individuais, colaborativas ou em grupo.

Já as atividades "Teórico-práticas”, também apresentam significativo papel, pois no contexto do curso proporcionam ao aluno um exercício de planejar atividades para seu exercício futuro na profissão docente (no caso da entrega de Planos de Aula), ou ainda contribuem com a consolidação do conhecimento trabalhado por meio de algumas vivências. Por exemplo, quando é solicitada a entrega de um Relatório referente a uma Atividade Prática de Laboratório, ou a produção do Protocolo de construção e uso de algum modelo didático.

Sobre este assunto, Oliveira (2008, p. 4) afirma que

Quando instigados a pesquisar e a propor hipóteses para a solução de problemas, ou a pensar e fornecer explicações para os fenômenos observados nos experimentos, os alunos são estimulados a tomar decisões e expressar suas ideias para outras pessoas. Tais eventos, oportunizados pelas atividades experimentais, são extremamente importantes para formação social dos estudantes e fornecem-lhes uma base para enfrentar novas situações nas quais necessitem tomar iniciativas [...].

Já as atividades "Práticas", no contexto do referido estudo, destacam-se como recursos de dinamização do processo de ensino e aprendizado, atuam na facilitação da compreensão do conteúdo e na construção do conhecimento. Percebe-se que quando bem explorados em espaços educacionais, a produção de mídias (vídeos educacionais, $e$-books e cartilhas virtuais) podem colaborar significativamente com a melhoria no nível de aprendizado dos alunos.

Braga (2013, p. 77) destaca que "para introduzir a tecnologia digital em práticas de ensino, o professor precisa saber que tais recursos existem, definir quais ele precisa e onde e como ele procurá-los".

Segundo Schneider e Ribeiro (2013), tal metodologia contribui ao tornar o aluno sujeito produtor do seu próprio conhecimento, possibilitando a pesquisa, permitindo a experiência na produção de um material colaborativo, otimizando o desenvolvimento do pensamento crítico, promovendo a expressão e comunicação, favorecendo uma visão interdisciplinar e integrando diferentes capacidades. 


\section{CONSIDERAÇÕES FINAIS}

Dentre as atividades analisadas e classificadas quanto ao produto postado no AVA tiveram o texto individual como o mais solicitado; quanto ao tipo de comunicação, destacaram as ferramentas assíncronas, com interação individual e, quanto à categoria do produto realce para as atividades teóricas.

Com os resultados, pode-se inferir que os princípios da modalidade a distância são contemplados, quando se leva em conta a autonomia que os alunos devem ter para realizarem as suas atividades. Portanto, promover esta autonomia, no aluno, durante a sua formação de professor permite que este reflita acerca das diversas dimensões que a profissão contempla e o prepare criticamente para enfrentar a lida em sala de aula, mas com embasamento teórico, argumentativo e prático.

Utilizando-se dos diversos tipos de ferramentas, é possível criar nos alunos um sentimento de acolhimento. Tendo em vista serem contempladas suas necessidades, respeito as suas particularidades de organização de tempo, além de, mesmo que distantes fisicamente, transmitirem a sensação de proximidade entre todos os envolvidos.

Por fim, considera-se que é fundamental o bom planejamento, para a criação e inserção de atividades diversificadas, que estimulem a construção do conhecimento, onde os sujeitos possam contextualizar questões locais e globais do seu universo cultural e expressar-se contribuindo com o coletivo.

\section{REFERÊNCIAS}

[1] ARAUJO JÚNIOR, C. F. de; MARQUESI, S. C. Atividades em ambientes virtuais de aprendizagem: parâmetros de qualidade. In.: FORMIGA, M.; LITTO, F. M. Educação a distância: o estado da arte. São Paulo: Person Education, 2012.

[2] BERTOLIN, J. C. G.; MARCHI, A. C. B. Instrumentos para avaliar disciplinas da modalidade semipresencial: uma proposta baseada em sistemas de indicadores. Avaliação, v. 15, p. 131-146, 2012.

[3] BRAGA, D. Ambientes digitais: reflexões teóricas e práticas. São Paulo: Cortez, 2013.

[4] BRITO, J.A. Engajamento em atividades assíncronas na modalidade de ensino a distância: requisitos de interfaces colaborativas. Diss. Dissertação de mestrado em computação. Universidade Federal de Pernambuco (UFPE). Cin. Ciência da Computação (UFPE), 2010.

[5] DEPRESBITERIS, L.; TAVARES, M. R. Diversificar é preciso...: instrumentos e técnicas de avaliação de aprendizagem. Senac, 2017.

[6] GALIAZZI, M. C.; GONÇALVES, F. P. A natureza pedagógica da experimentação: uma pesquisa na licenciatura em Química. Química Nova, v. 27, n. 02, p.326-331, 2004.

[7] LEITE, L. S.; VIEIRA, M. L. S.; SAMPAIO, M. N. Atividades não presenciais: preparando o aluno para a autonomia In Tecnologia Educacional. Rio de Janeiro, ABT. Ano XXVI. n. 141, p. 36-40, 1997.

[8] LIMA, G. S.; GIORDAN, M. Características do discurso de divulgação científica: implicações da dialogia em uma interação assíncrona. Investigações em Ensino de Ciências, v. 22, n. 2, p. 83-95, 2017.

[9] LUCKESI, C. C. A avaliação da aprendizagem escolar. São Paulo: Cortez, 1995.

[10] MARRIOTT, R. Collaborative Learning: Key Issues. International Journal Co Learn, Open Learn Project - The Open University UK. November, n. 1, v. 1, 2008

[11] MORAN, J. M. Tecnologias digitais para uma aprendizagem ativa e inovadora. Disponível em: www2.eca.usp.br/moran Acesso em: 08 jun. 2020.

[12] OLIVEIRA, J. R. S. Contribuições e abordagens das atividades experimentais no ensino de ciências: reunindo elementos para a prática docente/Contributions and approaches of the experimental activities in the science teaching: Gathering elements for the educational practice. Acta Scientiae, v. 12, n. 1, p. 139-153, 2010.

[13] PAIXÃO, G. C.; VIDAL, E. M (Org.). Ferramentas tecnopedagógicas em EaD: orientações sobre processos de avaliação formativa. Fortaleza: Universidade Estadual do Ceará, 2015.

[14] PASSOS, M. L. S. Feedback como Parte Integrante da Avaliação Formativa em um Curso de Pós-graduação a Distância: Concepções da Equipe Multidisciplinar. Rev. Bras. Aprend. Aberta. v. 1, p. e351, 2020.

[15] PERRENOUD, P. Avaliação: da excelência à regulação das aprendizagens entre duas lógicas. Porto Alegre: Artes Médicas, 1999.

[16] PONTE, J. P. D. Discussões coletivas no ensino-aprendizagem da Matemática. In: INVESTIGAÇÃO, G.-G. D. T. D. (Ed.). A Prática dos professores: Planificação e discussão coletiva na sala de aula. Lisboa: APM - Associação de Professores de Matemática, 2017. 
[17] RIOS, M. F. S. Representação Social da Avaliação da Aprendizagem Virtual de Tutores: estudo em um Curso de Pedagogia, a distância no Nordeste brasileiro. 161 f. Dissertação (Mestrado em Desenvolvimento Humano) Universidade de Taubaté, Taubaté, SP, 2013.

[18] ROCHA, M. S.; SILVA, M. M. P. A Linguística Textual e a Construção do Texto: um estudo sobre os fatores de textualidade. Revista Digital dos Programas de Pós-Graduação do Departamento de Letras e Artes da UEFS. Feira de Santana, BA: v.18, n.2, p.26-44, 2017.

[19] SCHNEIDER, C. E; RIBEIRO, L. O. M. (2013). YouTube: parâmetros de legibilidade da produção de vídeos para a educação a distância. In: XIX Congresso Internacional ABED de Educação a Distância, 2013, Salvador, Bahia. Congresso Internacional ABED de Educação a Distância. São Paulo, SP: Associação Brasileira de Educação a Distância ABED, 2013. v. 1, p. 461-470.

[20] SILVA, T. E. V., RIBEIRO, G. O., SILVEIRA, I. F. E VASCONCELOS, F. H. L. Avaliação em EAD: teoria e prática. Recife. Imprima Soluções Gráficas. 2015. 1 ed., v. 500, p. 198, 2015.

[21] VITO, D. Z.; SZEZERBATZ, R. P. A avaliação no ensino superior: a importância da diversificação dos instrumentos no processo avaliativo. Revista da Educação, Umuarama, v. 17, n. 2, p. 221-236, jul./dez. 2017. 


\section{Capítulo 6}

\section{Artes visuais e educação: A formação de alunos de Arquitetura e Design}

\section{Erika Cabral Guimarães}

\section{Claudia Santos Martiniano}

\section{Isabel Dillmann Nunes}

Resumo: Este artigo tem como objetivo refletir sobre o debate e a importância do aprofundamento do conteúdo das artes visuais no ensino fundamental e médio brasileiro e sua influência na formação dos alunos de Arquitetura e Design. Trata-se de ensaio teórico estruturado a partir da argumentação teórica sobre a temática e da experiência vivenciada pela autora como professora de artes. Portanto, apresenta como eixo de análise as artes visuais e sua importância na educação; a relação entre arte e o ensino de Arquitetura e Design; o ensino da arte-educação - uma vivência no ensino fundamental e médio e a experiência com a formação de arquitetos e designers. Concluise que, o ensino das Artes nos anos fundamentais deve aprofundar a metodologia que estimula o ensino baseado em projetos, que engloba aspectos como a transdisciplinaridade, a criatividade, o trabalho em grupo, fundamental para todos os alunos e em particular para os futuros arquitetos e designers.

Palavras-chave: Artes visuais. Educação. Ensino fundamental e médio. Arquitetura. Design. 


\section{INTRODUÇÃO}

Apesar do progresso tecnológico das últimas décadas, no Brasil e no mundo e seu impacto na sociedade em geral, pouco tem sido viabilizado para mudar uma educação que ficou presa à paradigmas do início do século XIX e XX. Os alunos e alunas atuais têm acesso a tecnologias que não estavam disponíveis anteriormente e se desenvolvem com uma velocidade espantosa, surpreendo professores e gestores, que sentem dificuldade em acompanhar as mudanças. Além da falta de preparo para entender a tecnologia, pouco tem sido feito para compreender o aluno do século XXI (PRADO, 2015).

Num sistema educacional como o do Brasil, onde a prova é a principal forma de se medir o aprendizado, ir à escola pode se tornar uma atividade estressante. Alunos e alunas dificilmente conseguem enxergar a aplicabilidade da maioria das disciplinas no mundo real e estudam apenas para "escapar" de um sistema que lhes aprisiona, física e mentalmente. Essa realidade tem impacto particularmente na população de baixa renda, marginalizada por um sistema econômico desigual que não permite as mesmas oportunidades educacionais para todos.

Em uma sociedade que muda aceleradamente, os alunos e alunas são obrigados a se adaptar às demandas educacionais que objetivam preencher o mercado de trabalho, também em constante mudança. Diversas profissões novas emergiram a partir do advento da tecnologia da informação, e continuam surgindo, na medida em que essa tecnologia se desenvolve. 0 trabalhador do século XXI deverá ser um profissional flexível que tenha condições rápidas de adaptação a novos processos e tecnologias de trabalho. 0 acesso à tecnologia, desde os níveis mais básicos da educação, é essencial nesse novo contexto (PRADO, 2015).

Apesar da importância das tecnologias da informação no ambiente educacional, para que ela funcione de forma eficaz é crucial que o professor conheça o potencial das tecnologias e as relacione com o processo de ensino-aprendizagem para melhor aproveitamento possível (LEITE, 2014).

Diante dessa realidade, novas propostas e metodologias pedagógicas têm surgido na área de educação. As mais modernas propõem uma verdadeira desconstrução das escolas, redefinindo tanto o espaço físico, quanto as metodologias de ensino de todas as disciplinas. Uma das novas metodologias é o "ensino híbrido", focando a personalização, alternando o uso da internet com metodologias tradicionais e estimulando, entre outras atividades, o trabalho em grupo (LORENZONI, 2016). Fala-se muito também no chamado "Design Thinking", uma metodologia emprestada da área de design, que enfatiza o uso de processos utilizados em projetos de design e arquitetura para integrar de forma transdisciplinar os diversos componentes curriculares (SZCZEPANSKA, 2017). Complementando essa metodologia, tem sido introduzido nas escolas o "maker movement", que estimula a construção de objetos, através de uma metodologia "mão na massa". Alunos e alunas, sob orientação de professores e envolvendo várias disciplinas, são estimulados a projetar e construir protótipos e defender suas soluções. Um elo comum nessas metodologias mencionadas é a criatividade e a arte (LORENZONI, 2017).

No Brasil, registra-se uma lacuna no ensino fundamental e médio, em relação ao ensino de artes e outras disciplinas criativas, como trabalhos manuais e design, comum em outros países (FONTOURA, 2002). A recente discussão sobre a reforma do ensino médio demonstra que não há consenso sobre a importância dessa disciplina na formação dos alunos. Desde 1996, a lei n 9.394/1996, tornou o ensino de artes obrigatório no ensino fundamental e médio. No entanto, o governo do presidente michel temer, propõe uma reforma onde a o ensino das artes, seja facultativo no ensino médio (BRASIL, 2016).

Acreditando que todo ser humano é criativo, percebemos que os bloqueios criativos têm, entre várias causas, como fonte, a forma como os alunos brasileiros são trabalhados na escola fundamental e ensino médio, já que a arte não é devidamente valorizada nessa etapa tão crucial da escolarização.

Não existe um consenso sobre uma definição única de arte. Ela reflete a cultura e período que está inserida. Mesmo o sentido de beleza pode ser questionado, pois uma mancha de café no papel pode ser apenas uma mancha de café para alguns. Para outros pode haver significado, o de uma expressão artística. Mas então, podemos questionar qual o verdadeiro sentido da arte para o ser humano e sua importância na educação? Em entrevista à revista carta maior, a acadêmica e arte-educadora Ana Mae Barbosa coloca que a arte é importante.

Para trabalhar construção e cognição. Na construção da Arte utilizamos todos os processos mentais envolvidos na cognição. Existem pesquisas que apontam que a Arte desenvolve a capacidade cognitiva da criança e do adolescente de maneira que ele possa ser melhor aluno em outras disciplinas. A música desenvolve diversos processos cognitivos, comparando, organizando, selecionando. Em Arte, opera-se com todos os processos da atividade de 
conhecer. Não só com os níveis racionais, mas com os afetivos e emocionais. As outras áreas também não afastam isso, mas a Arte salienta ou dá mais espaço. Para desenvolver a criatividade em ciência, a criança tem que ter certo QI racional. Para desenvolver através da Arte, a necessidade de QI é muito menor. Significa que ele procura outros caminhos cognitivos. Eu acho que, em primeiro lugar, a função da Arte na Educação é essa, desenvolver as diferentes inteligências. (BARBOSA apud YODA; CARVALHO, 2006, p. 1).

Na nossa opinião, a falta da disciplina de Artes Visuais, em particular, inibe a criatividade dos alunos, e impacta diretamente na qualidade do ensino da Arquitetura e do Design, duas áreas essencialmente criativas. Na chamada sociedade do conhecimento, onde a capacidade criativa projetual é fundamental no desenvolvimento de novos produtos e tecnologias, é necessária uma mudança de mentalidade e a introdução de novas metodologias educacionais. Obter um diploma universitário, no contexto atual, não é garantia nenhuma de se conseguir um emprego.

Na era da Internet, existem milhares de pessoas autodidatas com portfólios de alta qualidade e experiência de trabalho. As escolas se acomodaram num sistema que emergiu no século XIX e se manteve sem maiores mudanças. Como coloca Le Roux (2016) o modelo de educação brasileira é fordista, sendo os alunos tratados em função do ano de fabricação e os mesmos conteúdos são impostos na mesma ordem, sem distinção. Esse modelo limita a criatividade, produzindo um conhecimento mecanizado.

Existem experiências recentes que procuram reduzir esse problema através do uso da metodologia de design, que será abordada posteriormente; o Design Thinking e o Movimento Maker (REGINALDO, 2015).

\section{REFERENCIAL TEÓRICO}

A seguir, tem-se a explanação do referencial teórico da pesquisa, em que serão abordadas considerações acerca: das artes visuais e sua importância na educação; e, da relação entre arte e o ensino de design e arquitetura.

\subsection{ARTES VISUAIS E SUA IMPORTÂNCIA NA EDUCAÇÃO}

A origem da escola no Brasil está ligada, prioritariamente, a uma necessidade de formação de mão de obra, baseada nas profissões tradicionais. Apesar de, em determinados momentos, as disciplinas de Artes estarem presentes, gradativamente, a importância dessas foi reduzida (PEREIRA; SILVA, 2011).

Atualmente é mínima a carga horária de disciplinas criativas no currículo da escola fundamental e do ensino médio, limitando-se, principalmente, à Introdução à História da Arte e Literatura. A disciplina de Artes, não é valorizada pela escola, haja vista que ela não existe em todos os anos escolares. Uma maior valorização ocorreu por causa do Exame Nacional do Ensino Médio (ENEM) que enfatiza basicamente a literatura.

Os paradigmas educacionais contemporâneos estão sendo questionados, principalmente após o advento da tecnologia da informação. Podemos considerar que essa nova tecnologia corresponde a uma nova Revolução Industrial, impactando em todas as áreas do conhecimento. A velocidade do desenvolvimento da informática surpreendeu a educação, que não estava preparada para absorver e gerenciar a avalanche de conhecimento disponibilizado.

Inovações radicais, como o chip de computador e a Internet, viabilizaram o acesso nunca antes vivenciado às informações e tecnologias. Essas mudanças trazem a necessidade de novas formas de pensar e se organizar para todas as atividades profissionais. No caso das disciplinas que projetam, aumenta a demanda pela rápida geração de ideias e capacidade criativa para criar cada vez mais produtos de qualidade. Nesse contexto, a arte, estimulada desde as primeiras séries escolares, tem um papel fundamental na sociedade atual. Read (1982) ressalta que a arte está em toda parte para satisfazer nossos sentidos, mas raramente nos detemos para considerar.

O conceito de arte engloba uma variedade de atividades humanas, como o cinema, a escultura, a música, a fotografia, a dança e a pintura. Traçando uma visão panorâmica do mundo através da história e da nossa atualidade, desde os povos primitivos, em diferentes civilizações encontraremos fortemente sinais das artes, seja como forma de expressão ou utilidade, como pode ser constatado nas pinturas rupestres nas cavernas de Chauvet-Pont-d'Arc, na França (WALTER, 2014). 
A arte impacta de forma positiva em vários aspectos da vida humana, como tomadas decisão, aprendizagem visual, criatividade, e consciência cultural. A arte-educação ajuda a resolver problemas e a pensar criticamente a partir de tomadas de decisão e opções que terão futuras consequências nas várias esferas da vida humana. As crianças e jovens, ao serem expostos às atividades artísticas, são estimulados a explorar alternativas visuais e experimentar materiais diversos, o que faz emergirem novas ideias e soluções.

A manipulação de materiais diferentes em trabalhos manuais estimula habilidades visuais-espaciais, fundamentais no século XXI. Com o advento da tecnologia da informação, as crianças, desde a mais tenra idade, são bombardeadas por imagens, na mídia ou nos equipamentos de uso pessoal como os telefones celulares, ou nos livros. Dessa forma, absorvem literalmente milhares de imagens por dia, criando um repertório visual próprio (LYNCH, 2017).

Todas essas habilidades, extremamente valorizadas por governantes, líderes empresariais, acadêmicos, e pela sociedade em geral, serão essenciais para atuação eficaz dos futuros profissionais no mercado de trabalho e mais importante, na educação de pessoas conscientes e críticas (ROBERTSON, 2017).

Enfatizamos nesse ensaio as artes visuais. Elas estimulam a percepção visual das crianças, contribuindo para sua alfabetização e conhecimento de mundo. Interagem com o meio ambiente, auxiliando no conhecimento das outras matérias do currículo. Um trabalho que valoriza a cultura, estabelecendo relações de mudanças criativas e socialização, desenvolvendo um olhar mais sensível e crítico formando cidadãos e cidadãs. Souza (2010, p. 3), esclarece que "o ensino de Arte trata de relacionar sentimentos, trabalhar aspectos psicomotores e cognitivos, planejar e implementar projetos criativos e se engajar emocionalmente neles, num permanente processo reflexivo".

Além disso, ensinar arte permite a conscientização de diversos valores, desabrochar da criatividade humana e o desenvolvimento interior das pessoas. Preenche outros objetivos como aumentar o senso de responsabilidade, a capacidade de exercer julgamento e tomar decisões, além de ser tolerante. Na sociedade do conhecimento é fundamental ter pessoas criativas, que encaram desafios sem amarras, ao invés de serem apenas seguidores de manuais. Através da experiência artística conseguem gerar alternativas diferenciadas e obter soluções mais eficientes para as suas vidas e a sociedade.

\subsection{RELAÇÃO ENTRE ARTE E O ENSINO DE DESIGN E ARQUITETURA}

Transformações consideráveis têm ocorrido em anos recentes em relação a economia mundial, que passa por um processo de globalização e de valorização do conhecimento. Na "sociedade do conhecimento" há uma mudança de paradigma, onde a inovação tecnológica passa a ser um dos principais motores da economia. Para obter sucesso nesse contexto é necessário um sistema de inovação eficaz que permita a constante criação de novos processos e produtos. Para atingir esse fim, a criatividade, um bem intangível, é cada vez mais valorizada. Entre as áreas mais importantes num sistema de inovação, estão o Design e a Arquitetura. Todas elas têm no seu cerne a inovação e a criatividade, impactando substancialmente a economia. A importância de uma economia criativa, pode ser constatada pela recente implantação, no Brasil, da Escola Britânica de Artes Criativas. A escola, localizada em São Paulo, pretende preencher parte da lacuna educacional acima mencionada. Em matéria recente sobre a escola, Nunes (2016) coloca que:

Com a economia criativa em constante crescimento, é importante que lugares como este se propaguem a fim de ajudar os criativos a desenvolverem suas ideias e aptidões. Segundo o IBGE, a contribuição formal dos setores criativos ao PIB do Brasil em 2010 foi de R\$104,37 bilhões ou 2,84\% do PIB brasileiro. Os dados do Ministério do Trabalho apontam que hoje existem mais de 1 milhão de brasileiros empregados nos setores criativos, com um crescimento de mais de 90\% nos últimos 10 anos. (NUNES, 2016, p. 1).

0 termo economia criativa remete a diversas atividades econômicas que se baseiam, para gerar emprego e renda, no conhecimento, capital intelectual e principalmente na criatividade. Nessas atividades estão inseridas a Arquitetura e o Design, responsáveis pela criação de produtos. A economia criativa no mundo, no ano 2000, era estimada em mais de dois trilhões de dólares e sua tendência era crescer em $5 \%$ ao ano (UNDP, 2013).

Para o desenvolvimento da economia criativa, é fundamental que exista um sistema educacional eficaz, que permita o aproveitamento do capital humano existente em cada país. No caso da ciência e da tecnologia, é necessário que as disciplinas técnicas sejam estimuladas desde cedo. 
Países que se sobressaíram no teste do Programme for International Student Assessment (PISA), como a Finlândia e a Suécia, têm uma percepção diferenciada de como a educação pode desenvolver habilidades que preparam os estudantes para futuramente exercerem atividades criativas, como a Arquitetura e o Design. Ou seja, uma educação para ser útil na vida. Desde pequenos os alunos e alunas já têm boas noções práticas das habilidades que serão necessárias no seu cotidiano. Por exemplo, sabem a importância de ter um bom portfólio, calcular impostos, elaborar um contrato, etc. Os currículos nesses países expressam que a educação não deve ser massificada. Focam na autonomia e educação individual, dando importância ao trabalho transdisciplinar. Na Finlândia está sendo implantado um novo currículo que pretende aprofundar essa transdisciplinaridade, dando maior liberdade aos docentes para escolher como o conteúdo será abordado entre as diversas disciplinas. Ferramentas digitais também têm sido empregadas mais assiduamente em sala de aula.

Esse processo de digitalização não significa apenas colocar um computador em sala de aula, mas usar essas ferramentas tecnológicas para aumentar e melhorar o processo de aprendizado, por exemplo, usando jogos. Sobretudo, nós queremos que aprender seja divertido (ESTADO DE SÃO PAULO, 2016, p. 1).

Alunos e alunas são instigados a serem curiosos e ativos, participam de oficinas, aprendem a cozinhar, consertar e reaproveitar eletrodomésticos e outros produtos, estimulando a compreensão de conceitos de física, química e matemática, além de noções básicas de engenharia e tecnologia. Tudo isso feito de maneira prazerosa, sem exigências desnecessárias, pois acreditam que o lazer é uma parte fundamental da educação e do desenvolvimento do ser humano.

Parte da discussão atual nos países mais desenvolvidos sobre o ensino da Ciência, Tecnologia e Engenharia tem focado nas disciplinas mais evidentes das áreas de exatas, a saber a Matemática, a Física e a Química. Considera-se como o estado da arte o acrônimo STEM - Science, Technology, Engineering and Mathematics, que tem sido entendido como crucial para o desenvolvimento da inovação na chamada sociedade do conhecimento.

Apesar dos avanços no ensino das disciplinas que compõem o STEM, tem-se desconsiderado uma área fundamental, que poderia ser aglutinadora dessas várias disciplinas, o ensino das artes visuais. Alguns autores, como Watson e Watson (2013), argumentam sobre a necessidade do ensino das artes visuais, pois esse ensino não traz respostas prontas. Exige do aluno uma busca de soluções, através da prática e da geração e escolha de alternativas, portanto, sugerem o STEAM Science, Technology, Engineering, Arts and Mathematics. Há décadas, cientistas relevantes reconhecem a importância da relação entre ciência e arte e veem benefícios nessa conexão, como sugeriu Albert Einstein "I am enough of an artist to draw freely upon my imagination. After a certain high level of technical skill is achieved, science and art tend to coalesce in esthetics, plasticity, and form. The greatest scientists are artists as well" Albert Einstein" (JOHNSTONE, 2016).

Apesar da atual repercussão do Design Thinking, principalmente na área de administração (KOLKO, 2015; TURNALI, 2017) e mais recentemente na área educacional, essa metodologia ou processo de geração de ideias não é algo novo. 0 Design Thinking vem sendo usado desde a década de 1960 e tem se apropriado de técnicas e conhecimentos de diversas áreas. 0 termo engloba diversas abordagens e tem sido utilizado com um termo abrangente que "catches multi-disciplinary, human-centered projects that involve research and rapid ideation”. (SZCZEPANSKA, 2017, p. 1).

Na Finlândia, a Arte, em particular, atua como um diferencial, pois estimula a colaboração entre os alunos. 0 ambiente escolar é repleto de estímulos visuais. No currículo básico deste país a arte é tão valorizada que a carga horária será aumentada, para estimular ainda mais a criatividade e as habilidades de comunicação, principalmente entre os meninos com uma tendência para a área de exatas (PREVIDELLI, 2013).

\section{METODOLOGIA}

Do ponto de vista metodológico o presente trabalho se constitui num ensaio teórico que se caracteriza por sua natureza reflexiva e interpretativa. 0 ensaio teórico pode ser definido como "um estudo bem desenvolvido, formal, discursivo e concludente, consistindo numa exposição lógica e reflexiva, e em uma argumentação rigorosa, com alto nível de interpretação e julgamento pessoal." (SEVERINO, 1996, p. 120). 
O objeto de análise do presente ensaio é o ensino das artes visuais no ensino fundamental e médio brasileiro e sua influência na formação dos alunos de Arquitetura e Design. 0 processo de análise dá-se a partir da manifestação do objeto como fenômeno, qual seja a dificuldade de lidar com as questões mais simples do conteúdo das artes verificada nos alunos e alunas dos referidos cursos.

Considerando como Meneghetti (2011) que a força do ensaio está na capacidade reflexiva para se compreender a realidade, tornou-se necessário recorrer, além da revisão bibliográfica, ao recurso metodológico do relato de minha experiência como professora de artes em dois momentos distintos. Essas experiências foram úteis na problematização e argumentação prática da temática em debate, sendo possível a relação permanente entre sujeito e objeto, característica precípua do ensaio teórico. 0 procedimento técnico utilizado no presente documento foi a pesquisa bibliográfica.

Pressupomos que o conteúdo relacionado às Artes ou temas afins não recebe a devida importância no ensino fundamental e médio, implicando numa formação superficial dos alunos das áreas supracitadas. Argumentamos que o aprofundamento da disciplina de artes visuais, e em particular a aplicação das metodologias de projeto utilizadas na área de design, associadas às teorias educacionais que estimulam o aprendizado prático e a implantação de infraestrutura para a viabilização da construção de projetos, têm o potencial de minimizar os problemas atuais detectados. Mediante o exposto, esse artigo tem como objetivo refletir sobre o debate e a importância do aprofundamento do conteúdo das artes visuais no ensino fundamental e médio brasileiro na formação dos alunos de Arquitetura e Design.

\section{0 ENSINO DA ARTE-EDUCAÇÃO - UMA VIVÊNCIA NO ENSINO FUNDAMENTAL}

Nosso primeiro envolvimento com a educação ocorreu em escolas inglesas, em 1986 e 1988, e foi repetida 1991-1995 e em 2000-2001, onde houve oportunidade de se trabalhar como professora voluntária com crianças entre quatro a nove anos, em turmas com trinta alunos, em quatro escolas públicas na cidade de Birmingham, a segunda cidade mais populosa do Reino Unido. Nas aulas trabalhávamos assuntos variados, com grupos de seis crianças. Na maioria das atividades a arte se fazia presente, com música, teatro, dança e principalmente nas artes visuais, estimulando a criatividade e soluções de problemas do cotidiano.

Os profissionais estavam sempre participando de capacitações, e existia uma preocupação em mantê-los sempre atualizados. 0 ambiente da escola e as salas de aulas, decoradas com trabalhos dos alunos, propiciava uma atmosfera de estímulo para a aprendizagem, onde as crianças eram encorajadas a serem independentes.

As crianças eram estimuladas a registrar, diariamente, as atividades, através de textos e de desenhos, pinturas ou modelagem. 0 processo de "mão na massa" ativava e estimulava a criatividade, além de influenciar no comportamento, pois muitos trabalhos eram feitos de forma colaborativa, contribuindo para a socialização, algo fundamental na vida profissional do século XXI.

A oportunidade de ensinar arte educação, em uma escola particular e em uma escola pública e no município de Campina Grande-PB, apesar das diferenças de contexto, possibilitou estabelecer uma relação com a experiência vivenciada por nós no Reino Unido. Ambas as escolas brasileiras não possuíam um projeto arquitetônico favorável ao ambiente escolar, diferentemente das escolas inglesas, que haviam sido projetadas especialmente como um ambiente de aprendizado. Na literatura de arquitetura e de design, argumenta-se que o espaço físico e os equipamentos escolares, como o mobiliário têm um impacto direto na qualidade do ensino-aprendizado (BARRET; ZHANG, 2009). Registramos ainda deficiência em relação aos materiais didáticos, mas principalmente a fragilidade na formação dos professores, visto que era perceptível a dificuldade para a realização de um trabalho transdisciplinar.

Na década de 1990 e em 2002, conseguimos inserir a arte visual na escola municipal, como parte do conteúdo pedagógico, aplicando a experiência vivenciada no Reino Unido, através da interação entre os componentes curriculares. Entendemos que são realidades diferentes, com contextos educacionais específicos. Porém em determinados momentos conseguimos estabelecer uma correlação entre esses dois contextos e, aos poucos, pudemos verificar mudanças nos trabalhos. Durante o período mencionado, notou-se uma significativa melhora na concentração das crianças quando executavam as atividades, um aumento de interesse nos assuntos abordados, redução na agressividade de alguns alunos e alunas e, principalmente, naqueles da escola pública onde os problemas são exacerbados. Durante a nossa vivência nessas escolas, pudemos constatar que a arte educação, presente desde os primeiros anos escolares, contribuiu de uma forma bastante eficaz para a formação do aluno, corroborando os exemplos verificados nos textos e na nossa experiência nas escolas europeias. 


\section{ENTRE LACUNA E O LEGADO - A FORMAÇÃO DE ARQUITETOS E DESIGNERS}

Nossa experiência profissional, nos períodos iniciais, do ensino superior, revela que, em geral, alunos recém-chegados do ensino médio, com algumas exceções, possuem pouco conhecimento sobre artes. Assim como em outras profissões, muitos alunos que optam pela arquitetura, o fazem ou por imposição da família, que já tem algum profissional atuando na área, ou por influência do modismo ou de amigos ou ainda por serem ainda muito jovens e imaturos; poucas vezes tomam uma decisão consciente.

O desenho e a história da arte, entre outros, são conhecimentos básicos para um profissional da área de arquitetura e design, porém, existem problemas que dificultam o ensino na área de arquitetura e design. Entre os mais evidentes, estão o bloqueio criativo e a falta de domínio da linguagem do desenho. Pode-se observar que muitos alunos, por causa dessa deficiência, mostram-se muito resistentes em aprender essa linguagem, ferramenta de grande importância para o futuro arquiteto e designer.

Verifica-se que muitos estão num nível primário de desenho. Apesar de existirem outras variáveis, nossa opinião informal, é que o fato dos alunos, após o ensino Fundamental I, terem poucas oportunidades e estímulos de se expressar através da arte-educação e principalmente através do desenho, ao chegar à universidade apresentam uma representação gráfica superficial. Apesar disso, pode-se perceber que alguns alunos já trazem algum domínio da representação gráfica, que pressupomos serem habilidades natas que foram estimuladas em casa ou em alguma escola.

Acreditando ser o desenho uma linguagem que se pode aprender, procuramos estimular os alunos, por meio de atividades práticas em sala de aula e em campo. 0 objetivo inicial é que os alunos "aprendam a ver" e não simplesmente "olhar" o mundo. Ver, implica em observar, entender o que está sendo observado e registrar de forma compreensível seus detalhes. Esse conhecimento irá compor o vocabulário visual das alunas e dos alunos.

No mundo atual, onde a velocidade com que recebemos as informações impede que sejam digeridas de forma apropriada, os detalhes passam despercebidos. As imagens são consumidas e descartadas em segundos, numa verdadeira avalanche de informações superficiais. Para profissionais criativos, como designers e arquitetos, para os quais os detalhes são fundamentais, é necessário um reaprendizado para que possam extrair a essência do conteúdo visual. Nesse aspecto o desenho de observação é fundamental, pois obriga estudantes a parar e olhar com profundidade.

Outro aspecto importante é que estimula a reflexão sobre o objeto observado permitindo a sua contextualização. Além disso, o domínio da representação gráfica permite, de forma criativa, a exploração de conceitos durante as fases preliminares de projeto. Isso possibilita aos alunos e alunas e aos profissionais um feedback constante permitindo uma avaliação criteriosa das soluções embrionárias. A partir dessa análise são escolhidas as alternativas com maior potencial de desenvolvimento. Nas fases intermediárias o desenho é fundamental para a comunicação com clientes e outros profissionais, facilitando o andamento do projeto. Nas fases finais do projeto o conhecimento de desenho é fundamental, mesmo quando utilizando a renderização via computadores. Pacheco e Vizioli (2013, p. 1), reconhecem a importância da prática constante do desenho no processo projetual: "O desenho é exercício da percepção e deve ser constantemente trabalhado para que mantenha sua eficácia, de manter constante o aprendizado sobre a percepção do que nos cerca: com o desenho sempre trabalhado, o olhar é sempre trabalhado".

Nos cursos de arquitetura e design, os componentes curriculares que abordam técnicas construtivas, expõem as dificuldades dos alunos, que estão relacionadas à falta de conhecimento e domínio dos materiais e o uso de ferramentas, como estiletes, esquadros, tesouras, etc. Essas disciplinas geralmente são ministradas no início dos cursos, envolvem técnicas de construção agregando uma série de habilidades importantes para alunos e alunas, estimulando a destreza no uso das ferramentas, a precisão no trabalho com medidas, a introdução do uso de escalas variadas e a manipulação de materiais diversos. Porém, um dos aspectos mais importantes da disciplina, é o que tange à criatividade, pois funciona como um "esboço" da atividade projetual, onde se lançam desafios para se trabalhar com a forma. Como num projeto arquitetônico, baseia-se num tema determinado, exige-se dos estudantes a geração de ideias, análises, seleção de alternativas e desenvolvimento da alternativa selecionada. A partir dessa seleção é construído o modelo final do exercício. Entendemos que a transdisciplinaridade pode trazer benefícios significativos para a superação das dificuldades supracitadas, melhorando a relação ensino-aprendizagem.

Outro aspecto relevante em aulas práticas é que nos permite usar a música para torná-las mais agradáveis e estimulantes, e ajudar na concentração, pois o trabalho envolve atividade criativa. Essa prática se mostra bastante interessante, na medida em que pode ajudar os alunos a se sentirem mais à vontade e mais 
calmos em sala de aula, facilitando o desenvolvimento das atividades, embora possam surgir problemas em relação ao gosto musical de cada um, na medida em que cada um tem a sua percepção estética, nesse caso o gosto por determinado estilo musical.

Pode-se aproveitar este contexto, para mostrar a importância de respeitar as opções e diferenças de cada um, explicando que no futuro eles irão trabalhar com pessoas de personalidades diferentes, em ambientes diversificados. A profissão de arquiteto e designer, e o futuro de todas as outras, exige cada vez mais um trabalho compartilhado e colaborativo.

\section{CONSIDERAÇÕES FINAIS}

Apesar do progresso ocorrido em alguns países, no Brasil defendemos ser ainda necessário tornar a Arteeducação permanente nos ensinos Fundamental e Médio. No caso das áreas de arquitetura e de design, verifica-se que, do modo como vem sendo ofertado o ensino das artes nos anos fundamentais tem deixado lacunas importantes que são percebidas na dificuldade de alunos e alunas de arquitetura e design em lidar com o conteúdo de artes. Essa situação tende a agudizar-se caso seja levado adiante a proposta do atual governo de tornar optativo o componente curricular de Artes no ensino médio.

Para que haja um impacto eficaz nos alunos que chegam à universidade, ainda há um longo caminho a percorrer. O primeiro passo é conhecer bem características, potencial e limitações do aluno do século XXI, desde o ensino fundamental.

A revisão bibliográfica revelou que duas metodologias pedagógicas, o Design Thinking e o Movimento Maker são importantes para melhorar a educação criativa em nossas escolas. Essas duas metodologias estão relacionadas ao ensino das Artes, e em particular ao ensino das artes visuais, pois envolvem processos cognitivos mentais semelhantes. Projetar, e construir desenvolve processos de aprendizagem, pois exige dos alunos e alunas aprender a organizar, comparar e selecionar, permitindo um conhecimento aprofundado, mas ao mesmo tempo estimulando a exploração de soluções variadas, fundamentais para o crescimento sistêmico humano.

0 reconhecimento da necessidade de se ministrarem, no ensino fundamental e médio, disciplinas de forma integrada e utilizando projetos, para tornar a transdisciplinaridade eficaz, teve no STEM um importante aliado. A introdução das artes no STEM tem trazido benefícios, estimulando alunos e professores no processo de ensino aprendizado, pois a Arte tem demonstrado a capacidade de integrar as disciplinas, e aplicar seu conteúdo no cotidiano. Disciplinas com muito conteúdo teórico, onde os alunos não conseguem perceber uma aplicação prática para esse conhecimento, beneficiam-se, podendo se tornar prazerosas, aumentando o interesse dos discentes e seu aproveitamento escolar.

Apesar da atual repercussão do Design Thinking, principalmente na área de administração e mais recentemente na área educacional, essa metodologia ou processo de geração de ideias não é algo novo. Entendemos que essas metodologias devem ser utilizadas de forma integrada para que sejam eficazes. Isso irá demandar das coordenações acadêmicas um trabalho com o corpo docente e discente, estimulando a participação transdisciplinar. Isso não é tarefa fácil, requer dos docentes um trabalho constante de parceria, procurando entender como a compreensão do conteúdo das disciplinas pode ser facilitado, através da implementação dessas duas metodologias.

Nos componentes curriculares de desenho e maquetes, pode-se aplicar diversos conhecimentos da arteeducação, do Design Thinking e do Movimento Maker, como a experimentação com materiais diversos, técnicas de colagem, pintura, modelagem, esboço a mão livre, estudo de perspectiva, figura humana, conhecimento do trabalho de diversos artistas, etc. Isso contribui de forma positiva para as outras disciplinas, pois através da manipulação desses materiais e do uso dos conhecimentos adquiridos, além de estimular a colaboração entre os alunos, possibilita a aplicação prática em vários outros componentes curriculares. Por exemplo, a manipulação de materiais, como o papel, isopor, sabão, entre outros, nos exercícios de plástica, facilita a construção de maquetes nas disciplinas de projeto. 0 desenho à mão livre permite a geração de conceitos básicos de design arquitetônico, estimulando à criatividade nas disciplinas de projeto e afins.

Esse artigo apresentou uma reflexão da importância do ensino da arte para a educação e para algumas formaç̧ões, em especial a Arquitetura e o Design. As nossas experiências no ensino da arte na escola fundamental e no ensino superior, nos permite afirmar que a orientação que vem sendo posta pelo atual governo federal de tornar facultativo ao ensino médio o componente curricular de Artes nos parece um 
retrocesso que implicará no agravamento do problema da pouca familiaridade dos graduandos com a arte. Está aberto o debate.

\section{REFERÊNCIAS}

[1] BARBOSA, A. M. Entrevista. In: YODA, Carlos Gustavo; CARVALHO, Eduardo. Entrevista - Ana Mae Barbosa. [S.l.]: Carta Maior, 2006. Disponível em: <http://www. cartamaior.com.br/?/Editoria/Midia/ Entrevista-\%96-AnaMae-Barbosa/12/10517>. Acesso em: 10 mar. 2017.

[2] BARRET, P.; ZHANG Y. Optimal learning spaces: design implications for primary schools. [S.l.]: Salford Centre for Research and Innovation in the built and human environment (SCRI), 2009.

[3] BRASIL. Medida Provisória no 746, de 2016. Brasília: Senado Federal, 2016. Disponível em: <http://www25.senado.leg.br/web/atividade/materias/-/materia/126992>. Acesso em: 08 jan. 2017.

[4] DESIGN AND TECHNOLOGY ASOCIATION. We believe in design and technology. what do you believe in? Manifesto for design and technology education. Wellesbour ne: The Design and Technology Association, 2011. Disponível em: <http://blogs. osc-ib.com/wp-content/uploads/2011/02/DT-Manifesto.pdf>. Acesso em: 01 maio 2016.

[5] ESTADO DE SÃO PAULO. Exemplo na área de educação: Finlândia atualiza o currículo. [S.l.: s.n.], 2016. Disponível em: <https://educacao.uol.com.br/noticias/ agencia-estado/2016/03/30/exemplo-na-area-de-educacaofinlandia-atualiza-curriculo.htm>. Acesso em: 14 jan. 2017.

[6] FONTOURA, A. M. EdaDe: a educação de crianças e jovens através do Design. (Tese - Doutorado em Engenharia). Florianópolis: Universidade Federal de Santa Catarina, 2002.

[7] JOHnSTONE, G. The producer's story: why Einstein was like Picasso. [S.l.: s.n.], 2016. Disponível em: <http://www.pbs.org/wgbh/nova/einstein/producer.html>. Acesso em: 28 dez. 2016.

[8] KOLKO, J. Design thinking comes of age. Havard Business Review, set. 2015. Disponível em: <https://hbr.org/2015/09/Design-thinking-comes-of-age>. Acesso em: 09 jan. 2017.

[9] LE ROUX, M. O diploma morreu... viva o portfolio: esta e outras reflexões sobre o que nos prepara de fato para a vida. [s.l.: s.n.], 2016. Disponível em: <http://projeto draft.com/o-diploma-morreu-viva-o-portfolio-esta-eoutras-reflexoes-sobre-o-que-nos-prepara-de-fato-para-a-vida/>. Acesso em: 08 fev. 2017.

[10] LORENZONI, M. Aprendizagem maker: infográfico explica a tendência na educação do século 21. [S.l.: s.n.], 2017. Disponível em: <http://info.geekie.com.br/aprendi zagem-maker/>. Acesso em: 08 fev. 2017.

[11] Tendências na educação: é tudo novidade? [s.l.: s.n.], 2016. Disponível em: <http://info.geekie.com.br/tendencias-na-educacao-novidade/>. Acesso em: 08 fev. 2017.

[12] LYNCH, G. H. The importance of art in child development. [S.l.: s.n.], 2017. Disponível em: <http://www.pbs.org/parents/education/music-arts/the-importance-of-art-in-child-development/>. Acesso em: 11 jan. 2017.

[13] MENEGHETTI, F. K. O que é um ensaio-teórico? Rev. Adm. Contemp. Curitiba, v. 15, n. 2, p. 320-332, abr. 2011. Disponível em: <www.scielo.br/scielo.php?script=sci_arttext \&pid=S1415-65552011000200010\&lng=en\&nrm=iso >. Acesso em: 20 jan. 2017.

[14] NUNES, B. São Paulo ganha escola britânica focada em arte e economia criativa. [S.l.: s.n.], 2016. Disponível em: <www.hypeness.com.br/2016/05/sao-paulo-tera-escola-britanica-focada-em-arte-e-economiacriativa>. Acesso em: 03 maio 2016.

[15] PACHECO, P. R.; VIZIOLI, S. H. T. O desenho no processo projetivo: estudo das representações gráficas de projetos de Paulo Mendes da Rocha. Revista Urbanismo e Design, São Paulo, v. 2, 2013. Disponível em: <http://www.producao. usp.br/handle/BDPI/43977>. Acesso em: 10 jan. 2017.

[16] PEREIRA, C. C. S.; SILVA, M. K. Grafismo infantil: leitura e desenvolvimento. Caderno de Formação Educação Infantil: Princípios e Fundamentos, São Paulo, v. 3, 2011.

[17] PRADO, A. Entendo o aluno do século 21: e como ensinar a essa nova geração. [S.l.: s.n.], 2015. Disponível em: <www.geekie.com.br>. Acesso em: 10 jan. 2017.

[18] PREVIDELLI, A. 10 lições da Finlândia para a educação brasileira. [S.l.: s.n.], 2013. Disponível em: <http://exame.abril.com.br/brasil/10-coisas-que-a-finlandia-pode-ensinar-ao-brasil/>. Acesso em: 24 maio 2013.

[19] READ, H. A educação pela arte. São Paulo: Martins Fontes, 1982.

[20] REGINALDO T. Referenciais teóricos e metodológicos para a prática do design thinking na educação básica. (Dissertação). Florianópolis: Universidade Federal de Santa Catarina, 2015. 
[21] ROBERTSON, K. O. The Arts and Creative Problem Solving. [S.l.s.n.], 2017. Disponível em: <http://www.pbs.org/parents/education/music-arts/the-arts-and-creative-problem-solving/>. Acesso em: 11 jan. 2017.

[22] SEVERINO, A. J. Metodologia do trabalho científico. 20. ed. São Paulo: Cortez, 1996.

[23] SOUZA, J. Arte no ensino fundamental. SEMINÁRIO NACIONAL: CURRÍCULO EM MOVIMENTO PERSPECTIVAS ATUAIS, 1., 2010, Belo Horizonte. Anais... Belo Horizonte: [s.n.], 2010.

[24] SZCZEPANSKA, J. Design thinking, where it came from and the types of people who made it all happen. [S.l.: s.n.], 2017. Disponível em: <https://medium.com/@szcz panks/Design-thinking-where-it-came-from-and-the-type-of-peoplewho-made-it-all-happen-dc3a05411e53?ref=webDesignernews.com\#.>. Acesso em: 15 jan. 2017.

[25] TURNALI, K. Empathy, Design Thinking, And An Obsession With Customer-Centric Innovation. Forbes, jan. 2017. Disponível em: <http://www.forbes.com/sites/sap/ 2016/01/17/empathy-Design-thinking-and-an-obsessionwith-customer-centric-innovation/\#51a76fc74285>. Acesso em: 10 mar. 2017.

[26] UNDP. United Nations Development Programme. Creative Economy Report 2013 Special Edition: Widening Local Development Pathways. Paris: [s.n.], 2013.

[27] WALTER, C. World's Most Ambitious Re-Creation of Prehistoric Cave Art to Open. [S.l.]: National Geographic, 2014. Disponível em: <http://news.nationalgeographic .com/news/2014/12/141219-chauvet-paleolithic-cave-artpaintings-france-ancient-culture>. Acesso em: 10 fev. 2017.

[28] WATSON, A. D.; WATSON, G. H. Transitioning STEM to STEAM: reformation of engineering education. The Journal for Quality and Participation, p. 1-4, out. 2013. 


\section{Capítulo 7}

\section{Sala de Recursos Multifuncionais -SRM}

\section{Nilma de Paula Calado}

Resumo: Este capítulo visa apresentar a experiência da Escola Municipal José Alberto de Lima com a utilização de uma sala de recursos multifuncionais. A escola, orientada nos princípios da Educação Inclusiva, visa possibilitar a quebra do ciclo de exclusão, desafiar os preconceitos, dando oportunidade para as pessoas com deficiência para que elas construam o seu próprio futuro. 


\section{INTRODUÇÃO}

Sabemos que a Educação Inclusiva é uma abordagem que procura atender as necessidades de aprendizagem de todas as crianças, jovens e adultos, com foco naqueles alunos que enfrentam barreiras para a participação nos processos de aprendizagem escolar.

Existem diversas formas de exclusão escolar, dentre elas, destaca-se aquela que diz respeito aos alunos com necessidades educacionais especiais.

A declaração de Salamanca, 1994, afirma que todas as crianças têm necessidades e aprendizagens únicas, que têm o direito de ir à escola da sua comunidade, com acesso ao ensino regular, e que os sistemas educacionais devem implementar programas considerando a diversidade humana e desenvolvendo uma pedagogia centrada na criança.

\section{METODOLOGIA}

Nessa perspectiva, a Escola Municipal José Alberto de Lima orientada nos princípios da Educação Inclusiva possibilita quebrar o ciclo de exclusão, desafiar os preconceitos, dando oportunidade as pessoas com deficiência para que elas construam o seu próprio futuro.

As salas de recursos multifuncionais são ambientes dotados de equipamentos, mobiliários e materiais didáticos e pedagógicos para a oferta do atendimento educacional especializado que tem como objetivos: Prover condições de acesso, participação e aprendizagem no ensino regular aos alunos com deficiência, transtornos globais do desenvolvimento e altas habilidades ou superdotação, matriculados na rede pública de ensino regular. Garantir a transversalidade das ações da educação especial no ensino regular. Fomentar o desenvolvimento de recursos didáticos e pedagógicos que eliminem as barreiras no processo de ensino e aprendizagem. Assegurar condições para a continuidade de estudos nos demais níveis de ensino.

\section{RESULTADOS}

O conjunto de atividades, recursos de acessibilidade e pedagógicos que caracterizam o Atendimento Educacional Especializado são organizados institucionalmente e prestados de forma complementar ou suplementar à formação dos alunos no ensino regular. A produção e distribuição de recursos educacionais para a acessibilidade incluem livros didáticos e paradidáticos em Braille, áudio e Língua Brasileira de Sinais - LIBRAS, laptops com sintetizador de voz, softwares para comunicação alternativa e outras ajudas técnicas que possibilitam o acesso ao currículo escolar.

A organização e a administração deste espaço são de responsabilidade da gestão escolar e o professor que atua neste serviço educacional deve ter formação para o exercício do magistério de nível básico e conhecimentos específicos de Educação Especial, adquiridos em cursos de aperfeiçoamento e de especialização.

A função do professor do AEE consiste em propor atividades que permitam eliminar barreiras na aprendizagem e otimizar a aprendizagem dos alunos e sua inclusão no ensino regular. Essa ação, certamente, terá uma repercussão positiva no desempenho do aluno na sala de aula comum.

\section{DISCUSSÃO}

O acompanhamento do AEE se organiza a partir de um plano de atendimento educacional especializado que o professor deve elaborar com base nas informações obtidas sobre o aluno e a problemática vivenciada por ele através do estudo de caso. De posse de todas as informações sobre o aluno, bem como dos recursos disponíveis na sala de aula, na escola, na família e na comunidade, o professor do AEE elabora seu plano.

Para elaborar o plano, o professor mobiliza os diferentes recursos disponíveis (escola, comunidade etc.) e faz uma articulação com o professor do ensino comum. 0 professor do AEE prevê um determinado período para o desenvolvimento do seu plano, ao término do qual ele fará uma avaliação no sentido de redimensionar suas ações em relação ao acompanhamento do aluno. 0 acompanhamento é, essencialmente, o desenvolvimento e a avaliação do plano de AEE. 


\section{CONCLUSÕES}

Existem muitos outros aspectos envolvendo as Salas de Recursos Multifuncionais e a Educação Inclusiva em geral, além da sua política de efetivação, que demandam análise, como é o caso, por exemplo, das formas de avaliação da aprendizagem e da concretização da socialização pretendida para os alunos. Desse modo, então, é imprescindível desenvolver novos estudos e pesquisas sobre a referida temática.

\section{REFERÊNCIAS}

[1] ALVES, Denise de Oliveira. Sala de Recursos Multifuncionais: espaços para atendimento educacional especializado. Brasília: Ministério da Educação, Secretaria de Educação Especial, 2006.

[2] BATISTA, Cristina Abranches Mota. Educação Inclusiva: atendimento educacional especializado para a deficiência mental. Brasília: MEC, SEESP, 2005.

[3] MINISTÉRIO DA EDUCAÇÃO. Saberes e práticas da inclusão: avaliação para identificação das necessidades educacionais especiais. 2. Ed., Brasília, Secretaria de Educação Especial, 2006. 


\title{
Capítulo 8
}

\section{A atuação docente em educação física escolar: Um olhar a partir das intenções de pesquisa de publicações acadêmico-científicas}

\author{
Adriana Flávia Neu \\ Eduardo Adolfo Terrazzan
}

Resumo: Este artigo consiste em um estudo de revisão de literatura especializada, com o objetivo de identificar as intenções de pesquisa das produções acadêmico-científicas sobre atuação docente em Educação Física escolar, veiculados em periódicos acadêmico-científicos nacionais, classificados com Qualis A, na área de avaliação da Educação Física, nos últimos cinco anos. Na introdução deste artigo apresentamos um panorama da disciplina de Educação Física na escola, o qual nos mostra que a Educação Física ainda não conquistou uma identidade sólida como componente curricular. Assim, compreender as práticas dos professores de Educação Física pode contribuir para a consolidação da identidade desta disciplina no contexto escolar. A abordagem metodológica utilizada nesta pesquisa é de natureza qualitativa. Estudos de revisão de literatura, que fazem a síntese da produção acadêmica sobre determinado assunto, podem fornecer elementos relevantes para o aperfeiçoamento da pesquisa em determinado campo do saber. Assim, este estudo de revisão de literatura tem como fonte para coleta de informações, 22 artigos (18 pesquisas empíricas e 4 ensaios teórico-conceituais), veiculados na Revista Movimento, de responsabilidade da Universidade Federal do Rio Grande do Sul (UFRGS). 0 instrumento para coleta de informações desta pesquisa consiste em um Roteiro de Análise Textual elaborado e utilizado no âmbito do Grupo de Estudos, Pesquisas e Intervenções "Inovação Educacional, Práticas Educativas e Formação de Professores" - INOVAEDUC, sediado no Núcleo de Estudos em Educação, Ciência e Cultura - NEC. Para este artigo, focou-se no Item 04 do Roteiro para Pesquisas Empíricas (Intenções de pesquisa: Objetivo, Problema e Questões de Pesquisa), e no Item 04 do Roteiro para Ensaios Teórico-Conceituais (Objetivo do Ensaio). Com base nos objetivos dos artigos aqui analisados, foi possível perceber que a maioria dos estudos está voltada a algum aspecto da didática, como por exemplo, estratégias de ensino a partir de um determinado conteúdo, ou sobre a relevância, dificuldades e possibilidades do trabalho de determinados assuntos nas aulas de Educação Física escolar. Também foram percebidas publicações que evidenciavam discussões sobre as atuais práticas avaliativas deste componente curricular, bem como práticas inclusivas nesta disciplina, ressaltando-se as principais potencialidade e fragilidades para que a inclusão aconteça. Ressalta-se também, a necessidade de novas publicações sobre o assunto "atuação docente em Educação Física", para que auxilie na legitimação de práticas inovadoras em Educação Física escolar.

Palavras-chave: Educação Física escolar, Atuação docente em Educação Física, Práticas de professores de Educação Física. 


\section{INTRODUÇÃO}

Para um trabalho de maior relevância, é interessante que se busque o que já foi produzido anteriormente sobre a temática de pesquisa pretendida. Para tanto, objetivou-se neste artigo, identificar as intenções de pesquisa das produções acadêmico-científicas sobre atuação docente em Educação Física escolar, veiculados em periódicos acadêmico-científicos nacionais, classificados com Qualis A, na área de avaliação da Educação Física, nos últimos cinco anos.

Parte-se do pressuposto que a Educação Física vem, desde seus primórdios, enfrentando uma séria crise de identidade. Esta crise está fortemente ligada à falta de definição do que se espera que seja ensinado no componente curricular Educação Física. Como consequência disso, há também certa confusão em relação ao status dessa disciplina na escola.

Bracht (2000) afirma que a Educação Física tem como função o trato pedagógico do movimento humano. E Goellner (2012) assume que a Educação Física é:

[...] uma prática de intervenção social que prescinde de conhecimentos advindos das ciências humanas e naturais para atuar em diferentes elementos que compõe a cultura corporal (o esporte, a dança, o jogo, a ginástica, as lutas, entre outros) no âmbito da educação, da saúde e do lazer. (GOELLNER, 2012, p.37-38).

Apesar de a Educação Física ser composta por diversas práticas pertencentes à cultura corporal, como por exemplo, esportes, danças, jogos, ginásticas, lutas, "atualmente, o esporte é o veiculo mais utilizado como forma de difusão do movimento corporal na escola de $1^{\circ}$ e $2^{\circ}$ graus" (RANGEL BETTI, 1999, p.25). Para mais, a autora recém-citada também indica que os conteúdos ensinados na escola vão além da supremacia do ensino do esporte, isto é, "[...] somente algumas modalidades esportivas tais como o futebol, basquetebol e voleibol fazem parte do conteúdo das aulas de Educação Física. Outras modalidades como o atletismo e a ginástica artística raramente são difundidas entre os escolares desta faixa etária".

A prática hegemônica do esporte nas aulas de Educação Física, abriu espaço, então, para a confusão entre Educação Física e esporte, pensadas muitas vezes como sinônimos. A relação simbiôntica com o esporte resultou em um processo conhecido como a esportivização da Educação Física escolar, o qual começou a ser questionado por volta dos anos 80 caracterizando um movimento renovador da Educação Física brasileira (GONZÁLEZ; FENSTERSEIFER, 2009).

Nesse cenário, a Educação Física escolar parece estar mais ligada à condição de atividade do que a de componente curricular, o que com certeza não corrobora para o entendimento da especificidade da Educação Física escolar e, consequentemente, "a Educação Física não possui um conceito claro e definido do que é o seu objeto de estudo" (GOELLNER et al, 2010, p.391).

Devido à necessidade de a Educação Física passar da condição de "atividade" para a de "componente curricular", esta se encontra, como classificam González e Fensterseifer (2009), "entre o não mais e o ainda não", o que se caracteriza, segundo os autores, como sendo uma prática docente em que não se acredita mais e outra que ainda se tem dificuldades de se pensar e ser desenvolvida.

Na tentativa de caracterizar práticas pedagógicas em Educação Física, Silva e Bracht (2012) identificaram três tipos de prática pedagógica em Educação Física presente atualmente nas escolas. Esses autores salientam que lhes parece possíveis à caracterização, mesmo que de forma reducionista.

O primeiro tipo de prática pedagógica, segundo Silva e Bracht (2012, p. 77), é caracterizada pela "tradição que se instalou nas escolas e que foi construída nas décadas de 70 e 80 ". Os professores que compartilham desta prática costumam organizar as aulas de Educação Física na ideia de que o papel dessa disciplina é o ensino e a prática de alguns esportes.

O segundo tipo de prática é nomeada por Silva e Bracht (2012) como "professor rola bola" ou "pedagogia da sombra". Neste tipo de prática, os professores não tem pretensão maior do que ocupar os alunos com atividades, assumindo, involuntariamente, o papel de administradores dos materiais, ou até mesmo o papel de recreacionista deixando com que o aluno extravase seu tédio produzido nas outras disciplinas. 
Já o terceiro tipo de prática pedagógica em Educação Física escolar, contrapõe-se aos dois primeiros tipos (SILVA; BRACHT, 2012). Neste tipo de prática têm-se professores que buscam:

a) inovar os conteúdos da Educação Física, ampliando-os para além dos tradicionais esportes, tematizando outras manifestações da cultura corporal de movimento, além de considerar como conteúdos de aula os aspectos ligados ao conhecimento sobre a cultura corporal de movimento, como conhecimentos fisiológicos, antropológicos, sociológicos, etc. tratando-os contextualizadamente, portanto, articulando teoria e prática; b) modificar o trato deste conteúdo, não mais se resumindo a apresentar os gestos considerados corretos, e sim, envolvendo o aluno como sujeito do conhecimento, construindo um ambiente de co-gestão das aulas; c) utilizar diferentes formas de avaliação que envolvam o aluno nas decisões do que avaliar, como avaliar e, mesmo, no próprio ato de avaliação (auto-avaliação); d) articular a EF [Educação Física] de forma mais clara e orgânica ao projeto pedagógico da escola. (SILVA; BRACHT, 2012, p.77-78).

Então, o ensino da "Educação Física tem no movimento tanto um meio quanto um fim para atingir seu objetivo educacional dentro do contexto escolar" (RANGEL BETTI, 1999, p.25). Por isso que a Educação Física escolar deve favorecer o desenvolvimento do aluno, de modo a propiciar que este descubra o sentido das práticas que está desenvolvendo na escola. Além disso, o aluno deve ter a oportunidade de vivenciar diversas práticas durante sua escolaridade, visto a amplitude da cultura corporal de movimento.

\section{METODOLOGIA}

Esta pesquisa configura-se em uma pesquisa de natureza qualitativa. Segundo Flick (2009) a pesquisa qualitativa possui alguns aspectos essenciais que consistem em: apropriabilidade de métodos e teorias; perspectivas dos participantes e sua diversidade; reflexividade do pesquisador e da pesquisa; e variedade de abordagens e de métodos. Para Gibbs (2009) está cada vez mais difícil encontrar uma definição para a pesquisa qualitativa pela variedade de pesquisadores e abordagens existentes e que, apesar deste tipo de pesquisa ter diversos enfoques, pode-se identificar algumas características comuns.

Esta pesquisa tem o seguinte problema de pesquisa: Quais os principais objetivos dos estudos veiculados em periódicos acadêmico-científicos, avaliados em Educação Física e classificados pela Capes com estrato A, sobre atuação docente em Educação Física escolar?

Para responder o problema de pesquisa utilizamos como fontes para coleta de informações, artigos científicos veiculados em Periódicos Acadêmico-Científicos (PAC) nacionais/brasileiros, com estrato A, segundo a Classificação de Periódicos no quadriênio 2013-2016, disponível na plataforma Sucupira na área de avaliação de Educação Física. A busca se deu em PAC com abrangência nacional, pois a intenção é identificar o que se tem produzido e estudado no Brasil sobre a atuação docente em Educação Física.

Entende-se que estudos de revisão de literatura podem contribuir para a descrição da produção acadêmico-científica de um determinado assunto, e o periódico constitui-se como uma fonte privilegiada para tal. Catani, em 1996, já evidenciava que:

De fato, as revistas especializadas em educação, no Brasil e em outros países, de modo geral, constituem uma instância privilegiada para a apreensão dos modos de funcionamento do campo educacional enquanto fazem circular informações sobre o trabalho pedagógico e o aperfeiçoamento das práticas docentes, o ensino específico das disciplinas, a organização dos sistemas, as reivindicações da categoria do magistério e outros temas que emergem do espaço profissional. (CATANI, 1996, p.117).

De acordo com o critério de seleção dos PAC's para compor a amostra deste estudo, identificamos apenas um PAC brasileiro, isto é, na Classificação de Periódicos no quadriênio 2013-2016, disponível na plataforma Sucupira, na área de avaliação de Educação Física, há apenas a Movimento (Revista mantida pela Universidade Federal do Rio Grande do Sul - UFRGS), a qual está classificada com estrato A2. 
Após a seleção do PAC que fará parte da nossa amostra, foi selecionado alguns termos de busca, os quais são: "Professor(es) de Educação Física", "Educação Física escolar", "Docência em Educação Física", "Prática docente em Educação Física", "Atuação do professor de Educação Física" e "Ensino de Educação Física". Após definidos os termos de busca, procedeu-se à identificação de artigos que atendiam a esses termos de busca na revista Movimento. Então, foram verificados todos os números e volumes desde 2012 até o mais atual deste Periódico.

0 critério de identificação dos artigos foi definido pela presença de, pelo menos um, dos termos de busca no título, e/ou resumo e/ou palavras-chave. Identificou-se 81 (oitenta e um) artigos que atendiam ao critério de identificação e, foi feito download deles para posterior leitura.

Com a leitura minuciosa dos artigos identificados, percebeu-se que nem todos tratavam de aspectos relativos à atuação docente em Educação Física, sendo selecionados 22 (vinte e dois) artigos, e o restante descartados. De acordo com isso, dos 22 artigos selecionados da Revista Movimento que dão enfoque à atuação do professor de Educação Física na escola, 18 (dezoito) se caracterizam como pesquisas empíricas e 4 (quatro) como ensaios teórico-conceituais.

0 instrumento para coleta de informações desta pesquisa consiste em um Roteiro de Análise Textual elaborado e utilizado no âmbito do Grupo de Estudos, Pesquisas e Intervenções "Inovação Educacional, Práticas Educativas e Formação de Professores" - INOVAEDUC, sediado no Núcleo de Estudos em Educação, Ciência e Cultura - NEC.

Para a elaboração deste artigo e para alcançar o objetivo proposto, focou-se no Item 04 do Roteiro para Pesquisas Empíricas que diz respeito à descrição das Intenções de Pesquisa, isto é, ao Objetivo de Pesquisa, ao Problema de Pesquisa e às Questões de Pesquisa; e no Item 04 do Roteiro para Ensaios Teórico-Conceituais, que se refere à descrição do Objetivo do Ensaio. A seguir, apresenta-se a análise detalhada destes Itens, em cada artigo que compõe a amostra deste estudo.

\section{RESULTADOS E DISCUSSÃO}

Há uma linearidade na quantidade de publicações ao longo dos anos. Os 22 artigos selecionados para compor a amostra deste trabalho investigaram algum aspecto relacionado à atuação docente em Educação Física no contexto escolar, verificando-se, basicamente, sobre avaliação, inclusão escolar e aspectos relacionados à didática na Educação Física escolar.

Publicado em 2016, no artigo de Andrade e Freitas, é discutido o processo e as políticas para inclusão de alunos com deficiência, na rede regular de ensino. 0 texto tinha por objetivo analisar como os professores de Educação Física agem para a inclusão de alunos com deficiência em suas aulas e, os autores puderam perceber que as práticas dos professores viabilizaram condições favoráveis à participação dos alunos com deficiência, tendo, como os demais, possibilidades de aprendizagem na escola regular.

Com objetivo semelhante, Chicon et al (2016) se propôs a descrever e analisar a ação mediadora dos professores/brinquedistas no processo de interação de alunos com e sem deficiência na brinquedoteca. Estes autores consideram importante a ação mediadora dos professores/brinquedistas para que o processo de inclusão se consolide e para que haja avanços no aprendizado e desenvolvimento da criança que não ocorreriam espontaneamente.

Já Alves e Duarte (2012) se detiveram em observar o processo de inclusão de uma criança com Síndrome de Down nas aulas de Educação Física, a fim de identificar as dificuldades e facilidades enfrentadas por esta criança durante este processo. Perceberam que há muitas lacunas ainda a serem preenchidas a respeito do processo inclusivo e que há a necessidade de serem feitos novos estudos sobre este tema para a melhoria do processo inclusivo.

Acredita-se que há muito em comum entre os três textos, uma vez que todos investigam o processo de inclusão dos alunos partindo da observação da ação dos professores de Educação Física em suas aulas.

Florência e Gomes-da-Silva (2017) se questionaram sobre como a pesquisa colaborativa poderia contribuir para a ressignificação da prática pedagógica e da produção do saber do professor de Educação Física e, a partir disso procuraram analisar a contribuição da pesquisa colaborativa para a articulação entre o fazer cotidiano do professor de Educação Física ao tratar o conteúdo dança e o processo de reconhecimento e reconstrução de novos conhecimentos com rigor científico. 
Consideraram a pesquisa colaborativa como uma possibilidade para se pensar uma prática pedagógica mais reflexiva, elemento essencial para a ressignificação do ato pedagógico, segundo as narrativas de formação. A partir desta pesquisa, Florência e Gomes-da-Silva (2017) sugeriram também a produção de novas pesquisas que possam contribuir efetivamente para a formação de professores mais críticos e reflexivos.

Utilizando-se da vertente da compreensão, baseados em algumas ideias de Pierre Bourdieu, Rufino, Benites e Neto (2017) buscaram, em seu ensaio teórico-conceitual, analisar e compreender as possibilidades de utilização das estratégias da AP [Análise das Práticas] para o engendramento da epistemologia da prática profissional, buscando contribuir com o desenvolvimento dos processos de formação de professores no campo da Educação Física.

A pesquisa de Barroso e Darido (2016) teve o propósito de interligar dois elementos na prática pedagógica do professor de Educação Física - o sistema de classificação do esporte e o livro didático. Para tal, os autores objetivaram investigar quais modificações foram realizadas pelos professores de Educação Física em relação ao material didático para o ensino do sistema de classificação do esporte no 8o e 9o anos do ensino fundamental, de acordo com as suas necessidades, e se essas alterações atendem a outro grupo de professores que atuam no mesmo nível de ensino.

A partir de um estudo de revisão de literatura na revista Éducation Physique et Sport, Barragán et al (2016) analisaram a produção disponível sobre a importância do circo contemporâneo. A maioria dos artigos analisados foram relatos de experiências de professores sobre organizações do conteúdo em unidades didáticas, bem como questões relativos ao ensino do circo na Educação Física escolar.

Em 2016, Frabri, Rossi e Ferreira realizaram uma pesquisa que teve por objetivo identificar e analisar os episódios, em formato de casos de ensino, escritos por alunos do ensino médio sobre suas experiências nas aulas de Educação Física. Esses autores se valeram das experiências dos alunos para caracterizar a atuação do professor de Educação Física na escola.

Verificar, com base no levantamento de artigos publicados entre 2005 e 2013, em periódicos científicos da área, se a modalidade esportiva atletismo tem sido efetivamente abordada em aulas de Educação Física e sob quais características, foi o objetivo de Mota E Silva et al (2015). Com base no estudo de revisão de literatura feito por estes autores, parece ter havido um aumento da incidência do atletismo nas aulas de Educação Física da educação básica, que pode ter acontecido em detrimento da maior conscientização da importância do ensino desta modalidade nas escolas. Apesar do aumento da incidência do ensino desta modalidade, falta de materiais e locais apropriados para o ensino do atletismo ainda são algumas das dificuldades enfrentadas por estes professores. Essas dificuldades são grandemente atribuídas à déficits na formação inicial e/ou continuada de professores.

A partir de questionamentos como: 0 que pensam esses professores sobre a utilização do texto como recurso didático? Como eles têm utilizado o texto nas aulas? Qual sua percepção sobre o trabalho que realizam?, Vieira, Freire e Rodrigues (2015) realizaram uma pesquisa em que objetivaram analisar o texto escrito como recurso didático aplicado no ensino da EF e compreender as percepções e práticas construídas por professores que utilizam esse recurso em suas aulas. Com a realização deste estudo, os autores puderam perceber que, apesar da resistência dos alunos quanto a utilização de textos para o ensino de conteúdos da Educação Física escolar, este procedimento didático contribui para a construção de um processo pedagógico mais coerente também com os objetivos propostos pela escola e pela Educação Física.

Gomes da Silva, Imbiriba E Silva e Lüdorf (2015), ao buscarem compreender e discutir quais aspectos relacionados ao corpo na contemporaneidade são destacados pelos professores nas aulas de Educação Física do ensino médio, sob a ótica do próprio docente, identificaram que a estética e a saúde sobressaem como os aspectos mais valorizados no corpo atualmente neste recorte da realidade escolar do Rio de Janeiro.

Qual a visão dos professores sobre o processo de ensino e de aprendizagem do basquetebol e como a Educação Física Escolar pode contribuir para este processo foram as questões norteadoras do estudo realizado por Severino, Gonçalves e Darido, em 2014. Ao investigar a visão dos professores quanto ao processo de ensino e de aprendizagem do basquetebol nas aulas de Educação Física em ambiente escolar no município de Volta Redonda - RJ, bem como a sua prática por meninas, os autores identificaram a transposição do conteúdo basquetebol além das quadras da escola. 
Considerações acerca do comportamento da mídia e a realização de políticas públicas são exemplos de como esporte pode fomentar discussões que transcendem aspectos associados apenas às características específicas de cada modalidade (SEVERINO; GONÇALVES; DARIDO, 2014).

Beltrão (2014), ao refletir, em seu ensaio teórico-conceitual, sobre as influências exercidas pelo ENEM e pelos vestibulares sobre a educação escolar, analisando seus significados e as possíveis implicações na Educação Física escolar, entendeu que, por conta da dimensão que o exame vem ganhando na sociedade brasileira, torna-se necessário o desenvolvimento de estudos empíricos para acompanhar como alunos e professores vão se portar frente à incorporação dos conhecimentos da cultura corporal no ENEM.

Matos et al (2013) ressaltam em seu artigo a relevância de estudos de revisão de literatura, pois estes podem dar visibilidade a temas recorrentes na campo acadêmico, como também indicar temas que não são abordados frequentemente. Baseados nessa premissa, estes autores objetivaram analisar as produções acadêmicas que tratam sobre conteúdos de ensino da Educação Física escolar, referentes ao período de 1981 a 2010. Embora as discussões relacionadas com o Esporte tenham assumido centralidade nos debates da área a partir de 1980, questionando-o como prática escolar e colocando em voga a legitimidade da Educação Física, foi observado o impacto que esse conteúdo ainda obtém na produção. Para além da sua representatividade numérica, o panorama evidenciado nos leva a discutir a diversidade de práticas possível à Educação Física escolar, haja vista alguns trabalhos terem se dedicado ao trato pedagógico de diferentes possibilidades de intervenção (MATOS et al, 2013).

Neto et al (2013), ao problematizarem, em seu ensaio teórico-conceitual, sobre o ensino de temas referentes à dinâmica do ambiente, compreendendo-os a partir do trabalho concreto de professores de EF, que os identificaram como "demandas ambientais", foram levados a debater sobre a construção da identidade profissional e pessoal ao longo da vida.

No ensaio teórico-conceitual de Morschbacher e Marques (2013), que objetivou discutir acerca do distanciamento e das possibilidades de aproximação entre a prática pedagógica cotidiana no contexto da escola e as propostas pedagógicas críticas da Educação Física, considerando especificamente a Teoria Crítico-emancipatória e Didática Comunicativa, foi reiterado o posicionamento de que a superação do distanciamento evidenciado entre as propostas pedagógicas críticas da Educação Física e a prática pedagógica concreta desta disciplina escolar encontra-se, entre outras questões, na necessidade de "retorno" e/ou "ida" ao estudo dessas proposições e de suas teorias de base e na ressignificação do diálogo entre o meio acadêmico e a escola.

Com o objetivo de compreender a presença e o tratamento do conteúdo Esporte, sustentado por uma prática pedagógica "inovadora", nas turmas de 5 a a $8^{\mathrm{a}}$ séries da Escola Estadual de Ensino Fundamental Chico Mendes do município de Ijuí/RS, Carlan, Kunz e Fensterseifer (2012) realizaram uma pesquisa a partir da prática pedagógica de um determinado professor, que acredita não somente na dimensão do conteúdo e na organização/planejamento das aulas, mas fundamentalmente na sua conduta pedagógica na abordagem do esporte enquanto conteúdo, pautado e comprometido com a formação humana. As ações realizadas pelo professor sujeito da pesquisa, confirmaram que ensinar o conteúdo Esporte pode ir além do ensino da prática com um fim em si mesmo.

A partir da análise de conteúdo das entrevistas realizadas, Valdivia-Moral et al (2012) buscaram "Conocer cual es la concepción general del profesorado de EF [Educação Física] sobre la coeducación en EF y que estrategias metodológicas utiliza el profesorado para trabajarla" (p.200). Esta pesquisa partiu da multiplicidade de significados atribuída ao termo "coeducación", o qual é geralmente confundido com igualdade de gênero, igualdade no acesso aos recursos, bem como igualdade no tratamento dos alunos. Ao final da pesquisa, Valdivia-Moral et al (2012) afirmam que os professores de Educação Física não possuem uma ideia formada sobre o termo, o que afeta questões relativas ao ensino e aprendizagem dos alunos.

Devido às mídias ocuparem um papel de destaque na sociedade, influenciando na maneira como as pessoas veem e atuam no ambiente em que vivem, Diniz, Rodrigues e Darido (2012) identificaram resistência ao desenvolvimento de atividades de leituras em aulas de Educação Física, isto é, ao desenvolvimento da dimensão conceitual, uma vez que os alunos ansiavam a todo momento pelas atividades práticas na quadra, tendo com destaque a prática do futsal. Isto pode ser percebido por Diniz, Rodrigues e Darido (2012) ao realizarem sua pesquisa que objetivava analisar algumas possibilidades e dificuldades de uma proposta de aulas desenvolvida em uma escola pública, em um município do interior de São Paulo, que abordou conteúdos da cultura corporal por meio de notícias publicadas pelo Jornal A Folha de São Paulo nas aulas de Educação Física. 
A partir deste estudo, os autores sugerem o desenvolvimento de estudos que problematizem a mídia no ambiente escolar, a fim de favorecer a construção de diversas estratégias que possam contribuir com o trabalho do professor.

Wittizorecki, Neto e Bossle (2012) realizaram uma pesquisa com o intuito de compreender, através de seis histórias de vida de professores de Educação Física da Rede Municipal de Ensino de Porto Alegre (RMEPOA), que mudanças sociais influenciam o seu trabalho docente na escola e, como esses professores experimentam tais mudanças. Este objetivo de pesquisa foi delineado a partir dos seguintes questionamentos: Quais mudanças sociais influenciam o seu trabalho docente na escola? Como [os professores] experimentam estas mudanças, produzindo respostas e enfrentamentos às demandas sociais, culturais e educacionais na comunidade escolar em que atuam? Para os autores desta pesquisa, a pesquisa com histórias de vida revela-se como uma potencialidade para atuar no binômio investigação/formação.

Como a produção do conhecimento no campo da avaliação na Educação tem sido objeto de intensos debates no Brasil desde a década de 1930, Santos et al (2015) procuraram responder como a Educação Física tem enfrentado a questão da avaliação no cotidiano escolar. Para tal, seu estudo buscou discutir sobre as possibilidades e as necessidades de se produzir práticas avaliativas que levem em consideração os saberes valorizados pela educação escolarizada e as especificidades da Educação Física como componente curricular.

Analisar, por meio das narrativas autobiográficas e das memórias de alunos do curso de formação inicial em Educação Física, as experiências de avaliação do processo ensino-aprendizagem vivenciadas nas aulas de Educação Física na Educação Básica, foi o objetivo da pesquisa empírica realizada por Santos e Maximiano (2013). A maior parte das narrativas remeteu a ações avaliativas fundamentadas em provas práticas e escritas, juntamente com a atribuição de notas por comportamentos e atitudes sem um registro sistemático. Estas formas de avaliar podem nos levar a questionar o estatuto epistemológico de que trata a Educação Física no contexto escolar. Assim sendo, precisam-se criar possibilidades avaliativas que potencializem e dê visibilidade à especificidade da Educação Física como componente curricular.

\section{CONCLUSÕES}

Com base nos objetivos dos artigos aqui analisados, que, de certa forma, apresentam um panorama sobre as intenções de pesquisa sobre a atuação do professor de Educação Física nas escolas, foi possível perceber que a maioria dos estudos está voltada a algum aspecto da didática, como por exemplo, estratégias de ensino a partir de um determinado conteúdo, ou sobre a relevância, dificuldades e possibilidades do trabalho de determinados assuntos nas aulas de Educação Física escolar.

E, em número bem menos expressivo, tem-se, neste periódico, publicações sobre a avaliação em Educação Física. Estas publicações referem-se às discussões sobre as atuais práticas avaliativas neste componente curricular, bem como sobre a necessidade de serem repensadas as formas de avaliação existentes, de modo a contribuir para o estabelecimento da identidade da Educação Física na escola.

Já em relação à inclusão as aulas do componente curricular de Educação Física, percebeu-se que os artigos analisados referem-se para a análise das práticas inclusivas nesta disciplina, ressaltando-se as principais potencialidade e fragilidades para que a inclusão aconteça.

O panorama evidenciado a partir dos artigos que compuseram a amostra, nos leva a pensar sobre a diversidade de práticas para a Educação Física escolar, já que a maioria dos trabalhos se dedicou sobre as diferentes possibilidades de intervenção durante a atuação docente em Educação Física escolar. Além disso, acredita-se na relevância da realização de novos estudos sobre este tema, de modo a auxiliar na legitimação de práticas inovadoras em Educação Física escolar. 


\section{REFERÊNCIAS}

[1] BRACHT, Valter. Educação Física \& Ciência: cenas de um casamento (in)feliz. Revista Brasileira de Ciências do Esporte. Porto Alegre, v.22, n.1, p.53-63, 2000. Disponível em: <http://revista.cbce.org.br/index.php/RBCE/article/view/753>. Acesso em: 17 mar. 2017.

[2] CATANI, Denice Barbara.A imprensa periódica educacional: as revistas de ensino e o estudo do campo educacional. Educação e Filosofia. Uberlândia, v.10, n.20, p.115-130, 1996. Disponível em: <http://www.seer.ufu.br/index.php/EducacaoFilosofia/article/viewFile/928/842>. Acesso em: 08 set. 2017.

[3] FLICK, Uwe. Introdução à pesquisa qualitativa. 3 ed. Porto Alegre: Artmed, 2009.

[4] GIBBS, Graham. Análise de dados qualitativos. Porto Alegre: Artmed, 2009.

[5] GOELLNER, Silvana Vilodre; Reppold Filho, Alberto Reinaldo; Fraga, Alex Branco; Mazo, Janice Zarpellon; Stigger, Marco Paulo; Molina Neto, Vicente. Pesquisa qualitativa na Educação Física Brasileira: marco teórico e modos de usar. Revista da Educação Física. Maringá, v.21, p.231-410, 2010. Disponível em: <http://periodicos.uem.br/ojs/index.php/RevEducFis/article/viewFile/8682/5829>. Acesso em: 17 mar. 2017.

[6] GOELLNER, Silvana Vilodre. A importância do conhecimento histórico na formação de professores de Educação Física e a desconstrução da história no singular. Revista Kinesis. Santa Maria, v.30, n.1, p.37-55, 2012.

[7] GONZÁLEZ, Fernando Jaime; Fensterseifer, Paulo Evaldo. Entre o "não mais" e o “ainda não": pensando saídas do não-lugar da EF escolar I. Cadernos de Formação RBCE, Porto Alegre, p.9-24, 2009. Disponível em: <http://revista.cbce.org.br/index.php/cadernos/article/view/929>. Acesso em: 24 mar. 2017.

[8] RANGEL BETTI, Irene Conceição. Esporte na escola: mas é só isso, professor? Motriz, Rio Claro, v.1, n.1, p.2531, 1999. Disponível em: <https://fefd.ufg.br/up/73/o/Texto_105_-_Esporte_na_escola_Mas_s_isso_professor__Irene_Concei_o_Rangel_Betti.pdf>. Acesso em: 22 mar. 2017.

[9] SILVA, Mauro Sérgio da; BRACHT, Valter. Na pista de práticas e professores inovadores na Educação Física escolar. Revista Kinesis, Santa Maria, v.30, n.1, 2012. 


\title{
Capítulo 9
}

\section{As aulas de educação física a partir do tema futebol: Relato de vivências no estágio supervisionado}

\author{
Ana Gabriela Alves Medeiros \\ Sirlânia Souza Pereira \\ Geovânia Silva Mota \\ Marlon Messias Santana Cruz
}

Resumo: Este trabalho refere-se a um relato das ações pedagógicas desenvolvidas no contexto do estágio supervisionado e tem como objetivo elucidar como se deu a prática pedagógica no âmbito do estágio curricular do curso de Licenciatura em Educação Física do Campus XII da Universidade do Estado da Bahia (UNEB), que foi desenvolvido em uma Escola da Rede Municipal da cidade de Guanambi/BA, evidenciando os avanços e os limites que permearam tal prática. As nossas intervenções tiveram como base a Perspectiva Cultural da Educação Física, proposta por Neira e Nunes $(2008$; 2009) que se fundamenta nos estudos culturais e o multiculturalismo crítico, esse currículo entende que o/a discente vive em uma realidade repleta de significações e estas significações adentram a realidade escolar, logo elas devem ser problematizadas, discutidas e contextualizadas, sem adjetivá-las como certas ou erradas para tal contexto. A partir do mapeamento identificamos que o futebol seria a temática a ser problematizada e vivenciada durante as nossas intervenções, dando uma atenção especial para questões como violência no futebol, a influência da mídia no futebol e a presença da mulher nesta manifestação da cultura corporal. Conclui-se que mesmo nos deparando com algumas dificuldades, a experiência no contexto do estágio supervisionado nos proporcionou uma série de conhecimentos importantes para o exercício profissional. As experiências vivenciadas no contexto da sala de aula nos levaram a refletir sobre a necessidade de se pensar em um trabalho docente que valorize a diversidade cultural e que acredite na construção de uma sociedade justa e democrática.

Palavras-Chave: Estágio supervisionado; Educação Física Escolar; Futebol. 


\section{INTRODUÇÃO}

0 presente estudo trata-se de um relato das práticas de ensino desenvolvidas no contexto do estágio supervisionado, que foi realizado em uma escola da rede municipal da cidade de Guanambi - Bahia.

O estágio curricular é entendido por Pimenta e Lima (2004) e por Lima (2008) como um campo de conhecimento e eixo curricular central nos cursos de formação docente, esse componente possibilita que sejam trabalhados aspectos imprescindíveis para a construção da identidade e saberes indispensáveis no exercício profissional. Nesse sentido, Pimenta e Lima (2005/2006) complementam afirmando que esse componente curricular tem a finalidade de aproximar o/a graduando/a da realidade na qual atuará, para que ele/a possa conhecer e reconhecer a escola como seu futuro campo de atuação.

A nossa prática pedagógica foi orientada pelos princípios da Perspectiva Cultural da Educação Física, que se trata de uma teoria pós-crítica, proposta por Marcos Garcia Neira e Mário Luiz Ferrari Nunes, com as obras Pedagogia da Cultura Corporal: Críticas e Alternativas (2008), e Educação Física, Currículo e Cultura (2009), que tem como base os estudos culturais e o multiculturalismo crítico.

Esta perspectiva busca promover a interação entre os diversos grupos culturais através de suas práticas corporais, independentemente de quais valores e normas tais práticas trazem consigo. Nesse sentido, esse currículo pretende dar voz às diferentes culturas no mesmo espaço, ao mesmo tempo. Além de tematizar as relações de poder que se fazem presentes nas questões de gênero, etnia, sexismo, classe, idade, raça, dentre outras (NUNES; RUBIO, 2008).

A partir do mapeamento e das nossas observações identificamos que o futebol seria a temática a ser problematizada no decorrer das nossas intervenções. Com isso, esse trabalho objetiva elucidar como se deu a prática pedagógica no âmbito do estágio curricular, evidenciando os avanços e os limites que permearam tal prática, bem como refletir a luz do referencial orientador a respeito da violência no futebol no contexto das aulas de Educação Física.

\section{DELINEANDO 0 PERCURSO}

0 estágio curricular obrigatório foi desenvolvido em uma turma do $4^{\circ}$ ano do ensino fundamental. Para iniciar as atividades, buscamos no primeiro momento observar algumas aulas de Educação Física a fim conhecer a dinâmica das aulas, bem como nos aproximar minimamente dos/as alunos/as.

Em seguida, mapeamos as práticas corporais que fazem parte do universo cultural dos/as alunos/as, por meio de desenhos e questionários, e através desse mapeamento identificamos o futebol como temática a ser problematizada, e a partir dessa temática vivenciamos, problematizamos e refletimos acerca de algumas questões como gênero, etnia, classe social, raça, dentre outras.

Vale salientar que, por mais que essa manifestação da cultura corporal seja hegemônica na escola, muitas representações culturais que a permeia são desconsideradas.

No decorrer das nossas observações, notamos que a violência tanto física quanto verbal era característica marcante nas aulas de Educação Física, especialmente, durante as vivências. Diante dessa situação, optamos por discutir durante as nossas intervenções acerca da violência no futebol, do flair play, da presença da mulher no futebol e da influência da mídia no futebol.

Para conseguirmos dinamizar e ilustrar as nossas aulas, lançamos mão de alguns instrumentos tais como projetor de slides, notebook, caixa de som, bolas, cones, dentre outros.

\section{AS QUESTÕES QUE PASSAM DESPERCEBIDAS NAS AULAS DE EDUCAÇÃO FÍSICA}

As nossas ações pedagógicas tomou a realidade cultural dos/as alunos como ponto de partida, com isso para identificarmos qual seria o conteúdo a ser tematizado foi realizado um mapeamento, que é entendido por Escudero e Neira (2011) como uma ferramenta de coleta de informações relativas à cultura dos/as alunos/as, ocasião em que o/a professor/a adentra a realidade dos/as discentes para identificar o repertório acessado pelos/as estudantes. $\mathrm{E}$ o futebol foi a temática identificada.

Vale ressaltar que o futebol é o esporte mais popular do nosso país, e essa popularidade se faz presente na escola. É comum vermos as aulas de Educação Física serem reduzidas à práticas esportivas, onde se destaca o futebol. 
Com isso, pode-se afirmar que os discursos hegemônicos são, muitas vezes, reproduzidos e disseminados pela instituição escolar e, assim, o currículo vigente prioriza algumas representações culturais em detrimento de outras, fazendo com que os grupos excluídos socialmente não tenham voz nesse currículo. "Os diferentes tentam afirmar suas identidades, porém, deparam-se com os discursos provindos de setores privilegiados que lhes conferem estigmas e estereótipos pejorativos" (NEIRA; NUNES, 2009, p. 19).

As duas primeiras semanas do estágio foram destinadas à observação, para que pudéssemos conhecer minimamente a realidade das aulas de Educação Física e nos aproximar dos/as alunos/as. Sendo assim, notamos que as questões de gênero eram acentuadas nas aulas, além disso, os/as alunos/as eram muito violentos/as quando estavam jogando. A partir desse fato, optamos por problematizar nas nossas aulas a violência no futebol, a mulher no futebol e a influência da mídia nesse esporte.

Começamos então a nossa intervenção com a seguinte pergunta:

Figura 1 - Questão inicial da intervenção

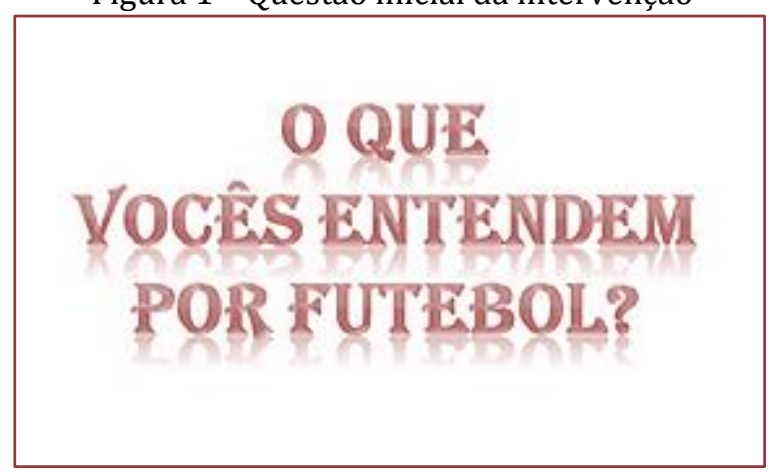

Antes de qualquer resposta, surgiram alguns comentários maldosos, tal como: "as meninas não entendem nada". Diante disso, perguntamos: quem disse a você que meninas não entendem nada de futebol? Você já se perguntou o porquê delas não entenderem? Discutimos minimamente a respeito dessas questões, pois falaríamos disso posteriormente.

Nesse primeiro momento, discutimos sobre a violência no futebol, porque durante as nossas observações, no momento da vivência um aluno esbarrou no outro e este caiu e ficou no chão chorando, e o outro tocou a bola para o seu parceiro que acabou fazendo o gol, e saíram comemorando. Nesse momento intervimos pedindo para parar o jogo, pois o colega estava machucado. Quase fomos agredidas, alguns alunos se dirigiram a nós com o tom de voz bem elevando e um tanto quanto agressivo: "qual é professora? Foi só uma 'trombada' não foi falta não". Diante da situação respondemos que não havíamos falado que tinha sido falta só pedimos para parar o jogo porque o colega estava machucado. E foram, mais uma vez, agressivos com palavras e disseram: "no campo o juiz não para o jogo não, ele só tira o jogador do campo e o jogo continua normalmente". Dada à situação perguntamos: onde está o campo? Onde está o juiz? E complementamos: já que vocês assistem os jogos de futebol na TV, vocês já devem ter ouvido falar em fair play. E nisso explicamos minimamente o que significa fair play. Depois disso, o jogo continuou, e no decorrer deste, eles falaram muitos palavrões, e agrediam os colegas verbalmente a todo o momento.

Partido disso, utilizamos algumas falas e situações dessa aula para introduzir as nossas discussões acerca da violência no futebol. 
Figura 2 - Tematizando a violência no futebol

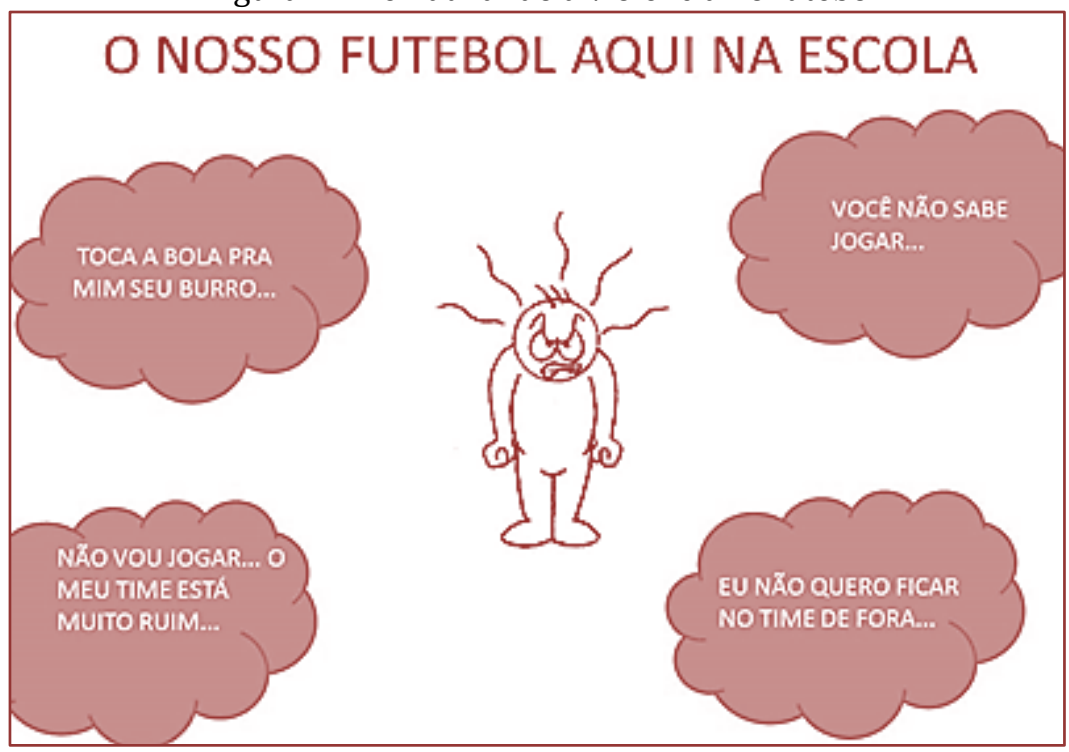

Figura 3 - Tematizando a violência no futebol

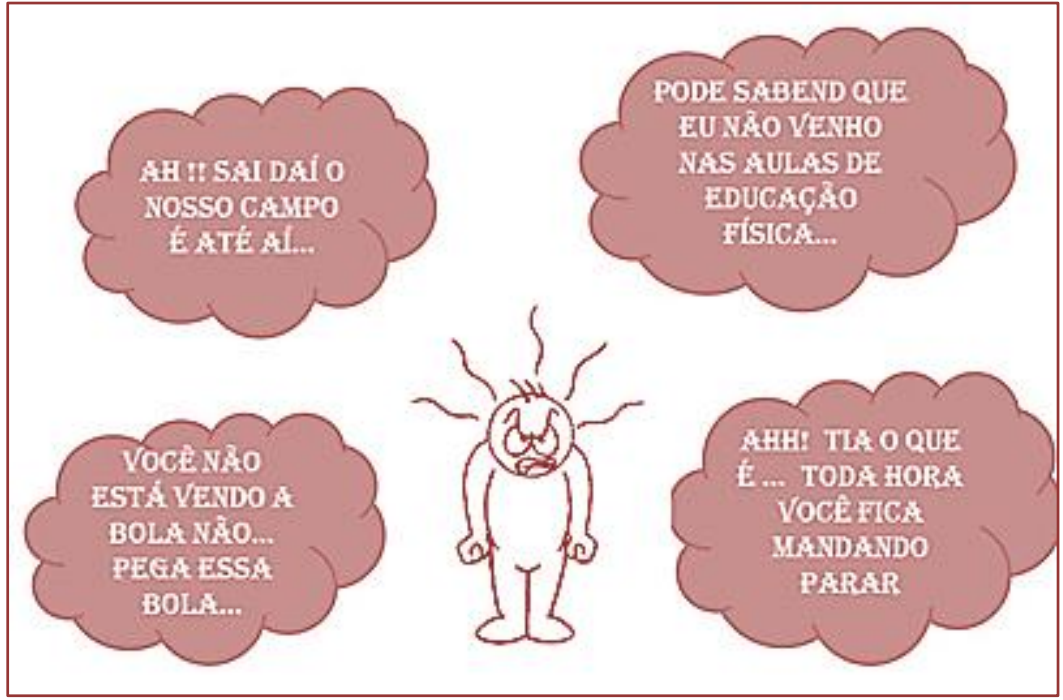

Vale ressaltar que o futebol meche com as emoções do brasileiro, não é em vão que o Brasil foi, por muito tempo, considerado o país do futebol, pois o futebol era a grande paixão do brasileiro. Contudo, as expressões que permeiam o futebol são de ordem variada, como afirmam Moraes e Moraes (2012, p. 149) "paralelamente aos momentos de alegrias, satisfação e lazer proporcionados pelas equipes dos times, são recorrentes as manifestações de violência e vandalismo, transformando estádios em templos de tensão social".

Com base em alguns estudos, pode-se afirmar que a mídia e as tecnologias, de certa forma, facilitam a organização de atos violentos, pois depois da grande repercussão que a mídia deu a violência das torcidas organizadas, o número de integrantes dessas torcidas aumentou significativamente. Levando em conta essa influência da mídia Moraes e Moraes (2012, p. 149) salientam que 
Confrontos violentos entre torcidas organizadas não ocorrem ao acaso. A utilização da tecnologia da informação e comunicação permite que a organização das manobras das "torcidas organizadas" torne-se mais aprimorada, especializada, verdadeira operação de guerra.

Levando em consideração algumas reações e falas dos alunos diante de alguns vídeos e fotos que utilizamos no decorrer das aulas, notamos que muitos atos dos estudantes são fortemente influenciados pela mídia, pois eles relatavam com frequência que era comum os colegas cometerem alguma infração e negarem, assim como no futebol televisionado.

Quando discutimos sobre o fair play percebemos que muitos alunos se surpreenderam, pois boa parte da turma não sabia do que se tratava, até porque muito pouco se percebe do fair play no futebol brasileiro.

Para contextualizarmos a presença da mulher no futebol, utilizamos um texto de Fernanda P. de Brito (2013) intitulado Por mais que não apareçam... mulheres também jogam futebol, esse texto de certa forma encorajou algumas meninas da turma, pois a participação delas era um tanto quanto tímida, mas depois da leitura, elas relataram como os colegas as tratavam. E pelos relatos percebemos que a violência verbal e as questões de gênero eram problemáticas evidentes daquela realidade.

Todas as nossas aulas foram divididas em três momentos: (1) discussão, problematização e contextualização, (2) vivência e (3) reflexão acerca da vivência. Em praticamente todas as aulas, nos momentos de discussão, problematização e contextualização grande parte dos alunos intervia para perguntar que horas iríamos "jogar".

Quase sempre, assim que chegávamos à escola, um grupo se dirigia até nós e perguntavam: Ei tia vai ter Educação Física hoje? Dizíamos que sim, mas quando começávamos a aula problematizando alguma temática em sala, eles falavam: ué tia, você não disse que teria Educação Física hoje? Foi só a partir disso que entendemos que Educação Física para eles era somente as aulas práticas.

Durante as vivências, por mais que ressaltássemos que não era um momento de competição, que não estávamos em um campo de futebol, que aquele espaço não havia nenhum jogador profissional, que não queríamos saber quem era o melhor jogador da turma, eles/as não compreendiam. Em praticamente todas as aulas eles/as brigavam porque um time era mais forte do que o outro, ou porque o/a colega não passava a bola, ou porque o/a colega perdia a bola para o outro time. Situações banais eram motivos de sérias confusões.

No início da intervenção, propomos que os times deveriam ser mistos, mas nos frustramos na primeira experiência, pois o pátio da escola, onde aconteciam as aulas de Educação Física, ficou semelhante a um campo de guerra. Diante da situação desistimos da ideia inicial, mas o cenário de violência não mudou, porque os meninos menos habilidosos eram violentados verbalmente todas às vezes que erravam uma jogada.

Sentimos que muito precisa ser feito para mudar minimamente o cenário descrito, mas temos consciência que durante o processo de estágio nos deparamos com várias limitações, dentre elas o pouco tempo que passamos na escola, para pensarmos em medidas efetivas que solucionasse algumas das problemáticas encontradas.

Assim, percebe-se que são muitos os desafios que permeia a realidade da Educação Física escolar, ainda mais porque esse componente não tem a sua legitimidade firmada neste contexto. E quando se fala de esportes, principalmente o futebol, fica nítido que muitas questões que marcam a sua história ainda precisam ser desveladas durante a explanação deste conteúdo na escola, pois a hegemonia dessa manifestação nas aulas de Educação Física, muitas vezes, se dá de forma descontextualizada.

\section{CONSIDERAÇÕES FINAIS}

Ao refletirmos acerca dos limites e dos avanços que permearam a nossa prática pedagógica, podemos concluir que apesar das dificuldades que encontramos no decorrer das nossas intervenções, a experiência nos proporcionou uma série de conhecimentos para o exercício profissional.

As experiências vivenciadas no contexto da sala de aula nos levaram a refletir sobre a necessidade de se pensar em um trabalho docente que valorize a diversidade cultural e que acredite na construção de uma sociedade justa e democrática. 
Ao traçarmos essas discussões acerca da hegemonia do futebol nas aulas de Educação Física, não pretendemos negar essa manifestação corporal, pelo contrário, defendemos que esta temática deve ser problematizada, contextualizada e vivenciada no espaço escolar, lançando luzes sobre as representações que esta manifestação traz consigo.

Nota-se que a violência é um fenômeno que vem alarmando toda a sociedade, e essa violência já "tem marca registrada" no mundo futebolístico, e como o futebol tem lugar de destaque nas aulas de Educação Física, percebe-se que atos violentos estão se tornando cada vez mais frequentes e mais intensos no futebol da escola.

\section{REFERÊNCIAS}

[1] BRITO, F. P. Por mais que não apareçam... mulheres também jogam futebol, 2013. Disponível em: <http://blogueirasfeministas.com/2013/08/por-mais-que-nao-aparecam-mulheres-tambem-jogam-futebol/>. Acesso em: 02 de novembro de 2014 .

[2] ESCUDERO, N. T. G. e NEIRA, M.G. Avaliação da aprendizagem em Educação Física: uma escrita autopoiética. Est. Aval. Educ., São Paulo. 2011.

[3] LIMA, M. S. L. Reflexões sobre o estágio: prática de ensino na formação de professores. Rev. Diálogo Educ., Curitiba, v. 8, n. 23, p. 195-205, jan./abr. 2008.

[4] MORAES, G. H. S. M. de. MORAES, O. M. S. M. de. Futebol e violência: Freud explica? Estud. Pesqui. Psicol., Rio de Janeiro, v. 12, n. 1, p. 145-157, 2012.

[5] NEIRA, M. G.; NUNES, M. L. F. Educação física, currículo e cultura. São Paulo: Phorte, 2009.

[6] NUNES, M. L. F.; RUBIO, K. O(s) currículo(s) da educação física e a constituição da identidade de seus sujeitos. Currículo sem fronteiras, v.8, n.2, pp.55-77, jul/dez 2008

[7] PIMENTA, S. G.; LIMA, M. S. L. Estágio e docência: diferentes concepções. Revista Poíesis, v 3, n. 3 e 4, pp.5-24, $2005 / 2006$.

[8] PIMENTA, S. G. e LIMA, M.S. L. Estágio e Docência. São Paulo: Cortez, 2004. 


\section{Capítulo 10}

Contribuições, desafios e possibilidades da prática profissional do tradutor intérprete de libras do Instituto Federal do Piauí

Joaquina Maria Portela Cunha Melo

Luzia Almeida de Sousa

Tania Maria dos Santos

Delany Ramos de Sousa

Dinalva Clara Monteiro Santos Silva

Resumo: 0 presente artigo traz relatos de experiência do profissional tradutor intérprete de LIBRAS atuando no contexto educacional de sala de aula, no ensino técnico integrado ao médio, no Instituto Federal do Piauí - IFPI, campus Teresina Central. Tem por objetivo apresentar as vivências deste profissional destacando suas contribuições, possibilidades da profissão e as dificuldades enfrentadas neste ambiente, como um sujeito que muitas vezes tem sua função confundida com a de professor. No intuito de valorizar as experiências vivenciadas pelo profissional tradutor intérprete de LIBRAS no exercício de sua função, num primeiro momento, apresenta-se uma abordagem da trajetória histórica deste profissional, com destaque para sua importância em sala de aula como mediador da comunicação entre surdos e ouvintes, garantindo, neste cenário, o cumprimento do decreto de $\mathrm{n}^{0} \mathbf{5} .626$ de 2005. Em seguida, faz-se uma discussão sobre a formação deste com a regulamentação de sua profissão por meio da Lei de $\mathrm{n}$ o 12.319 de 2010. E, por último, apresenta-se uma análise das experiências relatadas por esses profissionais no exercício da sua função, pontuando dificuldades encontradas, contribuições desse trabalho de intérprete tradutor e novas possibilidades para o exercício dessa profissão dentro da Instituição. Para o desenvolvimento da pesquisa os dados foram coletados através de relatos de experiência dos 4 profissionais, tradutores intérpretes de LIBRAS do Instituto Federal do Piauí campus Teresina central. Para fundamentar este trabalho, foram considerados os seguintes autores: QUADROS (2004), SOUZA (2007) LACERDA ( 2014) e GÓES ( 2012), dentre outros.

Palavras-chave: Intérprete, LIBRAS, Vivências, Surdo, Educação 


\section{INTRODUÇÃO}

Atualmente, o intérprete de LIBRAS é um profissional requisitado em muitos ambientes e em eventos variados, pela necessidade legal de garantir o acesso das pessoas surdas às informações que são veiculadas. É nessa perspectiva que se coloca a atividade desse profissional como imprescindível para oferecer acessibilidade para pessoas surdas nas mais diversas situações, principalmente no ambiente escolar.

As pessoas surdas têm como língua materna a Língua Brasileira de Sinais- LIBRAS, diferentemente dos ouvintes que possuem a Língua Portuguesa como sua primeira língua. Nesse contexto, a figura do intérprete entra para estabelecer entre essas duas comunidades, surdos e ouvintes, um entendimento na comunicação.

Segundo Quadros (2004, p.7), o intérprete de língua de sinais é a "pessoa que interpreta de uma dada língua de sinais para outra língua, ou desta outra língua para uma determinada língua de sinais".

O trabalho do intérprete de LIBRAS ganhou relevância com as políticas públicas de inclusão, que permitiram aos surdos maior participação na sociedade, dando-lhes condições de receber informações na sua primeira língua em eventos, reuniões e, principalmente sendo incluídos nas escolas regulares. Além disso, quando a LIBRAS foi reconhecida como língua da comunidade surda pela Lei 10.436/2002, regulamentada pelo decreto 5.626/2005, isso fez com que o intérprete fosse indispensável para promover ao surdo à inclusão onde estiver presente, gerando assim a necessidade da capacitação dos profissionais para atuar em conferências, consultas, concursos e no ambiente educacional, sendo este último foco de discussão mais aprofunda neste trabalho.

Nesse contexto, a abertura de um conceito de educação inclusiva bilíngue inseriu o intérprete no âmbito da sala de aula como um mediador nas relações comunicativas entre alunos surdos, ouvintes e professores, fazendo-o surgir como um novo sujeito dentro do ambiente educacional, mas ainda cercado por muitas dúvidas quanto ao seu verdadeiro papel. Nessa perspectiva de conhecer as experiências da prática desse profissional no contexto da sala de aula é que se inserem os objetivos desta pesquisa.

\section{METODOLOGIA}

O presente trabalho desenvolveu-se a partir de pesquisa qualitativa, uma vez que segundo Gerhardt e Silveira $(2009$, p.31) "a pesquisa qualitativa não se preocupa com representatividade numérica, mas, sim, com o aprofundamento da compreensão de um grupo social, de uma organização, etc".

Assim, para embasar o trabalho foram pesquisadas bibliografias com o intuído de melhor compreender a temática sobre o profissional intérprete, de acordo com Fonseca (2002, p.32) "procurando referências teóricas publicadas com o objetivo de recolher informações ou conhecimentos prévios sobre o problema a respeito do qual se procura a resposta."

Somou-se ao estudo como instrumento de obtenção de informações aplicação de uma única pergunta, a qual foi solicitado ao pesquisado o relato de sua experiência dentro da instituição que serviu como lócus, sendo está uma técnica conforme diz Prodanov e Freitas $(2013$, p. 59) " [...] deverá ser representativa e suficiente para apoiar as conclusões".

\section{RESULTADOS E DISCUSSÕES}

No IFPI, não apenas no campus Teresina Central, é novidade a presença do profissional intérprete de LIBRAS como servidor efetivo, antes existiam apenas tutores. Com a demanda crescente de alunos surdos e a obrigatoriedade da legislação, fez-se necessária a realização de concurso público para contratação deste profissional.

Assim, como atividade recente no campus Teresina Central, os intérpretes têm vivenciado situações diversas que afetam a sua prática e, certamente, têm muito a dizer sobre suas vivências profissionais. Nesse sentido, conhecer as dificuldades desse trabalho e as possibilidades para desenvolvimento dessa profissão dentro do campus dando voz aos profissionais da área através dos seus relatos apresentou-se como uma proposta instigante a partir da qual podem ser traçados novos paradigmas para essa atividade dentro da Instituição. 
Os profissionais, estabelecidos no Campus Teresina Central, tem formação acadêmica na área da educação, especialização em LIBRAS, são tradutores intérpretes de LIBRAS formados pelo CAS e possuem experiência profissional entre três a cinco anos nesta função. Deste modo são profissionais capacitados com prática suficiente na área de interpretação educacional e podem, pois, expressar suas vivências com segurança, principalmente no que diz respeito à sala de aula.

Nesse contexto, apresenta-se o relato de experiência dos tradutores intérpretes de LIBRAS do campus Teresina Central, sujeitos que contribuíram para esta pesquisa destacando suas dificuldades e possibilidades encontradas ao atuar dentro de sala e em outros espaços da instituição.

\begin{tabular}{|c|c|}
\hline $\begin{array}{c}\text { Intérprete } \\
1\end{array}$ & $\begin{array}{l}\text { Já esperava os desafios cotidianos, pois era uma atuação em sala de aula de curso técnico com um grande } \\
\text { número de disciplinas e uma carga horária extensa. Comecei atuar no meio do semestre, o ano letivo e os } \\
\text { conteúdos disciplinares estavam avançados o que dificultou um bom desempenho nas interpretações, } \\
\text { que precisa muitas vezes de uma preparação prévia. } \\
\text { Me deparei com um aluna que apresentava um conhecimento básico em Libras, sendo que a mesma } \\
\text { cursava ensino médio, o que exigiria um conhecimento mais avançado da língua de sinais, então foi } \\
\text { necessário o uso de estratégias como: datilologia, gestos, escrita. O diferencial estava no domínio do } \\
\text { português que esta aluna tem superior aos demais alunos surdos que já tive contato. } \\
\text { Outra dificuldade que encontrei foi em relação ao corpo docente que não sabiam de fato a minha função } \\
\text { em sala de aula, provocando olhares de surpresa, alguns tinham conhecimento da profissão outros não, } \\
\text { algumas vezes fui chamada de tutora, mas a situação foi contornada no momento em que aconteceram } \\
\text { reuniões para apresentações e esclarecimentos sobre a atuação do profissional intérprete. } \\
\text { As mudanças começaram a surgir depois da minha presença como intérprete, a aluna começou a expor } \\
\text { suas opiniões e indagações durante as aulas, passou a ser um sujeito ativo na classe, inclusive na } \\
\text { apresentação de trabalhos, estas mudanças só foram possíveis com a colaboração e interação do } \\
\text { professor e intérprete que estabeleceram contato para esclarecimentos sobre particularidades do seu } \\
\text { aluno surdo, com isso foi conquistado inclusive provas adaptadas de algumas disciplinas e aulas extras, o } \\
\text { que mostrou resultados positivos, contudo nem todas as avaliações seguem a regra. }\end{array}$ \\
\hline $\begin{array}{c}\text { Intérprete } \\
2\end{array}$ & $\begin{array}{l}\text { Eu, Interprete de Libras no Instituto Federal do Piauí, tenho visto um avanço no que tange a inclusão, } \\
\text { mas tenho visto também as dificuldades sentidas por nós, intérpretes, por causa das diferenças de áreas } \\
\text { nos cursos do IFPI, dificultando na sinalização de alguns termos que não possuem sinal e o não } \\
\text { revezamento de intérpretes no atendimento ao surdo em sala de aula, que se torna um pouco cansativo, } \\
\text { principalmente nas disciplinas pedagógicas. } \\
\text { A sinalização em algumas disciplinas se torna dificultosa devido a estes sinais não terem sido } \\
\text { oficializados e escolhidos pelos surdos, por exemplo, um dos surdos que presto atendimento faz o curso } \\
\text { de eletrotécnica e é o primeiro surdo no Piauí a ingressar no curso, este também apresenta muita } \\
\text { dificuldade no português escrito o que dificulta muito. } \\
\text { Por outro lado, percebo que os surdos aqui matriculados tem um excelente desempenho, apesar das } \\
\text { dificuldades que tiveram no ensino fundamental ou médio sem Intérpretes de Libras, avançaram no } \\
\text { processo de aprendizagem e se sentem mais inseridos por causa dos Intérpretes. É também muito } \\
\text { gratificante poder fazer parte desse elo entre o surdo e o Instituto e ver o avanço dessa inserção }\end{array}$ \\
\hline $\begin{array}{c}\text { Intérprete } \\
3\end{array}$ & $\begin{array}{l}\text { Sou intérprete do Instituto Federal campus Teresina Central, não tive muitas dificuldades no que se } \\
\text { refere à aluna surda, pois a mesma tem domínio de LIBRAS e do Português comparando com outros } \\
\text { surdos que já fui intérprete. No inicio alguns professores ficaram surpresos com a minha presença em } \\
\text { sala, mas com o tempo aconteceram algumas reuniões coordenadas pela diretora de ensino com a } \\
\text { presença de todos os intérpretes e muitas questões foram esclarecidas de como proceder com o aluno } \\
\text { surdo em sala de aula, informações que facilitaram as aulas, elaboração de provas e apresentação de } \\
\text { trabalhos. } \\
\text { Um dos grandes desafios desta função no IFPI é que os cursos técnicos integrados ao médio possuem } \\
\text { uma carga horária extensa e não temos outro profissional para revezar, isso gera um grande cansaço } \\
\text { físico e mental, no final da aula estou tão cansada que a qualidade da interpretação não é a mesma, } \\
\text { algumas vezes tenho que parar de sinalizar para descansar e neste período o surdo perde muitas } \\
\text { informações. Também existem algumas dificuldades em relação às disciplinas especificas que não } \\
\text { existem sinais para alguns termos, neste caso combinamos com o surdo sinais informais para usar. } \\
\text { Mesmo com as dificuldades sinto que os professores, não todos são bem abertos a novas informações } \\
\text { sempre que surge uma dúvida perguntam como trabalhar alguns conteúdos, sinto que existe esta } \\
\text { parceria intérprete - professor. Também quando tenho algumas dificuldades em relação ao conteúdo os } \\
\text { professores explicam para que a sinalização seja mais segura facilitando a compreensão da aluna surda. }\end{array}$ \\
\hline
\end{tabular}




\begin{tabular}{|c|l|}
\hline \multirow{5}{*}{$\begin{array}{c}\text { Intérprete } \\
4\end{array}$} & $\begin{array}{l}\text { Estou consolidando minhas experiências de intérprete de Libras no Instituto Federal do Piauí -IFPI, e } \\
\text { percebo algumas diferenças neste ambiente acadêmico, pois apesar do público ser constituído de } \\
\text { surdos e ouvintes, assim como nos demais espaços educacionais que já interpretei, os conteúdos } \\
\text { curriculares do curso, são desafiadores, exigem mais estudos e dedicação, o que envolve processos } \\
\text { cognitivos complexos, bem como demandar grande esforço físico e mental pela quantidade de aulas } \\
\text { ministradas e por atuar sozinha em sala sem possibilidade de revezamento, em alguns momentos } \\
\text { percebo que as interpretações perdem um pouco a qualidade. No que diz respeito à aluna surda } \\
\text { percebo algumas dificuldades em relação ao português escrito, mas consegue expressar - se em Libras, } \\
\text { sem dificuldade, a não ser em algumas disciplinas que está tendo contato agora. }\end{array}$ \\
$\begin{array}{l}\text { A necessidade de um vocabulário amplo e específico acredito se constitua outra dificuldade encontrada } \\
\text { na execução desta função, até porque muitas vezes não temos acesso com antecedência aos conteúdos } \\
\text { a serem trabalhados. Acredito que alguns professores não entendem que precisamos planejar nossas } \\
\text { interpretações, procurar sinais novos, debater com os outros profissionais. Por isso, muitas vezes é } \\
\text { comum os intérpretes serem confundidos com um tutor/professor do aluno surdo ou mesmo da sala de } \\
\text { aula. Porém não senti esta dificuldade uma vez que, comecei a trabalhar no IFPI depois das outras } \\
\text { intérpretes e acredito que elas esclareceram nossa real função na mesma. } \\
\text { o IFPI ao promover a inclusão dos profissionais intérpretes contribui expressivamente com a inclusão } \\
\text { dos surdos aumentando as chances de em um futuro próximo termos ótimos profissionais no mercado } \\
\text { de trabalho. }\end{array}$ \\
\hline
\end{tabular}

Diante de tudo que foi exposto pode-se perceber que os profissionais apresentam em comum algumas dificuldades no diz respeito à carga horária trabalhada dentro de sala de aula, sendo a mesma extensa, poucos profissionais para atender demanda o que não possibilita o revezamento entre os mesmos, a dificuldade nos sinais das disciplinas específicas, pois requer um domínio diferenciado dos conteúdos, o profissional precisa ter um conhecimento prévio dos conteúdos através do acesso aos materiais ministrados em sala antecipadamente, para assim melhorar a qualidade da sua interpretação.

Segundo Quadros (2004, p. 27):

Processa a informação dada na língua fonte e faz escolhas lexicais, estruturais, semânticas e pragmáticas na língua alvo que devem se aproximar o mais apropriadamente possível da informação dada na língua fonte. Assim sendo, o intérprete também precisa ter conhecimento técnico para que suas escolhas sejam apropriadas tecnicamente.

Duas intérpretes apontam como uma de suas dificuldades o português escrito por parte dos alunos surdos que acompanham o que dificulta no desenvolvimento das atividades, pois os alunos conseguem expressarse muito bem de forma sinalizada, mas ao partir para o português produzem, mas com muitas dificuldades. Segundo Goés (2012, p.3), "pessoas surdas mesmo depois de terem passado por longo período de escolarização, apresentam dificuldades no uso da linguagem escrita".

A dificuldade é gerada muitas vezes por falta de uma aprendizagem significativa nas séries iniciais e uma falta de acompanhamento por parte da família, uma vez que algumas famílias tratam a surdez como uma patologia, passível de cura. Dessa forma não utilizam de estratégias específicas no processo de alfabetização, o que gera lacunas na aprendizagem deste sujeito.

Outra dificuldade apontada foi em relação à falta de conhecimento da função do intérprete por parte dos docentes na instituição, mas esta momentaneamente foi contornada, isto porque é de conhecimento de todos a existência da rotatividade de professores nas instituições educacionais, o que pode implicar no retorno de tal situação em um outro momento, bem como pela indiferença de alguns docentes.

0 professor e o intérprete de Libras não podem ser comparados e nem mesmo ter equívocos quanto à função de cada um em sala de aula.

0 professor tem o papel fundamental associado ao ensino e, portanto, completamente inserido no processo interativo social, cultural linguístico. 0 intérprete, por outro lado, é o mediador entre pessoas que não dominam a mesma língua abstendo-se, na medida do possível, de interferir no processo comunicativo. (QUADROS, 2004, p.29 e 30). 
O intérprete e o professor trabalham em parceria, esta relação reforça o que Lacerda $(2014$, p.53) "a relação amistosa entre professor e intérprete, possibilita um diálogo franco sobre acertos e problemas em sala de aula colaborando para melhores condições de ensino aprendizagem aos alunos surdos". Esta parceria é vista como algo significativo neste processo o que reflete no desenvolvimento do aluno surdo dentro do Instituto.

A presença do intérprete de LIBRAS em sala de aula no IFPI possibilitou ao aluno surdo expor suas opiniões e participar de forma efetiva nas diferentes atividades propostas no ambiente escolar, também foi possível ao professor avaliar o nível de aprendizagem de seu aluno e perceber que este é um sujeito ativo no processo de aprendizagem considerando suas especificidades.

Foi possível perceber nos relatos apresentados que a relação com os docentes no instituto foi bem positiva, estes demonstraram interesse pelas informações no que diz respeito a interação com o aluno surdo e em relação ao trabalho do profissional intérprete, este tem autonomia e liberdade ao expor suas sugestões embasadas em experiências e estudos, sugestões estas que visam contribuir para melhoria do trabalho do docente em sala de aula.

Ao fazer uma análise das falas destes profissionais percebe-se que os mesmo apresentam semelhanças ao apontar as dificuldades e possibilidades no exercício de suas funções e que, mesmo com os desafios, procuram por meio destes relatos, discutir e refletir sobre o processo de incluir esta nova demanda de alunos no Instituto Federal do Piauí.

\section{CONCLUSÃO}

É inegável que o intérprete é um personagem novo dentro das escolas, por isso ainda persistem algumas dúvidas sobre suas reais responsabilidades diante do processo de ensino aprendizagem dos surdos e quais os seus limites, pois como sabemos o espaço passa a ser dividido entre dois profissionais, o professor e o intérprete de LIBRAS cada um com suas competências específicas.

No decorrer desta pesquisa é explícito que discutir o papel do intérprete no ambiente escolar é uma questão complexa, pois existem teorias que distinguem o professor do intérprete e mostra que ambos possuem papeis diferentes, mas no cotidiano escolar essa relação é muitas vezes confundida.

É compreensível que realizar o processo de ensino aprendizagem do surdo não é fácil, acentuando-se essa dificuldade quando o professor não tem nenhum conhecimento sobre a surdez, e neste contexto o profissional intérprete de LIBRAS precisa se dispor não em realizar a função do professor, mas contribuir com esclarecimentos sobre alguns aspectos para facilitar tal processo, até mesmo porque o que difere da legislação o docente não foi preparado para atender tal demanda.

Portanto, o Instituto Federal do Piauí ao promover a inserção deste profissional em seu quadro efetivo, valoriza o mesmo e permite que este busque além de uma qualificação, a possibilidade de discussão sobre sua função e desta forma contribua de maneira positiva para a inclusão de fato e de direito do aluno surdo no IFPI. Sendo o intérprete um mediador no processo de ensino e aprendizagem, um profissional que contribui para minimizar as barreiras de comunicação encontradas neste ambiente.

\section{REFERÊNCIAS}

[1] BRASIL. Decreto 5.626 de 22 de dezembro de 2005. Regulamenta a lei 10.436 de 24 de abril de 2002. http://www.planalto.gov.br/ccivil_03/_ato2004-2006/2005/decreto/d5626.htm. Acessada em 24 de junho 2014.

Lei 10.436 de 24 de abril de 2002. Dispõe sobre a Língua Brasileira de Sinais - Libras e dá outras providências. Disponível em :http://www.planalto.gov.br/ccivil_03/leis/2002/110436.htm. Acessado em 24 de junho de 2014.

Lei 12.319 de $1^{\text {o }}$ de setembro de 2010. Regulamenta a profissão de Tradutor e Intérprete da Língua Brasileira de Sinais- LIBRAS. Disponível em: http://www.planalto.gov.br/ccivil_03/_Ato2007-2010/2010/Lei/L12319.htm. Acessado em 26 de junho de 2014.

[2] FONSECA, J. J. S. Metodologia da pesquisa científica. Fortaleza: UEC, 2002. Apostila.

[3] GERHARDT, Tatiana Engel; SILVEIRA, Denise Tolfo (organizadoras). Métodos de Pesquisa. 1a Ed. Porto Alegre: Editora da UFRGS, 2009.

[4] GÓES, Maria C. R de. Linguagem, Surdez e educação. - 4⿳一巛工 Ed. Revista - Campinas, São Paulo : Autores associados, 2012. 
[5] LACERDA, Cristina B. F de. A inclusão de alunos surdos: o que dizem alunos, professores, e intérpretes sobre esta experiência. Cad. Cedes, Campinas, vol.26, n.69, p. 163-184, maio/ago. 2006. Disponível em: Disponível em http://www.cedes.unicamp.br.

Intérprete de libras: em atuação na educação infantil e no ensino fundamental. Ed. Mediação, 6a edição. Porto Alegre 2014.

[6] QUADROS, Ronice. M. O tradutor e intérprete de língua brasileira de sinais e língua portuguesa. Secretaria de Educação Especial; Programa Nacional de Apoio à Educação de Surdos. Brasília: MEC; SEESP, 2004. 12.

[7] PRODANOV, Cleber Cristiano e FREITAS, Ernani Cesar de. Metodologia do trabalho científico: métodos e técnicas da pesquisa e do trabalho acadêmico. 2. ed. Novo Hamburgo: Feevale, 2013.

[8] SOUZA, Regina M. de. O Professor Intérprete de Língua de Sinais em Sala de Aula: Ponto de Partida para se Repensar a Relação Ensino, Sujeito e Linguagem. Campinas, Educação Temática Digital, 2007, p. 154-170. 


\section{Capítulo 11}

Relatos de experiências de leitura e escrita em sala de aula da língua portuguesa - 3ํAno Ensino Médio

\section{Jefferson Fellipe Jahnke}

Resumo: A relevância da leitura merece atenção especial dos educadores. 0 alicerce do ato de ler, precisa ser atraente, ameno, com adoção de livros adequados que forneçam pela correção da linguagem o exemplo de escrever correto. A leitura constitui-se um princípio basilar de comunicação, a vivificar a palavra escrita e a ensejar o intercâmbio de ideias e pensamentos entre países e nações. 0 professor visa, a partir dessa prerrogativa a expansão dos conhecimentos e habilidades intelectuais e da criatividade. Entende-se que 0 aluno do ensino médio deve ser considerado como produtor de textos. Nesta concepção o aluno é ao mesmo tempo, o sujeito do que escreve e lê. 0 movimento da leitura, o trabalho de elaboração de sentidos dá concretude ao texto de acordo com os objetivos da tarefa, plano de organização e a elaboração dos textos. De acordo com Soares (1995), a leitura desenvolve experiências, as quais os alunos interagem com suas próprias vivências. Assim, ao analisar a leitura no início da aula, na tentativa de motivar as atividades diversas observou-se a curiosidade e o interesse à temática proposta do meio ambiente. Nas atividades aplicadas de produções textuais os problemas gramaticais, a não objetividade com o texto, a ortografia, a coerência e coesão são fatores importantes de análise nos textos. 0 referencial linguístico e o aporte da escrita, a formação técnica do ato de ler e escrever. A apresentação gráfica e o desenvolvimento da ampliação do vocabulário, do conhecimento e da cultura. 0 ato da leitura é de suma importância ao aluno e, permite, a organização das ideias à escrita.

Palavras-chave: A prática da leitura e escrita. Ambiente escolar. Prática e resultado. 


\section{INTRODUÇÃO}

Por sua grande importância na existência do indivíduo, a leitura merece atenção especial dos educadores, uma vez que o ato de ler é o alicerce da intelectualidade. Por isso ambiente escolar, especialmente nas aulas de leitura, precisa ser atraente, ameno, com adoção de livros adequados que forneçam, pela correção da linguagem, excelência de mensagens, precisão de vocabulário e exemplo de escrever correto. Outrossim, os professores, apesar de visarem a formação do hábito de leitura e o desenvolvimento do espírito crítico, muitas vezes, não oferecem atividades, nem utilizam recursos que permitam a expansão dos conhecimentos, das habilidades intelectuais e da criatividade.

É importante citar que a leitura constitui-se num princípio basilar de comunicação, a vivificar a palavra escrita e a ensejar o intercâmbio de ideias e pensamentos entre países e nações. A leitura é um veículo mais eficiente para a indagação e a pesquisa, pois permite ao leitor estudar em seu ritmo característico, ampliar seus horizontes culturais dentro de opções próprias. Por sua grande serventia na existência do indivíduo, a leitura merece atenção especial dos educadores, uma vez que o ato de ler é alicerce de intelectualidade, a ação pedagógica há de ser a mais estimulante, para que cada aluno faça dela um processo pessoal de crescimento. Por isso, o ambiente escolar, especialmente nas aulas de leitura, precisa ser atraente, ameno, com adoção de livros adequados que forneçam, pela correção da linguagem, excelência de mensagens, precisão de vocabulário e exemplo de escrever correto. Assim, concomitante ao ato de ler, o aluno pode desenvolver o gosto pela escrita.

Pelos PCN-EM (BRASIL, 1999) é de suma importância que o aluno se torne um produtor de textos, porque é pelo caminho da leitura que o professor observa o funcionamento da língua nos textos de seus alunos e na organização escrita. Assim, percebe-se que o aluno deve percorrer as etapas da leitura, armazenar um referencial lingüístico significativo de ideias e tornar-se capacitado para a produção textual.

Levando em consideração esses aspectos é que surgiu o interesse da confecção desta pesquisa, que consiste em fazer um relato de experiências de leitura e escrita em sala de aula da Língua Portuguesa - 3o Ano Ensino Médio, numa escola da Rede Pública Municipal de Curitiba.

Por sua vez, pretende-se discutir os resultados da turma elencando maneiras de exposição da aprendizagem com a língua falada e escrita no $3^{\circ}$ ano do ensino médio, pois a análise feita dos resultado em nosso país não é satisfatório.

Dessa maneira, o referencial linguístico e o aporte da escrita, torna-se de grande importância na formação desses alunos, o professor engajado, contribui de múltiplas formas desde o ato de ler, na ação do sujeito, como na habilidade de escrever a formatação de como organizar seu texto de forma coesa e coerente.

A preocupação do ensino da leitura é de grande relevância, pois fortalece a formação daqueles que pretendem ou não utilizar-se dessa técnica, pois a leitura fomenta a emancipação e o domínio da língua.

A legislação da educação brasileira, promove em seu ministério a leitura fortalecendo os índices de leitores no Brasil. Com essa intenção, a pesquisa em sala de aula no $3^{\circ}$ ano do ensino médio, se torna necessária para seu incentivo.

O objetivo geral desse relato é o de fazer uma avaliação da prática de leitura e uma análise dos textos efetuados pelos alunos, cujo tema foi "O meio ambiente".

Outros objetivos específicos foram definidos como:

a) mostrar a importância da leitura e escrita segundo alguns teóricos que dissertaram sobre o assunto;

b) analisar o conhecimento dos alunos com relação à ortografia, apresentação gráfica da redação, desenvolvimento das idéias, coesão e coerência dos textos apresentados;

c) propor algumas recomendações aos alunos 


\section{A IMPORTÂNCIA DA LEITURA}

A leitura pode se constituir num prazer, pois oferece evidentes vantagens como ampliação de vocabulário, de conhecimento e de cultura. Lê-se para sonhar, para usufruir o tempo livre, penetrando em outros mundos e épocas, transcendendo, desse modo, à própria individualidade.

O pensar na leitura não é apenas o ato de decodificação da palavra escrita, pois como diz Freire (1981, p. 73) "a leitura do mundo precede a leitura da palavra". Assim, o indivíduo ao ler o mundo, pode ter consciência dos processos que interferem na sua existência como ser social e político. Por isso, a leitura da comunicação impressa só se efetiva e se reproduz quando está ligada ao ambiente em que o homem ou a mulher se sentem sujeitos, atores decisivos para configurar a ação existencial de que participam.

Soares (1995) relata que não basta ir às aulas para garantir pleno êxito nos estudos, mas, é preciso ler, pois quem não sabe ler, não saberá resumir, nem tomar apontamentos e muito menos saberá estudar.

Mostrando que a experiência da leitura pode resultar em aprendizado, em melhores condições para a compreensão, não apenas dos textos, mas dos fatos e fenômenos da própria vida. Maria (2002, p. 24) assim define a leitura:

a leitura é pensamento, pensamento que se constrói sobre a informação visual impressa, pensamento que é alimentado e dirigido pela escrita. 0 ato de construir sentido a partir do texto impresso é por o pensamento, interagindo com o texto, interagindo com o autor do texto. 0 envolvimento emocional do leitor com a experiência da leitura é o mesmo que se pode ter em qualquer tipo de experiência e, da mesma forma, dela extraímos sempre algum aprendizado. A leitura é possibilidade de diálogo para além do tempo e do espaço; é o alargamento do mundo para além dos limites do nosso quarto, mesmo sem sairmos de casa; é a exploração de experiências as mais variadas, quando não as podemos viver realmente.

Dessa maneira, com a leitura o ser humano nunca está sozinho, pois ele pode de cercar de paisagens e pessoas, explorando as experiências mais variadas, dialogar com meios sociais e geográficos muito distantes do cotidiano, dialogar com passados remotos e viver experiências de outros momentos históricos. Em linhas gerais, a leitura tem a facilidade de ser um ponto de apoio para as descobertas dos alunos, o enriquecimento do vocabulário, a interpretação das mensagens, nas quais o aluno, certamente, desenvolverá a sua capacidade de criar e recriar.

Vale ressaltar, que os textos que devem ser trabalhados estão ligados à literatura infanto-juvenil são eles: prosas, poemas, contos, poesias, narrativas, fábulas, com intuito de pensar os comportamentos humanos, assim, incentivando através dos seus limites, a uma prática cotidiana.

\subsection{A LEITURA E A PRÁTICA DA PRODUÇÃO DE TEXTOS NO ENSINO MÉDIO}

Pelos PCN-EM (BRASIL, 1999, p. 139), entende-se que "o aluno do ensino médio deve ser considerado como produtor de textos, aquele que pode ser entendido pelos textos que produz e que o constituem como ser humano". Nesta concepção, o aluno é ao mesmo tempo, sujeito do texto que lê e que escreve. Por isso, o texto deve tornar-se num espaço de interação, interlocução e embate de ideias. Na medida em que as aulas se pautem no desenvolvimento da capacidade interativa do aluno, deixa-se de lado uma noção de Língua visa como um conjunto de conhecimentos externos ao aluno para se ativar preferencialmente um conceito mais amplo, o de linguagem, ao qual estaria subordinado tanto o estudo da Gramática quanto o de Literatura.

Bakthin (1990) explica que o leitor se institui no texto em duas instâncias. A primeira, no nível pragmático, o texto enquanto objeto veiculador de uma mensagem está atento em relação ao seu destinatário, mobilizando estratégias que tornem possível e facilitem a comunicação. A segunda, no nível linguísticosemântico, o texto é uma "potencialidade significativa" que se atualiza no ato da leitura, levado a efeito por um leitor instituído no próprio texto, capaz de reconstruir o universo representado a partir das indicações, pistas gramaticais, que lhe são fornecidas. É o movimento da leitura, o trabalho de elaboração de sentidos que dá concretude ao texto. 
Matêncio (1994) preocupado com as atividades de produção de textos, aponta alguns componentes que julga importantes para isso, como: os objetivos da tarefa, a construção do plano de organização e a elaboração do texto. Esses componentes devem fundamentar-se tanto no conhecimento que o aluno tem sobre o assunto específico que será tópico do texto em questão e das estratégias de elaboração de textos como na compreensão da proposta solicitada.

\subsection{ANÁLISE DAS ATIVIDADES COM OS ALUNOS EM SALA DE AULA}

A atividade proposta junto aos alunos num primeiro momento esteve voltada à prática da leitura. No início das aulas de leitura muitos alunos demonstraram ociosidade e falta de interesse nas aulas. Na tentativa de vencer esse problema, o professor começou a motivar os alunos através de atividades diversas.

Primeiramente, o professor leu vários gêneros, salientando as diferenças e os propósitos dos tipos de escrita. Em seguida, fez-se a leitura de obras diferentes de um mesmo autor, em voz alta e a seguir foi feita uma discussão, o que encorajou os outros alunos a lerem outras obras daquele autor. Após, uma parte de uma determinada leitura foi lida em voz alta para provocar reflexão, e o professor parou num ponto considerado fundamental e os alunos que quisessem descobrir mais devem então, ler o livro. Porém, isso não despertou maior interesse entre os alunos.

Numa fase seguinte, o professor mostrou sua experiência direta com a leitura, a qual incluiu excursões de estudos práticos e demonstrações em sala de aula. As representações de experiências relatadas pelo professor despertou a curiosidade e o interesse dos alunos, que passaram a fazer vários questionamentos: Quem foi o autor dessa obra? Quais seus pontos de vista? O que defendia? Como os fatos aconteciam? Por que os personagens agiam daquela forma? Isso mostrou que o conhecimento prévio dos alunos fosse ativado e eles demonstraram um entendimento dos conceitos apresentados e passaram a formar grupos de discussões, o que foi muito significativo, pois eles estão aprendendo uns com os outros, enquanto oferecem, apoiam ou refutam ideias. A partir daí, o professor incentivou os alunos a fazerem pequenos textos, como anúncios, bilhetes, entre outros. Muitos alunos ficaram entusiasmados com a tarefa e a produção de textos foi significativa.

0 uso de textos de diversos gêneros deu certo e despertou nos alunos maior motivação para as aulas. Houve reflexão acerca de elementos gramaticais encontrados e elementos textuais. Também foram abordados alguns assuntos sobre literatura contemporânea, figuras de linguagem, modalidade oral e modalidade escrita.

O exercício de redação compreendeu a elaboração de uma redação com o tema "O Meio Ambiente". No princípio os alunos mostraram-se temerosos. Era necessário lidar com cuidado com eles e o professor estava muito atento. Durante os encontros anteriores com os alunos, eles já haviam aprendido as principais fases do desenvolvimento da elaboração de uma redação. Dentre os itens trabalhados, os alunos aprenderam as funções da linguagem, texto literário e não-literário, os gêneros textuais, o novo acordo ortográfico, ortografia, casos de gramática textual.

Foram utilizados os livros didáticos, textos diversos e até recursos da informática como alguns vídeos do youtube. Após o exercício de redação, o professor começou a analisar os textos recebidos e começou a tecer algumas considerações a respeito. Em primeiro lugar, constatou-se que a maioria dos alunos não sabe lidar adequadamente com suas ideias, o que é um dado preocupante, uma vez que toda a estrutura dissertativa dos textos que o aluno apresenta ficam prejudicadas. Possivelmente, essa condição vai prejudicar o aluno quando ele tiver que prestar vestibular.

Também constatou-se que a maioria dos alunos não sabe expor a ideia principal no decorrer do texto, embora alguns poucos o fazem. Os alunos não explicitam suas ideias e não utilizam outras informações e nem sabem ilustrar um texto. Além disso, eles não sabem estruturar os parágrafos que foi o que se observou com a maioria das redações. Houve desvio do assunto, parágrafos curtos ou alongados demais, repetição de termos, falta de conetivos, ausência de coesão e coerência.

Dessa maneira, a parte gramatical da análise dos textos de sala, ficaram comprometidas, pois a maioria dos alunos cometeram erros graves. Em conversas com outros professores, percebeu-se que a correção linguística é um dos componentes mais polêmicos quando os professores vão avaliar as redações. 
Desse modo, os alunos mostraram que não sabem se comunicar, não tem uma expressão clara de seu pensamento, nem sabem utilizar os recursos gramaticais correntemente para que os leitores de seus textos possam avaliá-lo de forma satisfatória.

Outro item que chamou a atenção foi a apresentação gráfica dos trabalhos que se mostrou sofrível. Desse modo, os alunos precisam ser orientados sobre os prejuízos de uma má disposição de suas ideias no papel, em termos de sua competência comunicativa. Dessa maneira, os alunos concluíram a sua redação, mostrando também, que tem pouca percepção comunicativa.

\section{CONSIDERAÇÕES FINAIS}

As atividades junto aos alunos demonstraram algumas particularidades. Num primeiro momento, concluiu-se que a leitura é um requisito preponderante no processo de desenvolvimento e está presente em todos os setores da atividade humana. A leitura é uma forma de comunicação, pois através dela, o leitor interage com o autor e cria um novo contexto de ideais, adquire novos conhecimentos e possibilita acompanhar as mutações de seu tempo. Saber ler é tarefa complexa que ultrapassa o simples reconhecimento de palavras. É necessário compreender o sentido do texto e racionar a partir das informações recebidas, interpretando o que foi lido. Consequentemente, a leitura conduz à escrita, leva à informação, desenvolve o raciocínio, as habilidades de dedução, pode ampliar a cultura, o vocabulário, a criatividade e a capacidade de se comunicar.

Os pais deverão ser envolvidos nos programas de leitura, pois não se pode dissociá-los da vida diária da criança. É necessário que a atuação escolar seja altamente motivadora e continuada na família.

Os alunos deverão ser encorajados a lerem mais, adotando, inclusive, a leitura como diversão, que conduz à espontaneidade e ao desejo pessoal de buscar novos livros. Só desse modo, o ato de ler pode ultrapassar as paredes da escola e se converter verdadeiramente num hábito, garantindo um bom nível de educação. 0 cuidado com a literatura do jovem é tarefa social de relevo, uma vez que está aí a base do conhecimento e do desenvolvimento de suas potencialidades. Em linhas geras, é preciso recuperar o significado da leitura e escrita no meio escolar, transformando as condições de sua realização. Outrossim, a possibilidade de desenvolver interesses e atitudes em relação à leitura pode ser aumentada quando os professores compartilham seu amor pela leitura e dão aos alunos a oportunidade de desfrutarem os materiais impressos em um contexto mais amplo, o qual deve levar em consideração as condições essenciais para a aprendizagem.

Outrossim, o aluno deve ser orientado em sua habilidade de reconhecer, relacionar e selecionar dados não apenas quanto ao seu conhecimento de mundo, mas também sobre a própria atividade de escrita. É necessário tornar o leitor crítico, capaz de discernir intenções e assumir atitudes ante o texto com independência.

Cabe ao professor a tarefa de monitorar e assessorar seus alunos, segundo a dificuldade específica que eles tenham nas diferentes etapas da leitura e produção de textos.

A partir dessas considerações, foi possível relatar os resultados obtidos com os alunos referentes à confecção da redação sobre "O meio ambiente". Os alunos apresentaram falhas quanto à produção de textos, como a falta de organização das ideias, dificuldades em perceber a variação dos assuntos, parágrafos mal construídos, erros gramaticais, uso exagerado de gírias. A apresentação gráfica também foi muito precária. 0 que mais chamou a atenção foi que a maioria dos alunos não sabe lidar adequadamente com suas ideias, o que é um dado preocupante, uma vez que toda a estrutura dissertativa fica prejudicada. Como se observou, os erros dos alunos se multiplicam: partem da ineficiência dos mesmos em expor suas ideias e nem a ideia principal, o que fatalmente conduz aos parágrafos mal estruturas.

Levando em consideração esses resultados foi possível apresentar algumas recomendações. Num primeiro momento, é preciso que a ação da escola seja total no sentido de bem orientar o ensino da leitura, envolvendo todo o corpo docente. Há de se mostrar aos professores a necessidade de conhecer e usar novas metodologias de leitura, para garantir o bom nível da aprendizagem. É importante fazer sentir a cada professor a importância de sua atuação, como incentivador do gosto de ler. Sua ação deverá se estender também aos professores de outras disciplinas, para que estes passem a ser também, professores de leitura. Neste sentido, cada elemento da escola deve ser entendido como um colaborador em potencial e seu desempenho positivo é muito válido. 
O agente educacional tem grande relevância na formação dos estudantes, ademais, professores de outras disciplinas ao engajar-se de maneira eficaz, contribuirá no fomento e, incentivo, na leitura desses alunos.

A hegemonia do saber na escola parte do profissional, que forma e com a contribuição através de projetos, eventos, planos de estudo, a escola com a comunidade escolar, fortalece a proposta da leitura e escrita de qualidade para esses alunos.

Dessa maneira, a figura do professor nessa prática em sala, demonstra que é possível dialogar com os alunos. 0 interesse inicia pela ação do professor, como agente responsável na escola, não somente na disciplina de língua portuguesa, mas em todas as matérias, a interdisciplinaridade deve ser pedagogicamente gerenciada, para que não haja falhas no processo de ensino aprendizagem.

Ao entender esse estudo, conclui-se que para ter um bom trabalho em sala de aula, o docente, precisa incentivar literaturas clássicas, sobretudo, as atuais, porque além de ajudar no despertar de suas ideias, torna-os agentes de sua própria história.

\section{REFERÊNCIAS}

[1] BAKTHIN, N. Marxismo e filosofia da linguagem. São Paulo: Hucitec, 1990.

[2] BRASIL. Ministério da Educação, Secretaria de Educação Média e Tecnológica. Parâmetros curriculares nacionais: ensino médio. Ministério da Educação, Secretaria de Educação Média e tecnológica. Brasília: Ministério da Educação, 1999.

[3] FREIRE, P. Conferência de abertura do III Congresso de Leitura do Brasil. Campinas: Unicamp, 1981.

[4] MARIA, Luzia de. Leitura \& Colheita: livros, leitura e formação de leitores. Petrópolis, RJ: Vozes, 2002.

[5] MATÊNCIO, M.de L.M. Leitura, produção de textos e escola. Campinas/SP: Contexto, 1994.

[6] SOARES, Maria do Carmo. Redação de trabalhos científicos. São Paulo: Cabral, 1995. 


\section{Capítulo 12}

Letramento digital e ensino: Novas relações dialógicas e aprendizagens

\section{Maria de Lourdes Rossi Remenche \\ Ana Paula Pinheiro da Silveira}

Resumo: Buscou-se neste artigo refletir sobre o letramento digital e a forma como tal prática vem sendo mobilizada nos documentos parametrizadores da educação básica ao longo dos últimos anos. Para tanto, ancorou-se a reflexão inicial nos estudos sobre Letramentos (STREET, 1984 e 2006) para, na sequência, discutir-se os estudos do Círculo de Bakhtin. 


\section{APRESENTAÇ̃̃O}

A contemporaneidade é marcada por deslocamentos na maneira de ler, produzir e fazer circular informações na sociedade. De acordo com Kenski (2003), para além da caracterização das tecnologias como um mero suporte, é preciso observar que elas alteram sensivelmente a maneira de as pessoas interagirem, pensarem, relacionarem-se umas com as outras e modificam também a forma de construir o conhecimento. Ou seja, "criam uma nova cultura e um novo modelo de sociedade" (KENSKI, 2003, p. 24).

Para Souza, Corti e Mendonça (2012), isso se deve as mudanças nos modos de vida e nas formas como as pessoas interagem nos diferentes espaços, especialmente os virtuais. Essas mudanças impactam as práticas de letramento e produzem novos gêneros discursivos ${ }^{2}$ a partir dos já existentes.

Tais produções e deslocamentos evidenciam que os usos linguísticos são situados e constituem-se em práticas sociais, desenvolvidas ao longo do tempo e em diferentes culturas, servindo de base para a configuração, relativamente estável, dos gêneros discursivos. Nessa perspectiva, entendemos que os letramentos são situados na história e no tempo, acompanham as mudanças dos diferentes contextos tecnológico, social, político, econômico ou cultural.

Os estudos sobre letramento implicam movimentos dinâmicos de inserção e participação nas práticas sociais e culturais de escrita e de leitura. Assim, ao discutirmos os novos letramentos, precisamos atentar para o espaço ocupado pelas diferentes modalidades de interação ou de produção de sentido e de conhecimento.

O uso de novas formas de representação e de recursos tecnológicos produz impactos na vida social, nas formas de interação e no processo de ensino-aprendizagem. Nessa linha de reflexão, Remenche e Silveira (2017) argumentam que precisamos reafirmar a importância do diverso e do diferente como elementos fundamentais à produção cultural contemporânea e a necessidade de investirmos, cada vez mais, na formação de leitores capazes de mobilizar novas formas de representação de sentido disponíveis na cibercultura.

Considerando essa questão, buscamos neste artigo refletir sobre o letramento digital e a forma como tal prática vem sendo mobilizada nos documentos parametrizadores da educação básica ao longo dos últimos anos. Para tanto, ancoramos nossa reflexão inicial nos estudos sobre Letramentos (STREET, 1984 e 2006) para, na sequência, discutirmos os estudos do Círculo de Bakhtin. As reflexões sobre letramento digital e ensino (XAVIER, 2002; BARTON e HAMILTON, 2008) direcionam nossa reflexão para algumas considerações finais.

\section{OS ESTUDOS SOBRE OS LETRAMENTOS}

Passadas algumas décadas em que se mencionou pela primeira vez a palavra letramento em uma obra brasileira $^{3}$, esse conceito vem balizando estudos na área do ensino de Língua Portuguesa, com a compreensão de que esse fenômeno está intimamente ligado ao uso da escrita em práticas sociais e em contextos específicos (STREET, 1984). Nesse sentido, a escola é vista como uma das agências de letramento presentes na sociedade, responsável por desenvolver o letramento dito "dominante" e que confirma as relações de hierarquia, autoridade e controle.

Ainda na década de 1980 e 1990, os trabalhos de Street (1984) e Besnier e Street (1994) interrogaram-se sobre a dicotomia do modelo autônomo, compreendido como um conjunto de habilidades a serem aprendidas para o uso da escrita e da leitura, e do modelo ideológico, que se contrapunha a primeira perspectiva, reconhecendo a importância de se conceber o termo letramento tendo em vista as relações de poder e os fatores ideológicos que podem perpassá-lo. Nessa perspectiva, o aprendizado da escrita e da leitura não são entendidos como uma habilidade técnica e tampouco neutra, uma vez que está inserido em contexto sociocultural, imbuído de princípios epistemológicos, enraizado em concepções de identidade e de práticas sociais dos sujeitos.

\footnotetext{
2 Assumimos a concepção de Bakhtin (1992) e consideramos os gêneros discursivos tipos relativamente estáveis de enunciados, marcados sócio-historicamente e caracterizados pelo conteúdo temático, estilo e construção composicional.

${ }^{3}$ A obra de Mary Kato em 1986.
} 
Em obra mais recente, Street (2014) propôs um debate acerca do papel do letramento e da educação, explicitando o papel da escola na homogeneização do letramento, dado que o da norma padrão é por vezes o único letramento reconhecido. Na visão desse estudioso, isso acontece porque não fica clara a relação entre práticas e eventos de letramentos. No caso dos eventos de letramento, ele chama a atenção para o aspecto ideológico que diz respeito a "todo tipo de convenções que as pessoas interiorizam - todos sabemos o quanto são estritamente controladas as convenções nos eventos de letramento cotidianos como encontros com a burocracia, seminários ou reuniões" (STREET, 2014, p. 146). Desse modo, alguns modelos de letramento acabam se tornando tradições culturais, e por isso denominados como eventos. Já a prática de letramento diz respeito "a concepções do processo de leitura e escrita que as pessoas sustêm quando engajadas no evento" (STREET, 2014, p. 46).

Street (2014) esclarece ainda que, ao propor programas e desenvolver currículo, é preciso fazê-lo de forma socialmente consciente, o que implica evitar o letramento autônomo e disseminar a multiplicidade de práticas letradas. Ao defender uma visão mais englobante e estreitamente ligada às práticas sociais, 0 pesquisador evidencia a necessidade de distanciamento das práticas disseminadas no passado, marcadas por um letramento burocratizante, formal, funcional, e não representativo das práticas sociais presentes na sociedade. Nesse sentido, Barton (1998) argumenta que o letramento é mais do que um conjunto de habilidades intelectuais, pois se constitui em prática cultural e sócio-historicamente estabelecida, que promove a participação efetiva dos sujeitos nos diferentes contextos sociais.

Nessa reflexão, recupera-se o termo multiletramento cunhado pelo Grupo de Nova Londres (GNL), no manifesto publicado em 1990, A Pedagogy of Multiliteracies - Designing Social Futures (Uma Pedagogia dos multiletramentos - desenhando futuros sociais), para o qual o conceito remete à multiplicidade de linguagem, uma vez que a produção dos gêneros multimodais envolve diferentes linguagens, mídias e semioses, bem como à pluralidade cultural, resultado de uma sociedade sempre mais multiétnica e multifacetada (COPE; KALANTZIS, 2009).

Os estudos de Street (2014) enfatizam sobretudo a visão da multiplicidade cultural, presente na sociedade, como já defendia Lemke (2010, p. 458) ao afirmar que os "Letramentos são sempre sociais: nós os aprendemos pela participação em relações sociais; suas formas convencionais desenvolveram-se historicamente em sociedades particulares". Em consonância com Street (2014), compreendemos que as práticas de letramento acontecem em variados contextos sociais, incluindo a escola e as diversas agências de letramento que promovem diferentes letramentos, assim como também possibilitam a interferência em novas práticas de letramento em um movimento contínuo de produção de sentido e ampliação de visão de mundo/repertório cultural.

É preciso considerar, portanto, que, na sociedade atual, as práticas de escrita e leitura se realizam em uma variedade de meios e que o letramento deve incluir também os modos de produção e recepção de textos multimodais, que hibridizam diferentes semioses e que vão requerer um conhecimento sobre leitura de imagem, de paleta de cores, de textura, de enquadramento, bem como de edição e de remixagem.

Somam-se a isso as mudanças instauradas pelas novas tecnologias digitais que enfatizam o papel mediador do professor e compreendem a aprendizagem como um conjunto de atividades sociais, cognitivas, de interação, que ocorre por meio da participação efetiva do sujeito aprendente. Tal perspectiva mobiliza diferentes metodologias de ensino e que tem levado alguns estudiosos a nomear a metodologia com o adjetivo "ativa". Embora esse conceito esteja em voga na atualidade e venha sendo incorporado como metodologia em muitas escolas, ele não é totalmente novo e não se restringe ao uso das tecnologias. No Brasil, por exemplo, ainda em 1997, quando Paulo Freire ${ }^{4}$ escreveu a sua última obra, Pedagogia da Indignação, apresentou um método para aprender de forma ativa: "As crianças precisam crescer no exercício desta capacidade de pensar, de indagar-se e de indagar, de duvidar, de experimentar hipóteses de ação, de programar e de não apenas seguir os programas a elas, mais do que propostos, impostos. (FREIRE, 2000, p. 26).

Na esteira de Freire, muitos educadores começaram a compreender a necessidade de um método que colocasse o aluno no centro do processo de aprendizagem. Isso em um primeiro momento pareceu estar muito mais próximo de uma educação libertadora - tão questionada nos tempos atuais - do que de uma exigência trazida pelas novas descobertas da Neurociência, das Tecnologias Digitais da Informação e Comunicação, doravante TDIC, e, portanto, de um novo modelo para conceber a aprendizagem.

\footnotetext{
4 Paulo Freire faleceu em 2 de maio de 1997 antes de concluir a escrita de Pedagogia da Indignação, publicação póstuma no ano de 2000.
} 
Nas pesquisas que desenvolvemos na área dos multiletramentos, temos pensado as metodologias ativas e o sujeito proativo a partir de quatro dimensões, assumidas pelo GNL: usuário funcional; criador de sentidos; analista crítico; transformador, traduzidos em quatro objetivos operacionalizáveis do ponto de vista pedagógico: experimentar, conceituar, analisar e aplicar. (COPE; KALANTZIS, 2015).

Ser um usuário funcional está estreitamente ligado à experimentação, envolve a reflexão sobre as próprias experiências e implica provar, testar, imergir-se em situações novas e, a partir delas, agregar conhecimentos. Ser um criador de sentidos está relacionado à conceituação, à capacidade que o homem desenvolve para pensar, analisar, generalizar elementos do mundo real. Ser um analista crítico requer estabelecer relações funcionais de causa e efeito sobre os conceitos científicos apreendidos e atribuir juízo de valor, por meio de uma avaliação crítica. A prática transformadora abarca a intervenção no mundo real de modo inovador e criativo

Em síntese, a proatividade requerida na sociedade atual demanda que o currículo explorar mobilize estratégias para contribuir com a formação de um usuário funcional, com competência técnica e possa, de modo crítico, elaborar conhecimentos, a partir do estudado/aprendido, e possa contribuir para transformar/ressignificar a sociedade.

\section{A PERSPECTIVA DIALÓGICA NAS PRÁTICAS DE LINGUAGEM}

Compreender a linguagem como prática social que permeia as relações intersubjetivas contribui não só para entendermos as diferentes interações sociais nos variados domínios comunicacionais, mas também possibilita um território fértil para investigar as relações que se constituem entre os sujeitos ao comunicar-se, interagir com outros sujeitos, ideias e culturas.

Embora a concepção dialógica, elaborada pelas discussões teóricas do Círculo de Bakhtin, tenha se concentrado nos estudos sobre a linguagem, sua amplitude extrapola os estudos da língua devido a sua densa dimensão filosófica. Na perspectiva dialógica, a concepção de linguagem desloca-se da formalidade dos estudos linguísticos, que abordavam a língua como sistema abstrato de formas ou como produção individual da mente do falante. Esse distanciamento ocorre porque o dialogismo mobiliza a construção e produção de sentidos pautados nas relações discursivas construídas por sujeitos em situações reais de comunicação.

Para Volóchinov (2017), a linguagem percorre os usos linguísticos, pois se materializa em enunciados constituídos tanto pela palavra escrita, quanto pela fala ou por imagens. Nessa dinâmica, o enunciado ganha sentido e se torna real na interação, pois

“A realidade efetiva da linguagem não é o enunciado monológico isolado, tampouco o ato psicofisiológico de sua realização, mas o acontecimento social da interação discursiva que ocorre por meio de um ou de vários enunciados. Desse modo, a interação discursiva é a realidade fundamental da língua. (VOLÓCHINOV, 2017, p. 218 - 219)

Assim, a essência da língua centra-se na interação discursiva, no diálogo, em enunciados concretos materializados nos usos linguísticos, afinal "A língua é um processo ininterrupto de formação, realizado por meio da interação socio discursiva dos falantes” (VOLÓCHINOV, 2017, p. 224).

Nessa concepção, os estudiosos do Círculo propõem que a realidade da língua é a da interação discursiva, pois a condição social de uso permeia a seleção das formas linguísticas. Desse modo, os sujeitos, ao produzirem um enunciado, estão inseridos em contextos socioideológicos estabelecidos, e os usos linguísticos são afetados pela situação efetiva de uso e pelos valores ideológicos. Sobre esses aspectos, Bakhtin esclarece que

“(...)a língua como concretude socioideológica viva, como opinião heterodiscursiva [diversidade de discurso] situa-se, para a consciência individual, na fronteira entre o que é seu e o que é do outro. A palavra de uma língua é uma palavra semialheia; só se torna palavra quando o falante a satura de intenção, de seu acento, assume o domínio da palavra, fá-la comungar em sua aspiração semântica e expressiva. Até este momento de apropriação, a palavra não está numa língua neutra e impessoal (pois não é do dicionário que o falante tira a palavra!), mas em lábios alheios, em contextos alheios, a serviço de intenções alheias: é daí que deve ser tomada e tornada sua". (BAKHTIN, 2015, p. 69). 
Os significados, na perspectiva dialógica, são co-construídos nas interações, e a linguagem vai além da concepção representacionista, assumindo a função de construir, semanticamente, a realidade nas diferentes situações sociais, ou seja, a linguagem está repleta de intenções de outros sujeitos. Brait (2016, p. 10), nesse sentido, argumenta que a perspectiva bakhtiniana "diz respeito a uma concepção de linguagem, de construção e produção de sentidos necessariamente apoiadas nas relações discursivas empreendidas por sujeitos historicamente situados". Para a pesquisadora, o Círculo defende que, ao enunciarem, os sujeitos não se apropriam das formas pré-definidas da língua de modo isolado das relações sociais, pois, embora o uso da língua tenha como base um sistema, o sujeito vai muito além em virtude de sua historicidade que é colocada em jogo na interação verbal.

Nessa linha, depreendemos que a situacionalidade é a base para a construção de sentidos na língua em uso, assim como a concepção que o discurso tem do objeto é dialógica (BAKHTIN, 1998[1975], ou seja, todo discurso nasce no diálogo com sua réplica viva, é internamente dialogizado, heterogêneo e articula inúmeras vozes sociais, pois os sujeitos fazem escolhas e manipulam o sistema, considerando seus propósitos comunicativos e as condições de produção. Nesse sentido, Bakhtin afirma que

A relação dialógica com a palavra do outro no objeto e com a palavra do outro na resposta antecipável do ouvinte, sendo, em essência, diferentes e gerando na palavra efeitos estilísticos diferentes podem, não obstante, entrelaçar-se de modo muito estreito, tornando-se quase indissolúveis para análise estilística. (2015, p. 56)

A comunicação, desse modo, vincula-se à interação, assim como a dialogicidade interna do discurso constitui os campos da vida da palavra de forma variada em um movimento em que "a comunicação verbal entrelaça-se inextricavelmente aos outros tipos de comunicação e cresce com eles sobre o terreno comum da situação de produção." (VOLOCHÍNOV, 2013, p. 128).

Dessa maneira, a essência da linguagem é mediar as relações entre os sujeitos e suas relações com o mundo, o que faz com que a enunciação se torne produto da interação entre duas partes, mesmo em situações virtuais. 0 diálogo, nessa perspectiva, constitui-se em uma das formas de interação, desde que entendamos a palavra diálogo em um sentido mais amplo que envolve qualquer tipo de comunicação. Como meio para se compreender o outro e a si mesmo, o diálogo é fundamental na interação discursiva. A palavra, base da enunciação, sempre é orientada para um interlocutor, pois ela

em sua essência é um ato bilateral. Ela é determinada tanto por aquele de quem ela procede quanto por aquele para quem se dirige. Enquanto palavra, ela é justamente o produto das inter-relações do falante com o ouvinte. Toda palavra serve de expressão ao "um" em relação ao "outro". Na palavra, eu dou forma a mim mesmo do ponto de vista do outro e, por fim, da perspectiva da minha coletividade. A palavra é uma ponte que liga o eu ao outro. Ela apoia uma das extremidades em mim e a outra no interlocutor. A palavra é o território comum entre o falante e o interlocutor. (VOLÓCHINOV, 2017, p. 205)

$\mathrm{Na}$ interação, por meio da palavra, os interlocutores, são tomados como sujeitos com experiência e conhecimento de mundo. Assim, a orientação da palavra volta-se para quem é o interlocutor, sua posição social, laços sociais, entre outros aspectos. A perspectiva dialógica da linguagem, desse modo, compreende que a relação do sujeito com o mundo não é direta, mas atravessada por valores materializados semioticamente. Isso significa que não há um mundo que se dá a conhecer, mas versões do mundo que são refratadas valorativamente nos signos.

Ao deslocarmos essas reflexões para o espaço-tempo educacional, verificamos que as formas e os tipos de interação estão intrinsicamente ligados às condições concretas em que se realizam. Pesquisadores da área de ensino de Língua Portuguesa, como Geraldi (1999) e Rojo (2013), dentre outros, exploram a concepção dialógica da linguagem ao discutir o processo de ensino-aprendizagem e mobilizar conceitos fundamentais relacionados à enunciação, ao papel semiótico, axiológico e ideológico da linguagem na construção de subjetividades, e à produção cultural da sociedade.

Nessa concepção, a interação nas práticas sociais de comunicação é fundamental à construção do conhecimento, especialmente na sociedade contemporânea, marcada por transformações e pelos usos de diferentes linguagens e tecnologias. Os pressupostos teóricos que sustentam a perspectiva dialógica assumem o sujeito ativo que constrói e é construído no texto em uma dinâmica que considera o lugar de interação e produção de conhecimento, assim como o de constituição dos sujeitos. 


\section{LETRAMENTO DIGITAL E ENSINO: 0 QUE DIZEM OS DOCUMENTOS?}

O letramento digital demanda habilidades que extrapolam o uso de recursos digitais com desenvoltura, vai além e possibilita aos estudantes reelaborar seu modo de viver e interagir, bem como realizar novas formas de agir no/sobre o mundo, que se revelam em diferentes interações e modos de materializar o verbal e o verbo-viso-sonoro. Em outras palavras, o letramento digital possibilita maior autonomia para desenvolver as práticas sociais de leitura e de escrita, que suscitam diferentes estratégias e metodologias pedagógicas nas quais os estudantes assumem papel ativo no processo de ensino-aprendizagem. Nessa linha, Barton e Hamilton (1998) chamam a atenção para os vários tipos de letramento:

Letramento não é o mesmo em todos os contextos; ao contrário, há diferentes Letramentos. A noção de diferentes letramentos tem vários sentidos: por exemplo, práticas que envolvem variadas mídias e sistemas simbólicos, tais como um filme ou computador, podem ser considerados diferentes letramentos, como letramento fílmico e letramento computacional. (BARTON, HAMILTON, 1998, p. 9)

Ao analisarmos as práticas de leitura e escrita que circulam na cibercultura, verificamos que são mobilizadas outras formas de ler e escrever os sistemas de representação, sejam eles verbais ou verboviso-sonoros. Tal constatação remete-nos às novas formas de produção, configuração e circulação de textos em meio digital que estão ligados aos multiletramentos, pois se verifica o crescente uso de tecnologias e mecanismos de produção, reprodução e difusão de escrita, desvelando que os processos de letramento envolvem práticas sociais de leitura e escrita em um contínuo de ampliação de significados e de comunicação.

Xavier (2013) argumenta que a revolução digital e suas tecnologias parecem produzir um novo modo de enunciação com uma nova organização dos signos verbo-viso-sonoros que, integrados na tela do computador, fundam o modo de enunciação digital. Esses diferentes textos apresentam novos desafios aos letramentos e às teorias, devido à multiplicidade de linguagens, semioses e mídias envolvidas na produção de sentido para os textos multimodais, além da diversidade cultural trazida pelos sujeitos leitores/produtores na produção de significados.

Ainda sob a mesma perspectiva Coscarelli (2009), afirma que as TDIC promoveram um modo diverso de ler/produzir textos, já que, em meio digital, é possível incluir ou excluir imagem e som, e isso vai exigir "saber lidar com a multimodalidade tanto como leitor quanto como autor" (COSCARELLI, 2009, p. 552). As novas habilidades que os leitores precisam desenvolver, haja vista que os novos gêneros discursivos criados, envolvem a linguagem visual e/ou sincrética, necessária à compreensão tanto do texto impresso, quanto digital. Sobre esse argumento, Daley (2010, p. 488) alega que:

Para ler ou escrever a linguagem da mídia e para entender como ela cria significado em contextos específicos, é preciso algum conhecimento de composição em frames, paleta de cor, técnicas de edição, relação entre som e imagem, assim como a mobilização de convenções narrativas e de gênero, e ainda o contexto de signos e imagens, o som como um veículo do significado, e os efeitos da tipografia. Princípios como direção de tela, enquadramento de objetos, escolhas de cores, formatação, cortes e dissoluções [dissolves], todos juntos fazem muito mais do que uma comunicação visual esteticamente agradável. Esses elementos são estratégicos para a construção do significado, assim como advérbios, adjetivos, parágrafos, orações, analogias e metáforas o são para textos.

Na mesma linha, Buckingham (2010) reconhece que o letramento digital vai envolver questões funcionais de aprendizagem de navegação como, por exemplo, localizar informações na web, usar recursos de busca, mas, sobretudo, saber olhar para a grande quantidade de informação presente na internet de forma crítica, o que irá demandar questionamentos sobre essa geração de informação, pois é preciso entender "os interesses de seus produtores e as formas como ela representa o mundo, compreendendo como estes desenvolvimentos tecnológicos estão relacionados a forças sociais, políticas e econômicas mais amplas (BUCKINGHAM, 2010, p. 49)

A problematização levantada por Buckingham (2010) já estava presente nos documentos que se propunham a elaborar metas e estratégias para o ensino, conforme se observa no texto dos Parâmetros Curriculares Nacionais de Língua Portuguesa(PCNs) para os 3o e 4o ciclos (BRASIL, 1998), ao definirem os objetivos para o Ensino Fundamental: 
[...] utilizar as diferentes linguagens verbal, musical, matemática, gráfica, plástica e corporal como meio para produzir, expressar e comunicar suas idéias, interpretar e usufruir das produções culturais, em contextos públicos e privados, atendendo a diferentes intenções e situações de comunicação (BRASIL, 1998, p. 7-8).

Os PCN (BRASIL, 1998), ao tratarem das Tecnologias da Informação e Língua Portuguesa, explicitam a necessidade do uso das tecnologias digitais, não só como recurso didático, mas como instituidoras de práticas de letramento. Além disso, apresentaram o uso do computador como um editor de texto, uma alternativa para a reescrita textual e para o controle da ortografia, bem como sugerem aplicativos que favorecem o uso de layout de textos impressos de circulação social e a possibilidade de inserção de tabelas, gráficos, imagens e sons. 0 texto defendia, ainda, que o uso da internet pode favorecer a interação em situações reais de escrita e de leitura:

Por combinar diferentes linguagens e atividades multidisciplinares, favorecem a construção de uma representação não-linear do conhecimento, permitindo que cada um, segundo seu ritmo e interesse, possa dirigir sua aprendizagem: buscando informação complementar, selecionando em um texto uma ligação em outro documento, por uma palavra ou expressão; buscando representações em outras linguagens, imagem, som, animação, com as quais pode interagir (BRASIL, 1998, p. 90-91).

No âmbito do Estado do Paraná, a análise das Diretrizes Curriculares da Educação Básica (PARANÁ, 2008) permite-nos afirmar que o documento já definia o texto como um ato dialógico, partindo da concepção bakhtiniana, que concebe a linguagem como interação verbal, na qual o homem constitui-se nas relações que estabelece com o outro, por meio das interações verbais que se dão nas diferentes esferas sociais. Assim, o ser humano produz textos, sentidos, como resultado de sua inserção em um contexto histórico, cultural, social, "produto da criação ideológica ou de uma enunciação, com tudo que está aí subentendido" (BARROS, 1997, p. 28).

O documento indica a necessidade do trabalho com o suporte digital, seja na sua apresentação gráfica, a partir do uso de citações coloridas e em 3D, imagem da capa e a repetição de recortes dessas mesmas imagens nas páginas ímpares no decorrer do texto, seja por meio da linguagem verbal, ao explicitar que "as práticas discursivas abrangem, além dos textos escritos e falados, a integração da linguagem verbal com outras linguagens (multiletramentos)" (PARANÁ, 2008, p. 50).

A análise das linguagens verbal e verbo-visual, no documento, se não apresenta uma contradição, suscita, pelo menos, algumas dúvidas e perplexidade para os que se ocupam de pesquisa com o texto sincrético.

Figura 4: Capa das Diretrizes Curriculares da Educação Básica - Língua Portuguesa.

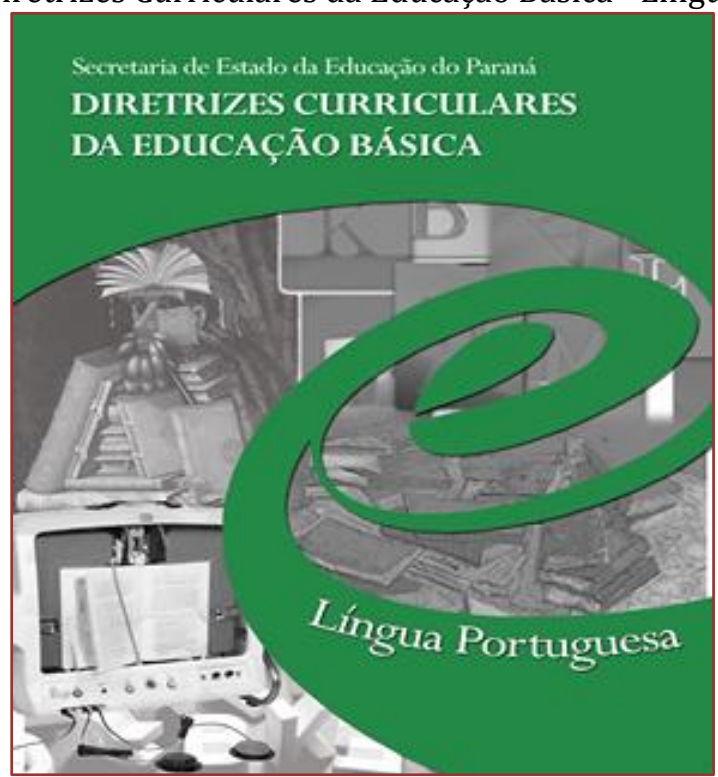

Fonte: Diretrizes Curriculares da Educação Básica - Língua Portuguesa, PARANÁ, 2008. 
Já, na capa, há uma nítida relação de oposição entre a cultura impressa vs. a cultura digital ao mobilizar, em destaque, elementos visuais que remetem à cultura digital. A imagem central é o símbolo "e", de educação, estilizado, na cor verde, sobrepondo-se a diversas imagens em preto e branco; na parte superior, em branco, é definido o autor do documento (Secretaria de Estado da Educação do Paraná), seguido do título, posto em relevo, em letras maiúsculas, fonte maior; na parte inferior esquerda, a especificação "Língua Portuguesa", que define o seu interlocutor, os professores de Língua Portuguesa que atuam na Rede Estadual de Ensino. Em primeiro plano, há a imagem de um computador, em cuja tela vê-se um livro com as páginas em movimento, uma referência ao que é realizado hoje por meio da tecnologia aplicada aos e-books. Apoiada sobre o computador, a imagem de $O$ Bibliotecário (1566), tela de Arcimboldo.

É necessário observar que, embora os PCN (BRASIL, 1998) e as Diretrizes Curriculares da Educação Básica do Estado do Paraná (PARANÁ, 2008) sinalizem para uma metodologia que contemple as formas contemporâneas do uso da linguagem, há uma imprecisão no que concerne ao modo como serão apropriados pelos currículos escolares, uma vez que questões fundamentais ficam sem respostas, tais como: Quais letramentos são necessários para ser um leitor no hipertexto? Como a interatividade, presente nas novas mídias, impacta o trabalho do professor? Como mobilizar as TDIC nas diferentes práticas sociais de leitura e escrita?

Em um movimento com vistas a responder a demandas educacionais contemporâneas, $\mathrm{o}$ atual documento que parametriza a educação Brasileira, a Base Nacional Comum Curricular (BNCC), homologada em 2017, assume uma visão mais afirmativa das tecnologias e dos multiletramentos, uma vez que: "procura contemplar a cultura digital, diferentes linguagens e diferentes letramentos, desde aqueles basicamente lineares, com baixo nível de hipertextualidade, até aqueles que envolvem a hipermídia (Brasil, 2018, p. 70).

A BNCC faz uma abordagem de gêneros verbo-viso-sonoros nas práticas sociais de leitura, oralidade, escrita e análise linguística. Direcionada por esse documento parametrizador e pelas demandas sociais, a instituição escolar precisa desdobrar em sua organização curricular as diversas formas de participação nas práticas sociais letradas contemporâneas em todas as etapas da educação básica. A análise do documento explicita um endereçamento para o trabalho com a cultura digital, para o trabalho com gêneros discursivos que estão presentes nas mídias e na cultura infanto-juvenil, para a prática da curadoria, que vão exigir saber ler e produzir textos nesse novo contexto, bem como saber "Utilizar softwares de edição de texto, de imagem e de áudio para editar textos produzidos em várias mídias, explorando os recursos multimídias disponíveis. (BRASIL, 2018, p. 77).

Geraldi (2010), ao discutir tecnologias nos contextos de ensino-aprendizagem, aponta como produtivo o fato de as novas tecnologias trazerem consigo o direito de expressão a qualquer um, ou seja, o direito de dizer. As mídias contemporâneas possibilitam que a palavra em rede possa alcançar interlocutores diversos, o que não acontece, por exemplo, com as mídias tradicionais. Esse estado de coisas, segundo o pesquisador, instaura uma nova ética da responsividade nas relações virtuais, o que implica novas relações no campo da ética. Essas possibilidades estão previstas, na BNCC, nas práticas de leitura e escrita relativas a gêneros discursivos como podcast, vlog, playlist, fanfic, e-zines, entre outros.

Tal abordagem demanda explorar as dimensões verbo-visuais do enunciado que desempenham papel constitutivo na produção dos efeitos de sentido, por isso a necessidade de serem trabalhados de forma integrada. Nesse sentido, Voloshinov já argumenta que

Quando a atividade mental se realiza sob a forma de uma enunciação, a orientação social à qual ela se submete adquire maior complexidade graças à exigência de adaptação ao contexto social imediato do ato de fala, e, acima de tudo, aos interlocutores concretos. [...] Fora de sua objetivação, de sua realização num material determinado (o gesto, a palavra, o grito), a consciência é uma ficção. [...] enquanto expressão material estruturada (através da palavra, do signo, do desenho, da pintura, do som musical, etc.), a consciência constitui um fato objetivo e uma força social imensa (BAKHTIN/VOLOSHINOV, 1997, p.117-118).

Para Voloshinov, o material determinado refere-se a determinada linguagem e, como observa Brait (2013, p. 47) podemos relacionar aos estudos do verbo-visual - no qual o verbal e o visual estão contemplados em um único plano de expressão, em outras palavras, constituem um enunciado concreto no qual as dimensões verbal e visual se complementam, em uma dinâmica indissociável para a compreensão dos 
efeitos de sentido. Nessa dinâmica, o verbal abrange tanto a modalidade oral quanto a escrita; já o visual se refere à imagem, seja ela estática ou em movimento. Desse modo,

o texto deve ser analisado, interpretado, reconhecido a partir dos mecanismos dialógicos que o constituem, dos embates e tensões que lhe são inerentes, das particularidades da natureza de seus planos de expressão, das esferas em que circula e do fato que ostenta, necessariamente, a assinatura de um sujeito, individual ou coletivo, constituído por discursos históricos, sociais e culturais, mesmo nos casos extremos de ausência, indefinição ou simulação de autoria (BRAIT, 2012, p. 88-9)

Destarte, no contexto digital, a articulação entre os elementos verbais e visuais forma um todo indissolúvel, e demanda dos sujeitos o reconhecimento dessa particularidade. São textos em que a verbovisualidade se apresenta como constitutiva, demandando a junção do verbal ou do visual para produzir sentido (BRAIT, 2012).

\section{ALGUMAS REFLEXÕES}

As interações sociais, influenciadas pela expansão tecnológica, passaram por inúmeras mudanças no processo sócio-histórico. Nesse cenário, as práticas sociais de leitura e escrita vêm demandando o acionamento de diferentes semioses no processo de significação. Considerando os multiletramentos, Rojo (2013) argumenta que isso exige negociar uma crescente variedade de linguagens e discursos, interagindo, interpretando ou traduzindo para além do texto verbal, pois há a necessidade de se vincular com outras formas de significar, outras modalidades de linguagem, chamados "novos escritos" que

"dão lugar a novos gêneros discursivos quase diariamente: chats, páginas, twits, posts, ezines, epulps, fanclips etc. E isso se dá porque hoje dispomos de novas tecnologias e ferramentas de "leitura-escrita", que, convocando novos letramentos, configuram os enunciados/textos em sua multissemiose ou em sua multiplicidade de modos de significar". (ROJO, 2013, p.20)

Nessa esteira, as reflexões elaboradas neste artigo evidenciam como o desenvolvimento das tecnologias impactam os modos como os sujeitos passam a representar o mundo, o que, consequentemente, altera os modos como as aprendizagens se constituem.

A discussão e mobilização de diferentes estratégias nas práticas escolares continuam um desafio, uma vez que as orientações dos documentos parametrizadores da educação não são suficientes para que os professores - sujeitos sócio historicamente constituídos, oriundos de uma formação que se deu no suporte do papel - consigam elaborar o conhecimento agregado ao longo da sua formação, para ensinar e aprender, considerando os letramentos necessários para o trabalho em contexto digital.

\section{REFERÊNCIAS}

[1] BAKHTIN, Mikhail M. Questões de literatura e de estética - a teoria do romance. Tradução do russo por Aurora Fornoni Bernardini et al. São Paulo: UNESP; Hucitec, 1998.

[2] BARROS, D. L. P. Contribuições de Bakhtin às teorias do discurso. In: BRAIT, B. (Org.). Bakhtin, dialogismo e construção do sentido. Campinas: Editora da Unicamp, 1997.

[3] BARTON, David; HAMILTON, Mary. Local Literacies: Reading and writing in one community. London, Routledge, 1998.

[4] BESNIER, N.; STREET, B. Aspects of literacy. In: INGOLD, T. Encyclopedia of anthropology: humanity, culture, and social life. London: Routledge, 1994, p. 527-562.

[5] BRAIT, Beth. Construção coletiva da perspectiva dialógica: História e alcance metodológico. In: FÍGARO, R. (org) Comunicação e análise do discurso. São Paulo: Contexto, 2012, p.79-98.

[6] BRASIL. Secretaria de Educação Fundamental. Parâmetros Curriculares Nacionais: terceiro e quarto ciclos do Ensino Fundamental - Língua Portuguesa. Brasília: MEC/SEF, 1998.

[7] BRASIL. Base Nacional Comum Curricular. Quinta versão homologada. Brasília: MEC/Secretaria de Educação Básica, 2018. Disponível em: http://basenacionalcomum.mec.gov.br/images/BNCC_20dez_site.pdf. Acesso em: 03 abr. 2020 . 
[8] BUCKINGHAM, D. Cultura digital, educação midiática e o lugar da escolarização. Educação Realidade, Porto Alegre, v. 35, n. 3, p. 37-58, set./dez. 2010. Disponível em: <http://www.ufrgs.br/edu_realidade>. Acesso em: 06 jun. 2020 .

[9] COPE, B.; KALANTZIS, M. "Multiliteracies": new literacies, new learning, Pedagogies: An International Journal, v. 4, n. 3, p. 164-195, 2009. Disponível em: <http://newlearningonline. com/ files/2009/03/pedagogiesmlitsarticle1.pdf>. Acesso em: 05 jun. 2020.

[10] COPE, B.; KALANTZIS, M. A pedagogy of multiliteracies: learning by design. Illinois: University of Illinois, 2015.

[11] COSCARELLI, C. V. Textos e hipertextos: procurando o equilíbrio. Linguagem em (Dis)curso, Santa Catarina, v. 9, n. 3, set./dez. 2009.

[12] DALEY, E. Expandindo o conceito de letramento. Trabalhos em Linguística Aplicada, Campinas, v. 49, n. 2, p. 481-491, jul./dez. 2010.

[13] FREIRE, Paulo. Pedagogia da indignação: cartas pedagógicas e outros escritos. São Paulo: UNESP, 2000.

[14] GERALDI, J. W. Onde o ético e o estético se encontram hoje. IN: CÍRCULO - RODAS DE CONVERSA BAKHTINIANA. São Carlos-SP. Universidade Federal de São Carlos, 2010.

[15] GERALDI, J. W. (Org.). O texto em sala de aula. 2. ed. São Paulo: Ática, 1999.

[16] KENSKI, V. M. Tecnologia e ensino presencial e a distância. Campinas - SP: Papirus Editora, 2003.

[17] LEMKE, J. L. Letramento metamidiático: transformando significados e mídias. Trabalhos em Linguística Aplicada, Campinas, v. 49, n. 2, p. 455-479, jul./dez. 2010.

[18] PARANÁ. Secretaria de Estado da Educação. Diretrizes Curriculares da Educação Básica. Curitiba: SEED/DEB, 2008.

[19] REMENCHE, Maria de L. R.; SILVEIRA, Ana P. Aos olhos de uma criança: o videoclipe como prática de letramento. In: INTERDISCIPLINAR: Revistas de Estudos em Língua e Literatura, Ano 12, v. 27, São Cristovão, 2017.

[20] ROJO, R. Gêneros discursivos do Círculo de Bakhtin e multiletramentos. In: Escol@ conectada: os multiletramentos e as TICs. 1. ed. São Paulo: Parábola Editorial, 2013. cap 1, p. 13-36.

[21] SOUZA, A. L. S.; CORTI, A. P.; MENDONÇA, M. Letramentos no ensino médio. São Paulo: Parábola Editorial, 2012.

[22] STREET, B. V. Literacy in theory and practice. Cambridge: CUP, 1984.

[23] STREET, B.V. Letramentos sociais: abordagens críticas do letramento no desenvolvimento, na etnografia e na educação. Tradução Marcos Bagno. São Paulo: Parábola Editorial, 2014.

[24] VOLÓCHINOV, Valentin. Marxismo e filosofia da linguagem: problemas fundamentais do método sociológico na ciência da linguagem. Tradução, notas e glossário de Sheila Grillo e Ekaterina Vólkova Américo. 1. ed. São Paulo: Editora 34, 2017.

[25] XAVIER, Antonio Carlos dos Santos. O Hipertexto na sociedade da informação: a constituição do modo de enunciação digital, 2002. 220f. Tese (Doutorado em Linguística) - Instituto de Estudos da Linguagem. Universidade Estadual de Campinas (UNICAMP). 


\section{Capítulo 13}

A literatura infantil como via de mão dupla: Projetos e ações efetivas do PIBID-UEMG (Subprojeto Leopoldina- MG), nos Anos Iniciais do Ensino Fundamental, de 2012 a 2017

\section{Anicézia Pereira Romanhol Bette}

Resumo: Este artigo possui dois objetivos - apresentar projetos de literatura infantil, produzidos por alunas-bolsistas (Curso de Pedagogia) do PIBID - UEMG, subprojeto da Unidade de Leopoldina (MG), bem como a realização dos mesmos em quatro instituições de Ensino Fundamental (Anos Iniciais), do município de Leopoldina. A partir do acompanhamento da execução desses projetos pelos professores coordenadores de área e professores supervisores e, também, de seminários internos, apresentados pelas alunas-bolsistas, observou-se como o Programa foi essencial para elas no que se refere à utilização da literatura infantil na formação do leitor e como fio condutor de projetos didático-pedagógicos, constatando os resultados in loco.

Palavras-chave: Literatura Infantil; PIBID- UEMG, subprojeto Leopoldina (MG); formação do leitor; prática pedagógica. 


\section{INTRODUÇÃO}

Um dos fatores preponderantes para a melhoria da qualidade da educação brasileira é o investimento na formação do futuro professor, aproximando o graduando de licenciatura do exercício profissional e da inserção na docência, a fim de minimizar a distância entre os modelos idealizados de aluno e de professor, conforme apresentam as teorias curriculares das licenciaturas. Além disso, a vivência do licenciando em ambiente escolar desperta-o para a investigação entre as convergências e divergências dos conhecimentos obtidos no meio acadêmico com a dimensão prática do profissional da educação, buscando repensar as práticas pedagógicas, de acordo com a diversidade de contextos escolares.

Nesse sentido, a Coordenação de Aperfeiçoamento de Pessoal de Nível Superior (CAPES), fundada pelo Ministério da Educação, com o intuito de ampliar e fortalecer a pós-graduação strictu sensu (mestrado e doutorado), no país, assumiu, também, em 2007, dentre suas linhas de ação, o compromisso de qualificar professores da educação básica, sendo estes atuantes ou iniciantes, isto é, aqueles que estivessem cursando licenciaturas.

Das Políticas Públicas no Brasil para a formação de qualidade dos professores, consta o Programa Institucional de Bolsa de Iniciação à Docência (PIBID), com o objetivo de valorizar o magistério e inserir os acadêmicos de licenciaturas, nas escolas públicas, para que possam estabelecer a integração entre educação superior e educação básica, interligando ensino, pesquisa e extensão.

Após a aprovação da proposta do projeto de iniciação à docência, produzida pela Instituição de Ensino Superior que contenha o curso de licenciatura, e firmada a parceria com a rede de educação básica do município ou estado, para que ocorra a participação dos bolsistas do PIBID em atividades, nas escolas, estes serão acompanhados por professores supervisores, também bolsistas. Tais professores, caracterizados pela experiência e excelência no ofício do magistério, atuam nas escolas de educação básica onde os alunos bolsistas desenvolverão suas ações.

Nesse sentido, a escola pública é o espaço no qual os alunos bolsistas irão, na prática, articular os estudos teóricos da graduação com a realidade educacional brasileira, identificando a diversidade de desafios que interferem no ensino e na aprendizagem dos alunos, buscando, junto aos professores supervisores e coordenadores de área, formas de redimensionarem tal cenário, a partir de diálogos, investigações científicas, propostas metodológicas, seminários internos e externos, e cursos de extensão.

A Universidade Estadual de Minas Gerais (UEMG), em formato multicampi, é composta por vinte unidades acadêmicas, sendo cinco, na capital mineira, Belo Horizonte, e quinze, no interior do estado. Dentre os 117 cursos de graduação ofertados, 40 são de licenciatura, distribuídos, nas Unidades, sendo os seguintes: Artes plásticas; Artes Visuais; Ciências Biológicas; Ciências Sociais; Educação Física; Geografia; História; Letras-Português; Letras - Português e Inglês; Matemática; Música, com habilitação em Educação Musical Escolar; Música, com habilitação em Instrumento ou Canto; Pedagogia; e, Química.

O PIBID se constituiu na UEMG, no ano de 2012, com o Projeto Institucional: "As licenciaturas, a UEMG e a Educação Básica: construindo saberes e práticas docentes", por meio de um convênio celebrado entre a UEMG e a Secretaria Municipal de Educação de Leopoldina. Desse projeto, nasceram 11 subprojetos, sendo 05 das unidades de Belo Horizonte e 06, do interior mineiro. De 2012 até março de 2018, quando foi finalizado o último edital do PIBID pela CAPES, muitas experiências foram vivenciadas pela equipe PIBID/UEMG, através de ações efetuadas, nas 41 escolas públicas, onde os subprojetos aconteceram. Durante esse ciclo, inúmeros debates, seminários, fóruns, pesquisas, artigos científicos e livros sobre a formação inicial docente foram produzidos pelas Unidades acadêmicas participantes, gerando novas formas de pensar a relação universidade e educação básica.

A Unidade de Leopoldina participou do PIBID/UEMG, desde de 2012, com o subprojeto do curso de Pedagogia, intencionando formar professores qualificados para o mercado de trabalho e, concomitantemente, viabilizar a melhoria da educação, nas escolas municipais conveniadas sendo o propósito maior desse subprojeto o da efetiva participação e vivências dos alunos bolsistas, nos processos de construção e ampliação das habilidades de leitura dos estudantes, pertencentes aos anos iniciais do Ensino Fundamental.

Sabe-se que "(...) o papel central da leitura não é ler para aprender a ler, mas ler por um claro interesse em saber o que diz o texto para algum propósito bem-definido. (...)" (COLOMER; CAMPS, 2002, p. 90). Os Parâmetros Curriculares Nacionais de Língua Portuguesa (1997, p. 27-28) também afirmam que " A conquista da escrita alfabética não garante ao aluno a possibilidade de compreender e produzir textos em linguagem escrita. 
Essa aprendizagem exige um trabalho pedagógico sistemático". Assim, se o estudante aprende a ler e a escrever, mas não compreende que tais instrumentos lhe servem como forma de resolver seus problemas na prática social e na participação da sociedade como um cidadão, percebe-se que a competência leitora desse aluno foi deficiente.

Para Ezequiel Theodoro da Silva (2002, p.24) "a leitura possibilita a participação do homem na vida em sociedade em termos de compreensão do presente e do passado e em termos de possibilidade de transformação sociocultural futura". Nesse sentido, ela é um instrumento de aquisição, transformação e produção do conhecimento, se for desenvolvida de maneira crítica e reflexiva, sendo uma forma de combater a alienação e de exercer a liberdade.

Nota-se que leitura bem direcionada e realizada proporciona aos leitores uma ampliação de conhecimento de mundo, vocabulário, ideias, desenvolvimento da cognição, reflexões pessoais e sociais e permite aos indivíduos lidarem com os diferentes discursos linguísticos, em sua vida prática. Dessa maneira, é tarefa da escola possibilitar ao seu educando desenvolver os diversos níveis de leitura durante o percurso na Educação Básica. Sobre esse assunto, os professores da Universidade Católica do Chile, Alliende e Condemarín (2005) dizem o seguinte:

A leitura é, fundamentalmente, o processo de compreender o significado da linguagem escrita. Para os que sabem desfrutá-la, ela constitui uma experiência prazerosa que ilumina mundos de conhecimentos, proporciona sabedoria, permite conectar-se com autores e personagens literários que jamais conheceríamos pessoalmente e apropriar-se dos testemunhos dados por outras pessoas, tempos e lugares. Todo esse poder surge a partir apenas de 28 letras do alfabeto que se articulam entre si de maneira quase infinita. (ALLIENDE \& CONDEMARÍN, 2005, p.7)

Contudo, não basta à escola apresentar uma gama de gêneros textuais aos alunos dos Anos Iniciais do Ensino Fundamental, sem antes realizar uma diagnose da turma, com o intuito de saber as suas especificidades e o seu contexto social, para melhor seleção dos textos a serem estudados. Observa-se que é nesse nível de ensino que a maior parte dos estudantes são alfabetizados e, para consolidar tal aprendizado, as práticas pedagógicas, nesse aspecto, devem privilegiar a leitura prazerosa, para que os alunos tenham curiosidade e avidez pelo ato de ler.

Como os textos literários apresentam aos leitores muitos saberes e experiências humanas, a partir da linguagem artística, cercada de recursos relacionados à ficção e a poeticidade, indispensável se torna que o professor estimule essa leitura de fruição, porque conforme afirma Villardi, "para formar grandes leitores, leitores críticos, não basta ensinar a ler. É preciso ensinar a gostar de ler. [...] com prazer, isso é possível, e mais fácil do que parece". (VILLARDI, 1997, p. 2).

Ainda sobre a importância do trabalho com a literatura, no espaço escolar, Abramovich (1995) afirma que "é através duma história que se podem descobrir outros lugares, outros tempos, outros jeitos de agir e ser, outra ética, outra ótica. É ficar sabendo história, geografia, filosofia, sociologia, sem precisar saber o nome disso tudo, e muito menos achar que tem cara de aula". (ABRAMOVICH, 1995, p. 17). Para tanto, o professor é fundamental na mediação entre o aluno e o texto a ser lido, agindo como preparador do campo a ser semeado, criando o ambiente propício, para que o aluno consiga organizar dentro de si e de sua vivência aquilo que irá ler e que lhe proporcionará momentos de imaginação, sonho, liberdade e exercícios de análise crítica. Nessa perspectiva, a literatura se torna uma via de mão dupla, uma vez que um único texto pode proporcionar prazer, conhecimentos de mundo e da língua, abrir campos para pesquisas, estimular as práticas de leitura individual e coletiva, transformar a literatura em outras artes e, tudo isso de uma forma muito sutil e agradável.

Quanto à Literatura Infantil, Coelho (2000) destaca que o que muda é somente o leitor/receptor que é uma criança. Até pouco tempo, ao se falar em literatura infantil, as pessoas desconsideravam o seu valor, reduzindo-a objeto de distração e nivelando-a a brinquedo como meio de envolver a criança, mantendo-a quieta. A literatura infantil foi valorizada, no século $\mathrm{XX}$, a partir da contribuição da psicologia experimental, que revelou os estágios de desenvolvimento da infância à adolescência, tornando-se importante trabalhar a evolução e a formação do adulto. Nota-se que a criança, ao entrar em contato com o objeto livro literário, depara-se com a arte da palavra, permeada de criatividade e fantasia, que representa o mundo e os homens. É nesse contexto que ocorre a comunicação entre o autor adulto e o seu interlocutor, a criança, provocando, assim, uma forma de aprendizagem. 
Para apresentar como os textos artísticos foram empregados, nas práticas pedagógicas entre 2012 e 2017, nas escolas municipais conveniadas foram consultados o livro, PIBID: construindo saberes e práticas docentes (2014); Acervo do PIBID, de Leopoldina; o Relatório semestral (2012); e o Relatórios finais (2013; 2014; 2015; 2016; 2017). Esses relatórios eram produzidos pelos professores supervisores e coordenadores de áreas dos subprojetos de cada Unidade UEMG, em formulário enviado pela Coordenação de Aperfeiçoamento de Pessoal de Nível Superior (CAPES), como forma de apresentar os resultados alcançados por todos os envolvidos no programa.

\section{A LITERATURA COMO PONTO DE PARTIDA - (SUBPROJETOS 2012 E 2013)}

Em 2012, o subprojeto do curso de Pedagogia do Programa Institucional de Bolsa de Iniciação à Docência (PIBID) possuía convênio com duas escolas públicas a seguir: Escola Municipal Professora Maria da Conceição Monteiro de Resende e Escola Municipal Ribeiro Junqueira, favorecendo 555 estudantes participantes. Em cada uma delas havia cinco alunos bolsistas sob a orientação de uma professora supervisora. Após reunião diagnóstica com diretoras, docentes, e equipe PIBID, subprojeto de Leopoldina, constatou-se que um dos maiores desafios de ambas instituições estava na deficiência do desenvolvimento dos alunos no processo de alfabetização, leitura e escrita. Assim, a equipe PIBID se organizou, planejando ações pedagógicas que pudessem redimensionar tal cenário, partindo da literatura, uma vez que esta permite "pensar o imaginário como um vasto campo de possibilidades, que proporciona, entre tantas coisas, a compreensão e a aceitação de diferentes níveis de percepção da realidade, abrindo-se para um sistema participativo, plural, sensível e passível de outras lógicas". (BUSATTO, 2007, p.58)

Segundo o Relatório semestral (2012) foram implementadas nas duas instituições escolares: círculos de leitura literárias na biblioteca escolar e nos jardins da Casa de Leitura Lya Botelho; contações de histórias; declamações de poesias pelas crianças; concursos de poesias; apresentações de peças teatrais, uma, adaptada do livro literário: 0 Aniversário do Rei, de Rosângela Lima, e as outras, abordando temáticas como: o significado da Páscoa e o valor da amizade. A partir de textos literários lidos ou contados pelos bolsistas, as crianças recriavam as histórias, produzindo seus textos, e que, depois, eram lidos, na TV PIBID, criada pelos bolsistas, como estímulo à leitura oral.

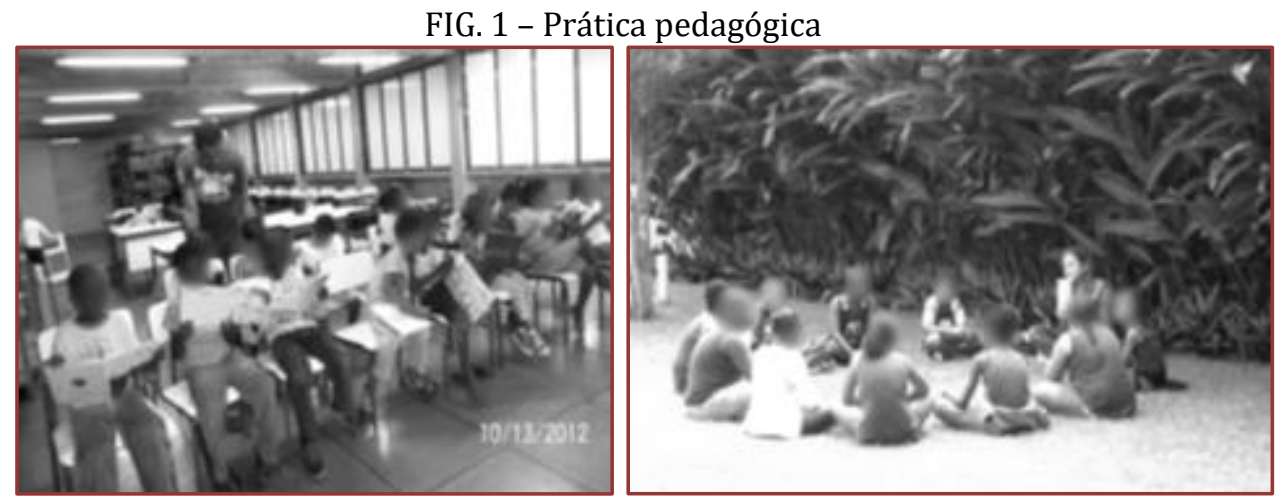

Fonte: Acervo iconográfico da equipe Pibid-UEMG, 2012.

No ano de 2013, o PIBID-UEMG de Leopoldina continuou com o mesmo número de bolsistas e escolas conveniadas Para prosseguir com seu trabalho no âmbito de incentivo à leitura e no processo de alfabetização, elaboraram-se 04 projetos didáticos a partir da literatura em verso e em prosa, que permitiram às crianças desenvolverem, além da prática da leitura, as da linguagem oral e a escrita, e, a criatividade, fortalecendo a socialização dos estudantes, uma vez que os projetos em questão envolviam o diálogo com outras áreas do conhecimento e outras artes como a dramatização, música, dança e as artes visuais. Foram os seguintes projetos realizados nas escolas: "Passaporte da leitura", "Borboletrando", "Algodão doce e poesia" e, "Folclore com pé de moleque", com alunos do $2^{\underline{0}}$ ao $5^{\underline{0}}$ ano. 
O "Passaporte da leitura" foi uma forma prazerosa de estimular a leitura literária aos alunos. As crianças podiam ler durante o recreio ou em casa com a família. Cada um possuía o seu "passaporte", onde era registrado o empréstimo do livro.

FIG. 2 - Projeto "Passaporte da leitura"
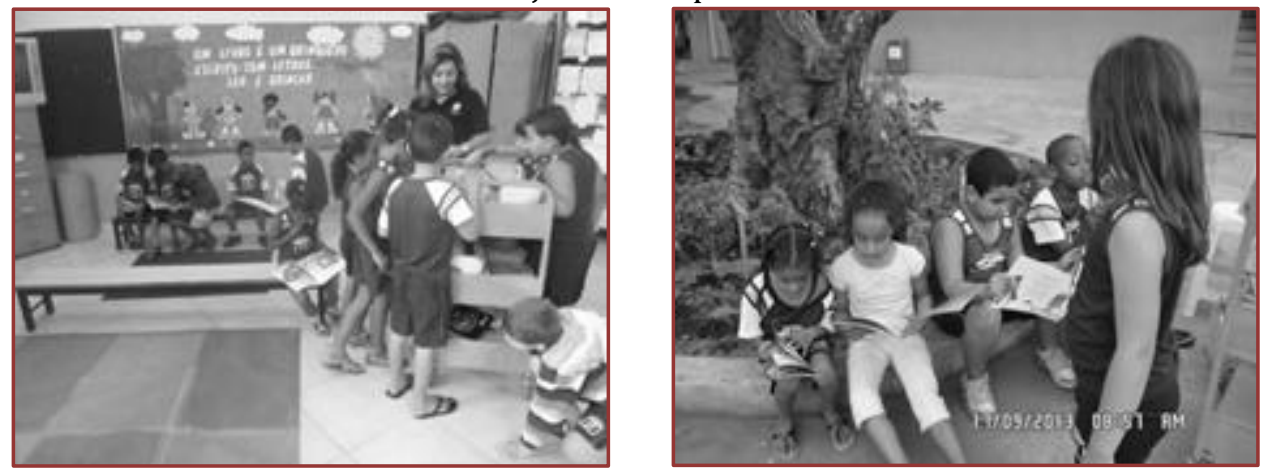

Fonte: Acervo iconográfico da equipe Pibid-UEMG, 2013.

Já "Borboletrando", foi uma peça teatral adaptada do livro A Bela Borboleta, de Ziraldo, que intencionou proporcionar momentos de aprendizagem significativa às crianças, visando trabalhar os aspectos cognitivo, afetivo, moral e ético. Uma atividade em equipe, "que utilizou do teatro como prática pedagógica que contribuiu, para sistematizar a alfabetização (...)". O Projeto foi realizado pela Equipe da Escola Municipal Professora Maria da Conceição Monteiro de Resende. (RELATÓRIO ANUAL, 2013)

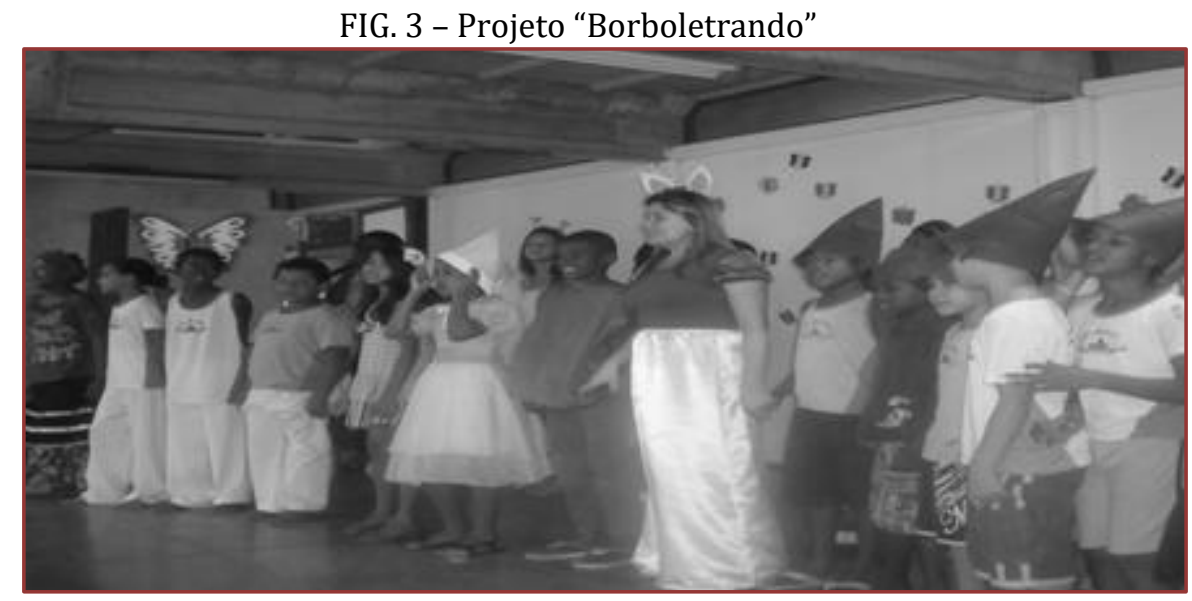

Fonte: Acervo iconográfico da equipe Pibid-UEMG, 2013.

"Algodão doce e poesia" foi um projeto realizado pela equipe PIBID da Escola Municipal Ribeiro Junqueira e " (..) elaborado de forma que os alunos pudessem conhecer um pouco mais da obra de Vinicius de Moraes, suas poesias e músicas, que falam sobre nossa cultura. Elaborou-se uma apresentação com declamações de poesia, instigando nos alunos o interesse pelas artes poéticas (...)". (RELATÓRIO ANUAL, 2013) 


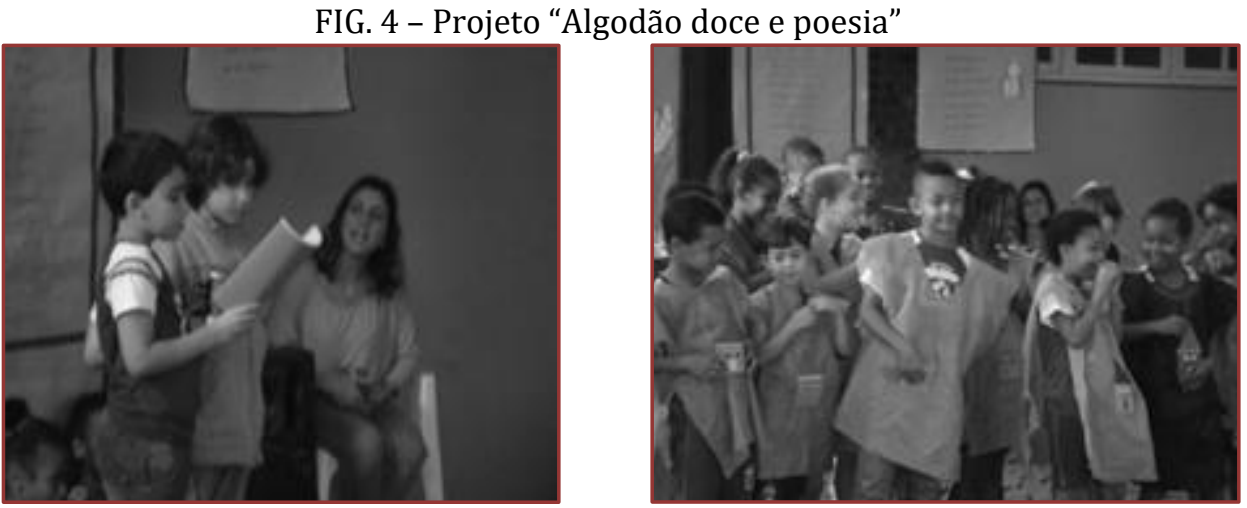

Fonte: Acervo iconográfico da equipe Pibid-UEMG, 2013.

Outro projeto realizado, na Escola Municipal Ribeiro Junqueira, foi o "Folclore com pé-de-moleque", buscando valorizar a cultura local, regional e nacional. As crianças leram e estudaram muitas lendas e parlendas, além de participarem de brincadeiras, danças e músicas folclóricas e dramatizações: “ (...) Puderam, também, saborear as delícias da culinária, produzidas por nosso povo (...)”. (RELATÓRIO ANUAL, 2013)

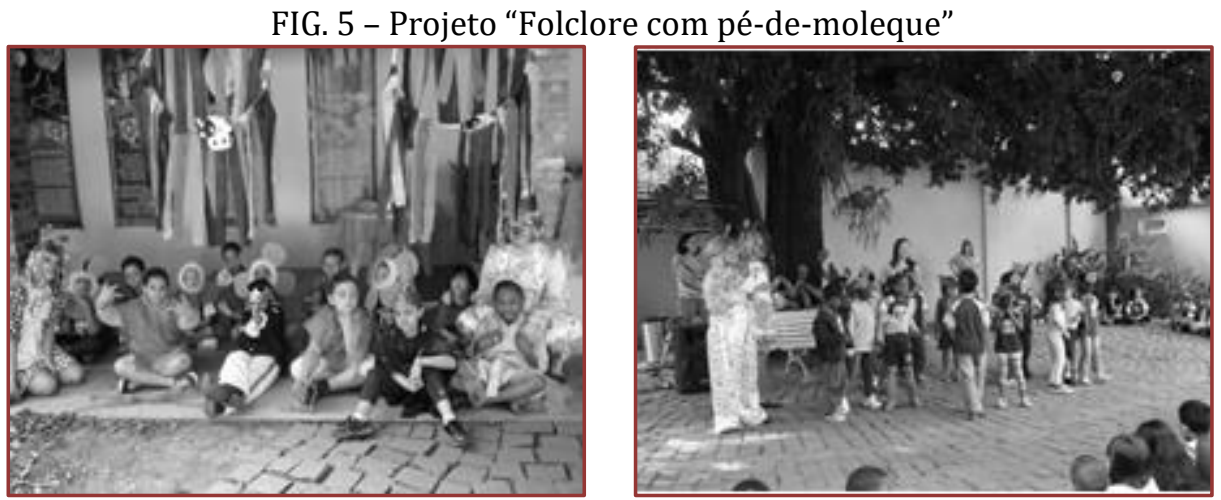

Fonte: Acervo iconográfico da equipe Pibid-UEMG, 2013.

Segundo Coelho (2000), a escola se configura como espaço privilegiado para os estudos literários e é nesse espaço privilegiado que o leitor recebe influências e é estimulado por "atividades programadas", isto é, aquelas atividades em que o aluno participa dentro das salas de aulas ou bibliotecas e, também, as "atividades livres", ou seja, aquelas atividades em que o aluno participa em ambientes como oficinas de criatividades e espaço de invenções.

\section{A LITERATURA COMO TRAVESSIA - (SUBPROJETOS 2014 E 2015)}

A partir de 2014, ampliou-se o número de escolas conveniadas, para quatro, participando do programa, portanto, 1.034 estudantes da rede pública municipal. Automaticamente, duplicou o número de envolvidos do subprojeto de Pedagogia de Leopoldina.

No projeto "Kit de leituras", as crianças levavam uma bolsa, contendo jogos literários e livros da biblioteca da escola, para casa, a fim de lerem e brincarem com a família. "Recontando e Encantando" eram atividades de contação de histórias, para que os alunos pudessem recontar a história, ilustrando-a e reescrevendo-a, uma dessas narrativas foi João esperto, leva o presente certo, de Candace Fleming e G. Brian Karas. 
O "Flanelógrafo itinerante" compunha-se de vários contos infantis, com inúmeros personagens e as crianças poderiam utilizar de todo esse material, para reinventarem contextos. Além desses, os bolsistas realizaram várias adaptações de textos literários, para teatralização com os estudantes, tais como: Maria vai com as outras, de Sylvia Orthof; A lição dos bichos, de Junji Miyaura; Bom dia todas as cores, de Ruth Rocha; Fábulas, de Esopo, com o projeto "Confabulando"; e Os três porquinhos, conto infantil. Houve também o Sarau de poesias, de Cecília Meireles, quando puderam, além de conhecerem a estética dos versos cecilianos, apresentarem-nos ao público escolar (RELATÓRIO ANUAL, 2014).

Em 2015, dentre vários projetos literários viabilizados pela equipe do PIBID - Pedagogia, de Leopoldina, os que mais se destacaram foram: "Abrindo o baú de Monteiro Lobato"; "Oficina de literatura afrobrasileira"; e, "Escrevendo com o escritor".

A Escola Municipal Ribeiro Junqueira idealizou e executou o projeto "Abrindo o baú de Monteiro Lobato" com alunos de três turmas de $5^{\circ}$ ano, dos Anos Iniciais do Ensino Fundamental. Inicialmente, houve uma aula passeio, na Casa de Leitura Lya Botelho, onde os discentes tiveram a oportunidade de conhecerem a vida desse autor, bem como a sua obra, seus personagens e a riqueza literária encontrada em seus textos. Para conhecerem o escritor, apresentou-se sua biografia resumida, através de slides; sobre seus personagens, utilizou-se de fantoches que compunham a sua obra O Sítio do Pica-pau Amarelo; e, para maior compreensão de suas narrativas, foi exibido, em vídeo, um episódio da série regravada pela Rede Globo, quando cada criança usou de sua criatividade, para inventar outros enredos, a partir do que assistiu. 0 resultado do projeto foi a produção de um livro pelos alunos, baseado nos enredos infantis lobatianos.

FIG. 6 - Projeto "Abrindo o baú de Monteiro Lobato"
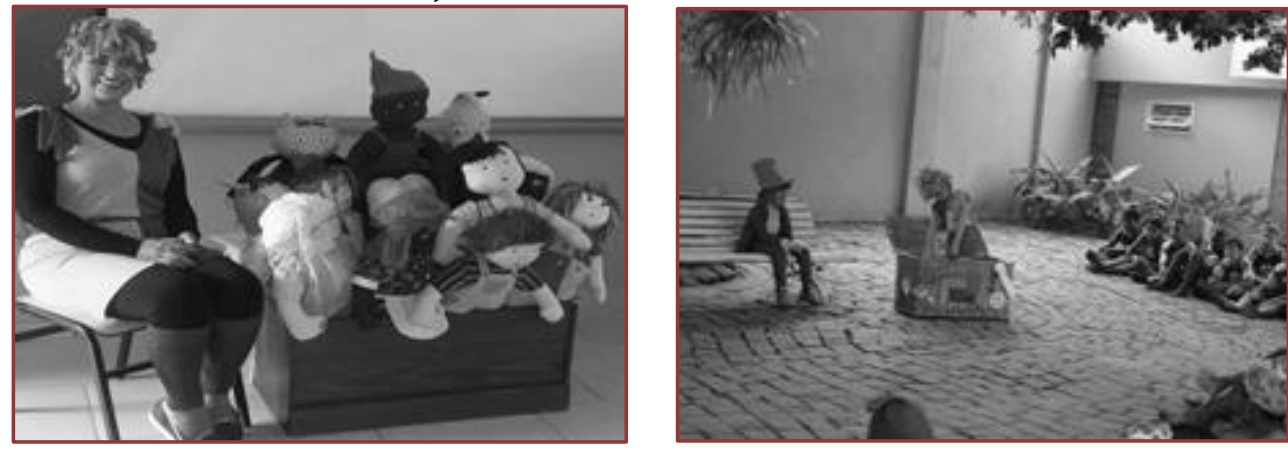

Fonte: Acervo iconográfico da equipe Pibid-UEMG, 2015.

FIG. 7 - Culminância do projeto "Abrindo o baú de Monteiro Lobato"
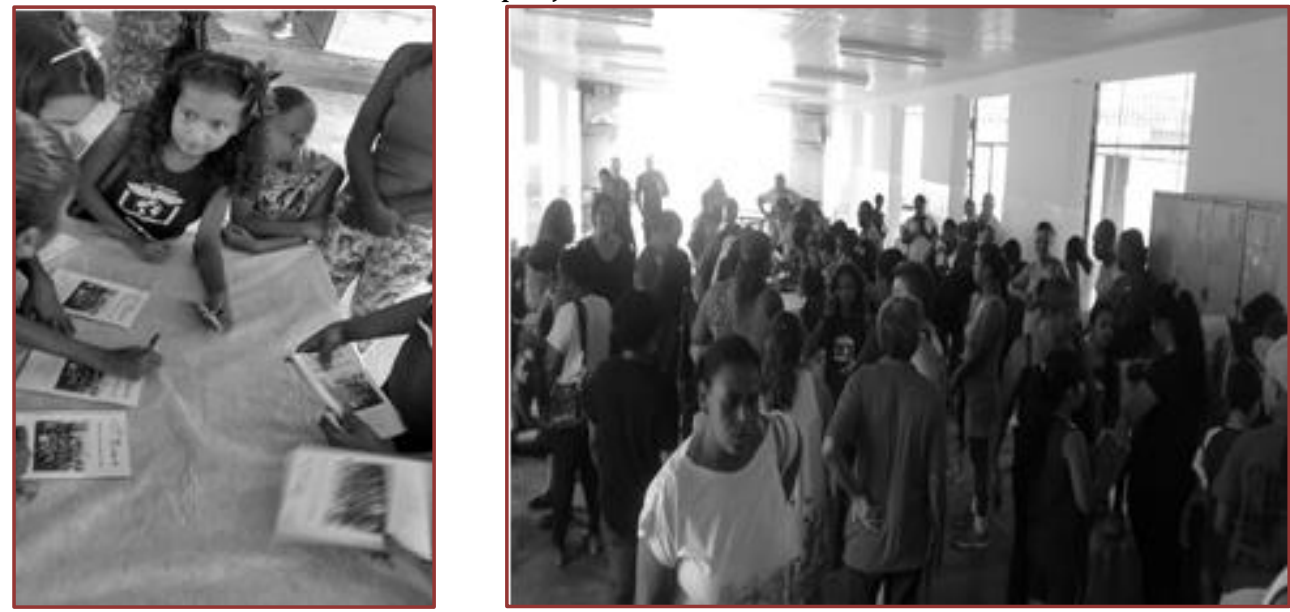

Fonte: Acervo iconográfico da equipe Pibid-UEMG, 2015. 
O projeto "Oficina de literatura afro-brasileira" teve início com a contação de história do livro Obax, de André Neves, quando foi explorado, oralmente, a compreensão do texto, buscando investigar sobre a cultura africana. Depois, os alunos produziram bonecos que representavam a cultura afro-brasileira.

"Escrevendo com o escritor" é um projeto desenvolvido, na cidade de Cataguases, pela professora Andréa Toledo, desde 2005, cujo objetivo é estimular a leitura e a escrita dos estudantes do Ensino Fundamental, utilizando das tecnologias como forma de aproximação de escritores mineiros e seus leitores. Em 2015, as quatro escolas parceiras do PIBID-UEMG de Leopoldina, a saber: Escolas Municipais Botelho Reis, Professora Maria da Conceição Monteiro de Resende, Osmar Lacerda França e Ribeiro Junqueira participaram do projeto. Em Leopoldina, o escritor Silvio Costta, por meio de vídeo, lançou um desafio de escrita para as crianças. Depois disso, os alunos bolsistas do PIBID apresentaram, por slides, a biografia desse autor e uma contação de histórias, A vida de caramujo, do mesmo autor, no jardim da Casa de Leitura Lya Botelho:

A contação de história para os alunos dos $4^{\circ}$ e $5^{\circ}$ anos promoveu debates interdisciplinares sobre o meio ambiente, diversidade cultural e física, respeito às diferenças, entre outros temas. 0 "Projeto Escrevendo com o Escritor" promoveu o encontro dos alunos com o próprio Silvio Costta, na Casa de Leitura Lya Botelho, durante um agradável café da manhã, quando as crianças tiveram a oportunidade de conversar com o autor da obra trabalhada. (RELATÓRIO ANUAL, 2015)

Desse projeto literário surgiram leituras, encontros, aulas-passeio, debates, escrita de um gibi pelos estudantes, concurso de desenho para a capa do gibi, diálogos das crianças com o escritor, jogo de tabuleiro criado pela equipe PIBID, a partir do livro Vida de Caramujo, além de trabalhos em equipe entre discentes, docentes e equipe do PIBID-UEMG de Leopoldina.

A literatura contemporânea estimula o leitor a desenvolver consciência crítica, sua criatividade, capacidade de observação e reflexão, enquanto sujeito em uma realidade que o rodeia. Para tanto, é indispensável que o professor seja mediador de todo o processo da atividade literária com o aluno, a fim de planejar os melhores caminhos que proporcionem o trabalho interdisciplinar, instigando o discente a ampliar a sua visão de mundo. Coelho (2000) diz que:

Em nossa época de transformações estruturais, a noção de literatura que vem predominando entre os estudiosos das várias áreas do conhecimento é a de identificá-la como um dinâmico processo de produção/recepção que, conscientemente ou não, se converte em favor de intervenção sociológica, ética ou política. Nessa "intervenção" está implícita a transformação das noções já consagradas de tempo, espaço, personagens, ação, linguagem, estruturas poéticas, valores éticos ou metafísicos, etc., etc. (...) Para além do prazer/emoção estéticos, a literatura contemporânea visa alertar ou transformar a consciência crítica de seu leitor/receptor. (COELHO, 2000, p. 2829)

FIG. 8 - Culminância do projeto "Escrevendo com o escritor", na casa de Leitura Lya Botelho, em Leopoldina

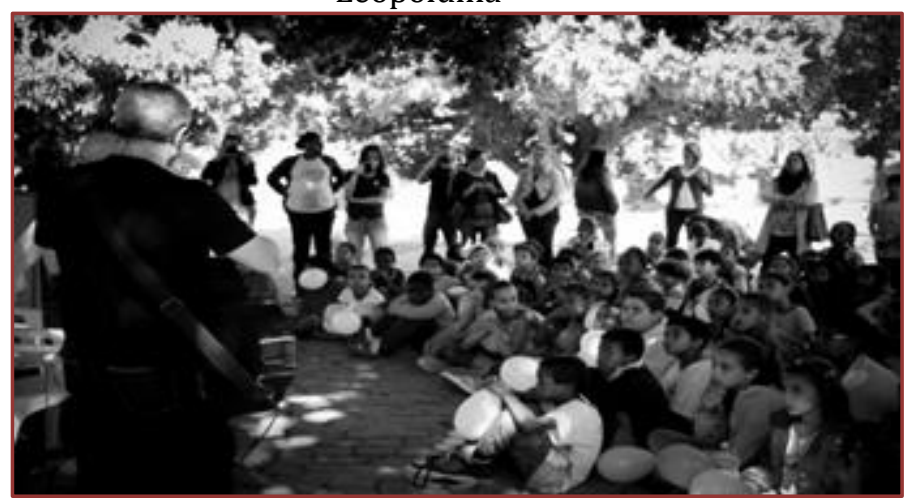

Fonte: Acervo iconográfico da equipe Pibid-UEMG, 2015. 


\section{A LITERATURA COMO VIA DE MÃO DUPLA - (SUBPROJETOS 2016 E 2017)}

Em 2016, três projetos literários, propostos pela equipe PIBID-UEMG de Leopoldina às escolas conveniadas merecem destaque: "Poetizando nos jogos olímpicos"; "Contação de histórias africanas"; e, "Escrevendo com o escritor".

"Poetizando nos jogos olímpicos" foi um projeto que teve como temática as Olimpíadas Rio 2016. Durante a sequência didática, houve leitura, pesquisa e escrita de vários gêneros textuais pelos estudantes do $3^{\circ}$ ao 5o ano, como biografia de Tom Jobim e Vinicius de Moraes; análise da composição musical, Garota de Ipanema, de Tom Jobim; pesquisa das bandeiras dos países envolvidos nas Olimpíadas 2016, seguidas de confecção de cartazes, contendo as características de cada nação; produção de caderno de receitas com as receitas típicas de cada nação; localização dos países no mapa do mundo e muito mais. Contudo, o ponto culminante do projeto foi o concurso de poesias sobre o tema em questão, quando houve votação dos três primeiros lugares pelo corpo docente das escolas:

Encerrando o "Projeto Poetizando nos jogos olímpicos", as crianças do $1^{\circ}$ e $2^{\circ}$ ano fizeram a abertura com as música-tema das olimpíadas Rio 2016. Após a apresentação, houve a premiação dos autores das melhores poesias, quando cada vencedor ganhou a medalha correspondente a sua colocação e um presente pela participação no concurso.

(RELATÓRIO ANUAL, 2016)

FIG. 9 - Projeto "Poetizando nos jogos olímpicos"

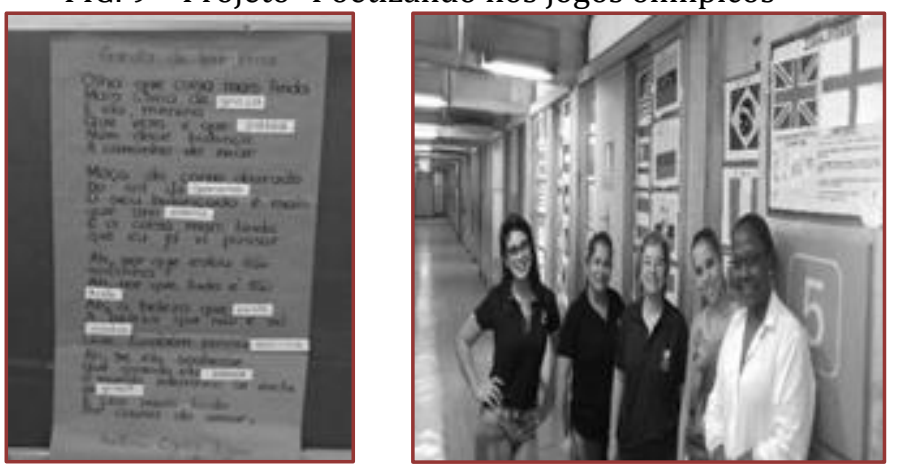

Fonte: Acervo iconográfico da equipe Pibid-UEMG, 2016.

FIG. 10 - Ganhadores do Concurso de Poesia

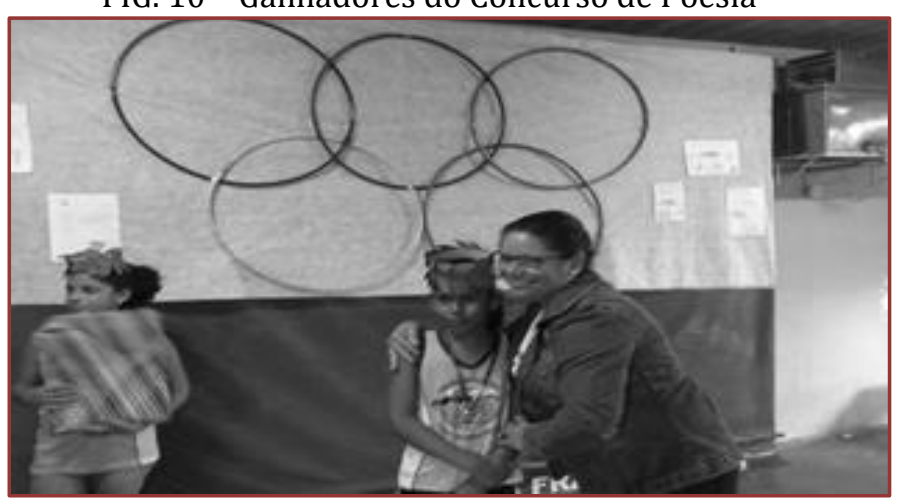

Fonte: Acervo iconográfico da equipe Pibid-UEMG, 2016.

0 projeto "Contação de histórias africanas" foi embasado na Lei Federal no 10.639/03, que tornou obrigatório o ensino de História e Cultura Africana e Afro-Brasileira, na educação básica. Nessa perspectiva, a intenção foi a de abrir campo para discussões sobre o assunto com os alunos do $1^{\text {o }}$ ao $5^{\text {ㅇ }}$ ano. 
A partir das contações de histórias semanais e questionamentos sobre as narrativas, as crianças adquiriram informações da cultura africana, valorizando a importância desta, na origem da formação do povo brasileiro, e toda a contribuição dos negros no desenvolvimento socioeconômico e cultural do Brasil. Assim, foram apresentadas as seguintes narrativas: Chuva de Manga, de James Rumford; As panquecas de Mama Panya, de Cláudia Ribeiro Mesquita; As tranças de Bintou, de Sylviane Anna Diou; Betina, de Nilma Lino Gomes; Plantando as árvores do Quênia, de Claire Nivola; e, O Cabelo de Lelê, de Valéria Belém. Segundo uma das professoras supervisoras

As histórias foram contadas por cada bolsista nas salas de 1o ao 5o ano. Logo após, foram desenvolvidas atividades relacionadas às histórias, para que os alunos conhecessem melhor as personagens, o lugar onde ocorria a história e assim saberem um pouco da cultura africana, estabelecendo relações com a do povo brasileiro. (RELATÓRIO ANUAL, 2016)

FIG. 11 - Projeto "Contação de histórias africanas”

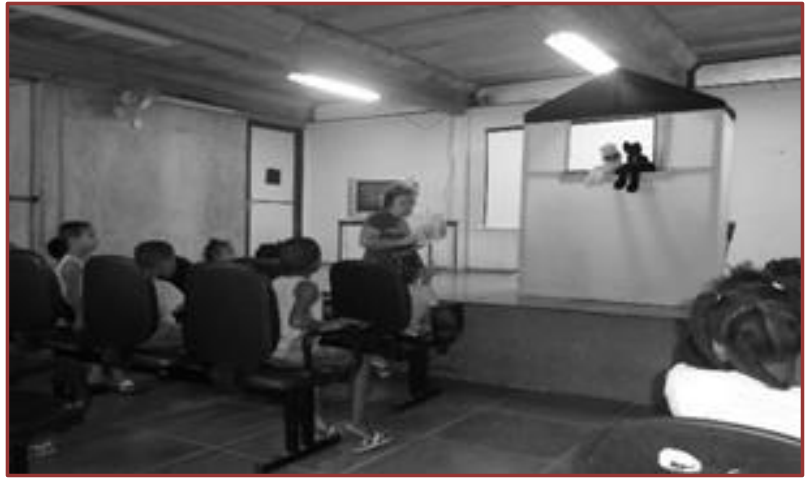

Fonte: Acervo iconográfico da equipe Pibid-UEMG, 2016.

FIG. 12 - Projeto "Contação de histórias africanas"
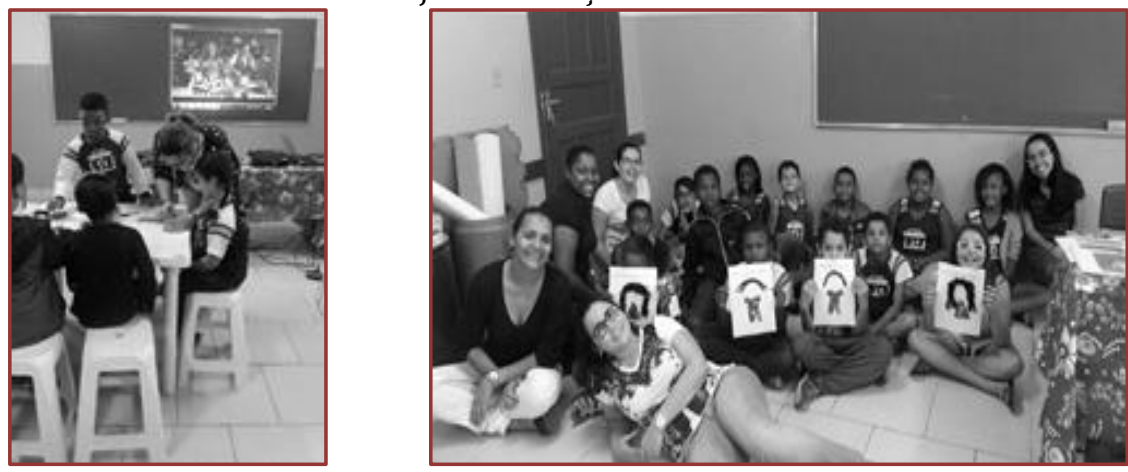

Fonte: Acervo iconográfico da equipe Pibid-UEMG, 2016.

O "Escrevendo com o escritor", edição 2016, em Leopoldina, partiu do livro do escritor cataguasense, Marco Andrade, com a obra 0 príncipe Livrepássaro e o reino dos botões, envolvendo as quatro escolas municipais conveniadas. Para o planejamento do projeto, para que todos os alunos bolsistas e professoras supervisoras tivessem um conhecimento mais profundo sobre o livro literário e os possíveis diálogos com outras áreas do conhecimento, foi oferecido um minicurso pelos coordenadores de área do PIBID-UEMG de Leopoldina e por dois professores convidados, entitulados: Letramento literário e a construção dos sentidos; Letramento literário e letramento digital em consonância; Letramento literário na sala de aula: um estímulo à construção do conhecimento a partir do interacionismo; e, Contribuições da história no processo do letramento literário. 
Com tantos projetos literários desenvolvidos até o presente momento pela equipe PIBID-UEMG, subprojeto de Leopoldina, percebeu-se a necessidade de aprofundar um pouco mais no desenvolvimento das habilidades de leitura das crianças, a fim de irem mais além nas interpretações textuais. Nesse sentido, buscou-se embasamento no letramento literário, que, segundo Cosson (2014), é ampliar os horizontes em relação à construção do ensino da literatura nas escolas, é adentrar o universo literário, navegar por novos caminhos, dar um mergulho mais profundo na leitura realizada.

Dessa forma, os alunos e professores supervisores bolsistas obtiveram conhecimentos, para organizar as práticas de letramento literário, na sala de aula, iniciando pela sequência básica, apresentada por Cosson (2014) que é dividida em quatro passos: motivação, introdução, leitura e interpretação. A motivação é uma forma de preparar o aluno, para receber o texto, sendo uma breve abordagem sobre a essência do texto. 0 segundo passo é a introdução. Nesse momento, o professor apresenta, em linha breve, a obra e o autor, ressaltando a relevância da leitura da obra e chamando a atenção dos alunos para a leitura dos elementos paratextuais. Já o terceiro passo é a leitura, que deve ser acompanhada pelo professor, no intuito de atingir os objetivos pelo qual foi proposta. Nessa etapa, o professor deve auxiliar nas dificuldades encontradas pelo aluno ao longo da realização da leitura, ajudando-o, na interação com o texto, a decifrar a escrita, na tradução dos signos e problemas relacionados ao vocabulário. Essa intervenção pedagógica, além de ajudar ao aluno a adentrar no mundo literário, também pode evitar que ocorra o abandono da leitura por parte dele, que ao longo do tempo, perde o interesse pelo texto, por enfrentar dificuldades relacionadas ao processo de leitura. Já a última etapa é a interpretação, quando cada leitor terá sua própria experiência com a leitura, interpretando-a de forma única e extraindo seu próprio sentido e significado ao texto lido. Entretanto, essa etapa deve ser realizada de forma compartilhada, onde o leitor se envolva com o autor, com o texto e a comunidade escolar, dialogando entre si e assim ter novas visões do texto lido:

$\mathrm{Na}$ escola, entretanto, é preciso compartilhar a interpretação e ampliar os sentidos construídos individualmente. A razão disso é que, por meio do compartilhamento de suas interpretações, os leitores ganham consciência de que são membros de uma coletividade e de que essa coletividade fortalece e amplia seus horizontes de leitura. (COSSON, 2014 p.66)

Após a capacitação da equipe PIBID, os bolsistas desenvolveram atividades pedagógicas em cada escola, que se constituíram da sequência básica de Cosson (2014). Para tanto, houve contação de história com o recurso de fantoches, leitura da biografia do autor, leitura coletiva do livro, analisando texto verbal e não verbal, e, comparações do enredo com a vida individual, social e com os fatos históricos. 0 autor também contou a sua história por vídeo e os alunos se entusiasmaram mais ainda com a narrativa.

Esse projeto proporcionou às crianças possibilidades de trabalho com a leitura, oralidade, escrita, arte visual, e cênica, utilizando de recursos tecnológicos, hajam vistos os seguintes depoimentos de alguns professores supervisores:

(...) foi proposto aos alunos do $5^{\circ}$ ano do Ensino Fundamental I, que confeccionassem um pássaro, utilizando recursos como: argila, água, pincel e tinta guache, criando assim suas próprias esculturas. (...).

"O príncipe Livrepassáro e o reino dos botões" foi trabalhado com os alunos dos $5^{\circ}$ anos, com o intuito principal de trabalhar as diferenças, e as aceitações das diversidades. A partir daí, os alunos montaram uma representação do livro, fazendo uma analogia, de forma que os mesmo pudessem representar as diferenças, descontruindo o determinismo imposto sob alguns grupos sociais. (...)

0 projeto resultou em um lindo livro com histórias escritas e ilustradas pelos alunos do 5ํ ano do Ensino Fundamental I, nos quais os personagens de Marco Andrade puderam vivenciar novas experiências saídas da imaginação desses "alunos autores". Os livros foram confeccionados pelas bolsistas e entregues pelos alunos do 5ํa ano para presentearem o escritor "Marco Andrade", no evento, "Escrevendo com Escritor", que foi realizado na "Escola Municipal Professora Maria da Conceição Monteiro de Resende" (CAIC). Para incentivar a produção de textos individuais, foram utilizados os recursos do teatro; dança; música; contação de histórias e aula-passeio (...). ( RELATÓRIO ANUAL, 2016) 


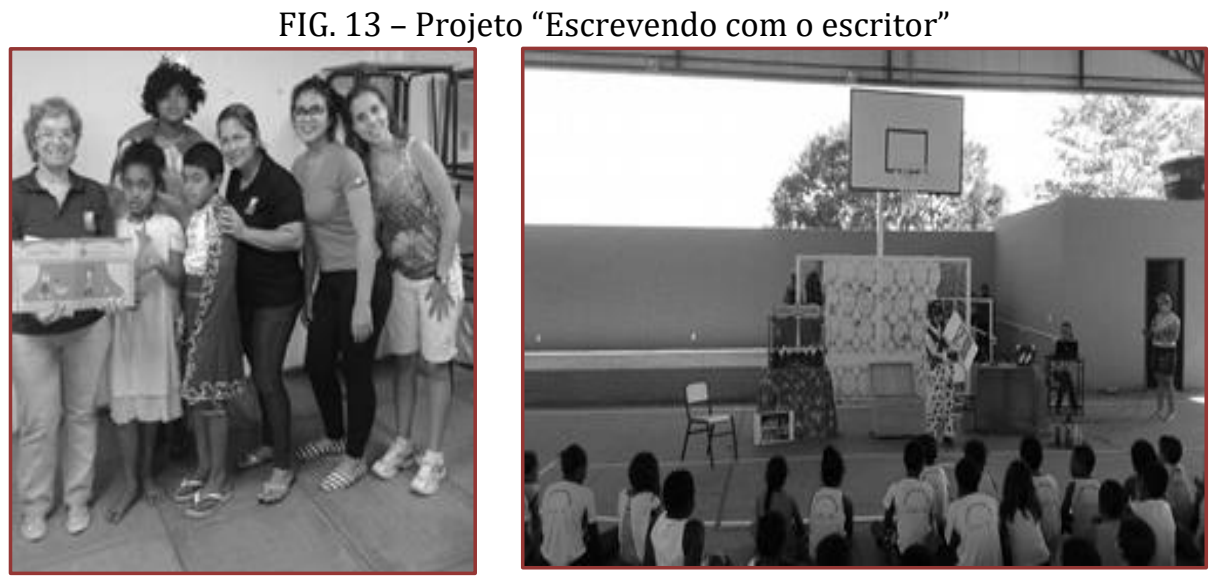

Fonte: Acervo iconográfico da equipe Pibid-UEMG, 2016.

FIG. 14 -Culminância do projeto "Escrevendo com o escritor"
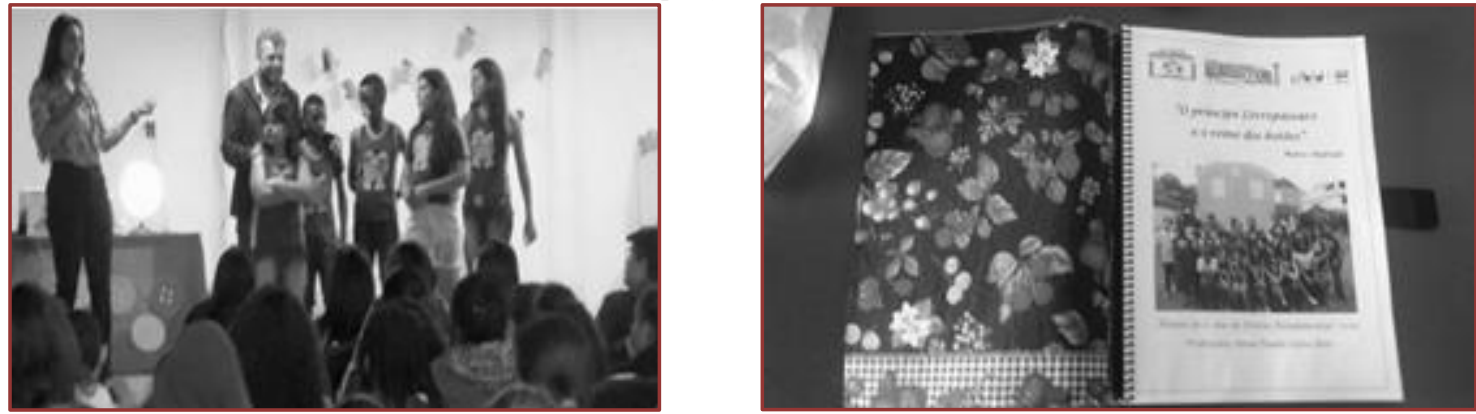

Fonte: Acervo iconográfico da equipe Pibid-UEMG, 2016.

FIG. 15 - Culminância do projeto "Escrevendo com o escritor"

(da direita para a esquerda: Andréa Toledo, idealizadora do projeto Escrevendo com o escritor; Rodrigo Fialho, coordenador de área do PIBID-Leopoldina; Marco Andrade, escritor cataguasense; e, Anicézia Romanhol, coordenadora de área do PIBID-Leopoldina)

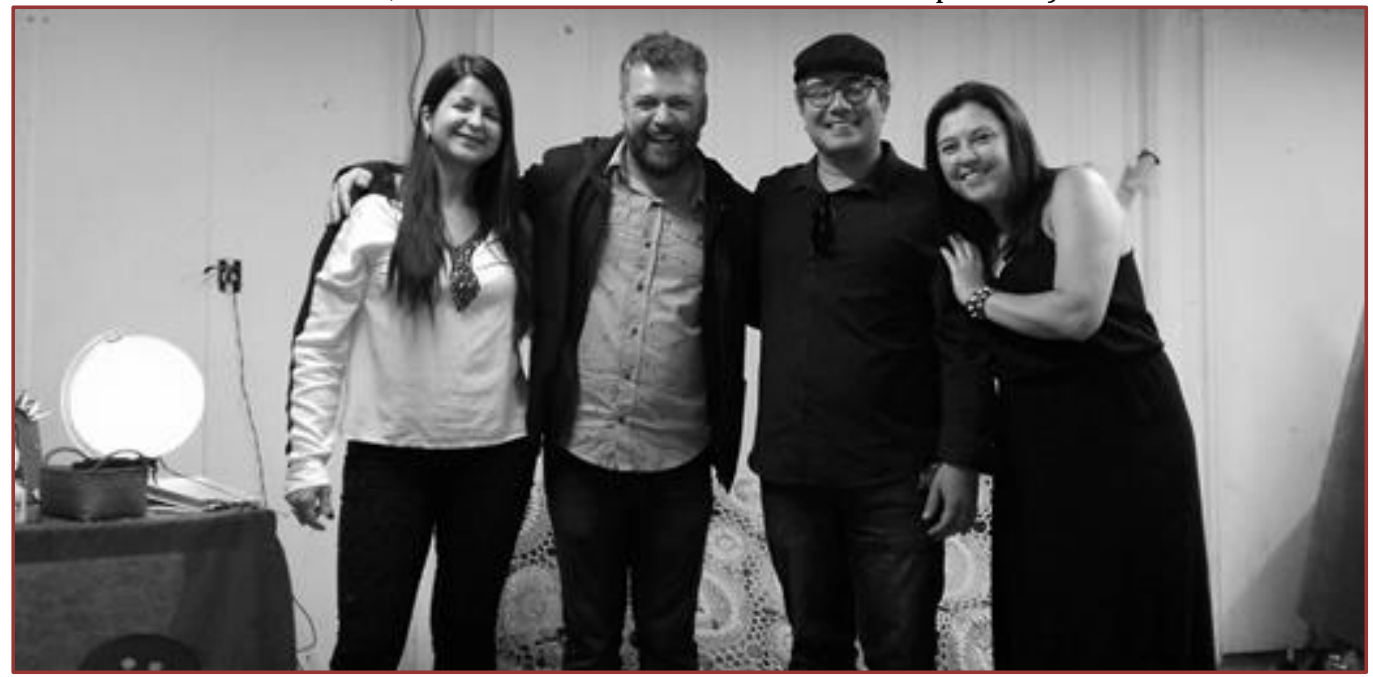

Fonte: Acervo iconográfico da equipe Pibid-UEMG, 2016.

Em dezembro de 2016, a equipe do PIBID-UEMG de Leopoldina se reuniu, para avaliar os resultados dos projetos, executados nas escolas conveniadas, e, para autoavaliação dos envolvidos. 
Diante de tantos avanços alcançados tanto pelos bolsistas, em sua formação docente, quanto pelos alunos participantes, no desenvolvimento com as linguagens, notaram que era necessário investir nos temas transversais, pois muitos alunos tinham dificuldades de seguir regras, de respeitar a diversidade humana e de autoconhecerem-se. Isso, de alguma forma, comprometia a qualidade do aprendizado. De acordo com os Parâmetros Curriculares Nacionais: temas transversais (1997):

O compromisso com a construção da cidadania pede necessariamente uma prática educacional voltada para a compreensão da realidade social e dos direitos e responsabilidades em relação à vida pessoal, coletiva e ambiental. Nessa perspectiva é que foram incorporadas como Temas Transversais as questões da Ética, da Pluralidade Cultural, do Meio Ambiente, da Saúde e da Orientação Sexual. (Brasil, 1997, p. 15)

Assim, cada grupo de bolsistas buscou, no mês de janeiro de 2017, sob a orientação do professor supervisor, investigar mais a fundo a temática transversal que deveria ser trabalhada, no próximo projeto, na escola onde estava inserido. A literatura, mais uma vez, seria a disparadora para a realização de atividades com a leitura, a oralidade e a escrita, numa perspectiva interdisciplinar, instigando possíveis transformações de pensamento e comportamento no público alvo. 0 objetivo da interdisciplinaridade nos projetos era de o aluno, mediado pelo professor desafiador, construir um conhecimento global do tema estudado, articulando saberes de forma crítica. Para Silva (1999):

Não compete mais ao aluno efetuar a unidade do conhecimento mediante unicamente seu próprio esforço: a escola, através de seus docentes, deve oferecer aos alunos um conhecimento interdisciplinar, com a contribuição das diferentes disciplinas para uma pesquisa globalizante. (SILVA, 1999, p.68)

No início de fevereiro, os quatro grupos de bolsistas do subprojeto de Leopoldina, juntamente, com seus professores supervisores e coordenadores de área se reuniram, a fim de apresentarem os projetos uns para os outros, demonstrando as sequências didáticas e a correlação com a transversalidade e a interdisciplinaridade. Em seguida, concluíram que os projetos didáticos apresentados eram muito pertinentes ao contexto de todas as escolas conveniadas e que, logo após encerrarem o primeiro projeto, por volta de dois meses, todos os grupos de bolsistas poderiam utilizar-se dos projetos uns dos outros, o que perfazeriam 04 projetos literários transversais e interdisciplinares para o ano de 2017. É preciso evidenciar que além das características transversais e interdisciplinares, os projetos deveriam investir no brincar, o que denominou o nome geral dos projetos de RecreAÇÃO.

Pensou-se em empregar das brincadeiras nos projetos com a intenção de ocorrer as interações sociais, de as crianças desenvolverem atitudes como paciência, solidariedade, respeito às diferenças, convivência pacífica, apreciação do trabalho alheio, compreensão da interdependência dos indivíduos nos jogos e nas brincadeiras, resiliência e proatividade, aprendendo seguir as regras do jogo. Segundo Lev Semenovich Vygotsky:

A criação de uma situação imaginária não é algo fortuito na vida da criança; pelo contrário, é a primeira manifestação da emancipação da criança em relação às restrições situacionais. 0 primeiro paradoxo contido no brinquedo é que a criança opera com um significado alienado numa situação real. 0 segundo é que, no brinquedo, a criança segue o caminho do menor esforço - ela faz o que mais gosta de fazer, porque o brinquedo está unido ao prazer - e ao mesmo tempo, aprende a seguir os caminhos mais difíceis, subordinando-se a regras e, por conseguinte renunciando ao que ela quer, uma vez que a sujeição a regras e a renúncia a ação impulsiva constitui o caminho para o prazer do brinquedo. (VYGOTSKY, 1998, p. 130)

Os quatro projetos didáticos produzidos, em 2017, foram os seguintes: "Brincadeiras de ontem, hoje e sempre", "Valorização da amizade", "Casulo" e "Diversidade e Literatura: prática lúdica de trabalhar a diferença na escola". 
"Brincadeiras de ontem, hoje e sempre" foi criado pelos bolsistas da Escola Municipal Professor Botelho Reis e teve como objetivo apresentar às crianças as brincadeiras do passado, integrando família e escola, instigando a convivência salutar, muitas vezes prejudicada pelo uso inadequado dos celulares. Nesse aspecto, Maria Dinorah afirma que:

A tecnologia, na verdade veio para servir o homem. Mas se esse homem não tiver acesso à cultura e ao conhecimento, que tem suas bases na palavra escrita, essa mesma tecnologia poderá escravizá-lo e empobrecê-lo cada vez mais. Isso porque, atrás do teatro, do cinema, do rádio e da tv, mesmo para a mais simples comunicação, a palavra escrita é essencial, e o livro, como material de pesquisa e ilustração indispensável. (DINORAH, 1996, p.28)

A partir do livro literário Bolha de sabão, de Letícia Gelli, as bolsistas contaram às crianças do $2^{\circ}$ e $3^{\circ}$ anos a grande aventura de Kátia, à procura da terra das bolhas de sabão. Após questionamentos sobre a perigrafia do livro, biografia da autora e narrativa, numa roda de conversa, as crianças se expressaram sobre o que sabiam dos brinquedos de ontem e de hoje, fazendo perguntas e reflexões. Em outro momento, pais, avós ou tios das crianças foram à escola para falarem sobre como brincavam, quando crianças, comparando tais brincadeiras com as de hoje. Depois, os alunos fizeram pesquisas sobre o que foi citado pelos familiares, compartilharam informações e estudaram as tipologias textuais instrucionais. A proposta interdisciplinar foi com a disciplina de artes e educação física, pois, depois de compreenderem as instruções dos jogos, os estudantes iriam confeccionar os brinquedos, organizá-los e brincar com eles durante o recreio ou nas aulas de educação física. Os brinquedos confeccionados foram: Cama de gato, Amarelinha, Bolhas de sabão, Pega varetas, Coelhinho sai da toca e Três Marias. A última tarefa dos estudantes foi a de criar um jogo, produzindo um texto instrucional, compartilhando-o com a turma, para que pudessem brincar conjuntamente. A perspectiva transversal do projeto se conectou à ética, pluralidade cultural e à saúde física, mental e social.

FIG. 16 -"Brincadeiras de ontem, hoje e sempre”
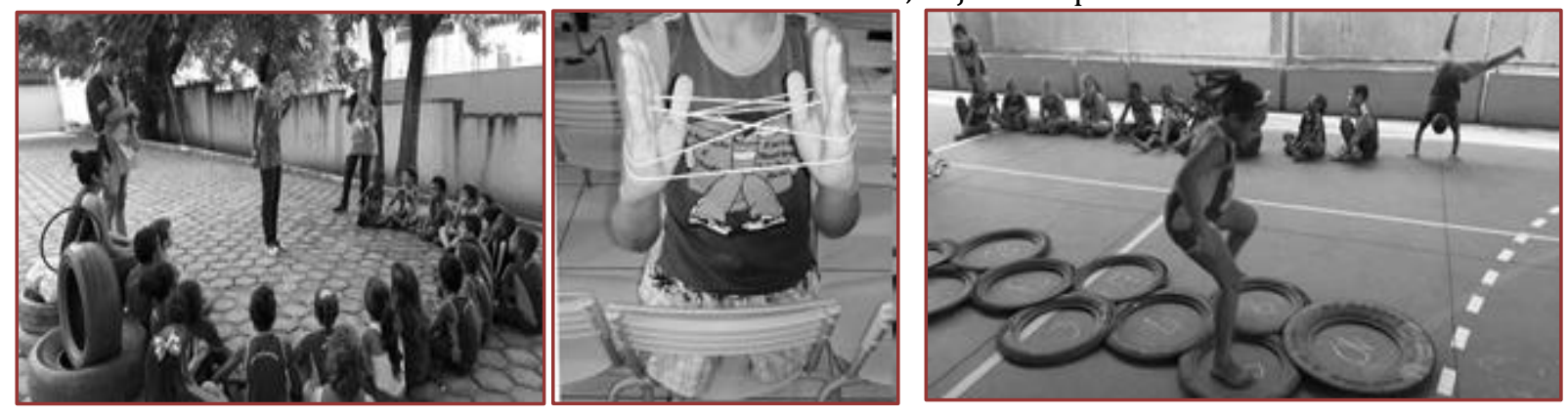

Fonte: Acervo iconográfico da equipe Pibid-UEMG, 2017.

"Valorização da amizade" foi elaborado pela Escola Municipal Ribeiro Junqueira e executado com todos os alunos do $1^{\circ}$ ao $5^{\circ}$ ano. A perspectiva transversal do projeto se relacionou à ética, pluralidade cultural e saúde social. Os textos literários lidos ou contados e estudados, como mola propulsora para discussões e reflexões foram: Não-me-esqueças, desabrochar de uma amizade, de Michael Broad (1ำ e 2ํo anos); Quando eu não consigo, de Ruth Rocha e Dora Lorch (3ํano); Um amigo diferente?, de Claudia Werneck (4ํano); e A menina do Anel, de Bia Bedran (5o ano). Destes livros surgiram inúmeras atividades como: bingo da amizade (palavras), correio da amizade (produção de cartas), A teia da amizade (dinâmica), coral de alunos, produção de personagens com materiais recicláveis e dramatização a partir dos livros literários. Os alunos do 5o ano ouviram a história do Pequeno Príncipe (adaptado), de Antoine Saint Exupery, de uma forma diferente, de olhos vendados, a fim de imaginarem melhor a narrativa, para depois associarem o enredo à vida real. A culminância do projeto ocorreu na Casa de Leitura Lya Maria Muller Botelho, com apresentação de teatro, música e contação de história. 
FIG. 17 -Contação de história pelas bolsistas
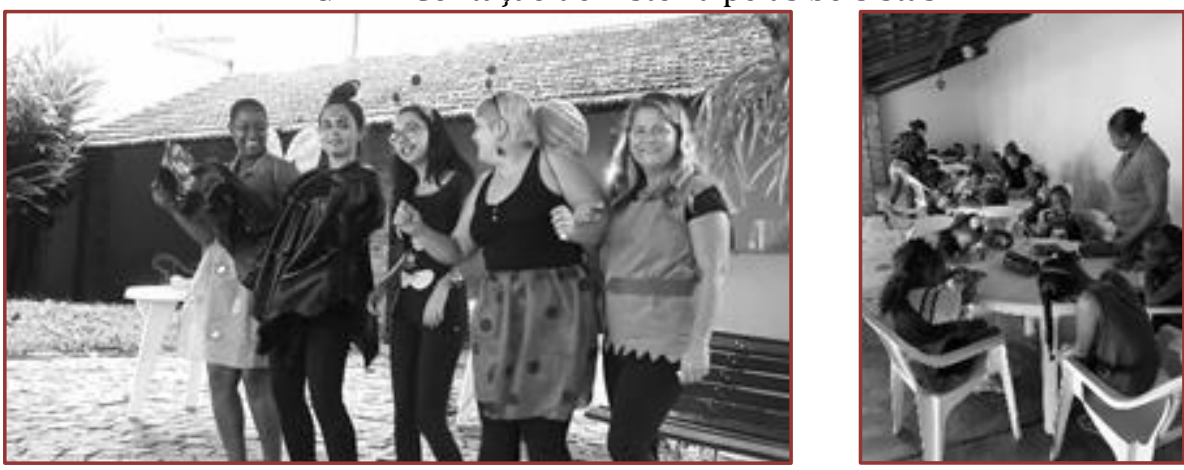

Fonte: Acervo iconográfico da equipe Pibid-UEMG, 2017.

FIG. 18 -Atividades realizadas pelas crianças
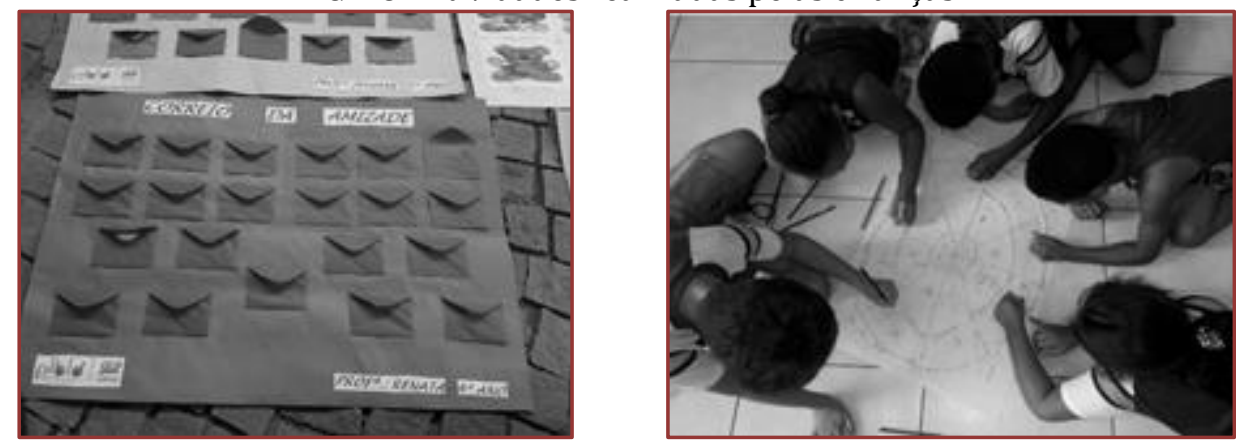

Fonte: Acervo iconográfico da equipe Pibid-UEMG, 2017.

FIG. 19 -Culminância do projeto Valorização da amizade.
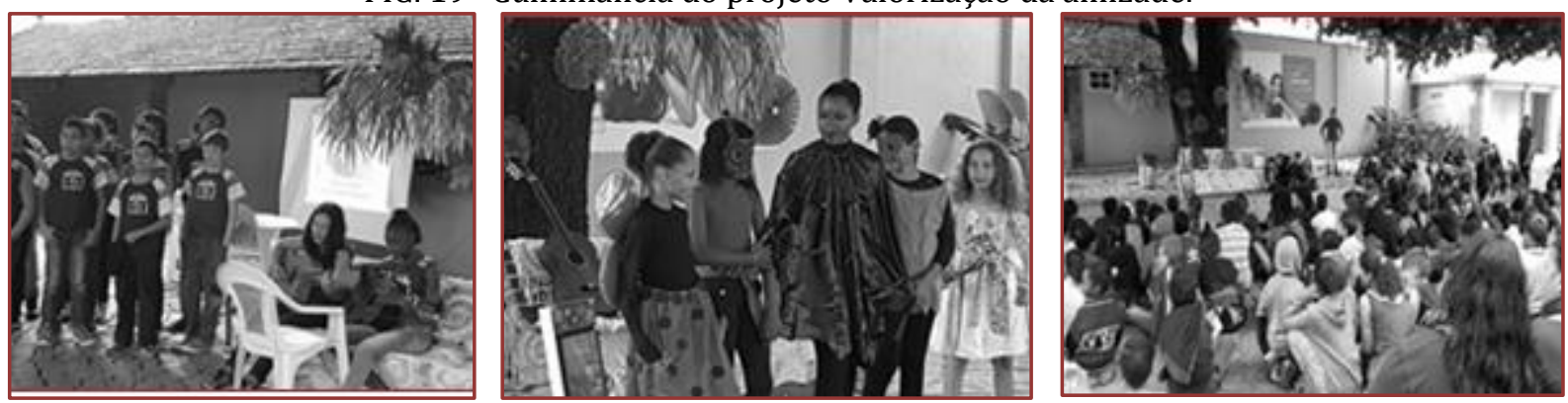

Fonte: Acervo iconográfico da equipe Pibid-UEMG, 2017.

O terceiro projeto, "Casulo", foi produzido pela equipe de bolsistas da Escola Municipal Osmar Lacerda França, que foi dividido em três fases e enfatizou dois assuntos: os variados tipos de famílias na atualidade, e, identidade. Essas temáticas dialogaram com os temas transversais pluralidade cultural, ética e saúde social. De acordo com a professora supervisora dessa escola:

O projeto foi baseado em 0 livro da Família, de Todd Parr, que descreve as famílias desde as mais tradicionais até as famílias modernas, os novos casais. 0 objetivo foi fazer com que as crianças entendessem a importância de conhecer e reconhecer as semelhanças e diferenças existentes entre as diversas famílias e principalmente descobrir, dentro de seu meio social, ou seja, a escola, como se configuram as famílias de seus colegas, desenvolvendo assim o respeito ao diferente da sua composição familiar e o respeito ao próximo. (RELATÓRIO ANUAL, 2017) 
O livro acima citado foi contado para todas as turmas do $1^{\circ}$ ao $5^{\circ}$ ano dessa instituição escolar. A partir da mediação das bolsistas, os alunos refletiram sobre as diversas configurações familiares existentes e a necessidade de todos respeitarem essas diferenças. Desse texto, surgiram duas atividades artísticas, a primeira com os alunos do $1^{\underline{0}}$ e $2^{\circ}$ anos, que pintaram em cada dedo os membros de sua família e apresentaram a música Família Original, do grupo 3 Palavrinhas; a segunda foi com os alunos do 3ํㅜㄴ 4ํㅡㄹ e $5^{\text {o }}$ anos, que, divididos em duas equipe, formaram um grupo para o coral, apresentando a música Trem Bala, de Ana Vilela, e o outro que montou uma peça teatral sobre os variados núcleos familiares, sendo todas essas exibições realizadas na culminância do projeto, para a comunidade escolar e os familiares dos estudantes.

FIG. 20 -Apresentação musical do Projeto "Casulo"
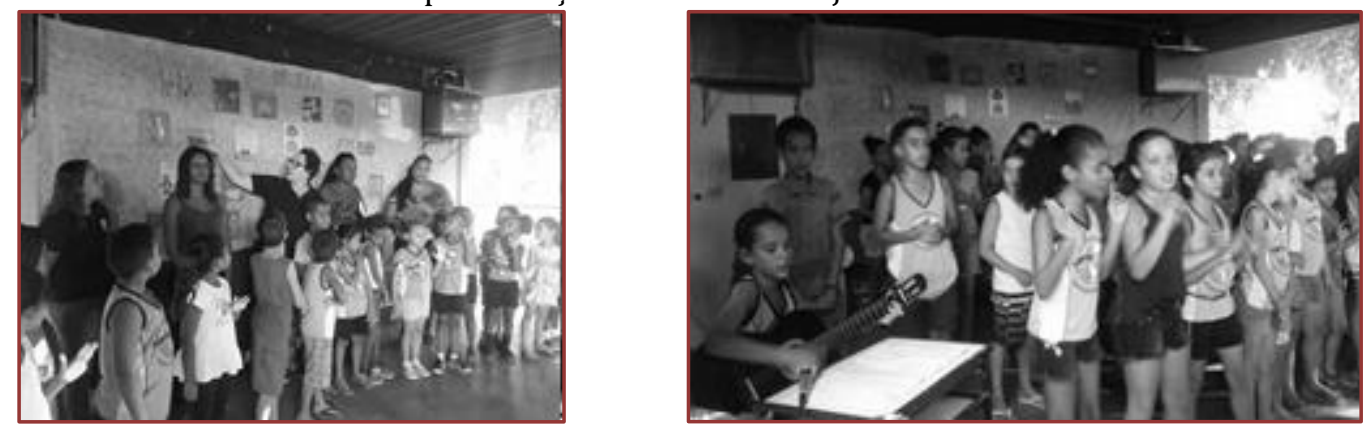

Fonte: Acervo iconográfico da equipe Pibid-UEMG, 2017.

A próxima fase do projeto "Casulo" foi instigar nos alunos o autoconhecimento, uma forma de auxiliá-los na construção de sua formação identitária, no aprendizado do autoamor e no respeito às diferenças. Sabese que é de suma importância refletir com as crianças a respeito das transformações ocorridas na sociedade e que não se deve reproduzir comportamentos viciosos como o preconceito racial, social, cultural, de gênero, de orientação sexual, etc. Nessa perspectiva, Silva diz que:

A diferença pode ser construída negativamente - por meio da exclusão e da marginalização daquelas pessoas que são definidos como "outros" ou forasteiros. Por outro lado, ela pode ser celebrada como fonte de diversidade, heterogeneidade e hibridismo, sendo vista como enriquecedora é o caso dos movimentos sociais que buscam resgatar as identidades sexuais dos constrangimentos da norma e celebrar a diferença. (SILVA, 2000, p.50)

Para tanto, as alunas bolsistas do PIBID trabalharam com o poema "Identidade", de Pedro Bandeira, realizando uma roda de conversa, imbuída de várias análises. Também aplicaram a dinâmica do espelho e produziram um RG simbólico com as crianças, informando-lhes a importância desse documento no meio social. Na produção textual, foi proposto o tema: Quem sou eu? Os estudantes de 3ํㅜㄴ 4o e $5^{\circ}$ anos se autodescreveram física e emocionalmente, falaram sobre seus sonhos, seus talentos e seus desafios. Já os de $1^{\circ}$ e $2^{\circ}$ anos desenharam seu autorretrato.

FIG. 21 - 2ª fase do Projeto "Casulo" - Quem sou eu?
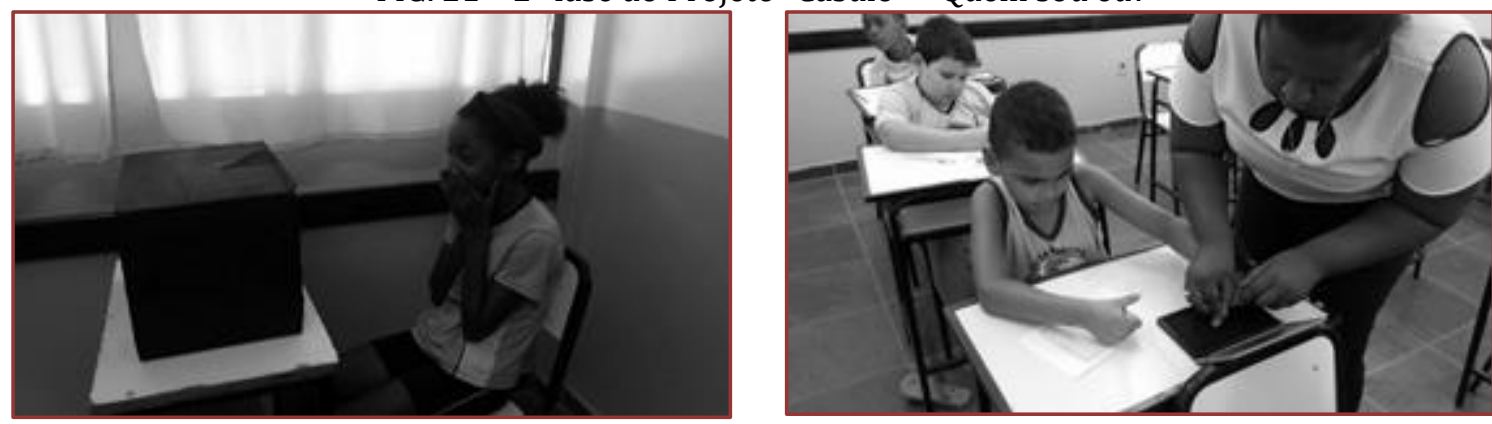

Fonte: Acervo iconográfico da equipe Pibid-UEMG, 2017. 
FIG. 22 - 2 a fase do Projeto "Casulo" - Produção de textos - Quem sou eu?
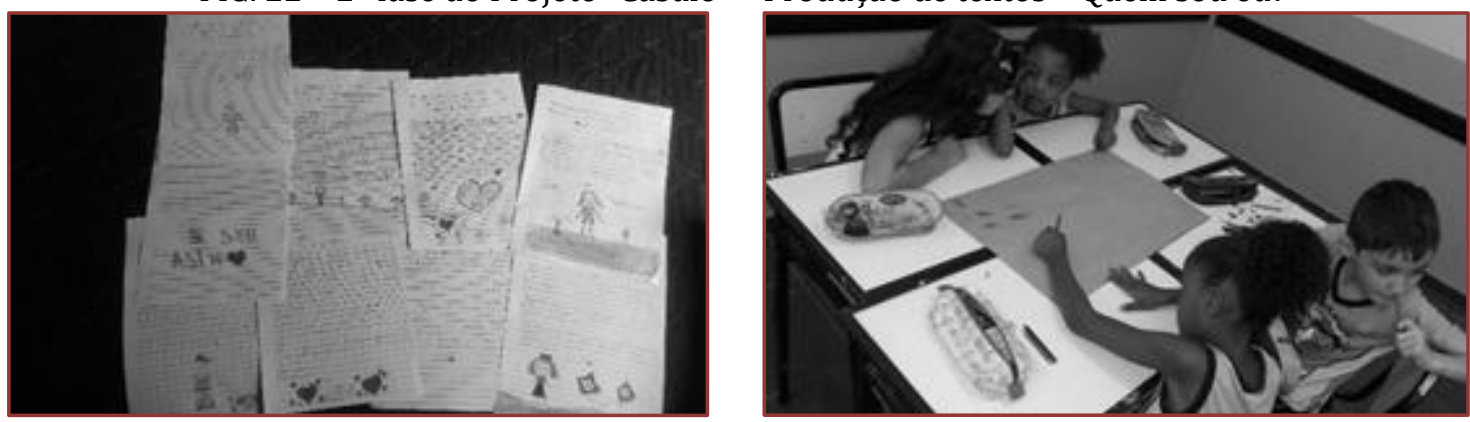

Fonte: Acervo iconográfico da equipe Pibid-UEMG, 2017.

A última fase desse projeto objetivou empoderar as crianças, no sentido de elas lutarem pelos seus sonhos. Para que isso se realizasse, foi contada a história do livro: Ana e o planeta Hamster, de Nicolly Tesh Arruda, de apenas 9 anos, cujo enredo é sobre o valor da amizade. Nelly Novaes Coelho afirma que:

(...) ainda não descobriram que a verdadeira evolução de um povo se faz ao nível da mente, ao nível da consciência de mundo que cada um vai assimilando desde a infância. Ou ainda não descobriram que o caminho essencial para se chegar a esse nível é a palavra. Ou melhor, é a literatura - verdadeiro microcosmo da vida real, transfigurada em arte. (...). É ao livro, à palavra escrita, que atribuímos a maior responsabilidade na formação da consciência de mundo das crianças e dos jovens. (COELHO, 2010, p. 15)

Além de escutarem a narrativa, era intenção mostrar aos alunos que todos eles poderiam ser o que desejassem, inclusive escritores ou ilustradores. Como o livro ainda não havia sido publicado, as bolsistas pibidianas solicitaram aos alunos ilustrarem cada parte da história. Os desenhos que mais representassem a narrativa seriam expostos no dia da culminância do projeto e os três primeiros lugares ganhariam prêmio, entregues pela própria autora mirim.

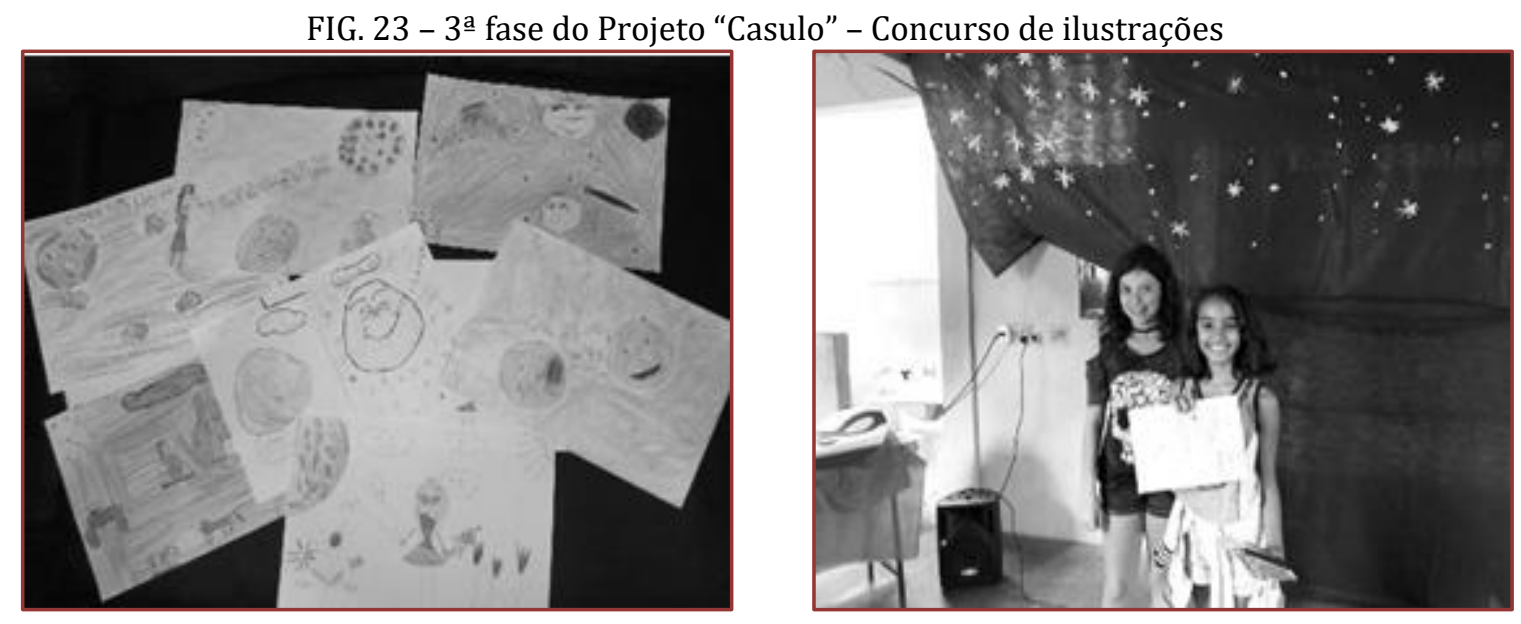

Fonte: Acervo iconográfico da equipe Pibid-UEMG, 2017. 
FIG. 24 - Culminância do Projeto "Casulo" com a participação da escola e família
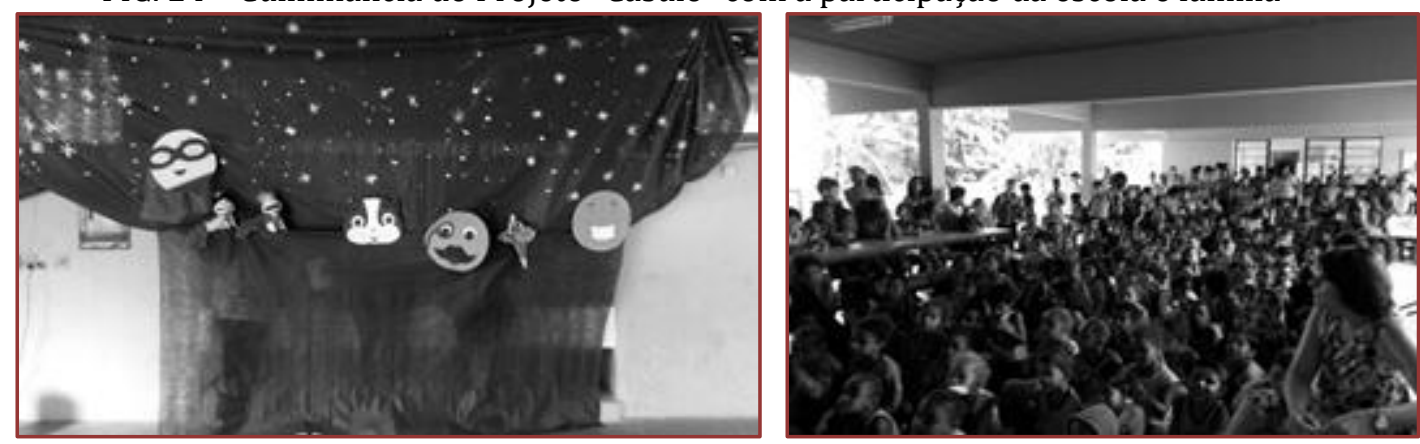

Fonte: Acervo iconográfico da equipe Pibid-UEMG, 2017.

O quarto projeto foi "Diversidade e Literatura: prática lúdica de trabalhar a diferença na escola", criado pelos bolsistas da Escola Municipal Professora Maria da Conceição Monteiro de Resende, utilizando dos seguintes livros literários: Zé Diferente, de Lúcia Pimentel Goes; 0 que os olhos não veem, de Ruth Rocha; Por que você não me aceita assim, coelhinha? de Helme Heine e José Feres Sabino; Flávia e o bolo de chocolate, de Mírian Leitão; O pescador, o anel e o rei, de Bia Bedran e, A velhinha que dava nome às coisas, de Cynthia Rylant. 0 enfoque dos livros se convergiam, principalmente, para as temáticas transversais pluralidade cultural e ética.

Os textos foram trabalhados ora como contações de histórias e ora como rodas de leitura, para que pudessem gerar diálogos e questionamentos entre os alunos sobre a diversidade de pessoas nos mais variados aspectos.

Com relação às rodas de leitura literária, estas são formas de socializar a leitura artística, compartilhandoa entre os participantes não só o ato de ler e compreender o texto em questão, mas sobretudo de ouvir o outro, respeitando sua visão de mundo e experiências que se conectam ao texto lido. Além disso, os componentes das rodas de leitura adquirem novas perspectivas de visão, pois trocam impressões e partilham um pouco de si pela comunicação com os outros.

O professor poderá organizar a roda de leitura literária com sua própria classe, levando seus alunos para o pátio ou a biblioteca. Assim, escolhe-se um livro ou um texto que todos possam ter em mãos, a fim de seguirem a leitura, através do leitor-guia, o professor. Este professor deverá conhecer bem o texto, para que o leia com entonação, ritmo e boa diç̧ão. Vale ressaltar que os textos selecionados para leitura e discussão podem ser dos mais diversos gêneros e subgêneros literários, valorizando o tema de interesse do grupo. Com isso, não é preciso que o objeto de leitura seja necessariamente um livro, mas crônicas, contos, fábulas, lendas, apólogos, parábolas, narrativas populares, poemas, etc.

Conforme Silva (2002), a literatura é um possível caminho para encontrar respostas e criar novas perguntas, e, principalmente, sentir prazer nessa atividade, que poderá instigar o leitor a transformar a sua visão de mundo, sendo agente de sua própria história, o que corrobora com a proposta desta pesquisa:

A literatura, enquanto expressão da vida, tem a capacidade de redimensionar as percepções que o sujeito possui de suas experiências e de seu mundo. Por isso mesmo, a leitura da literatura, pela sua natureza e pela sua força estética, colabora significativamente para com a formação da pessoa, influindo nas suas formas de pensar e de encarar a vida.

(SILVA, 2002, p. 89)

Sabe-se que a escola é um espaço sociocultural, onde as pessoas se relacionam, trazendo cada indivíduo que a compõe experiências vividas, em outros espaços sociais. Portanto, é nessas instituições escolares que a pluralidade cultural de grupos étnicos, sociais ou culturais precisa de ser analisada como matériaprima da aprendizagem. De acordo com o Plano Nacional de Educação em Direitos Humanos, a escola

(...) é um espaço social privilegiado onde se definem a ação institucional pedagógica e a prática e vivência dos direitos humanos. Nas sociedades contemporâneas, a escola é local de estruturação de concepções de mundo e de consciência social, de circulação e de consolidação de valores, de promoção da 
diversidade cultural, da formação para a cidadania, de constituição de sujeitos sociais e de desenvolvimento de práticas pedagógicas. (BRASIL, 2008, p.31)

Do projeto "Diversidade e Literatura: prática lúdica de trabalhar a diferença na escola" surgiram atividades como confecção de cartazes literários, com resumos das narrativas, escritos pelos alunos de 4음 e 5o anos; jogos para a alfabetização, produzidos a partir dos textos artísticos lidos para os alunos do 1o e 2 o anos, como jogo de argola, bingo de letras e palavras, forma palavras e caça-palavras); dramatização do livro: Flávia e o bolo de chocolate, de Mírian Leitão, a fim de desenvolver nos alunos o hábito de ouvir e integrarem-se no auditório; produção de um livro, no formato de um lápis, onde o aluno escreveu a sua autobiografia; além de várias oficinas de literatura africana infantil, com o intuito de os alunos obterem conhecimento e valorizarem a cultura e a história de afrodescendentes.

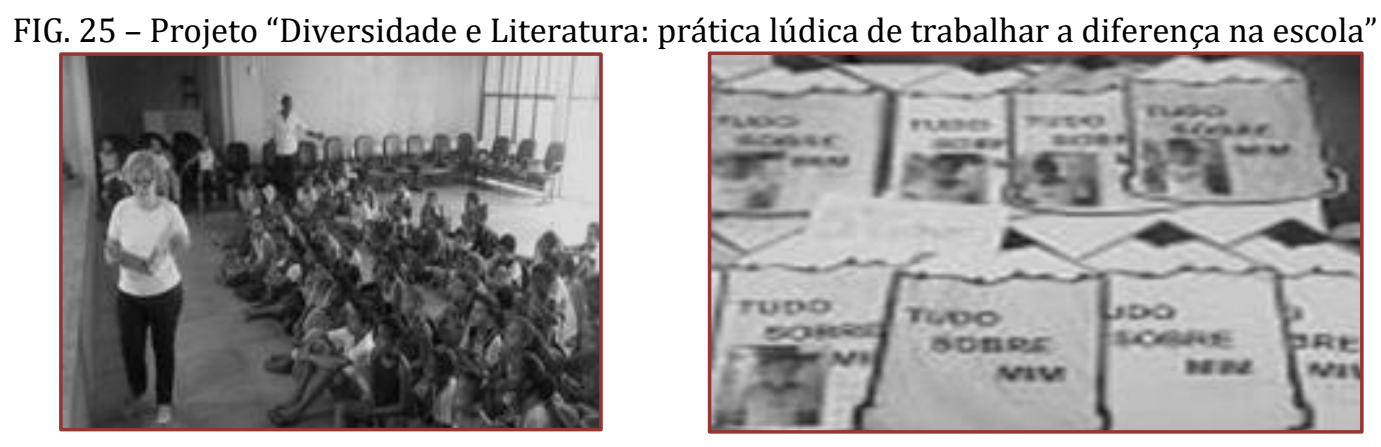

Fonte: Acervo iconográfico da equipe Pibid-UEMG, 2017.

FIG. 26 - Projeto "Diversidade e Literatura: prática lúdica de trabalhar a diferença na escola"
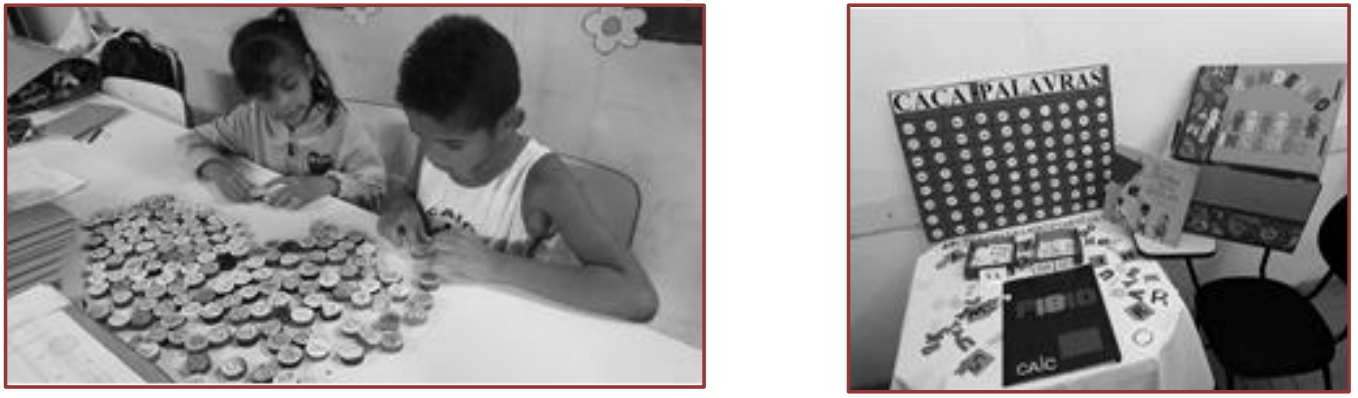

Fonte: Acervo iconográfico da equipe Pibid-UEMG, 2017.

\section{CONSIDERAÇÕES FINAIS}

Com base nos projetos e ações efetivas realizados pelo PIBID-UEMG, subprojeto de Pedagogia de Leopoldina, entre os anos de 2012 e 2017, observou-se como ocorreram repercussões positivas do Programa PIBID na formação inicial dos alunos bolsistas participantes, uma vez que puderam construir uma série de saberes envolvendo teoria e prática, a partir da correlação dos estudos universitários com o desenvolvimento e execução de práticas pedagógicas, no espaço escolar, onde, atuarão, futuramente, como profissionais da educação.

Vale ressaltar que os currículos formadores, por mais sejam os professores universitários atualizados e problematizadores, em suas aulas, dificilmente, possibilitarão aos licenciandos uma reflexão crítica das teorias estudadas sem o exercício dos mesmos nos contextos escolares.

As reuniões semanais com a equipe do PIBID, ocorridas na UEMG-Leopoldina, revelaram a gama de desafios com os quais os bolsistas se defrontaram, na realidade da escola pública, no que se referem às dificuldades de aprendizagem das crianças, ora por questões cognitivas, ora sociais e culturais, ora individuais e ora relacionais. Também perceberam algumas complexidades nos relacionamentos entre profissionais da educação, professor-aluno, e, escola e comunidade. Além disso, observaram como as situações burocráticas e administrativas podem interferir nas ações pedagógicas do cotidiano escolar. Tais percepções, fizeram com que todos pudessem reflexionar, conjuntamente, sobre a postura do professor 
com o educando e colegas de trabalho, bem como o cuidado para com a formação continuada e a inovação das metodologias de ensino.

Diante das diagnoses realizadas com os alunos, no início do ano, nas escolas conveniadas, observou-se que o maior desafio de aprendizagem das crianças originava-se da dificuldade de desenvolver os níveis de leitura: algumas não decodificavam os signos linguísticos, outras decodificavam, mas não compreendiam o que liam, e, ainda outras, compreendiam, mas só conseguiam realizar uma leitura superficial, sem ler entrelinhas do texto ou fazer inferências.

Nessa perspectiva, os bolsistas, sob a orientação de seus supervisores, produziram uma série de ações e projetos pedagógicos, entre 2012 e 2017, inserindo a literatura como a mola propulsora para envolver os alunos em atividades de oralidade, leitura e escrita. Escolheu-se a literatura pelos seus aspectos lúdico, interdisciplinar e provocativo às reflexões dos temas transversais.

Observou-se que no decorrer de cada ano de execução da equipe PIBID-UEMG com a pedagogia de leitura literária, nas escolas conveniadas, novas maneiras de pensá-la e executá-la foram ocorrendo, configurando, assim, um novo cenário de aprendizagem das crianças, que foram tomando gosto pela leitura, aprofundando nas análises textuais e produzindo melhor seus textos.

A desinibição foi outro fator a ser ressaltado, pois com as atividades de reconto das histórias, de rodas de conversas, de exploração dos textos, mediante às contações de histórias, percebeu-se que os estudantes se sentiram mais autoconfiantes e motivados a participarem de todas as propostas solicitadas pelos bolsistas.

As rodas de leitura, envolvendo a transversalidade temática, permitiram-lhes associar o texto literário à vida real, refletindo sobre as complexidades humanas, repensando comportamentos, aprendendo a ouvir e respeitar as abordagens dos colegas, redimensionando, portanto, a visão de mundo de todos os leitores participantes.

Com um repertório mais vasto, em razão de uma variedade de assuntos entrelaçados a inúmeras áreas do conhecimento, os estudantes apropriaram-se de informações, ideias, vocabulário, conhecimentos linguísticos, teorias literárias e valores humanos, o que evidenciou o desenvolvimento deles nas habilidades da comunicação verbal oral e escrita.

A aproximação da família e da comunidade escolar no desenvolvimento e culminância dos projetos proporcionaram às crianças a elevação da autoestima e o sentimento de empoderamento frente aos seus sonhos.

As metodologias de ensino que envolveram o aprender brincando, apresentadas pelos bolsistas, com ênfase na afetividade e no bom relacionamento com o educando, despertaram em alguns docentes atuantes um novo modo de ensinar.

A partir dos fatos apresentados, mensura-se, portanto, que a implementação do Programa PIBID, em Leopoldina, através do subprojeto de Pedagogia da UEMG, apostou na literatura infantil como ponto de partida, para incentivar a oralidade e a leitura às crianças. Em trânsito à execução dos projetos, promoveu a travessia da compreensão de textos superficial à mais aprofundada; da escrita desorganizada à mais coesa e coerente. Nessa perspectiva e em tantas outras, a literatura infantil é uma via de mão dupla, que deve ser investigada pelos educadores e pesquisadores, a fim de que novas histórias de aprendizagem possam ser compartilhadas.

\section{REFERÊNCIAS}

[1] ABRAMOVICH, F. Literatura Infantil: Gostosuras e Bobices. São Paulo: Scipione, 1995. p. 17.

[2] ALLIENDE, F; CONDEMARÍN, M. Trad. Ernani Rosa. A leitura: teoria, avaliação e desenvolvimento. 8. ed. Porto Alegre: Artmed, 2005. p. 7.

[3] BARTHES, R. Aula. São Paulo: Cultrix, 2013.107 p.

[4] BRASIL. Comitê Nacional de Educação em Direitos Humanos. Plano Nacional de Educação em Direitos Humanos. Brasília: Secretaria Especial de Direitos Humanos, Ministério da Educação, Ministério da Justiça, UNESCO, 2008. p. 31.

Ministério da Educação, Secretaria de Educação Fundamental. Parâmetros Curriculares Nacionais: Língua Portuguesa. Brasília: MEC, 1997. p. 27-28.

Secretaria de Educação Fundamental ( 1997 a). Parâmetros Curriculares Nacionais: introdução aos parâmetros curriculares nacionais (v.1).Brasília: MEC/SEF. p. 15. 
[5] BUSATTO, C. $A$ arte de contar histórias no século XXI. Petrópolis: Editora Vozes, 2007. p. 58.

[6] COELHO, N.N. Literatura infantil: teoria, análise e didática. 11. ed. São Paulo: Moderna, 2010. p. 28-30.

[7] COLOMER, T.; CAMPS, A. Ensinar a ler, ensinar a compreender. Porto Alegre: Artmed, 2002. p. 90.

[8] COSSON, R. Letramento Literário: teoria e pratica. 2o ed. São Paulo: Contexto, 2014. p. 66.

[9] DINORAH, M. O livro infantil e a formação do leitor. Petrópolis, RJ: Vozes, 1996. p. 28.

[10] LAJOLO, M. A leitura literária na escola. In: Do mundo da leitura para a leitura do mundo. São Paulo: Ática, 2007. $111 \mathrm{p}$.

[11] NÓVOA, A. Formação de professores e trabalho pedagógico. Lisboa: Educa. 2002.

[12] PIBID: construindo saberes e práticas docentes. FRANÇA, C. S. F. et al. (Org.). Barbacena: EdUEMG, 2014.147 p.

[13] RELATÓRIO semestral da Equipe Pibid-UEMG-Leopoldina. 2012.

___ Anual da Equipe Pibid-UEMG-Leopoldina. 2013.

__ Anual da Equipe Pibid-UEMG-Leopoldina. 2014.

___ Anual da Equipe Pibid-UEMG-Leopoldina. 2015.

___ Anual da Equipe Pibid-UEMG-Leopoldina. 2016.

___ Anual da Equipe Pibid-UEMG-Leopoldina. 2017.

[14] SILVA, E. T. Elementos da Pedagogia de Leitura. 3. ed. São Paulo: Martins Fontes, 2002. p. 24.

[15] SILVA, J. M. Docentes na Educação Básica: novas demandas, novas competências. Revista, 1999. p. 68.

[16] SILVA, T. T. A produção social da identidade e da diferença. In:__ (org. e trad.). Identidade e diferença: a perspectiva dos estudos culturais. Petrópolis: Vozes, 2000. p. 50.

Documentos de Identidade: uma introdução às teorias do currículo. 3 ed. Belo Horizonte: Autêntica, 2009. 153 p.

[17] SOARES, M. Letramento: um tema em três gêneros. 3ª ed. Belo Horizonte: Autêntica, 2009. 128 p.

[18] UEMG: unidade na diversidade. LAMBERT, M. M. et al.YT (org.). Belo Horizonte: EdUEMG, 2017. 81 p.

[19] VYGOTSKY, L. S. A formação social da mente. 6. ed. São Paulo: Martins Fontes, 1998. p. 130.

[20] VILLARDI, R. Ensinando a gostar de ler: formando leitores para a vida inteira. Rio de Janeiro: Dunya Qualitymark, 1997. p. 2. 


\section{Capítulo 14}

Formação de professores e Educação do Campo: Uma análise na Escola Municipal Unidade Escolar XXXIV Miraselva (Apodi-RN)

Ana Claudia de Andrade Costa

Kyara Maria de Almeida Vieira

Resumo: A Educação do Campo vem sendo bastante defendida pelos movimentos sociais há algumas décadas, a exemplo de um desses movimentos sociais podemos citar o Movimento dos trabalhadores e trabalhadoras Sem Terra (MST), que luta por uma educação que atenda os povos do campo e que contextualize a realidade das pessoas inseridas nessas localidades. Nessa perspectiva o presente trabalho tem como objetivo investigar como está se constituindo a formação dos/as educadores/as das escolas do campo e como refletem no processo de ensino e aprendizagem dos/as estudantes numa escola do Oeste Potiguar. Para o delineamento desse estudo, nosso trajeto metodológico foi composto por: A) revisão bibliográfica no qual buscamos dialogar com autores/as que versam sobre o tema em questão como: Cunha (2005), Reis (2011), Barauna (2009); B) análise de documentos da Escola Municipal Unidade Escolar XXXIV Miraselva (ApodiRN), como caderno de planejamento; C) pesquisa de campo com realização de entrevista semiestruturada com a única docente da escola que leciona na educação infantil em uma turma multisseriada e observações de aulas.

Palavras chave: Educação do Campo. Formação Docente. Ensino. Aprendizagem. 


\section{INTRODUÇÃO}

Podemos considerar que o processo de ensino aprendizagem é algo que exige uma assídua discussão e planejamento. Aqui trataremos de uma escola do campo, e do princípio de que esse ensino e aprendizagem deve partir da realidade dos/as educandos/as, o meio em que camponeses/as vivem.

A pesquisa foi desenvolvida na Unidade Escolar XXXIV Miraselva, localizada no Projeto de Assentamento São Manoel, mas que é mais conhecido como comunidade Poço de Tilon, na zona rural da cidade de ApodiRN. A comunidade historicamente se originou de uma fazenda, denominada Fazenda Miraselva. Com o passar dos anos, a comunidade ganhou seu nome devido a um poço que existia na fazenda, que pertencia ao Senhor Tilon Gurgel do Amaral, um coronel que detinha em sua posse a terra e a água, figura pública de grande influência na região. Em virtude disso a comunidade ficou conhecida com o referido nome ${ }^{5}$.

O referido assentamento se localiza na zona rural do município de Apodi, no estado do Rio Grande do Norte, localizado na microrregião da Chapada do Apodi, na mesorregião do Oeste Potiguar e no Polo Costa Branca. De acordo com a estimativa realizada pelo IBGE (Instituto Brasileiro de Geografia e Estatística) em 2017, sua população é de 36.323 habitantes; área territorial de 1. 602, $477 \mathrm{~km}$. Os primeiros habitantes do Apodi foram os índios Tapuias Paiacus, pertencentes ao grupo étnico cultural Tarairiú. Abaixo estão os mapas da região mencionada no estudo:
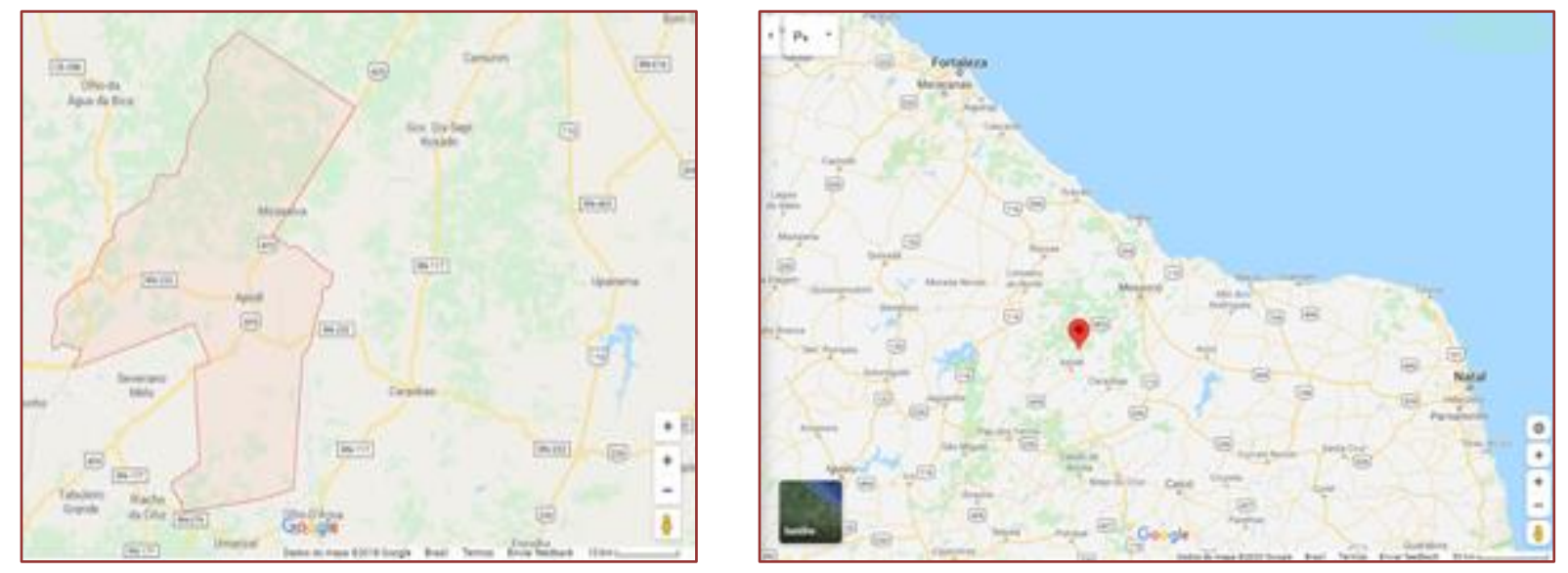

Fonte:Google Maps

Após definido o recorte espacial de nossa pesquisa, faz-necessário ratificar que nos propomos a investigar como se dá o processo de formação da docente, se a mesma tem algum auxílio ou algum tipo de formação continuada que contextualize com a realidade dos/as educando/as. Pois como pontua Caldart (2011, p.137) “(...) A educação do campo não cabe em uma escola”, expande, vai além, afeta toda uma comunidade ou várias comunidades. A educação do campo pode (trans) formar várias vidas desde que seja um processo que envolva comprometimento, sensibilidade e responsabilidade, exigindo uma articulação entre a formação centrada na razão técnica, nas experiências e nos saberes. Conforme destaca Arroyo (2007, p.158): “(...) 0 histórico brasileiro mostra que não há uma tradição nem na formulação de políticas públicas, nem no pensamento e na prática de formação de profissionais da educação que focalize a educação do campo e a formação de educadores do campo como preocupação legítima".

Saber como se dá a formação desses/as professores/as que trabalham nessas localidades se faz necessário para podermos observar o processo de ensino e aprendizagem dos/as mesmos/as, pois sabemos que o acesso à educação no campo ainda é uma luta regida pela busca de direitos, já a educação foi historicamente negada aos sujeitos que vivem e atuam nessas localidades.

\footnotetext{
5 Poço Tilon é uma comunidade rural localizada no município de Apodi-RN, às margens da BR 405. Um sítio pequeno, em que 40\% de sua população é emigrante, vindos do Estado da Paraíba no ano de 1974; até esses anos o Poço Tilon tinha poucos habitantes. Hoje sua principal fonte de economia deriva-se da agricultura e da extração de pedra. Segundo um dos moradores mais antigos do lugar, Seu Edilson, a comunidade surgiu porque o acesso a água vinha de um poço de uma fazenda cujo proprietário chamava-se Seu Tilon. 0 mesmo deixava a população abastecer suas casas com a água do poço, a partir daí todos começaram a chamar o local de Poço de Tilon (COSTA, 2018, p. 23).
} 


\section{METODOLOGIA}

Metodologicamente o trabalho foi construído a partir de revisão bibliográfica, observação de aulas, caderno de planejamento e entrevista com a professora Helena ${ }^{6}$, única docente da escola lócus da pesquisa. Nessa perspectiva o objetivo principal foi buscar identificar como se dá o processo de formação de professores/as que lecionam no campo, além de lançar um olhar a respeito do procedimento de ensino e aprendizagem dos mesmos. É importante frisar que as aulas funcionam em um prédio cedido pela comunidade, com uma turma multisseriada que atende do $1^{\mathrm{O}}$ ao $5^{\mathrm{o}}$ ano do ensino fundamental I, composta por 20 estudantes.

Os/as professores/as que atuam nas escolas de comunidades rurais apresentam uma deficiência em sua formação sobre as questões de educação do campo tendo em vista a falta de políticas públicas de formação continuada para esses/as profissionais. Os programas de formação são pensados dentro do modelo de escolarização formal e urbanocêntrica. Em sua maioria os/as professores/as vêm de outra realidade. Destacamos que a ausência de um corpo de profissionais que vivam junto às comunidades rurais, que sejam oriundos dessas localidades faz toda diferença na contextualização da realidade local. Mas, para além disso é necessária a formação continuada para os que já atuam e propostas de formação contextualizada para os que virão a atuar nessas localidades.

Por isso a necessidade de buscar conhecer como está se desenvolvendo essa educação através da pesquisa. Segundo Piena (2009, p. 167) "O ato de pesquisar traz em si a necessidade do diálogo com a realidade a qual pretende investigar e com o diferente, um diálogo dotado de crítica, canalizador de momentos criativos". 0 estudo aqui apresentado possui aspectos que relaciona a observação da teoria e da prática, que será apresentado no tópico seguinte.

\section{RESULTADOS E DISCUSSÕES}

Os saberes dos homens e das mulheres do campo são múltiplos, construídos diariamente a partir do seu cotidiano, este que deve ser evidenciado no processo de formação educacional nas escolas do campo. 0 processo de desenvolvimento em Educação do Campo, vem sendo pensado para desenvolver um projeto político pedagógico que consiga agregar os direitos educacionais da população camponesa. 0 artigo 26 da LDB/96 destaca que os currículos podem se apoiar no currículo da base nacional comum, porém deve ser inserido as características regionais e locais da sociedade, da cultura, e da economia. De acordo com Rodrigo e Bonfim (2017, p. 1374):

A LDB/96 foi um avanço com relação à educação do campo, pois delineou as principais ideias que norteiam esse tipo de educação, determinando legalmente como deve ser a metodologia, o currículo, a organização das escolas situadas no campo, bem como questões envolvendo o calendário escolar que no campo diverge do calendário das escolas do meio urbano, por conta de situações climáticas e fases do ciclo agrícola.

Dentro desse contexto destacamos que o campo está vivo, isso é perceptível através da sua cultura, dos seus saberes e da luta por direitos como: acesso à terra, à agua, às florestas, e também à educação. A educação do campo precisa ser incorporada no currículo escolar como um instrumento de fortalecimento e valorização das identidades dos sujeitos campesinos, a partir da sua importância dentro da sociedade na qual se inserem.

A Constituição Federal de 1988, no artigo 6o destaca: "São direitos sociais a educação, a saúde, o trabalho, a moradia, o lazer, a segurança" (BRASIL, 1988). Conforme está expresso na Constituição é direito da população campesina o acesso a uma educação que atenda suas especificidades, e que seja equiparada aos benefícios e à qualidade pretendida e exigida para a educação do contexto urbano.

\footnotetext{
${ }^{6}$ Vale frisar que Helena é o pseudônimo que escolhemos para identificar a professora. Mesmo que ela tenha assinado o Termo de Consentimento Livre Esclarecido para a realização da pesquisa, decidimos por preservar a identidade da mesma visando a ética da pesquisa. Helena é professora polivalente há 12 anos da Unidade Escolar XXXIV Miraselva, formada em Pedagogia e possui especialização em psicopedagogia. A mesma reside na comunidade em que leciona e afirma ter interesse em fazer uma pós-graduação em Educação do Campo para poder proporcionar um melhor ensino para seus/as educandos.
} 
Nesse sentido faz-se necessário situar os/as leitores/as o histórico da educação do campo, esta que surge em 1997 quando o MST promove o I Encontro Nacional de Educadoras e Educadores da Reforma Agrária (ENERA). 0 encontro contribuiu para a mobilização e união de entidades sociais e instituições de ensino, em torno de reflexões sobre temáticas relacionadas ao campo. Após isso, o movimento por uma educação do campo ganhou força com a criação da Articulação Nacional por uma Educação do Campo, ocorrida em 1998. A partir desta passou-se a promover e também a gerir ações conjuntas pela escolarização dos povos do campo em nível nacional.

De acordo com Kolling, Nery e Molina (1999 apud BARAÚNA, 2009) a I Conferência por uma Educação Básica do Campo foi realizada em 1998 na cidade de Luziânia, em Goiás, e teve como expressão maior o desejo de favorecer o debate acerca das condições de vida da população do campo.A partir das discussões da I Conferência foi criado um texto base que traça o perfil da educação a ser desenvolvida no campo, como apontamos a seguir:

(...) o propósito é conceber uma educação básica do campo, voltada aos interesses e ao desenvolvimento sociocultural e econômico dos povos que habitam e trabalham no campo, atendendo às suas diferenças históricas e culturais para que vivam com dignidade e para que, organizados, resistam contra a exclusão, ou seja, este do campo tem o sentido do pluralismo das ideias e das concepções pedagógicas (KOLLING; NERY; MOLINA, 1999 apud BARAÚNA, 2009 p. 292).

A partir desses encontros houve a construção das Diretrizes Operacionais para a Educação Básica em Escolas do Campo, que pressupõe que haja de fato uma educação do campo para os povos do campo, sendo necessário que houvesse formação docente voltada aos interesses das populações do campo.

Percebe-se então que a formação docente exige do/a professor/a identificação com a proposta de educação nos moldes divulgados, e não como uma adaptação do que acontece nas escolas urbanas, de modo a atender uma formação docente que contemple a nova compreensão de educação do campo, e não apenas como uma adaptação do urbano. Baraúna (2009, p. 302) salienta que “(...) o campo necessita de um projeto educacional diferenciado, bem como de profissionais que atuem concretamente nessa realidade, não apenas dando boas aulas, mas, elaborando projetos que caracterizam a realidade e a identidade rural".

A educação do campo necessita de formação docente que contemple os anseios das populações do campo nos âmbitos filosóficos, epistemológicos e políticos. Não é apenas uma questão de técnicas e metodologias de ensino, são necessários profissionais comprometidos politicamente com as questões relativas ao campo.

Percebe-se que para a formação dos professores/as que trabalham em localidades situadas no campo espera-se dos/as profissionais uma perspectiva de contextualização. Segundo Baraúna (2009, p. 303),

A educação do campo necessita de muito mais do que métodos e técnicas de ensino, precisa de profissionais que estejam comprometidos politicamente com as questões relativas ao meio rural e compete às universidades oportunizarem momentos de reflexão e construção de projetos diferenciados.

Desta feita, a Educação do Campo deve ser compreendida em seu contexto político para que haja de fato a garantia de educação de qualidade no campo. A justificativa parte do pressuposto que a Educação do Campo deve ser entendida por uma educação que atenda os povos do campo e que o processo de ensino e aprendizagem seja contextualizado com a realidade dos sujeitos, para isso a formação docente é imprescindível para corroborar numa aprendizagem qualificada e significativa para os/as estudantes.

\section{OBSERVAÇÃO DAS AULAS}

Inicialmente, fizemos contato com a professora, dialogamos a respeito da pesquisa e obtivemos a autorização da mesma para observar suas aulas. Foram cinco aulas observadas. No primeiro dia, a professora nos apresentou para a turma e ficamos no canto da sala, observando; olhares atentos, curiosos, inquietos nos reparavam. No segundo dia já estavam mais familiarizados, a aula fluiu normalmente e assim ocorreu nos dias seguintes. Chegávamos 13 horas e saíamos as 17 horas. Como afirma Reis (2011, p. 12) 
As observações de aulas podem permite aceder, entre outros aspectos, ás estratégias e metodologias de ensino utilizadas, ás atividades realizadas, ao currículo implementado e ás interações estabelecidas ente professores e alunos no contexto institucional; a observação de aulas assume diferentes tipologias informais ou formais.

Esse método nos permite observar como se dá o desenvolvimento da aula, como é a metodologia das/os professores/as, e a interação da comunidade escolar como um todo.

Durante a observação das aulas, notamos que o maior desafio da professora era o tempo: a mesma não conseguia auxiliar todos os/as estudantes de todas as séries no curto espaço de tempo, prejudicando assim tanto o desenvolvimento da aula, quanto a qualidade do ensino. Outro ponto observado foi a falta de recurso, de materiais didáticos para a mesma desenvolver suas atividades.

Foi observado ainda que as aulas da professora, embora não dialogasse com o que se espera que seja trabalhado na educação do campo (que conteúdos dialoguem com a realidades local dos/as estudantes), a mesma buscava de alguma maneira fazer relação através de exemplos dados durante as explicações do conteúdo. Assim, notamos que os planejamentos das aulas não atendem ás especificidades dos povos do campo e tem como base o que se discute nas escolas urbanas.

\section{ANÁLISE DO CADERNO DE PLANEJAMENTO}

Nessa seção será apresentada a análise documental dos cadernos de planejamento. Em relação à escrita do caderno de planejamento, afirma Cunha (2005, p. 81): “(...) eles são resultados tanto da necessidade de testemunhar o vivido como de imposições de normas institucionais, além de guardar vestígios de uma educação escolarizada".

No caderno de Planejamento analisado, primeiramente temos a ROTINA. Nesse espaço do caderno de planejamento são evidenciadas as disciplinas:

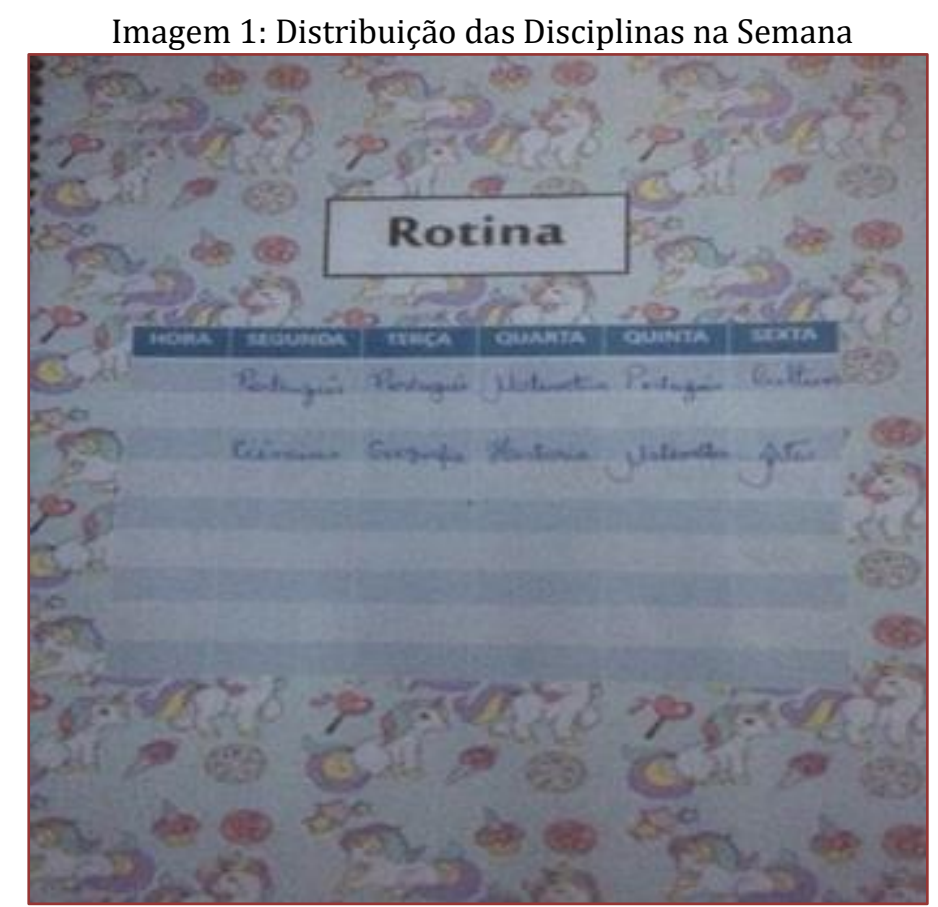

Fonte: Arquivo Pessoal 
Trata-se de um espaço destinado para a distribuição de disciplinas que serão oferecidas para estudantes no semestre. Como exemplo, na Segunda Feira é o dia em que os estudantes têm a disciplina de Português e Ciências. É perceptível que essas aulas não têm embasamento das discussões da pedagogia da alternância, que segundo Calvó (1999, p. 17) é um “conjunto dos períodos formativos que se repartem entre o meio sócio profissional (seja na própria família ou na empresa) e a escola. Isto sempre dentro de uma interação educativa escola-meio". Atividades de ensino e aprendizagem são divididas em tempo comunidade e tempo escola, momentos estes que estudantes precisam articular os conhecimentos e experiências vividas em sua comunidade com o que é partilhado na escola, e vice-versa. Como podemos perceber as aulas ocorrem somente no tempo escola.

Em segundo, temos o PLANO DE AULA. Nesse espaço são evidenciados a data que será ministrada a aula, o componente curricular, o tema, conteúdo que será trabalho, o desenvolvimento da aula, as tarefas de casa para cada ano (pois se tratam de salas multisseriadas) e a avaliação.

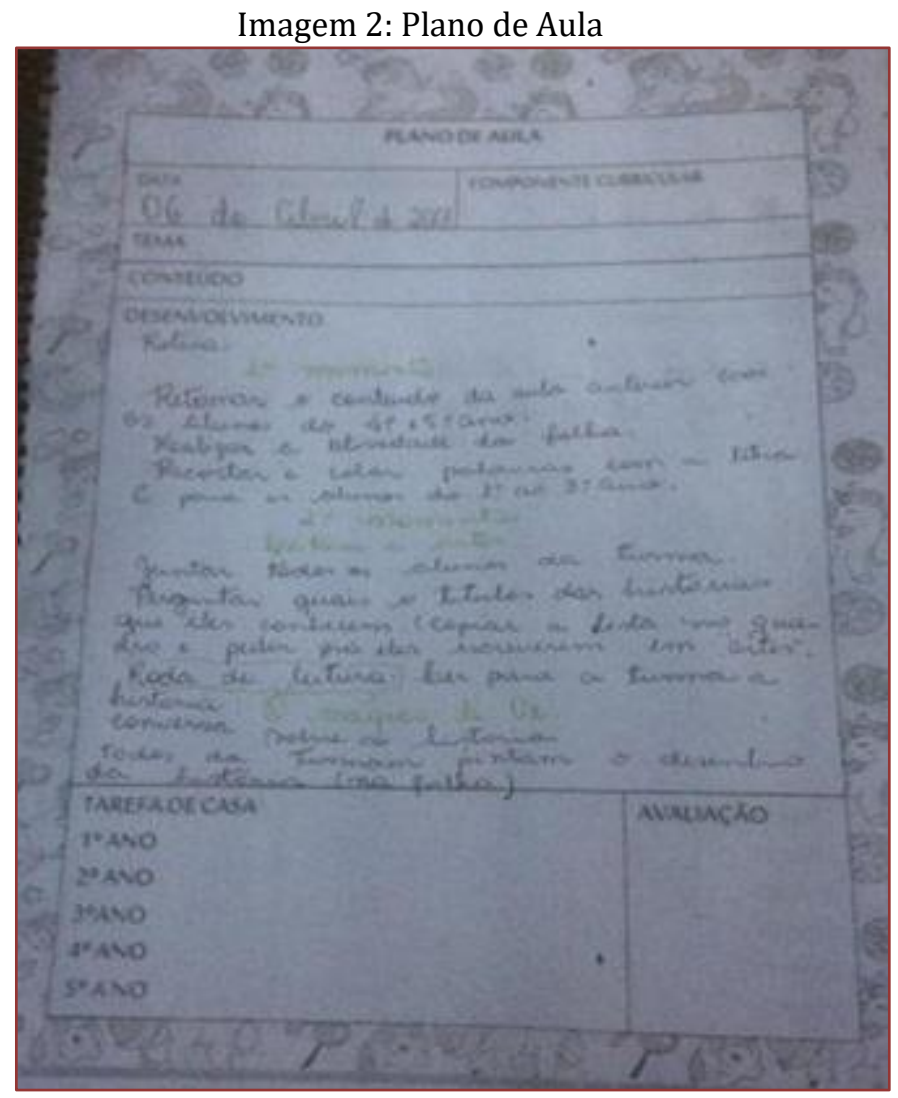

Fonte: Arquivo Pessoal

Como atividade tem a leitura em forma de roda de conversa de um livro chamado Magico de Oz (1900), obra que baseará o filme estadunidense produzido nos anos de 1939. Embora reconheçamos a importância do contato com o conhecimento global, a atividade não enfatiza saberes do campo, portanto, é perceptível que não ocorre uma contextualização com a realidade dos/as estudantes. Não estamos assim defendendo que a obra não possa ser trabalhada, ou que os/as estudantes não possam ter contato com esse tipo de leitura. Mas, o interessante seria que após a leitura do livro tivesse alguma atividade pedagógica que pudesse relacionar com o contexto dos/as estudantes. Desta forma, seria possível fomentar um saber significativo e crítico sobre o conteúdo trabalhado. 


\section{CONVERSANDO COM A PROFESSORA: ALGUMAS PERCEPÇÕES}

Para além das fontes de pesquisa documentais, nossa pesquisa também fez o uso de fontes de história oral, através da realização de entrevistas. Segundo Alberti (2005, p. 155):

A história oral é uma metodologia de pesquisa e de constituição de fontes para o estudo da história contemporânea. Ela consiste na realização de entrevistas [...] com indivíduos que participaram de, ou testemunharam, acontecimentos e conjunturas do passado e do presente.

A entrevista que realizamos com a professora Helena nos motivou a consultarmos a Lei de Diretrizes e Bases da Educação Nacional 9.394/96, e observamos alguns avanços em relação à educação do campo, conforme expresso no artigo 26. A própria lei já pode ser considerada uma conquista, porém isso não é garantia de que de fato esteja sendo efetivada essa educação. 0 Artigo 28 afirma que:

(...) os sistemas de ensino promoverão as adaptações necessárias a sua adequação às peculiaridades da vida rural e de cada região, especificamente: I conteúdos curriculares e metodologias apropriadas às reais necessidades e interesses dos alunos da zona rural; II - organização escolar própria, incluindo adequação do calendário escolar às fases do ciclo agrícola e às condições climáticas; III - adequação à natureza do trabalho na zona rural (BRASIL, 1996).

No entanto, o que foi possível observar com a pesquisa é que nenhuma dessas exigências expressas na lei é atendida. Ao conversarmos com a professora Helena, a mesma salienta que o livro didático utilizado é da Coleção Girassol (FTD) ${ }^{7}$, que é voltado para se trabalhar com as especificidades do campo. Perguntamos se era ofertado algum tipo de formação continuada para que pudesse facilitar o diálogo com os preceitos da educação do campo, ela nos respondeu:

Não, não temos nem um tipo de formação continuada voltada para trabalhar as demandas do campo. A formação continuada que participei foi o Pacto Nacional pela Alfabetização na Idade Certa (PNAIC) (HELENA, 2018).

Mesmo sem que haja oferta, por parte da secretaria de educação, de uma formação continuada, professora Helena nos disse: “(...) embora eu não participe de formação continuada, estou sempre buscando relacionar alguns exemplos com a realidade dos meus alunos e alunas". Observamos a partir de sua fala que, mesmo diante da falta de formação e material didático, a mesma afirmou que busca contextualizar conteúdos e vivências de estudantes. Mesmo assim, esses 'esforços' individuais de Helena não são suficientes para resolver as demandas de sua turma. Sobre isto, a professora reitera algumas de suas angústias:

Encontro grande dificuldade de trabalhar na escola por falta de recursos e por se tratar de uma sala multisseriada, o rendimento dos alunos cai, porque é uma grande diversidade que temos na sala de aula e trabalhar com cada série um planejamento diferente, exige muito de mim (HELENA, 2018).

Nesse contexto, podemos destacar a partir do que foi identificado que trabalhar com classe multisseriada é um desafio para os/as docentes, pois em muitos dos casos (e aqui nesse caso específico) durante a formação, os/as educadores não são preparados/as para atuarem com essas especificidades as quais exige uma maior dinâmica de organização e tempo dos/as mesmos/as. Se pensarmos que as salas multisseriadas podem permitir certa socialização, quer na produção/partilha de conhecimentos, quer na veiculação das crenças e valores, proporcionando uma interação social entre os sujeitos, a falta de planejamento, a ausência de propostas pedagógicas e de apoio geram uma exorbitante demanda para ser atendida apenas por uma professora.

\footnotetext{
${ }^{7}$ A Coleção Girassol (Editora FTD), está entre os livros didáticos voltados especificamente para as escolas do campo. Esses livros passaram a ser produzidos e enviados às escolas municipais e estaduais de educação básica (1ํo ao 5ํano) a partir da publicação da Resolução CD/FNDE № 40, de 26 de julho de 2011, que dispunha sobre o Programa Nacional do Livro Didático do Campo (PNLD Campo) para as escolas pertencentes a áreas rurais. A Resolução indicava o Fundo Nacional de Desenvolvimento da Educação (FNDE) e a Secretaria de Educação Continuada, Alfabetização, Diversidade e Inclusão (Secadi) como os responsáveis pela elaboração dos editais de convocação, avaliação e seleção dos livros, e teve sua primeira edição em 2013, e a segunda em 2016. Em 2018 se deu o encerramento do PNLD campo, por meio do Informe no 07/2018 - COARE/FNDE (https://www.fnde.gov.br/index.php/programas/programas-dolivro/pnld/informe-pnld). Quanto a Secretaria de Educação Continuada, Alfabetização, Diversidade e Inclusão (Secadi), foi extinta por meio do Decreto no 9.465, de 2 de janeiro de 2019 (http://www.in.gov.br/materia//asset_publisher/Kujrw0TZC2Mb/content/id/57633286).
} 
De fato, a realidade da maioria das escolas multisseriadas, revela grandes desafios para que sejam cumpridos os preceitos constitucionais e os marcos legais operacionais anunciados nas legislações específicas, que definem os parâmetros de qualidade do ensino público conquistados com as lutas dos movimentos sociais populares do campo (HAGE, 2010, p.26).

Podemos dizer que, nas circunstâncias observada no campo de pesquisa, essa não é a melhor alternativa para os/as estudantes e para a comunidade. Esse método se apresenta como sendo uma imposição do Estado para suprir uma demanda sem considerar as condições de trabalho docente e nem os processos de ensino e aprendizagem. As salas multisseriadas são impostas pela gestão pública para qual não "interessa" articular um projeto pedagógico que responda os direitos estabelecidos na lei. Isso interfere no processo de ensino e aprendizagem e no exercício da docência.

\section{CONCLUSÃO}

Buscando responder o que nos propomos investigar no primeiro objetivo acerca da formação dos/as educadores/as das escolas do campo, podemos dizer a partir do caso em estudo que a formação docente não tem uma base nos princípios da Educação do Campo, na perspectiva da contextualização e na pedagogia da alternância; que não existe um programa ou política pública de formação continuada para trabalhar especificamente as questões relacionadas às comunidades rurais e à Educação do Campo.

Quanto ao segundo objetivo, que nos propomos analisar como a formação dos/as educadores/as do campo se relaciona com o processo de ensino e aprendizagem dos/as estudantes, destacamos que os resultados da pesquisa apontam que a falta de formação, a disposição precária de tempo, a falta de material didático, associados a obrigatoriedade de ser uma sala multisseriada, são fatores que dificultam e levam à precarização do trabalho da professora, e que, portanto, fragilizam as experiências de ensino e aprendizagem de estudantes. Tais condições propiciam a reprodução do modelo de ensino e conteúdo das escolas urbanas, mesmo que utilize um livro didático do PNLD Campo.

Por fim, salientamos que nossa pesquisa nos permitiu identificar que existe um grande fosso entre o que está assegurado nos documentos legais que tratam da Educação do Campo, e o que de fato está sendo efetivado na prática. Isso nos faz perceber que, apesar das conquistas desde 1997 quando ocorreu o I Encontro Nacional de Educadoras e Educadores da Reforma Agrária (ENERA), vivemos uma avassaladora perda de direitos para os povos do campo, e por isso temos uma grande luta para 1) evitar o fechamento das escolas do campo, 2) frear a massificação das escolas multisseriadas, sem condições de trabalho e sem formação específica, 3) garantir a realização de concursos públicos federais, estaduais e municipais que incluam em seus editais vagas com o perfil de formação em licenciaturas interdisciplinares em Educação do Campo, 4) assegurar a formação continuada para docentes que já atuam, e formação contextualizada para docentes que irão atuar nas escolas do campo. Dessa maneira as escolas do campo não apenas receberão profissionais qualificados para trabalhar as especificidades dos povos campesinos, mas também serão partícipes da transformação das pessoas do campo através da educação de qualidade e gratuita.

\section{REFERÊNCIAS}

[1] ALBERTI, Verena. Fontes Orais. História dentro da História. In: PINSKY, Carla Bassanezi (org.). Fontes Orais. São Paulo: Contexto, 2005.

[2] ARROYO, M. G. Políticas de formação de educadores(as) do campo. Caderno Cedes, Campinas, vol. 27, n. 72, p. 157-176, maio/ago. 2007. Disponível em: http://www.scielo.br/pdf/ccedes/v27n72/a04v2772.pdf. Acesso em: 15 de maio de 2020 .

[3] BARAÚNA, Rosemeire Silva. Formação de professores e educação do campo: análise de uma proposta de formação superior e repercussões em um município baiano. In: CUNHA, MC, org. Gestão Educacional nos Municípios: entraves e perspectivas, Salvador: EDUFBA, 2009. 366 p. ISBN 978-85-232-0586-7. Available from SciELO Books. http://books.sicelo.org

[4] BRASIL. Decreto no 9.465, de 2 de janeiro de 2019. Aprova a Estrutura Regimental e o Quadro Demonstrativo dos Cargos em Comissão e das Funções de Confiança do Ministério da Educação, remaneja cargos em comissão e funções de confiança e transforma cargos em comissão do Grupo-Direção e Assessoramento Superiores DAS e Funções Comissionadas do Poder Executivo - FCPE. 2019. Disponível em: http://www.in.gov.br/materia//asset_publisher/Kujrw0TZC2Mb/content/id/57633286 Acesso em: 15 maio 2020. 
[5] BRASIL. Informe no $\quad$ 07/2018 - $\quad$ COARE/FNDE. Disponível em: https://www.fnde.gov.br/index.php/programas/programas-do-livro/pnld/informe-pnld Acesso em: 15 maio 2020.

[6] BRASIL. Resolução CD/FNDE № 40, de 26 de julho de 2011. Dispõe sobre o Programa Nacional do Livro Didático do Campo (PNLD Campo) para as escolas do campo. 2011. Disponível em: http://portal.mec.gov.br/index.php?option=com_docman\&view=download\&alias=10044-resolucao-04026072011\&category_slug=fevereiro-2012-pdf\&Itemid=30192 Acesso em: 15 maio 2020.

[7] BRASIL. Lei no 9.394, de 20 de dezembro de 1996. Estabelece as diretrizes e bases da educação nacional. Brasília, 1996. Disponível em: http://www.planalto.gov.br/ccivil_03/Leis/19394.htm. Acesso em: 15 de maio de 2020.

[8] BRASIL. Constituição da República Federativa do Brasil. Brasília, DF: Senado Federal: Centro Gráfico, 1988.

[9] CARPANEDA, Isabella e BRAGANÇA, Angiolina. Coleção Girassol - Saberes e Fazeres do Campo. São Paulo: Editora FTD/S.A, 2013.

[10] COSTA, Ana Claudia de Andrade. Narrando o que ninguém viu, sobre aquilo que todo mundo vê: memórias e histórias das comunidades rurais do oeste potiguar. 2018. 55f. Monografia de conclusão de curso. Universidade Federal Rural do Semi-Árido. 2018.

[11] CUNHA, Maria Teresa. As escritas ordinárias na perspectiva da cultura escolar (segunda metade do século XX) In. Seminário sobre cultura escolar: perspectivas históricas, 2005. Curitiba: UFPR, 2005 a. 1 cd-rom.

[12] CALVÓ, Pedro Puig. Introdução. In: Pedagogia da Alternância - alternância e desenvolvimento. Primeiro Seminário Internacional. Salvador: Dupligráfica Editora, 1999.

[13] HAGE, Salomão e ANTUNES-ROCHA, Maria Isabel (Org's). Escola de Direito: Reinventando a Escola Multisseriada. Belo Horizonte, Autentica Editora, 2010.

[14] RODRIGUES, Hanslilian Correia Cruz. BONFIM, Hanslivian Correia Cruz. A educação do campo e seus aspectos legais. Curitiba, 2017. ISSN 2176-1396. Disponível em: https://educere.bruc.com.br/arquivo/pdf2017/25287_12546.pdf. Acesso em: 15 de maio de 2020.

[15] REIS, Pedro. Observação de aulas e avaliação de desempenho docente. Ed. Ministério da Educação, Lisboa Junior de 2011. Disponível em: http://www.ccap.min-edu.pt/docs/Caderno_CCAP_2-Observacao.pdf . Acesso 15 de maio de 2020 


\section{Capítulo 15}

Restinga de massambaba: Importância ecológica. Utilização da fotografia na construção do saber no Ensino Fundamental

\section{Lillian da Silva Oliveira \\ Lenilda Pereira dos Santos \\ Jaildo Assis da Silva}

Resumo: A pesquisa foi desenvolvida na escola Municipal Professora Tania Maria Gomes de Ávila no município de Cabo Frio- RJ, com alunos de 6o ao 9o ano, na disciplina de Geografia, abordando o uso da fotografia como instrumento de ensino aprendizagem. 0 desenvolvimento da proposta da prática pedagógica foi realizado com o uso do dispositivo móvel, o celular dos discentes e a prática de pesquisa deu-se através da aula de campo na Restinga de Massambaba com a professora regente da turma, os estudantes e um guia local. 0 conteúdo trabalhado foi a importância da preservação ambiental da restinga. Um bioma presente em toda a região dos Lagos no estado do Rio de Janeiro. A prática resultou em uma experiência satisfatória devido aos alunos terem compreendido, primeiramente, a importância da preservação ambiental e a descoberta da fauna e flora presentes neste bioma, os quais, eles reconheceram espécies nativas que encontravam no bairro em que habitavam, e algumas até em seus quintais e jardins.

Palavras- chave: Educação Ambiental, Restinga, Fotografia, Ensino Fundamental. 


\section{INTRODUÇÃO}

O Brasil, dentre poucos países, ainda possui grandes áreas ambientais com uma imensa variedade de espécies de vegetais e animais, sendo algumas dessas espécies ainda não estão catalogadas. Existem áreas ainda não pesquisadas por cientistas, tornando-as assim importantíssimas para a sociedade e pesquisas futuras.

Importante ressaltar que o aumento do crescimento populacional traz consequências bem como: o aumento da produção de bens de consumo e a demanda do aumento da produção de alimentos, necessitando sobretudo de novas áreas habitacionais, acarretando um possível desmatamento.

No ano de 1992, na cidade do Rio de Janeiro, ocorreu a Conferência das Nações Unidas sobre o Meio Ambiente e Desenvolvimento, com a participação de mais 156 Estados. Foi assinado nesse evento a Convenção da Biodiversidade, onde dentre seus artigos destacamos o artigo 6 que trata da necessidade de desenvolver estratégias, planos ou programas para conservação e a utilização sustentável da diversidade biológica.

Segunda as orientações da Convenção sobre diversidade biológica - CDB (1994), destacamos as observações o artigo 6:

\section{Artigo 6 - Medidas Gerais para a Conservação e a Utilização Sustentável}

Cada Parte Contratante deve, de acordo com suas próprias condições e capacidades:

a) Desenvolver estratégias, planos ou programas para a conservação e a utilização sustentável da diversidade biológica ou adaptar para esse fim estratégias, planos ou programas existentes que devem refletir, entre outros aspectos, as medidas estabelecidas nesta Convenção concernentes à Parte, interessada; e

b) integrar, na medida do possível e conforme o caso, a conservação e a utilização sustentável da diversidade biológica em planos, programas e políticas setoriais ou intersetoriais pertinentes.

Diante desse cenário, surge a proposta para a criação de Unidade de Conservação que se baseia na participação da sociedade e fundamentação em sólidas bases científicas. Foi criada a lei 9.985 de 18 de julho de 2000, que regulamentou o artigo 225 parágrafos $1^{\circ}$ incisos I, II, III e VII da Constituição Federal.

De acordo com o Ministério do Meio Ambiente:

“A criação de uma UC geralmente se dá quando há uma demanda da sociedade para proteção de áreas de importância biológica e cultural ou de beleza cênica, ou mesmo para assegurar o uso sustentável dos recursos naturais pelas populações tradicionais. É importante que a criação de uma UC leve em conta a realidade ambiental local, para que exerça influência direta no contexto econômico e socioambiental."

A criação da Área de Proteção Ambiental (APA) de Massambaba, criada em 1986 e administrada pela FEEMA, abrange $76,3 \mathrm{~km}^{2}$ de restingas, lagoas e morros baixos. Essa reserva ambiental será o objeto de visitação dos discentes da escola pública do município de Cabo Frio-RJ.

A pesquisa restringe sobre o conhecimento da restinga de Massambaba. Um bioma encontrado na parte litorânea, entre o município de Saquarema, Araruama e Arraial do Cabo, denominada Área de Proteção Ambiental (APA) de Massambaba.

O trabalho de Campo surgiu como proposta de trabalho em conduzir os alunos do Ensino Fundamental do segundo segmento, do $6^{\circ}$ ano ao $9^{\circ}$ ano, para uma aula de campo em uma restinga, propondo o conhecimento e a importância do bioma encontrado na Restinga de Massambaba, onde o uso da fotografia, através do celular seria o registro da reserva visitada.

Vale salientar que a atividade realizada buscará respostas investigativas relacionadas ao perfil dos discentes nos tempos em que o uso da fotografia, através das novas tecnologias, aqui representadas pelos aparelhos celulares em ambientes educacionais, como se tornaram necessárias. 
Temos que amadurecer que o uso do celular como ferramenta auxilia no processo de ensino e aprendizagem, assim como Lévy (1999), acreditamos que "O uso crescente de tecnologias digitais e redes de comunicação interativa acompanha e amplifica uma profunda mutação na relação com o saber" (p. 172).

Salienta Lévy que, “a aceleração da mudança, a virtualização, a universalização sem clausura são tendências de fundo, muito provavelmente irreversíveis, que devemos integrar em todos os nossos raciocínios e em todas as nossas decisões." (p. 219).

A educação contemporânea perpassa por modificações. O novo requer mudanças e essas transformações incide em uma nova dinâmica de ensinar, em que o docente é o mediador e o aluno deixa de ser passivo e a educação é uma criação coletiva.

Às vezes, mal se imagina o que pode passar a representar na vida de um aluno um simples gesto do professor. 0 que pode um gesto aparentemente insignificante valer como força formadora ou como contribuição à do educando por si mesmo. (FREIRE. 1996, p.47.)

Nesse mesmo patamar Libâneo adverte que a educação:

"corresponde, pois, a toda modalidade de influências e inter-relações que convergem para a formação de traços de personalidade social e do caráter, implicando uma concepção de mundo, ideais valores, modo de agir, que traduzem em convicções ideológicas, morais, políticas, princípios de ação frente a situações reais e desafios da vida prática." ( LIBÂNIO.1999, p.22-23)

Para Luckesi, a educação “...é um típico 'que fazer' humano, ou seja, um tipo de atividade que se caracteriza fundamentalmente por uma preocupação, por uma finalidade de a ser atingida. (LUCKESI. 1994,p.30)

\section{METODOLOGIA}

O estudo realizado na Restinga de Massambaba, situada nos municípios de Saquarema, Araruama e Arraial do Cabo no Estado do Rio de Janeiro, objetivou analisar como a fotografia instrumentaliza a educação ambiental e como pode contribuir para o aprendizado dos alunos de ensino fundamental do segundo segmento. E ainda verificar se a fotografia promove e incentiva a educação ambiental.

A metodologia utilizada baseou-se em um estudo experimental de abordagem qualitativa, com a aspiração de investigar os resultados e as relações de causa e efeito, testando a hipótese da utilização da fotografia através dos celulares como ferramenta de apoio no processo de ensino-aprendizagem e preservação ambiental.

Desse modo, sob a abordagem estética, o discurso visual utilizado na fotografia, visa à compreensão de uma temática ambiental, que é representada com diferentes enfoques, partindo do olhar do educando.

Para fins de sistematização esse estudo foi estruturado em tópicos. 0 primeiro passo foi trabalhar em grupo, em sala de aula, utilizando fichas dos seres vivos do Centro de Diversidade Vegetal da Restinga de Massambaba, onde foi apresentado a eles a importância ecológica dessa biodiversidade.

0 segundo momento ocorreu em uma aula de campo através de um percurso em uma trilha na restinga acompanhada por um guia local. No decorrer do percurso, os alunos registravam os aspectos da biodiversidade observada, utilizando como ferramenta de registro, o aparelho celular através da fotografia.

Por fim, o terceiro momento traz a leitura da paisagem através da fotografia. Essa dinâmica foi realizada em sala de aula. Cada turma fez uma leitura das fotografias apresentadas pelos colegas. Em uma outra etapa, os estudantes realizaram uma leitura da paisagem, utilizando os recursos oriundos das fotografias, onde em que cada uma das turmas fez uma leitura das fotografias, as quais foram apresentadas pelos colegas da turma. Na sequência, houve a realização de uma leitura reproduzindo os desenhos coletivos ou individuais, deixando aberta a forma de apresentação. Finalmente houve a oportunidade de cada turma apresentar o resultado de seus trabalhos através do mural da Escola, do facebook da Escola, onde aconteceu inclusive debates, rodas de conversas, contextualizando os diversos registros observados na execução do trabalho. 
Importante salientar que muitos desses alunos moram em área de invasão, predominadas por restinga. Daí a importância de fortalecer o compromisso de preservação e consciência ambiental.

É considerável ressaltar que a estratégia para leitura da imagem foi desenvolvida em três etapas: observação, análise e interpretação. Sendo assim, Flusser (1985, p.14) diz que "imagens são mediações entre o homem e mundo", ou seja, a análise da imagem é também uma tentativa de compreender especificidades da mediação e de como ela age na vida humana através de sua constituição ética e estética.

\title{
3. REFERENCIAL TEÓRICO
}

Na escola, a educação não pode estar alheia ao novo contexto sociotécnico. Na perspectiva da interatividade, o professor do presente deve deixar de ser um transmissor de saberes para converter-se em um provocador de interrogações, coordenador de equipes de trabalho, de uma educação que, em vez de prender-se à transmissão, valoriza e possibilita o diálogo e a colaboração.

A dinâmica da educação ambiental sofre com a falta de recursos (materiais, insumos etc.) para que esta se faça presente nas escolas. Portanto, a fotografia é uma opção, pois vem sensibilizar, através da figura, a beleza de seus componentes, e ensinar por meio das informações transmitidas e contidas nela, ou que podemos extrair do seu conteúdo.

Os sujeitos ativos dessa pesquisa são alunos que vivem em ambiente perturbador. Sob a influência do tráfico de drogas, invasão da polícia diariamente, impedindo que esses adolescentes não consigam ver o belo nas pequenas coisas, nem a ideia de preservação ambiental. Apesar de morarem próximo à restinga, não conseguem identificar nada além de lugar de invasão para construir um "canto", uma casa. Há Lixo por toda parte, retiradas de plantas ornamentais para gerar renda, enfim, tudo que contraria às leis de preservação.

Toda a proposta traz uma alternativa que foge ao ambiente familiar. A utilização de imagens através das fotografias, a aula de campo, a biodiversidade da restinga trazem um olhar diferenciado nas aulas de geografia, possibilitando a inserção de conceitos importantíssimos para a disciplina, além da paisagem, do lugar e do espaço geográfico e suas dinâmicas incorporam também o ecossistema, a preservação ambiental.

Nas palavras de Asari, Antoniello e Tsukamoto (2004, p. 183),

\begin{abstract}
“(...) a utilização da fotografia pode estimular a observação e descrição das paisagens pelos alunos, preparando-os para tirarem suas próprias conclusões e elaborarem soluções para problemas da sua realidade, e não apenas como uma ilustração do conteúdo geográfico ministrado" (ASARI; ANTONIELLO; TSUKAMOTO, 2004 apud; MUSSOI, 2008)
\end{abstract}

A área de Proteção Ambiental de Massambaba (Apa de Massambaba) é uma unidade de uso sustentável criada pelo decreto estadual № 9.529 - C, 15/12/1986.Abrange aproximadamente 7.630 hectares, situando-se entre os municípios de saquarema, Araruama e Arraial do Cabo. Portanto, uma área de preservação pela sua importância para o ciclo da vida, da fauna e da flora da região. É importante introduzir essa realidade para o meio escolar para que os discentes despertem a consciência de preservação e respeito ao meio ambiente.

Dessa forma, a restinga, objeto de estudo, é encontrada nessa área. Sendo definida como um terreno arenoso e salino, adjacente ao mar e coberto de plantas herbáceas características. As restingas são encontradas na costa, e por condições edáficas (solo arenoso) e pela influência marinha têm origem sedimentar recente.

Segundo a Resolução do CONAMA Nº 7 de 23 de julho 1996,

"entende-se por vegetação de restinga o conjunto das comunidades vegetais, fisionomicamente distintas, sob influência marinha e fluvio-marinha. Estas comunidades, distribuídas em mosaico, ocorrem em áreas de grande diversidade ecológica sendo consideradas comunidades edáficas por dependerem mais da natureza do solo que do clima". 
Vale ressaltar que foi utilizada como metodologia educacional a ferramenta da tecnologia digital através do celular para alcançar a captura ecológica e ambiental através da fotografia. A fotografia é uma forma objetiva de documentação. Ela captura aquilo que, a olho nu, passaria desapercebido.

\section{RESULTADO E DISCUSSÃO}

De acordo com a literatura, a Educação Ambiental é um canal incentivador para que a apreensão de conceitos importantes sobre preservação e conhecimentos ambientais sejam repassados aos educandos. Sendo assim, contribui para o indivíduo interagir com ambiente onde ele vive, criando um pensamento crítico, questionando a sociedade e transformando sua visão de mundo. A escola tem um papel fundamental nessa preparação do aluno.

Segundo Segura (2001):

A escola foi um dos primeiros espaços a absorver esse processo de "ambientalização" da sociedade, recebendo a sua cota de responsabilidade para melhorar a qualidade de vida da população, por meio de informação e conscientização.(SEGURA.2001, p.21)

E nesse mesmo diapasão Segura (2001) afirma:

Para a EA vista como aposta de vida, prática cidadã e construção cotidiana de uma nova sociedade, este conceito parece mais "iluminado" de sentido pois estabelece uma série de outras conexões importantes: a relação eu-nós pressupõe envolvimento solidariedade e a própria participação. Poderia ter escolhida "conscientização" ou "sensibilização", talvez as expressões mais citadas quando se fala em EA, mais foi buscada no conceito de pertencimento uma síntese dessas duas ideias. ( SEGURA ,2001, p. 48).

Apesar de estarmos inseridos num cotidiano escolar tumultuado com as práticas estabelecidas pela rotina escolar, vale a pena os alunos vivenciarem essa experiência ambiental, ecológica, enfim, descobrir que há muitas coisas a serem realizadas ao seu redor.

Vale lembrar que o uso da fotografia na educação ambiental ainda é um aspecto pouco discutido em relação à prática nas escolas e, consequentemente, à interpretação das imagens.

Carvalho e Grun (2005):

É dentro deste repertório de sentidos sociais que a educação, enquanto prática interpretativa aciona ênfases e constrói, dentro de sua autonomia relativa, uma via compreensiva do meio ambiente enquanto campo complexo das relações entre natureza e sociedade. 0 educador ambiental, neste sentido, seria um intérprete dos nexos que produzem os diferentes sentidos do ambiental em nossa sociedade. Ou ainda em outras palavras, um intérprete das interpretações socialmente construídas (CARVALHO E GRUN, p.180-181).

A pesquisa nos leva argumentar a aplicação da fotografia na educação ambiental, com um olhar desafiador, crítico, procurando, através do processo educativo, o desenvolvimento do que denominamos de olhares perceptivos, isto é, olhares capazes de incorporar as fotografias de uma forma crítica, em que nascerá uma geração com atitudes e opiniões diferentes, preparando um caminho sempre novo para aqueles que ainda hão de vir.

\section{CONSIDERAÇÕES FINAIS}

A transdisciplinaridade é uma exigência da educação atual para que diminuam as fronteiras disciplinares e que a escola, os alunos e a própria educação ganhem novas formas. É necessária diminuir essa forma cartesiana de ensino. Devemos ensinar além muros, para a vida, para o cotidiano. 
Agregar valores, desmontar conceitos antigos, enfim, levar os alunos a pensar, raciocinar e se tornarem protagonistas em seu tempo. Aproximar as disciplinas, as ciências, à estética, às artes, enfim, gerar novos conceitos e informações de qualidade.

Vale salientar que o resultado dessa pesquisa, a fotografia, compõe um elo entre a realidade concreta e o artístico, entre um recorte espacial com o todo que se relaciona, entre o encontro do olhar externo com o interno.

Podemos apresentar que há diferentes formas de uso, tanto na pesquisa, como no ensino em educação ambiental. Como ponto de atenção, devemos ressaltar ao modelo de vida que se está experimentando socialmente que deve servir de força motriz para a reflexão sobre o que se quer construir e, percebendo, qual é a imagem que se pretende deixar para os novos tempos e futuras gerações.

Essa investigação está longe de esgotar todas as possibilidades de uso da fotografia no campo da educação ambiental. Torna-se, assim, um convite para que se aprofunde o diálogo, explorando cada vez mais a fotografia como linguagem e expressão, considerando sua potência para o ensino, pesquisa e vivência para a transformação socioambiental.

Assim sendo, a Interpretação Ambiental deve extrapolar a visão reducionista e ser abordada de forma ampla, trabalhando todos os aspectos em sua totalidade, sobretudo as questões que extrapolam os temas ambientais.

O aluno deve ter a capacidade de concretizar o que está relacionado aos ecossistemas da região, como costões rochosos, manguezais, dunas e associá-las às questões socioambientais. Portanto, a Interpretação Ambiental aliada a uma Educação Ambiental transformadora pode representar uma importante contribuição na conservação e manutenção do meio ambiente.

\section{REFERÊNCIAS}

[1] ALMEIDA. Rosângela Doim de. A propósito da questão teóricometodológica sobre o ensino de Geografia. Terra livre no 08. São Paulo: Ed. Marco Zero, 1991.

[2] FLUSSER, Vilém. Filosofia da caixa preta: ensaios para uma futura filosofia da fotografia. São Paulo: Hucitec, 1985.

[3] LIBÂNEO, José Carlos. Adeus professor, adeus professora ? novas exigências educativas e profissão docente / José Carlos Libâneo. 6. ed.- São Paulo: Cortez, 2002.

[4] DIDATICA. 2º ed. São Paulo: Editora Cortez, 1999.

[5] BRASIL.Ministério do Meio Ambiente. 2005. Consumo Sustentável: Manual de educação. 1ed. Ministério do Meio Ambiente, Brasília. 160 p.

[6] BRASIL. Ministério do Meio Ambiente. Sistema Nacional de Unidades Conservação - SNUC. 2013. Disponível em.< https://www.mma.gov.br/areas-protegidas/unidades-de-conservacao/sistema-nacional-de-ucssnuc.html>Acesso em 20 outubro 2018.

[7] Freire, Paulo."Pedagogia do Oprimido”, Rio de Janeiro, Paz e Terra, 218p. 1970

[8] _ _ PEDAGOGIA DA AUTONOMIA, Rio de Janeiro, Paz e Terra, Coleção Leitura, 17a Ed.1996

[9] FREIRE, Paulo. Pedagogia da autonomia: saberes necessários à prática docente. 33a ed. São Paulo: Paz e Terra, 1996

[10] Zanin, E. M. 2006. Projeto trilhas interpretativas - a extensão, o ensino e a pesquisa integrados à conservação ambiental e à educação. Vivências. 1: 26-35.

[11] BRASIL, Ministério do Meio Ambiente. Convenção sobre biodiversidade biológica.Brasília, DF.1994. Disponível em<https://www.mma.gov.br/informma/item/7513-convencao-sobre-diversidade-biologica-cdb. > Acessado em 20/05/20202

[12] BRASI. Constituição(1988).CONSTITUIÇÃO DA REPÚBLICA FEDERATIVA DO BRASIL:promulgada em 5 de outubro de 1988. 4. Ed. SÃO PAULO. SARAIVA, 1990

[13] ARAUJO, Dorothy Sue Dunn de et al. Área de Proteção Ambiental de Massambaba, Rio de Janeiro: caracterização fitofisionômica e florística. Rodriguésia [online]. 2009, vol.60, n.1, pp.67-96. ISSN 2175-7860. Disponível em https://doi.org/10.1590/2175-7860200960104. Acessado em 10 maio 2020 
[14] LÉVY, Pierre. Cibercultura. São Paulo: Editora 34, 1999.

[15] LUCKESI, Cipriano C. Filosofia da Educação. São Paulo: Cortez, 2001citado por NERI DE PAULA CARNEIRO . Disponível em< https://meuartigo.brasilescola.uol.com.br/filosofia/educacao-educacao-escolar.htm. Acessado em 20 de maio 2020

[16] PICOLI,Daniele Saifert . BONI, Paulo César. A estética da imagem e o discurso de proteção ambiental: a produção de sentido na fotografia e no cinema. Disponível em< http://www.uel.br/revistas/uel/index.php/discursosfotograficos/article/view/1508/1254. Acessado em 19 de maio de 2020

[17] SALEME, FERNANDA. Interpretação ambiental, aspectos biológicos e educacionais do Parque Estadual da Costa do Sol e da Área de Proteção Ambiental do Pau-Brasil nos limites do município de Cabo Frio - RJ.2016. $72 f$. DISSERTAÇÃO ( Mestrado Profissional em Biodiversidade em Unidades de Conservação, Rio de Janeiro,RJ, 2016.

[18] ASARI; ANTONIELLO; TSUKAMOTO, 2004 apud; MUSSOI, 2008.Citado em O direito à cidade: a partir das vivências dos alunos da educação de jovens e adultos no grupo escolar Senador Ovídio Teixeira.Silva, Edineuza,Et al Ensino e práticas do ensino da geografia .Editora ApprisLtda 2016 - 1o edição.

[19] BRASIL, Resolução CONAMA nº7, de 23 de junho de 1996. Publicada no DOU no 165, de 26 de agosto de 1996, Seção 1, páginas 16386-16390

[20] SEGURA, Denise de S. Baena. Educação Ambiental na escola pública: da curiosidade ingênua à consciência crítica. São Paulo: Annablume: Fapesp, 2001. 214p. citado em A Importância da educação ambiental na escola nas séries iniciais. GL de Sousa, AB de Medeiros e outros- Revista Eletrônica Faculdade Montes Belos, 2011 revista.fmb.edu.br

[21] CARVALHO, I.C.M. e GRUM, M. Hermenêutica e educação. In: FERRARO JUNIOR, L.A. Encontros e Caminhos : Formação de educadoras(es) ambientais e coletivos educadores. Brasília: MMA, Diretoria de Educação Ambiental, 2005. 
ANEXOS

Foto 01: Foto do Autor - Restinga - 2018

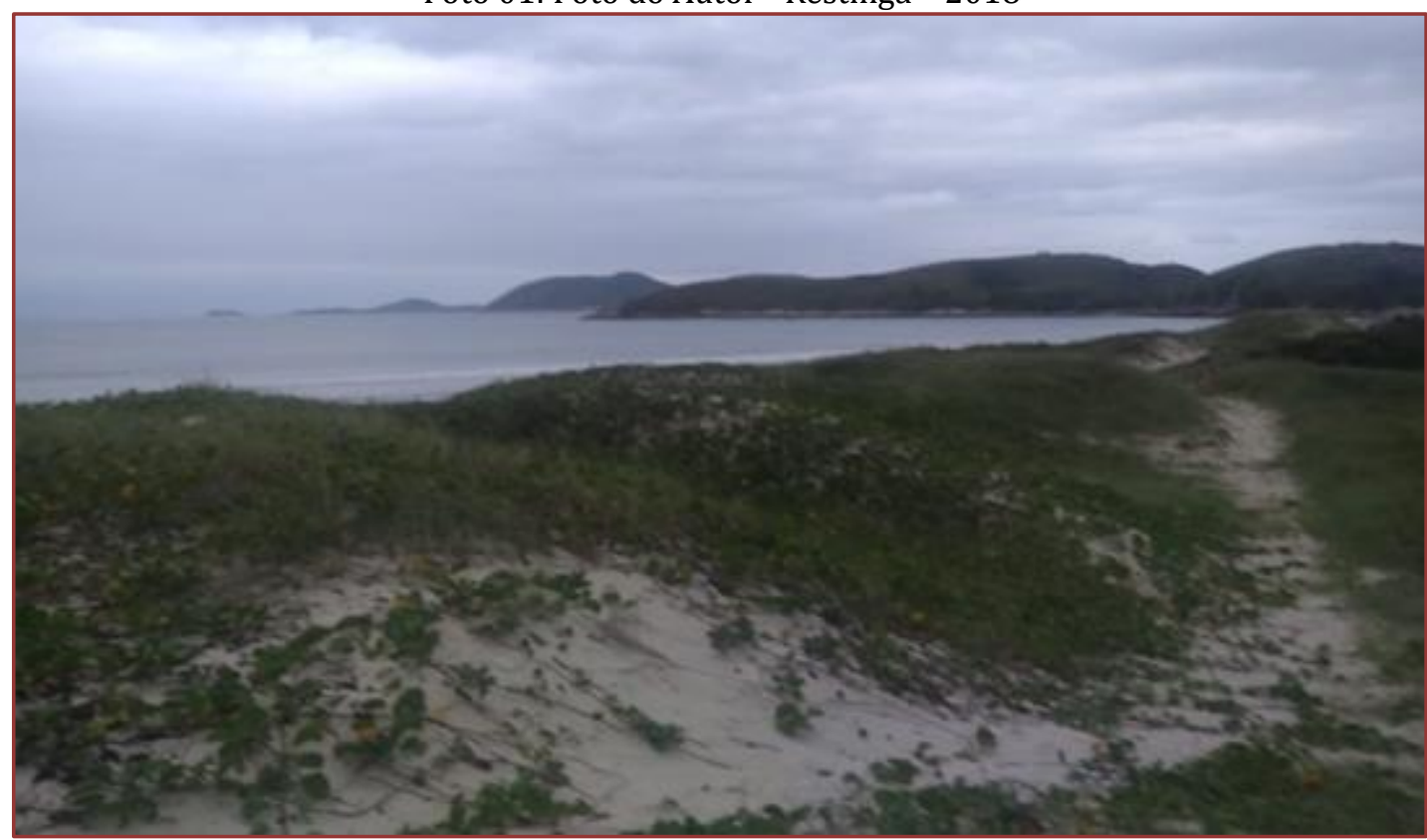

FONTE: AUTOR. ANO 2018 Espécie: Ipomoea pes-carprae (L)R.Br.

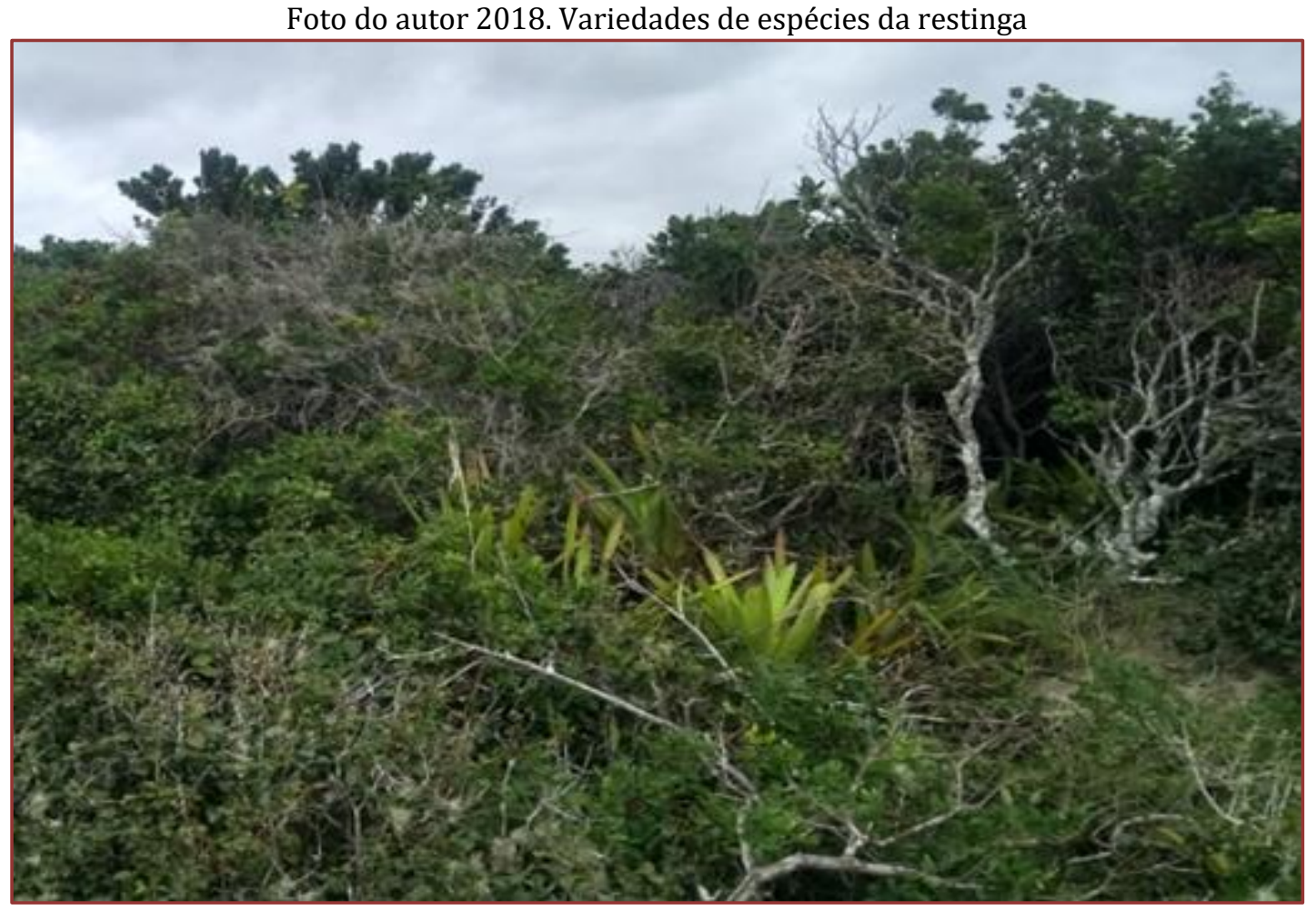

Foto do autor 2018 - Coquinho Guriri - Allagoptera arenaria 


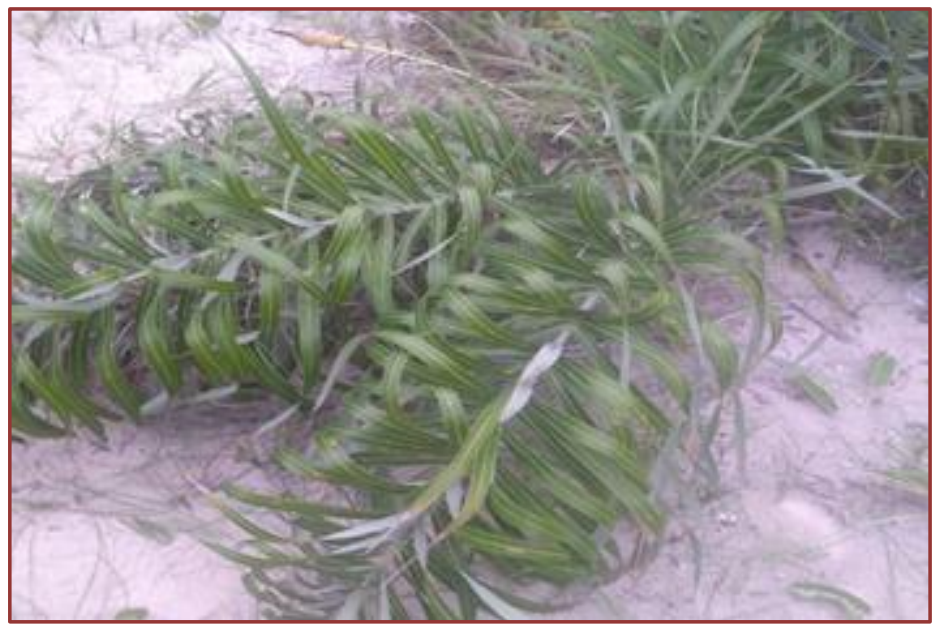

Foto do Autor - 2018 - Bromélia - Neoregelia crurenta ( família bromeliaceae)

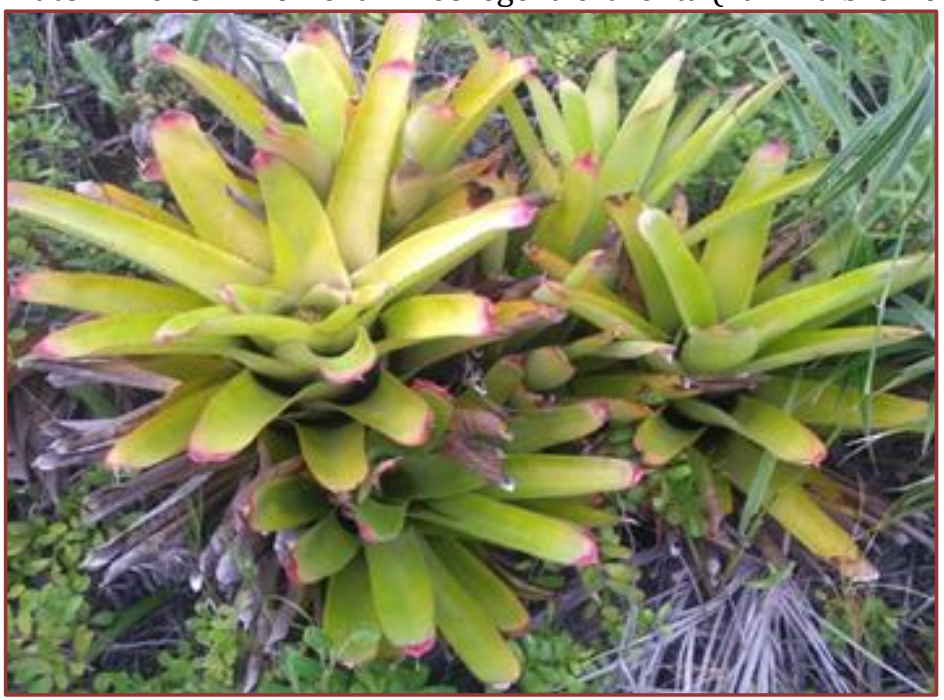

Foto do autor - 2018 - Família: Cactaceae Espécie: Pilosocereus ulei.

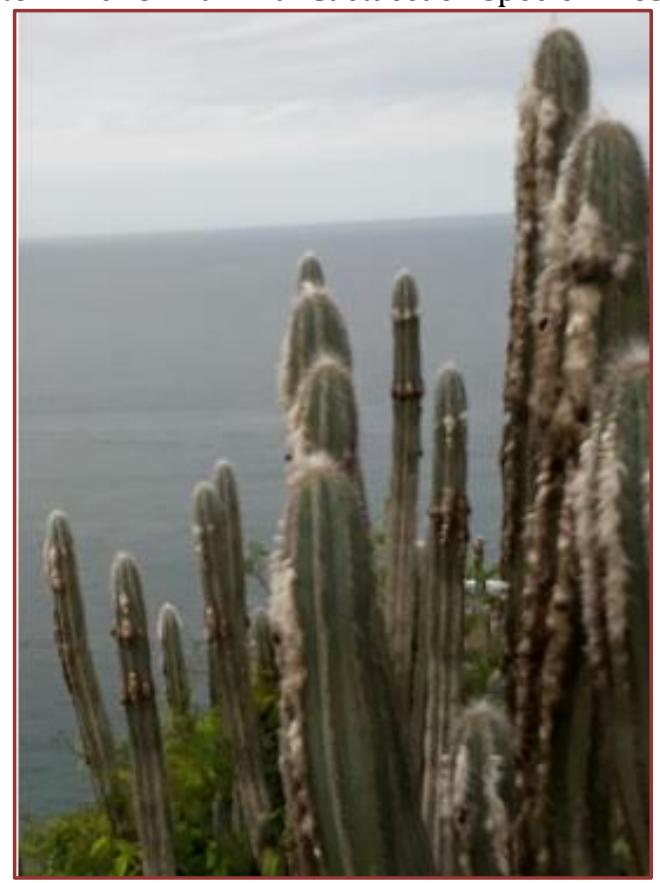




\section{Capítulo 16}

Aprendizagem baseada em jogos: Experiência no ensino de física

Messias Vilbert de Souza Santos

Francisco Genivan Silva

Isadora Azevedo Medeiros do Nascimento

Quezia Assis de Sousa

Edicarlos Medeiros Batista

Resumo. A aprendizagem baseada em jogos desenvolveu uma reputação entre os educadores, sendo percebida como uma forma atrativa de aprendizagem suplementar, com potencial de proporcionar melhorias no processo educacional, abrangendo os diferentes níveis de ensino. Este artigo apresenta um relato de experiência quanto ao uso de jogos para o ensino da física. 0 estudo foi realizado entre estudantes do ensino médio para verificar o potencial deste recurso para implementar melhorias no ensino e aprendizagem. Ao fim do estudo, verificou-se boa aceitação das atividades pelo corpo discente, aumento de rendimento, bem como resultados positivos no que diz respeito a assimilação dos conteúdos e participação dos alunos. 


\section{INTRODUÇÃO}

Com o desenvolvimento acelerado de tecnologias, percebe-se, naturalmente, uma crescente ascensão de aspectos relativos à ciência da computação no convívio social. No que concerne ao âmbito educacional, essa realidade não é diferente, sendo possível verificar a potencialidade de vários conhecimentos relacionados a área tecnológica para o melhoramento do processo de ensino, como por exemplo o uso de jogos eletrônicos e da gamificação [Medeiros et al. 2018].

Muitas são as estratégias e ações desenvolvidas ao longo dos últimos anos na educação com a perspectiva de suprir carências e aprimorar o processo de ensino através ou com ajuda da computação. 0 uso de jogos educacionais tem se tornado mais comum, principalmente, para o ensino de matemática e ciências [Hainey et al. 2016]. Para Pietruchinski et al. (2011), os jogos são ferramentas capazes de auxiliar no processo educativo, desde que sejam planejados e trabalhados de uma forma crítica, que possibilite a aprendizagem de uma maneira significativa ao aprendiz.

Nesta perspectiva, conforme Prensky (2012), a aprendizagem baseada em jogos está de acordo com as necessidades e os estilos de aprendizagem da geração atual e das futuras gerações. É motivadora, divertida e versátil, capaz de ser adaptada a quase todas as disciplinas, informações ou habilidades, mas só acontece quando tanto o envolvimento quanto a aprendizagem são altos. Isso é corroborado por suas características inerentes, tais como competição, desafio, interação, feedback.

Conforme demonstrado por Medeiros e Medeiros (2002), a física qualifica-se como uma disciplina que, ao englobar diferentes conceitos, denota alta complexidade e abstração. Comumente, são encontradas barreiras para o desenvolvimento pleno da área, dado que, boa parte dos discentes, apresentam desinteresse e desmotivação quanto às metodologias habituais empregadas para o ensino.

Por conseguinte, compreendendo a necessidade de avaliação de novas metodologias para o ensino de matérias regulares, este artigo refere-se à um relato de experiência do uso de jogos eletrônicos para complementar o ensino de física. 0 estudo foi efetivado com alunos dos cursos técnicos de nível médio em informática e mineração do campus avançado Parelhas/IFRN. Em uma perspectiva geral, a experiência fundamentou-se na realização de oficinas em três turmas da instituição, nas quais foram empregados jogos e simulações para explanação de conceitos físicos.

Por meio das atividades, que apresentavam como objetivo principal investigar e analisar as potencialidades e efeitos de uma metodologia baseada no uso de jogos para a disciplina física, encontraram-se resultados positivos quanto à aceitação da abordagem e absorção de conteúdos propostos pelo público observado.

\section{USO DE JOGOS NA EDUCAÇÃO}

Como demonstrado por Ramos (2014), as diretrizes dos Parâmetros Curriculares Nacionais (1977) admitem como um dos objetivos do ensino básico "o aluno ser capaz de resolver problemas, utilizando o pensamento lógico, [...], selecionando a sequência de ações para resolver o problema [...]". Portanto, consegue-se compreender que aprimorar os processos de ensino, adequando-os às perspectivas sociais atuais, configura-se como um pilar para o desenvolvimento pleno do que se entende por ensino essencial.

Nesse sentido, Kapp (2012, p.7) define jogo como "um sistema em que os jogadores se envolvem em um desafio abstrato, definido por regras, interatividade e feedback, que resulta em um resultado quantificável, muitas vezes provocando uma reação emocional". Na definição de Kapp, o jogo não está completamente separado das regras da realidade, pois imita situações e procedimentos da vida real. Não apenas os jogadores, no conceito de Kapp, interagem com o sistema, mas também entre si e com o conteúdo do jogo. Sendo assim, é possível antecipar as contribuições que as diversas ramificações dessa área podem proporcionar para o processo de ensino/aprendizagem de disciplinas como a física.

Especificamente, no que diz respeito à física, de acordo com Viana et al. $(2015, \mathrm{p} .2)$ é por meio desta que os alunos devem ser "capazes de interpretar fenômenos e processos naturais, situando e dimensionando a interação do ser humano com a natureza como parte da própria natureza em transformação". 
Nessa perspectiva, verifica-se a exigência de certa autonomia, capacidade de visualização e ação dos discentes sobre a compreensão dos fenômenos abordados pela disciplina, o que pode ser relacionado as características da aprendizagem mediada por jogos. Como demonstrado por Costa e Verdeaux (2016), a dinâmica apresentada por um jogo consegue moldar os desafios às habilidades do jogador, incentivando a realização de uma determinada tarefa com eficiência.

Logo, ponderando sobre os fatos citados anteriormente, é possível considerar uma convergência entre o ensino/aprendizagem da física auxiliado por meio de aspectos da ciência da computação, uma vez que, retomando ideias de Bordini et al. (2017) e Blikstein (2008) apud Santana (2017), estes favorecem a motivação, a criatividade e a produtividade.

\section{METODOLOGIA}

O presente estudo utilizou como método de pesquisa o relato de experiência de caráter qualitativo. A experiência descrita realizou-se nas dependências do campus avançado Parelhas/IFRN e teve como população de estudo uma amostra dos discentes da referida instituição, participantes dos cursos técnicos integrados em informática e mineração.

Essencialmente, as atividades realizadas relacionaram-se a promoção de oficinas, nas quais foram empregados diferentes jogos para desenvolvimento de uma aula de física. A pesquisa como um todo organizou-se em 5 fases distintas com diferentes propósitos, as quais estão identificadas e especificadas abaixo.

- $\quad$ Fase I - Aplicação de formulário diagnóstico que levantou dentre o corpo discente as principais dificuldades e predileções com relação à aprendizagem de física.

- $\quad$ Fase II - Elaboração de planos de ensino e dos testes que constituíram as oficinas. Basicamente, os assuntos tratados foram: cinemática e leis de Newton; eletrostática e constituintes da matéria.

- $\quad$ Fase III - Aplicação de pré-teste para verificação do conhecimento prévio dos estudantes com relação aos assuntos que seriam abordados durante as oficinas.

- $\quad$ Fase IV - Separação dos grupos por turma para aplicação dos tratamentos (metodologias de ensino) e execução das oficinas.

- $\quad$ Fase V - Aplicação de pós-teste e análise da situação de ensino-aprendizagem entre os estudantes e entre os grupos; análise da aceitação dos jogos e das metodologias propostas.

As atividades foram empreendidas com as turmas de informática $2^{\circ}$ ano (Vespertino), mineração $3^{\circ}$ ano (Vespertino) e informática 3ํano (Matutino) que, no presente artigo, são nomeadas como turmas 1, 2 e 3, respectivamente. As oficinas, que apresentaram uma duração de, aproximadamente, 2 horas cada, compreendiam a mesma dinâmica, havendo utilização de jogos e explanação complementar dos conceitos físicos pelo professor responsável.

Durante as oficinas, foram empregadas três ferramentas distintas para trabalhar aspectos da disciplina de física, dentre as quais duas eram jogos e uma configurou-se como material complementar, uma vez que se tratava de um quiz (entenda-se quiz como jogo de perguntas e respostas). Estes materiais integram o projeto PhET Simulações Interativas da Universidade de Colorado Boulder.

Inicialmente, pretendia-se selecionar diversos jogos relacionados a física e, em seguida, com auxílio do professor da disciplina, definir quais assuntos poderiam ser trabalhados. Entretanto, após pesquisa realizada nas principais plataformas digitais, como Play Store, Apple Store e Google, por meio de palavras chaves relacionadas a temáticas da física, foram encontrados poucos aplicativos que realmente se enquadrassem como jogos, constatando-se que, entre os avaliados, a grande maioria qualificava-se como quiz ou apenas tangenciavam conceitos da disciplina. Por isso, a escolha das ferramentas ficou a cargo do docente em física participante do projeto, o qual indicou a plataforma PhET por ser a que mais se alinhava com os objetivos estipulados para o trabalho. 
A partir do primeiro jogo, denominado "Módulo de pouso lunar", conseguiu-se trabalhar conceitos relacionados a cinemática e leis de Newton, mais especificamente, velocidade, aceleração, vetores, lei da inércia e ação e reação. De modo análogo, por meio do segundo jogo, "Hóquei no campo elétrico", e do quiz "Monte um átomo", foram explanados aspectos referentes ao conteúdo de eletrostática, detalhando tópicos como a constituição do átomo e sua estabilidade e a interação entre cargas.

Basicamente, as atividades realizadas apresentaram o mesmo progresso, incluindo a utilização de diferentes recursos. Inicialmente, foram aplicados os pré-testes (anexos A e B) relativos ao conteúdo da aula e logo em seguida houve a explicação do conteúdo e utilização dos jogos. Durante o processo, foram fornecidos 20 minutos para familiarização dos alunos com o jogo e em seguida mais 15 minutos para que estes o utilizassem efetivamente. Por fim, os discentes foram convidados a refazer os testes iniciais e a avaliar a experiência como um todo.

Contudo, é importante ressaltar que existiram diferenças quanto a ordem das atividades realizadas no decorrer da oficina, de modo a possibilitar diferentes análises. Estas variações ocorreram de acordo com as turmas e estão detalhadas abaixo.

- Turma 1: Utilização a priori do jogo “Módulo de pouso lunar” e explanação do conteúdo.

- Turma 2: Explicação do conteúdo, com a utilização de ferramentas auxiliares (quiz), e aplicação do jogo "Hóquei no campo elétrico".

- Turma 3: Utilização a priori de um jogo, explanação do conteúdo, aplicação do segundo jogo e desenvolvimento do conteúdo referente a este.

Como citado anteriormente, ao final de cada oficina foi fornecido aos alunos um questionário para avaliação dos jogos (anexo C), para isso foram utilizados os modelos desenvolvidos e apresentados por Savi et al. (2011) e por Martins et al. (2016). O formulário era composto por 26 afirmativas sobre três subescalas (motivação, experiência do usuário e aprendizagem) subdivididas em dez dimensões (atenção, relevância, confiança e satisfação, imersão, desafio, competência, divertimento, interação social e aprendizagem), as quais poderiam ser avaliadas por meio de 5 valores, $-2,-1,0,1,2$, que representavam, respectivamente, discordância total, discordância, indiferença, concordância e concordância total.

\section{RESULTADOS E DISCUSSÕES}

Por meio da experiência descrita neste artigo, foi possível a obtenção de dados quanto as perspectivas relacionadas ao ensino da física e o uso de jogos, os quais podem ser subdivididos em três dimensões principais, que se referem à disciplina abordada pelo projeto em específico, a aprendizagem e a aplicação da metodologia.

Previamente, por meio de formulário eletrônico, realizou-se entre os alunos da escola uma pequena pesquisa sobre ensino da física, de modo a identificar as percepções dos estudantes quanto a essa ciência. No total, foram obtidas 77 respostas, as quais representavam, majoritariamente, discentes com idades entre 15 e 18 anos que já haviam cursado a disciplina.

Quanto à experiência com a física, 76,6\% dos alunos consultados afirmaram possuir alguma dificuldade na disciplina e 70,1\% consideraram que a principal complexidade da matéria estava relacionada à aspectos matemáticos. Esses indicadores demonstram que, dentro da visão do corpo discente, existem certos empecilhos para o desenvolvimento completo do processo de ensino/aprendizagem não só no que diz respeito a ciência da natureza em questão, como também da própria matemática.

Além disso, ao serem questionados sobre as diferentes formas de abordagem utilizadas no âmbito da disciplina e a aprendizagem individual, apenas 18,2 \% dos estudantes indicaram preferência por uma metodologia mais habitual, voltada para questões conceituais e fundamentadas no uso de quadro, livro e projetor. Por conseguinte, com base nos dados encontrados, reforça-se a ideia da necessidade de métodos e materiais suplementares mais atrativos, visto que processos mais dinâmicos e inovadores poderiam, provavelmente, amenizar a resistência verificada entre a maioria dos discentes e incentivar a participação destes nas atividades, melhorando o entendimento geral da disciplina.

No que diz respeito as oficinas, estas foram realizadas em três turmas com, respectivamente, 19, 18 e 20 alunos, totalizando 57 discentes. Inicialmente, foram aplicados pré-testes, que poderiam ser pontuados entre 0 e 100 pontos, de modo a verificar o conhecimento prévio dos participantes para nível de comparação. Do total de testes recolhidos, considerou-se apenas 56, uma vez que, na turma 1, um não apresentava respostas. 
Como demonstrado pela tabela 1 abaixo, averiguou-se certa discrepância entre as turmas, dado que os desempenhos dos participantes foram bastante diferentes, mesmo existindo conhecimento anterior dos conceitos tratados.

Tabela 1. Porcentagem equivalente a pontuação atingida no pré-teste

\begin{tabular}{|l|c|c|c|}
\multicolumn{1}{c}{ Pontuação atingida } & \multicolumn{3}{c|}{ Porcentagem de alunos } \\
\hline Entre 0 e 25 pontos & Turma 1 & Turma 2 & Turma 3 \\
\hline Entre 26 e 50 pontos & $44,4 \%$ & $11,1 \%$ & $35,0 \%$ \\
\hline Entre 51 e 75 pontos & $55,6 \%$ & $50,0 \%$ & $30,0 \%$ \\
\hline Entre 76 e 100 pontos & $0,0 \%$ & $38,9 \%$ & $25,0 \%$ \\
\hline
\end{tabular}

Na turma 1, por exemplo, conforme a tabela 1, todos os estudantes obtiveram notas menores ou iguais a metade do valor atribuído a avaliação. Semelhantemente, na turma 2, apenas 38,9\% atingiram uma pontuação superior a 50 pontos. Em contrapartida, na turma 3, consoante aos percentuais exibidos, observa-se claramente uma distribuição muito mais homogênea entre os componentes do grupo, encontrando-se inclusive notas acima dos 75 pontos.

Ao analisar-se os três resultados em conjunto, constata-se que a média geral entre os participantes foi de, aproximadamente, 40,8 pontos, e que 29 participantes obtiveram nota abaixo desse valor. Desse modo, assim como nos dados analisados na fase I da pesquisa, pode-se indicar a presença de déficits no processo de aprendizagem da física, sendo possível presumir a existência de problemas quanto à comunicação entre a disciplina e os alunos, os quais podem estar relacionados a questões como motivação.

Em momento posterior a realização das oficinas, os participantes do estudo foram convidados a responder novamente, se desejassem, os testes. Do total de alunos considerados (56), apenas 24, 8 em cada grupo, modificaram alguma das respostas. Contudo, apesar da pequena participação, pôde-se perceber resultados consideráveis, existindo aumento das notas iniciais em até 75 pontos. A comparação entre a notas obtidas pelos alunos que realizaram o pós-testes, 24 ao total, estão apresentadas abaixo. Vale destacar que para essa interpretação só foram consideradas as notas absolutas no teste final e não a diferença entre as pontuações das duas avaliações.

Tabela 2. Porcentagem equivalente a pontuação atingida no pós-teste

\begin{tabular}{|l|c|c|c|}
\multicolumn{1}{c}{ Pontuação atingida } & \multicolumn{3}{c|}{ Porcentagem de alunos } \\
\hline Entre 0 e 25 pontos & Turma 1 & Turma 2 & Turma 3 \\
\hline Entre 26 e 50 pontos & $25,0 \%$ & $0,0 \%$ & $0,0 \%$ \\
\hline Entre 51 e 75 pontos & $75,0 \%$ & $0,0 \%$ & $25,0 \%$ \\
\hline Entre 76 e 100 pontos & $0,0 \%$ & $50,0 \%$ & $12,50 \%$ \\
\hline
\end{tabular}

Apesar de ser necessário considerar que há uma maior retenção de conhecimentos quando estes são recém-apresentados, a partir desses dados, consegue-se reconhecer que há um grande potencial na utilização dos jogos, uma vez que por meio desta tornou-se possível explanar aspectos importantes da disciplina, de modo que os alunos conseguiram compreender os fenômenos e os conceitos. Ademais, podese ainda salientar que, esse resultado, reforça a ideia de que a abordagem utilizada contribuiu para um ganho dos conhecimentos fundamentais dentro dos conteúdos explanados. 
Para avaliação dos jogos, como citado anteriormente, foram utilizados questionários que compreendiam 26 afirmações relacionadas a 10 aspectos. Desse modo, após as oficinas foram recolhidos um total de 57 formulários avaliativos, dos quais apenas 49 foram considerados válidos. Dentre as turmas 1, 2 e 3, respectivamente, foram obtidas, 17,15 e 17 avaliações completas. Os gráficos abaixo apresentam os resultados alcançados em cada turma de acordo com os critérios disponibilizados.

Gráfico 1. Avaliação da turma 1 quanto ao jogo utilizado durante a oficina.

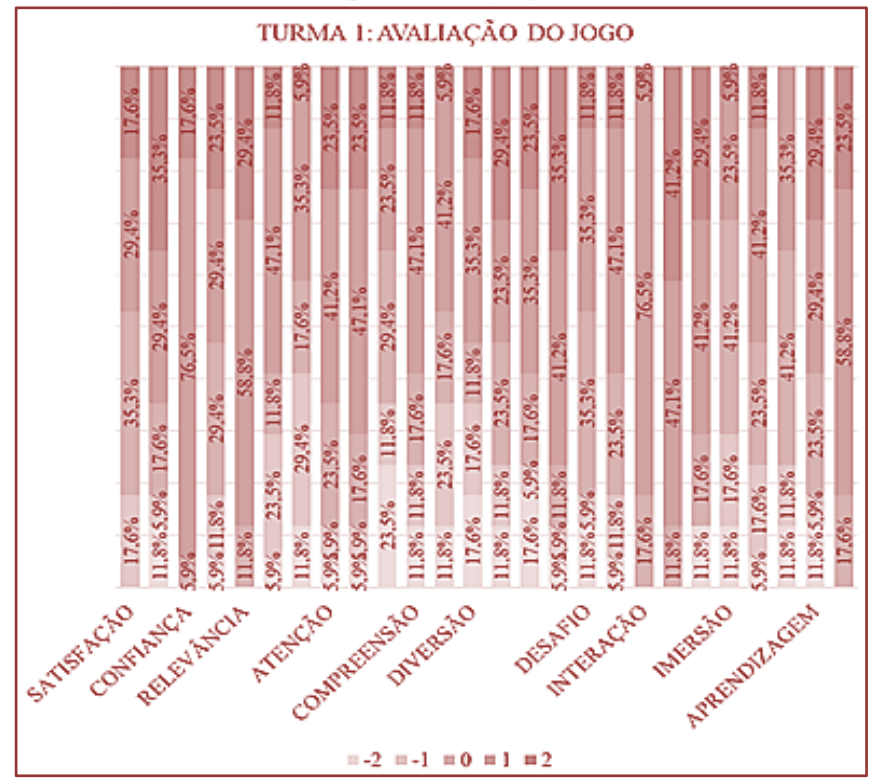

Gráfico 2. Avaliação da turma 2 quanto ao jogo aplicado durante a oficina.

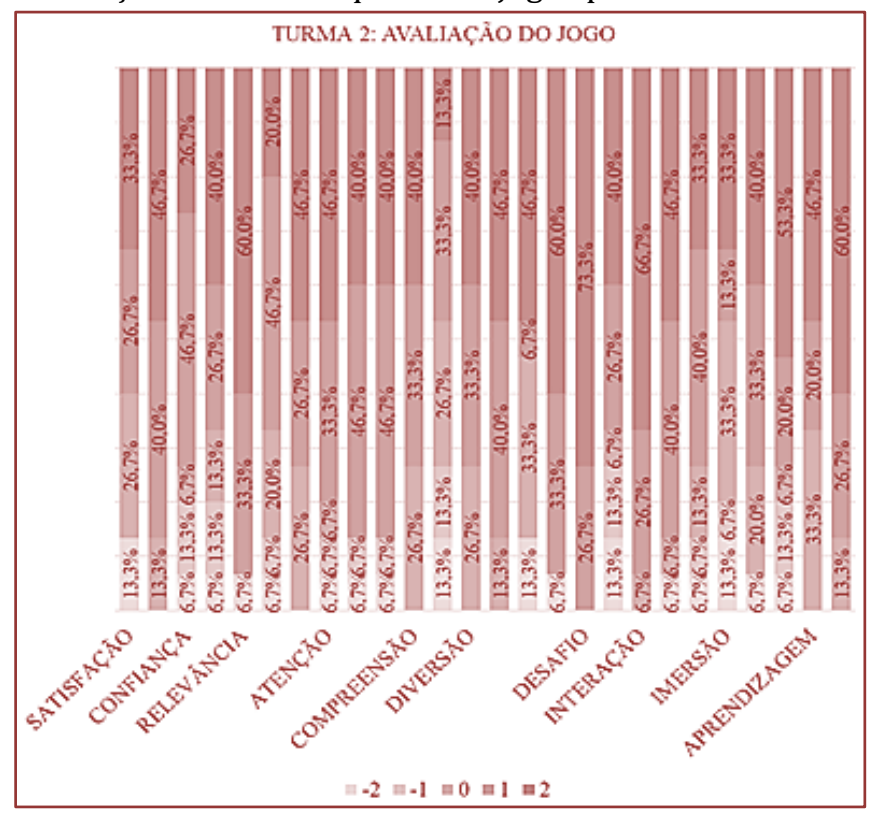


Gráfico 3. Avaliação da turma 3 quanto aos dois jogos utilizados durante a oficina

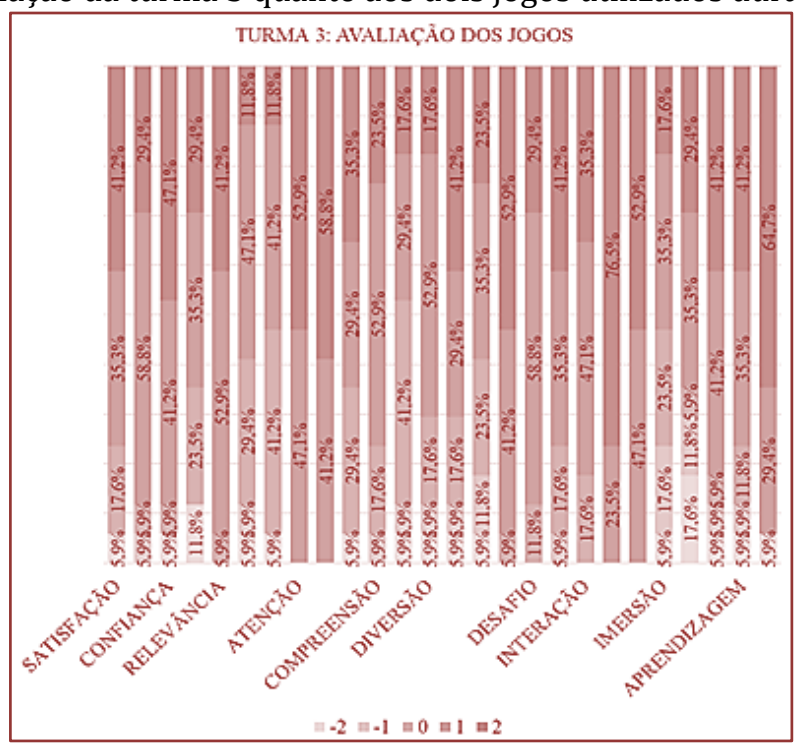

Em uma comparação geral dos dados apresentados nos gráficos acima, na categoria motivação, que engloba as dimensões atenção, relevância, confiança e satisfação, obteve-se uma aprovação expressiva dentre as respostas dos participantes, demonstrando um bom alcance dos jogos quanto à aspectos como desempenho pessoal e evolução.

Mais especificamente, no tópico satisfação, observa-se que as turmas 2 e 3 demonstraram melhores avaliações, o que pode indicar uma maior conexão entre as perspectivas dos alunos e o jogo "Hóquei no campo elétrico". Diferentemente, o grupo 1 demonstrou um posicionamento menos favorável, indicando menor engajamento por parte destes com relação ao jogo "Módulo de pouso lunar".

No que diz respeito a seção relacionada a experiência do usuário (imersão, desafio, competência, divertimento e interação social), a avaliação das turmas, novamente, manteve-se favorável, o que indica um desempenho significativo dos jogos em aspectos como desafio e diversão. Entretanto, assim como na categoria motivação, percebe-se uma melhor aceitação do jogo "Hóquei no campo elétrico". No caso da turma 3, que foi exposta aos dois jogos, percebe-se uma aproximação muito maior da avaliação correspondente a turma 2, sendo possível supor que a experiência com o jogo relacionado ao hóquei influenciou a avaliação do último grupo.

Além disso, averiguou-se que vários alunos demonstraram interesse nos jogos. Entre o total de participantes da oficina, aproximadamente $69 \%$ concordaram que recomendariam o jogo a outros colegas e, por volta de $65 \%$, consentiram que gostariam de utilizar as ferramentas apresentadas em outro momento.

Com relação a última categoria de avaliação, a qual referia-se à percepção de aprendizagem por meio dos jogos, as três turmas expressaram, majoritariamente, concordância total (valor 2 na avaliação) quanto a contribuição destes para o aprendizado dentro da disciplina, sendo importante destacar que, como nas outras seções, a turma 1 manifestou menor nível de aprovação. Entretanto, constatou-se que, apesar de concordarem com a contribuição dos jogos, os alunos demonstraram um posicionamento neutro expressivo quanto à comparação da metodologia aplicada e outras atividades da disciplina.

Em uma análise mais abrangente, identifica-se que o jogo "Hóquei no campo elétrico" obteve melhores avaliações do que o jogo "Módulo de pouso lunar". Este padrão pode estar relacionado as próprias características das ferramentas, uma vez que o primeiro apresentava fases diferentes, que evoluíam em nível de dificuldade, propiciando maior desafio e diversão aos alunos. Além disso, a metodologia empregada durante as oficinas que aplicaram este jogo pode ter influenciado nos resultados, dado que o uso integrado de uma ferramenta extra chamada "Monte um átomo" estimulou a atenção dos discentes, que buscaram respondê-lo corretamente.

O outro jogo, diferentemente, apesar de dispor de um design mais completo, também exigia um entendimento mais complexo, característica que pode ter contribuindo para uma avaliação menos favorável. Quanto ao desafio e variação, a ferramenta não apresentava diversificação em níveis, o que, em algumas perspectivas, diminui a sensação de engajamento e relevância para os alunos. 


\section{CONSIDERAÇÕES FINAIS}

A experiência demonstrada no presente artigo buscou destacar a relevância do uso de algumas ramificações da ciência da computação para educação por meio da realização de oficinas voltadas para o ensino da física, fundamentadas em uma metodologia baseada na utilização de jogos.

Mediante os resultados encontrados, é possível identificar que as atividades realizadas propiciaram uma experiência positiva para os alunos, uma vez que estes foram apresentados a um contexto fora do habitual para o ensino da disciplina. Além disso, consegue-se ainda reconhecer perspectivas animadoras dentro da ideia de aprendizagem, posto que, com base na visão dos próprios discentes, os recursos utilizados favoreceram o desenvolvimento de aspectos como diversão e desafio, os quais acarretam numa participação mais expressiva nas aulas.

Ainda assim, mesmo considerando que a experiência colaborou amplamente para a compreensão dos conceitos físicos pelos alunos, identifica-se a necessidade de experimentos mais completos, que envolvam uma maior quantidade de participantes e diferentes conteúdos, de modo a observar os impactos da metodologia a longo prazo e sanar as limitações encontradas durante o experimento. Consequentemente, consegue-se distinguir espaço para projetos futuros, inclusive com outras disciplinas regulares.

\section{REFERÊNCIAS}

[1] Bordini, A. et al. (2017) "Pensamento Computacional nos ensinos fundamental e médio: uma revisão sistemática”, In: Congresso brasileiro de informática na educação, 6., 2017, Recife. Anais do XXVIII Simpósio Brasileiro de Informática na Educação. Recife: Sociedade Brasileira de Computação. p. 123-132.

[2] Costa, T.; Verdeaux, M. (2016) “Gamificação de materiais didáticos: uma proposta para a aprendizagem significativa da modelagem de problemas físicos", Experiências em ensino de ciências, Brasília, v. 11, n. 2, p.60-105.

[3] Hainey, T., Connolly, T. M., Boyle, E. A., Wilson, A., e Razak, A. (2016) "A systematic literature review of games-based learning empirical evidence in primary education". Computers \& Education, 102, 202 - 223, 2016. DOI: 10.1016/j.compedu.2016.09.001

[4] Kapp, K. M. (2012) The Gamification of Learning and Instruction: Game-based Methods and Strategies for Training and Education, 1st Edition, Pfeiffer.

[5] Martins, R.; Reis, R.; Marques, B. (2016) "Inserção da programação no ensino fundamental: Uma análise do jogo Labirinto Clássico da Code.org através de um modelo de avaliação de jogos educacionais", In: Congresso brasileiro de informática na educação, 5., 2016, Uberlândia. Anais do XXII Workshop de Informática na Escola. Uberlândia: Sociedade Brasileira de Computação, p. 121-130.

[6] Medeiros, A.; Medeiros, C. F. (2002) "Possibilidades e limitações das simulações computacionais no ensino da física”, Revista Brasileira de Ensino de Física, São Paulo, v. 24, n. 2, p.77-86.

[7] Medeiros, T. et al. (2018). "Um Mapeamento e Avaliação de Jogos Digitais para Ensino de Matemática”. Anais do III Congresso Sobre Tecnologias na Educação (CTRL+E 2018), Fortaleza/CE, p. 381 - 391.

[8] Pietruchinski, M., Coelho Neto, J., Malucelli, A. e Reinehr, S. (2011), “Os jogos educativos no contexto do SBIE: uma revisão sistemática de literatura". In: Congresso brasileiro de informática na educação. Anais do XXII Simpósio Brasileiro de Informática Educacional. Aracaju/SE: Sociedade Brasileira de Computação, p.476-485.

[9] Prensky, M. (2012). Aprendizagem Baseada em Jogos Digitais. São Paulo: Senac.

[10] Ramos, H. (2014) "Pensamento Computacional na Educação Básica: uma proposta de aplicação pedagógica para alunos do quinto ano do Ensino Fundamental do Distrito Federal”. Monografia (Licenciatura) - Curso de Computação, Departamento de Ciência da Computação, Universidade de Brasília, Brasília.

[11] Santana, A. et al. (2017) “Tem Ideia na Rede: Inserindo o Pensamento Computacional na Rede Municipal de Ensino", In: Congresso brasileiro de informática na educação, 6., 2017, Recife. Anais XXIII Workshop de Informática na Escola. Recife/PE: Sociedade Brasileira de Computação, p. 1032-1041.

[12] Savi, R. et al. (2010) "Proposta de um Modelo de Avaliação de Jogos Educacionais", Renote, Porto Alegre, v. 8, n. 3, p.1-12.

[13] Viana, L. H. et al. (2015) “Tecendo novos métodos de ensino e avaliação: utilizando o Game Angry Birds Rio no ensino de Física", In: Encontro de iniciação à docência da UEPB, 5., 2015, Campina Grande. Anais... Campina Grande: Realize. 
ANEXO A - PRÉ-TESTE RELATIVO AO CONTEÚDO DE CINEMÁTICA E LEIS DE NEWTON

TESTE AVALIATIVO

Turma:

10 que você entende por lei da inércia?

2 - 0 que são vetores?

3 - Podemos sempre somar(subtrair) dois vetores?

4 - 0 que é velocidade e o que é aceleração?

5 - Pode-se representar velocidade e aceleração com vetores? Justifique.

6 - A aceleração e a gravidade são a mesma coisa? Justifique. 
ANEXO B - PRÉ-TESTE RELATIVO AO CONTEÚDO DE ELETROSTÁTICA E CONSTITUINTES DA MATÉRIA

\section{TESTE AVALIATIVO}

Turma:

1 Quais são os constituintes da matéria?

20 que de fato é importante para diferenciar um elemento da tabela periódica de outro?

3 - Para sabermos a massa atômica o que deve ser levado em consideração?

4 - 0 que é um íon?

5 - Teoricamente, o que é preciso para transformar $\mathrm{Pb}$ em $\mathrm{Au}$ ? 


\section{ANEXO C - QUESTIONÁRIO UTILIZADO PARA AVALIAÇÃO DOS JOGOS \\ AVALIAÇÃo DO JOGO}

O seguinte questionário tem por objetivo identificar a sua percepção sobre o jogo utilizado. Na tabela apresentada abaixo existem afirmações relacionadas ao uso da ferramenta, as quais devem ser avaliadas de acordo com sua experiência. Desse modo, você deve demonstrar sua concordância ou discordância quanto ao conteúdo das afirmações por meio da seguinte escala.

(-2) Discordância total/ (-1) Discordância/ (0) Nem concorda, nem discorda/ (1) Concordância/ (2) Concordância total

\section{AFIRMACÃO}

É por causa do meu esforço pessoal que consigo avançar no jogo.

Estou satisfeito, porque sei que terei oportunidades de utilizar na prática coisas que aprendi no jogo.

Ao passar pelas etapas do jogo senti confiança de que estava aprendendo. Foi fácil entender o jogo e começar a utilizá-lo como material de estudo.

O conteúdo do jogo está conectado com outros conhecimentos que já possuía.

0 funcionamento deste jogo está adequado ao meu jeito de aprender.

0 conteúdo do jogo é relevante para os meus interesses.

A variação do jogo ajudou a me manter atento.

Houve algo interessante no início do jogo que capturou minha atenção.

O design do jogo é atraente.

Tive sentimentos positivos de eficiência no desenvolver do jogo.

Consegui atingir os objetivos do jogo por meio das minhas habilidades.

Gostaria de utilizar este jogo novamente.

Eu recomendaria este jogo para meus colegas.

Quando interrompido, fiquei desapontado que o jogo tinha acabado.

Me diverti com o jogo.

O jogo evolui num ritmo adequado e não fica monótono, oferecendo novos obstáculos e situações.

Este jogo é adequadamente desafiador para mim, as tarefas não são muito fáceis nem muito difíceis.

O jogo promove momentos de cooperação ou competição entre as pessoas que participam.

Me diverti junto com outras pessoas.

Pude interagir com outras pessoas durante o jogo.

Me senti mais no ambiente do jogo do que no mundo real, esquecendo do que estava ao meu redor.

Eu não percebi o tempo passar enquanto jogava, quando vi o jogo acabou.

Temporariamente esqueci as minhas preocupações do dia-a-dia, fiquei totalmente concentrado no jogo.

0 jogo foi eficiente para minha aprendizagem, em comparação com outras atividades da disciplina.

O jogo contribuiu para a minha aprendizagem na disciplina.

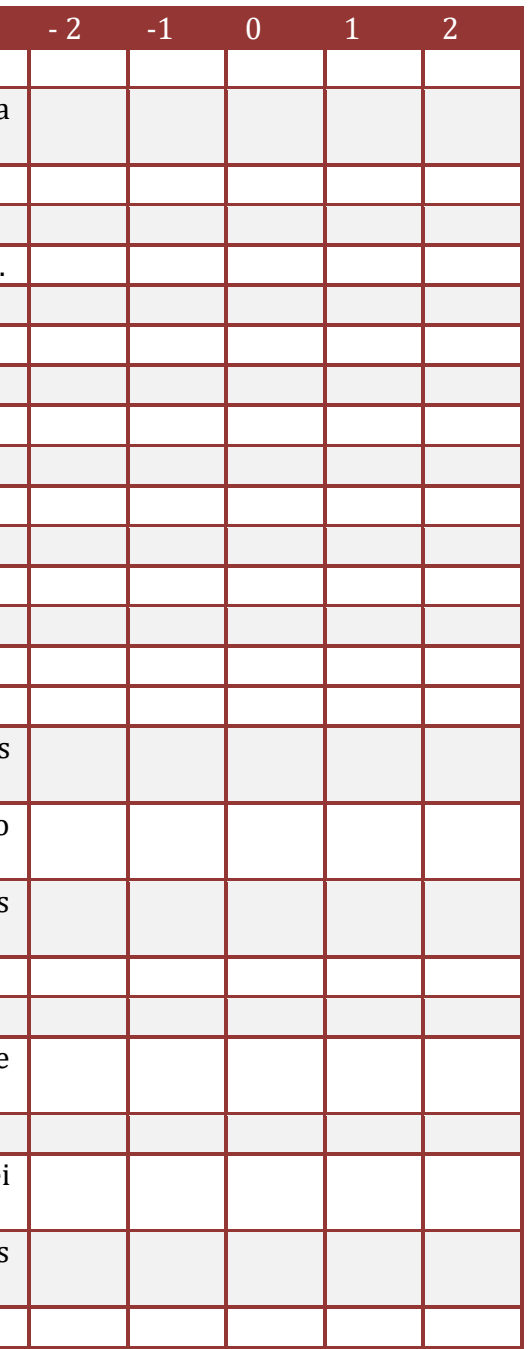




\section{Capitulo 17}

O uso da História da Matemática na busca de uma aprendizagem significativa no ensino de Matemática

\section{Rodrigo Corsino Lopes}

Resumo: Este Artigo trata sobre a importância do uso da História da Matemática no ensino da Matemática, visando uma aprendizagem significativa dos alunos e reconhecendo os principais pontos positivos apresentados nesta metodologia a partir de uma pesquisa básica em diversas obras teóricas, sempre ponderando a interação alunoprofessor no contexto do ensino aprendizagem. É realizada uma análise da prática pedagógica utilizada por muitos professores, baseada em definições, exemplos e exercícios que refletem a total passividade dos alunos, que ficam esperando que $o$ professor lhes diga quais os passos a serem realizados, e, caso venha ser solicitada alguma atividade diferente, são incapazes de interpretar e fazer sozinhos. Mas, através das orientações da Educação Matemática voltadas para a tradução da realidade e construção dos conceitos de modo significativo, o professor pode, com múltiplos olhares sobre a História da Matemática, despertar o interesse dos seus alunos.

Palavras-chave: Matemática. História da Matemática. Aprendizagem Significativa. 


\section{INTRODUÇÃO}

Considerando que a Matemática vem evoluindo ao longo de séculos com os esforços de muitos pensadores conhecidos e anônimos, quando se trata de repassar o conhecimento por eles desenvolvido, os professores precisam buscar meios e métodos que possam auxiliá-los a alcançar tais objetivos.

Buscar uma alternativa para atrair a atenção dos alunos em um mundo tão conectado se tornou um desafio, diversas metodologias são desenvolvidas e implantadas visando uma aprendizagem eficaz, satisfatória e significativa. No ensino da Matemática não é diferente, no entanto, algumas perguntas são feitas há muito tempo por grande parte dos alunos e o professor deve estar atento a elas. Uma dessas perguntas é: “- De onde surgiu isso?".

Para responder esse questionamento, o professor precisa estar sempre em busca de conhecer e compreender tanto os conteúdos quanto a história por trás da descoberta que trouxe à tona o que ele está ensinando. Eis a importância de conhecer a História da Matemática e aplicar no contexto escolar, buscando sempre uma aprendizagem significativa por parte dos alunos.

Desta maneira, será aplicada uma pesquisa básica para gerar um conhecimento útil para quem possa querer intervir e aplicar em sala de aula, pois não prima gerar lucro ou aplicação imediata do conhecimento produzido e sim buscar trazer uma alternativa de intervenção em sala de aula. Os procedimentos técnicos empregados serão de analisar, bibliograficamente, diversas literaturas a respeito do uso de História da Matemática.

\section{A HISTÓRIA DA MATEMÁTICA NA BUSCA DE UMA APRENDIZAGEM SIGNIFICATIVA NO ENSINO DE MATEMÁTICA}

Pensar em uma aula de Matemática fundamentada na história, não só nos algoritmos e formas geométricas, mas também, no significado do que será estudado desde sua essência, é o que vai fazer os conteúdos vistos no livro didático com toda sua teoria fazer sentido, construindo o conhecimento gradativamente de forma coesa e diferenciada.

No entanto, tudo depende de como o professor vê sua prática em sala de aula e como ele vê a necessidade de trazer um contexto para o que ele vai ensinar aos alunos, pois tudo que o aluno construir na escola será levado por ele para vida toda, de maneira que, não são apenas conteúdos ministrados pelo professor e sim pontos de vistas sobre determinado conteúdo.

Mol (2013), na apresentação de sua obra, faz uma reflexão sobre a construção do conhecimento e o modo de pensar na visão dos pensadores gregos:

Os pensadores da Grécia Clássica, ao racionalizar a compreensão de quantidades e formas, estruturaram a matemática como modo de pensar. Ela, ao longo da história, teve papel central na maneira como o homem entende o mundo - o que induziu os gregos a tratá-la como a essência do conhecimento. (MOL, 2013, p. 9).

Desta forma, quando se deixou de ter como importante ensinar ou até mesmo analisar não somente o contexto dos conteúdos matemáticos ministrados em sala de aula, mas a história que existem por traz deles? Tal pergunta não pode ser respondida por apenas um professor, pois é uma prática de anos, mas a mudança só poderá acontecer mediante a vontade de cada professor de mudar a realidade dos alunos.

É então que a História da Matemática pode ser uma alternativa eficaz na busca de uma aprendizagem significativa, pois faz emergir nos alunos uma vontade de conhecer, analisar e aprender cada vez mais, tal como os antigos pensadores, que buscavam os significados para explicar a interação entre a natureza e a Matemática, gerando desta forma as mais diversas ciências. 
Nos Parâmetros Curriculares Nacionais para Matemática, que norteia o ensino da disciplina no país, é mostrada a importância do uso da História da Matemática para responder indagações básicas que, porventura, possam surgir no decorrer do processo de ensino aprendizagem, tais como pode ser lido neste trecho:

Em muitas situações, o recurso à História da Matemática pode esclarecer ideias matemáticas que estão sendo construídas pelo aluno, especialmente para dar respostas a alguns "porquês" e, desse modo, contribuir para a constituição de um olhar mais crítico sobre os objetos de conhecimento. (BRASIL, 1997, p. 34).

Deste modo, ao descrever a importância do uso da História da Matemática como recurso didático, visando elevar o nível das aulas, tornando-as mais motivadoras e desafiadoras, Lopes e Ferreira (2013) afirmam que:

[...] ao perceber a fundamentação histórica da matemática, o professor tem em suas mãos ferramentas para mostrar o porquê de estudar determinados conteúdos, fugindo das repetições mecânicas de algoritmos. (LOPES; FERREIRA, 2013, p. 77).

Logo, ao propor a ruptura com o velho modelo de ensino tradicional, preso à repetições de fórmulas e em decorar métodos para resolver cálculos específicos e sem significado, o professor precisa ter em mente que a partir daquele ponto ele passará a ter responsabilidade em gerenciar o que for repassado aos alunos.

Hannah Arendt reconhece que a responsabilidade do professor não é imposta de qualquer jeito, mas sim de maneira que ele possa exercer sua função de forma íntegra e com autoridade, como afirma em um trecho de sua obra:

A qualificação do professor consiste em conhecer o mundo e ser capaz de instruir os outros acerca deste, porém sua autoridade se assenta na responsabilidade que ele assume por este mundo. Face à criança, é como se ele fosse um representante de todos os habitantes adultos, apontando os detalhes e dizendo à criança: isso é o nosso mundo. (ARENDT, 1972, p. 239).

Diante desta autoridade imposta ao papel do professor e frente à necessidade imposta pela vontade de fazer a diferença na vida dos alunos, é que surge a importância da História da Matemática aplicada nas aulas, fazendo sempre o uso dela para contextualizar e fixar o que será tratado de maneira clara e simples.

Segundo Miguel e Brito, em um trecho de sua obra que retrata sobre o poder e os objetivos da História da Matemática no ensino aprendizagem, é evidente o quanto o que o professor ensina está em constante movimento e sempre em mudança, pois o meio em que estão inseridos os alunos interfere diretamente e de forma invisível nas respostas encontradas, como pode ser lido a seguir:

A história poderia auxiliar os futuros professores a perceber que o movimento de abstração e generalização crescentes por que passam muitos conceitos e teorias em matemática não se deve, exclusivamente, a razões de ordem lógica, mas à interferência de outros discursos na constituição e no desenvolvimento do discurso matemático. (MIGUEL e BRIT0, 1996, p.4)

Diante de tais argumentos é inegável que não é o fato de usar a História da Matemática como metodologia que vai mudar todo o cenário da educação básica em nosso país, mas, investir em conhecimento para apresentar os conteúdos da melhor forma aos alunos, contextualizando e dando significado com fatos que fizeram parte da construção de tais conteúdos, contribuirá para o desenvolvimento de uma aprendizagem significativa.

Aprendizagem significativa a partir do método de Ausubel, que propôs sempre ancorar em conhecimentos prévios já existentes, todos os novos conceitos que serão estudados. Este processo é chamado de conceito subsunçor, e segundo Moreira (2001), em sua análise sobre este método, afirma que após a fase inicial dos estudos na pré-escola, o aluno já se encontra apto a receber novos conhecimentos, a partir daí, este processo jamais se encerrará, pois sempre haverá conhecimentos prévios há serem ancorados nos já existentes. 
Ao se propor unir uma aula fundamentada nos conceitos abstratos da Matemática com a história por trás do surgimento do mesmo e analisar os pontos de ancoragem para que tais conteúdos sejam compreendidos e assimilados pelos alunos, identifica-se onde está importância do uso da Historia da Matemática na busca de uma aprendizagem significativa, pois somente quando o professor tomar para si a responsabilidade do que é ensinado é que poderemos vislumbrar um horizonte possível de uma educação de qualidade e humana.

\section{CONSIDERAÇÕES FINAIS}

Ao longo do trabalho foi possível observar, nas diversas leituras feitas e nas ideias que os autores trouxeram, que o desenvolvimento do conhecimento dos alunos depende sempre da força de vontade que o professor tem em desenvolver ou aplicar metodologias de ensino que possam ser atrativas e instigantes para os alunos.

E por se tratar de um trabalho de metodologia básica com análise bibliográfica, foi possível fazer uma busca do porque que a História da Matemática poderia trazer ressignificação das aulas de Matemática, e que ao longo da pesquisa se mostrou necessário o professor buscar formas e maneiras diferenciadas de ensinar, eis aí a razão de uma pesquisa que visasse à difusão deste conhecimento.

Foi quando se observou que era praticamente unanime por parte dos teóricos que o uso da História da Matemática nas aulas traz um beneficio junto ao aprendizado significativo, pois dá sentido ao que estará sendo exposto pelo professor, buscando sempre ancorar em conhecimentos prévios o que será repassado aos alunos, pois para o professor pode ser apenas um conteúdo qualquer, mas para o aluno é um novo surgindo à sua frente.

E a partir do objetivo geral, que era visualizar a importância da aplicação da História da Matemática como metodologia ativa em sala de aula, foi que pôde-se observar não somente esta importância, mas também o quanto o trabalho do professor pode fazer diferença na vida dos alunos, já que tudo que ele fala mesmo que seja simples para ele, para aluno é muito importante.

Diante disso, cabe ao professor ser capaz de compreender o quanto ele poderá ser a diferença na vida escolar de seus alunos, mostrando caminhos, capacitando-os e guiando-os no caminho do conhecimento ou optar em apenas ser um mero coadjuvante, sem protagonismo e incapaz de ser lembrado por eles.

\section{REFERÊNCIAS}

[1] ARENDT, Hannah. Entre o passado e o futuro. São Paulo: Perspectiva, 1972.

[2] BRASIL. Secretaria de Educação Fundamental. Parâmetros curriculares nacionais: matemática / Secretaria de Educação Fundamental. - Brasília: MEC/SEF, 1997.

[3] LOPES, Lidiane Schimitz; Ferreira, André Luis Andrejew. Abakós, Belo Horizonte, v. 2, n. 1, p. 75-88, nov. 2013. Disponível em: <https://doi.org/10.5752/P.2316-9451.2013v2n1p75> Acesso em: 01 Janeiro 2020.

[4] MIGUEL, A. BRITO, A. J. A história da Matemática na formação do professor de Matemática. Cadernos CEDES História e Educação Matemática. Campinas (SP): Papirus, n 40, 1996.

[5] MOL, Rogério Santos. Introdução à história da matemática - Belo Horizonte: CAED-UFMG, 2013.

[6] MOREIRA, Marco Antônio; Masini, Elcie. Aprendizagem Significativa: a teoria de David Ausubel. 2 ed. São Paulo: Centauro. 2001. 


\section{Capítulo 18}

\section{Processos de transição no ensino de matemática: o caso da passagem do cálculo de uma a mais variáveis}

\section{Sandro René Cunha}

\section{Márcia Maria Fusaro Pinto}

Resumo: Neste artigo trazemos reflexões sobre transições no ensino da matemática internas a uma mesma instituição, considerando como contextos distintos o ensino nas diversas disciplinas do currículo de um curso de Matemática. Em particular o foco é na transição do ensino de cálculo de uma variável para o de mais variáveis, inserindo a pesquisa no campo da Educação Matemática no Ensino Superior8. O objetivo é identificar e analisar analogias e diferenças entre os conceitos para o entendimento do conteúdo de cálculo fragmentado em diferentes disciplinas. Desdobramentos da investigação nos levam a refletir de modo mais amplo sobre os modos com que podemos entender o fenômeno da transição interna/externa no ensino de matemática, e como podemos analisar as transições internas no ensino da matemática na universidade.

Palavras-chave: cálculo de várias variáveis; transição; educação matemática no ensino superior; tecnologias. 


\section{APRESENTAÇÃO}

Nossa parceria como pesquisadores se inicia em 2011, quando o primeiro autor, aluno de Mestrado oferecido pelo Programa de Ensino de Matemática do Instituto de Matemática da Universidade Federal do Rio de Janeiro (PEMAT/IM/UFRJ) escolheu dentre os temas apresentados pelas linhas de pesquisa em Ensino de Matemática para o desenvolvimento da dissertação, ser orientado pela segunda autora. Desde então temos caminhado juntos, compartilhando o espaço da sala de aula como aluno e professor, e como professores, e desenvolvendo nossa pesquisa.

A dissertação de mestrado Uma Análise das Provas Unificadas de Cálculo 1 do Curso de Engenharia da UFRJ $(2013)^{9}$ é um dos resultados desta parceria, e parte de seus resultados estão publicados em Cunha e Pinto (2014). A investigação teve por foco entendermos como o conhecimento é reproduzido a partir de uma prática específica como um sistema unificado, segundo aspectos típicos da cultura de uma turma de Cálculo I. Para isto, analisamos os enunciados e as soluções das questões de provas de Cálculo I disponibilizadas online por uma equipe de professores, buscando descrever os conhecimentos sobre limites, continuidade e derivada que vêm sendo considerados relevantes para a formação esperada dos alunos de turmas em que o modelo de prova unificada é adotado.

Na ocasião, buscamos descrever os conhecimentos sobre limites, continuidade e derivada que vêm sendo considerados relevantes para a formação esperada dos alunos de turmas em que o modelo de prova unificada é adotado (CUNHA, 2013). Para tal, adotamos a perspectiva da Teoria Antropológica do Didático, de Yves Chevallard (1999), da organização matemática que observamos. Pudemos verificar que o bloco técnico é altamente valorizado e, mesmo que seja possível identificarmos aspectos tecnológicos, entendidos como reflexões sobre a técnica, nas soluções divulgadas, não nos parecia haver uma preocupação em deixá-la visível, mas sim em mantê-la em um segundo nível de importância em relação à técnica.

Aproximando-nos em nossas concepções sobre ensino de algumas noções do Pensamento Complexo, trazidas de Edgar Morin (1990), entendemos que no ato de aprender "é preciso substituir um pensamento que isola e separa por um pensamento que distingue e une"(MORIN, 2003, p.87). 0 texto que apresento a seguir traz nossas reflexões iniciais sobre a transição no ensino do Cálculo de funções de uma a mais variáveis, decorrente de nosso interesse em abordagens que integrem e promovam uma boa articulação ao re-significar os conceitos de uma a mais variáveis; que reconstruam o conhecimento anterior colocando ordem, clareza, distinção e precisão no novo tema. Almejamos um saber não fragmentado, não reducionista, reconhecendo que qualquer conhecimento está inacabado, incompleto, havendo possibilidade de ser questionado, interrogado e reformulado. Compartilhamos com o filósofo francês que as "verdades profundas, antagônicas umas às outras, eram para mim complementares, sem deixarem de ser antagônicas" (MORIN, 2005, p.7).

Assim, tencionamos um estudo focando uma transição, interna ao ensino de Cálculo, entre o conteúdo de funções de uma a mais variáveis, analisando as analogias e diferenças entre os conceitos para o entendimento do Cálculo esfacelado em diferentes disciplinas. Em outras palavras, queremos investigar a aprendizagem dos conceitos matemáticos na passagem de uma etapa de seu ensino a outra. Este novo projeto tem relação com o anterior, desenvolvido em meu mestrado, uma vez que, ao analisarmos as avaliações em Cálculo I, produzimos resultados que podem nos ajudam a entender possíveis dificuldades associadas à passagem do Cálculo Diferencial de Funções de Uma Variável ao de Duas ou Mais Variáveis. Por exemplo, ao valorizar os procedimentos predominantemente técnicos nos gabaritos das provas, o conhecimento tecnológico assumiu um papel exterior, ficando à margem do conteúdo de importância do Cálculo 1. Com isso, podemos atribuir ao sistema de prova unificada de Cálculo 1, uma marcante característica técnica. Sendo mais específicos, podemos mencionar sobre dois momentos mais frequentes nas provas e em suas resoluções. Em um primeiro, a técnica utilizada dispensa qualquer outro comentário explicativo como resposta para a questão; nesse sentido notamos uma forte tendência auto explicativa (auto tecnológica) assumida por esta instituição. Em outro momento, os objetos matemáticos presentes nas soluções dos problemas apresentam uma forte tendência para integrar elementos tecnológicos às técnicas, onde os discursos apresentam uma dupla função: técnica e tecnológica. Nesses casos, podemos identificar no seu desenvolvimento, maneiras de encontrar a solução e também de justificá-la.

\footnotetext{
9 Uma versão deste trabalho encontra-se disponível em https://wp.ufpel.edu.br/xxiebrapem/files/2018/10/gd4_sandro_cunha.pdf
} 
Em síntese, o uso de procedimentos técnicos foram tomados como suficientes para esclarecer as soluções dos problemas, dispensando comentários mais detalhados que pudessem explicar os motivos pelos quais se chegou ao resultado, bem como ao ensino e aprendizagem da disciplina de Cálculo em sua totalidade. Este cenário configura o conhecimento esperado pela Instituição que os alunos devem aprender, explicitando pontos frágeis na ressignificação dos conceitos, que será requerida na passagem de uma para duas variáveis no estudo de funções.

No momento em que escrevemos este texto, refletimos sobre os modos com que os resultados de pesquisas relacionadas a problemas sobre a transição de um curso no ensino superior de matemática a outro, ou do ensino médio para o ensino superior, referem-se a analogias; e de que modos identificam e descrevem uma ruptura, que intervêm na forma como o conhecimento é construído no âmbito das práticas associadas; em particular, aquelas associadas a transições internas ao cálculo. Para a redação deste artigo, buscamos responder aos seguintes questionamentos

1) De que modos podemos entender o fenômeno da transição interna/externa no ensino de matemática?

2) De que modos podemos analisar as transições internas no ensino da matemática na universidade?

Para isso, trazemos os pressupostos sócio-filosóficos em educação que fundamentam a perspectiva que adotamos. Em seguida passamos às nossas leituras mediante alguns trabalhos correlacionados. Finalizamos com nossas reflexões sobre as leituras realizadas, buscando respostas para as questões anteriormente colocadas.

\section{UM OLHAR COMPLEXO PARA OS PROBLEMAS DA TRANSICYÃO NO ENSINO}

Nessa pesquisa adotamos a noção de Pensamento Complexo (MORIN, 1990) como perspectiva teórica para investigar o processo de transição nos diversos cursos de Cálculo, pressupondo que é preciso reorganizar os saberes para compreendê-los em sua totalidade.

De um ponto de vista macro, a Universidade enfrenta muitos desafios; dentre eles, uma primeira adversidade diz respeito

[...]’a pressão superadaptativa que força a conformar o ensino e a pesquisa às demandas econômicas, técnicas, administrativas do momento, a se conformar aos últimos métodos, às últimas receitas no mercado, a reduzir o ensino geral, a marginalizar a cultura humanista. (MORIN, 2003, p.25).

Merece destaque um outro obstáculo para a educação superior, que se deve à

[...] compartimentação e a disjunção entre cultura humanista e cultura científica, acompanhadas pela compartimentação entre as diferentes ciências e disciplinas. A não comunicação entre as duas culturas determina graves consequências para ambas. (idem, ibidem).

A medida em que o discurso educacional torna-se refém das demandas do liberalismo do mercado financeiro e poder econômico, há supressão da comunicação entre as culturas cientificas e humanistas, reforçada pela enorme dificuldade em manter-se algum ponto institucional de fronteira entre essas disciplinas. 0 que provoca graves consequências tanto para uma e outra, posto que o propósito de uma encontra na extensão de objetos de interesse da outra, a sua real finalidade para a sociedade humana.

No que se refere ao espaço da sala de aula, a reestruturação do pensamento para o ensino proposta por Edgar Morin é multidisciplinar e muito mais ampla do que pode alcançar a do nosso estudo sobre a transição do cálculo de uma a várias vaiáveis. Porém, apesar de nosso vislumbrar ser restrito se comparado à teoria do sociólogo, queremos ao menos "plantar uma semente" de inspiração, que guie nossa reflexão sobre os obstáculos na aprendizagem ao longo da trajetória de um curso ou tópico a outro em matemática superior; em particular, sobre a transição de um cálculo a outro de duas variáveis. Para este último, retomamos os trabalhos de Alves (2011, 2012 e 2013), que apresentam estudos referentes a tópicos de Cálculo de Várias Variáveis que admitem uma interpretação imediata no contexto do Cálculo de Uma Variável e possíveis ligações conceituais evidenciadas pela visualização em softwares com recursos gráficos. 
Na seção seguinte resumimos alguns resultados da pesquisa produzida sobre o tema em estudo, que é a educação matemática no ensino superior e as transições entre os diferentes níveis de ensino, destacando algumas abordagens e métodos que têm relação com a investigação que estamos propondo, e que está vinculada à nossa linha de pesquisa do PEMAT.

\section{ALGUMAS QUESTÕES DE INTERESSE E RESULTADOS DE PESQUISA SOBRE AS TRANSIÇõES NO ENSINO DE MATEMÁTICA}

Interessados em outras pesquisas que envolvem situações de transição em Ensino de Matemática, entendemos que os estudos a respeito da transição do ensino médio para o ensino superior, que identificamos como transição externa por evolver duas instituições de ensino diferentes, têm despertado interesse dos pesquisadores na área de educação matemática. Um dos motivos é o desejo de conhecer "as dificuldades, cada vez mais graves, apresentadas pelos alunos ingressantes, na primeira disciplina em Cálculo" (NASSER, SOUZA e TORRACA; 2012). 0 foco, nestes trabalhos, é na aprendizagem e os alunos são os sujeitos da maioria das pesquisas que vem sendo desenvolvidas. Para os autores Nasser, Souza e Torraca, um dos problemas de aprendizagem relacionados ao baixo desempenho dos alunos de Cálculo, está na compreensão e na construção de gráficos. Em pesquisa realizada sobre a própria prática, Nasser (2009) aponta que "as dificuldades se devem, principalmente, à falta de preparação prévia", e destaca algumas ações dos professores que podem ajudar nesse sentido, tais como "desenvolver estratégias de ensino apropriadas, de acordo com os estilos de aprendizagem dos alunos, em particular, enfatizando exercícios sobre transformações de gráficos" (NASSER, 2009, p. 54). Dando prosseguimento ‘a sua investigação, a pesquisadora também verificou que a mesma estratégia pode ajudar no desempenho dos alunos em Cálculo II, reforçando que tal procedimento pode ser usado para superar dificuldades na compreensão de funções de duas variaveis. Por exemplo, no caso de gráficos de superfícies, como paraboloides, cones, cilindros e esferas, a construção por meio de transformaç̃̃es a partir de superfícies básicas também facilita a identificação e o entendimento do assunto (NASSER, 2009, p. 52).

Uma outra vertente de pesquisa trata a problemática de um movimento de transição interna `a uma mesma instituição de ensino superior de matemática, e foca o momento de mudança do Cálculo para Análise.

No caso do ensino de Cálculo, as ideias inicialmente propostas podem ser amparadas por uma abordagem sensorial das definições e demais proposições. Em seu livro How Humans learn to think mathematically, publicado em 2013, o pesquisador David Tall caracteriza três matemáticas: a matemática prática, a matemática teórica e a formal. Para isto ele leva em conta a epistemologia dos objetos estudados em cada uma delas e "a natureza da argumentação envolvida" (p.20). 0 que o autor denomina por matemática prática refere-se ao "reconhecimento e descrições de ideias no espaço e forma e a experiência prática da aritmética com base na familiaridade crescente com as operações e com os efeitos dessas operações". (p.20) A coerência é chave na elaboração de justificativas matemáticas. As práticas matemáticas na escola fundamental tem características como estas; e explicam em parte os conflitos enfrentados pelos alunos na transição para as práticas matemáticas que são principalmente teóricas, quando saem da escola e ingressam na universidade. No ensino superior, a matemática caracteriza-se como teórica, e envolve "o uso das propriedades observadas como definições, que podem ser usadas como base da dedução e da prova" (p.20). Por exemplo, em nosso primeiro contato com as operações aritméticas reconhecemos a lei comutativa da adição enquanto manipulamos elementos de conjuntos e números específicos. Mais tarde, re-significamos a coerência percebida anteriormente como uma identidade algébrica, que fica incluída como uma regra dentre outras que denominamos 'regras da aritmética'. Baseados nestas últimas, passamos a deduzir outros fatos usando manipulações algébricas. O Cálculo que ensinamos nas universidades resultam de práticas que exigem argumentação matemática teórico. Nas próprias palavras de Tall, o ingresso em cursos de matemática nas universidades "envolve uma transição significativa: da descrição à definição, do convencimento à prova de uma maneira lógica com base nas definições...... é a transição da coerência da matemática elementar para a consequência da matemática avançada..." (Tall , 1991, p.20). Este último parágrafo caracteriza diferenças na natureza dos objetos matemáticos reconhecidos na universidade quando contrastados com aqueles com os quais trabalhamos na escola.

No caso da Análise Real, "todos os conceitos recebem um tratamento formal desde o início, ao se definir formalmente o conjunto real” (BERGÉ, 2010). A Análise Real é inserida em práticas que Tall (2013) identifica como matemática formal. Retomando as palavras de Otero-Garcia (2012) sobre a transição dos Cálculos para a Análise Real, acrescentamos ainda que 
[...] para Pinto, o ensino do Cálculo é fundamentalmente diferente do de Análise, porque, enquanto nesse fundamentam-se os princípios axiomáticos e sistemáticos, com definições formais, naquele são enfatizados aspectos computacionais e de manipulação simbólica, visando obter uma resposta final. Essa diferença acarretaria num grande impacto na transição do cálculo para a análise. (p.756).

Deste modo, descrever, definir, justificar e explicar expõem variações explícitas nas práticas matemáticas que ocorrem nos diversos espaços institucionais que vivenciamos em nosso percurso acadêmico e que agora estamos investigando. Em outras palavras, relações institucionais com o objeto matemático em cada caso são estabelecidas de modo diferente. Em síntese, o aprendizado nas universidades exige dos alunos mudanças em relações com vários objetos que eles experimentaram anteriormente na escola, ou em momentos anteriores ao longo próprio curso na universidade (Chevalard, 1999)

A relevância do tema escolhido nesta pesquisa é reafirmada em inúmeros artigos publicados em canais de divulgação de pesquisas em educação matemática nacionalmente e internacionalmente. Diante da vasta literatura de pesquisas que, de alguma forma, abordam o tema de transição ou da variedade de resultados divulgados mundialmente sobre o desempenho de alunos e professores em periódicos de educação, as investigações em ensino assumem uma extensa e complexa relação envolvendo, entre outras coisas, a problemática da passagem de um estágio a outro do ensino.

O caso da transição do Cálculo de uma a duas variáveis estudado por Alves (2011), por se tratar de uma situação que reflete a respeito de duas possibilidades: transição interna e externa. No que segue, trazemos seus resultados.

\subsection{PROBLEMAS NA TRANSIÇÃO ENTRE OS CÁLCULOS}

$\mathrm{Na}$ literatura de pesquisa sobre o tema que queremos investigar encontramos os trabalhos de Alves (2011) referindo-se `a transição interna do Cálculo de uma Variável para o Cálculo a Várias Variáveis. Em sua pesquisa, o autor procura identificar e descrever categorias para o raciocínio intuitivo, adotando a perspectiva de Fishbein (1987). Esse último aponta a dissonância de significados atribuídos ao termo "conhecimento intuitivo", discutindo as duas formas de cognição: Intuitivas e Lógicas. Estas são exploradas em fases previstas por metodologia conhecida como sequência Fedathi (Borges Neto, 2001), uma sequência didática que se baseia no ensino/aprendizagem por meio de resolução de problemas, conforme explorados por Polya nos anos 70. Em sua concepção, são categorizados os níveis de desenvolvimento do pensamento lógico que uma pessoa utiliza quando é solicitada a resolver um problema, conforme as seguintes fases: tomada de posição, maturação, solução do problema e prova.

Como complemento ao aporte teórico, Alves (2011) utiliza uma visão da Teoria dos Registros de Representação Semiótica (DUVAL, 1991, 1995a). Segundo Alves(2011), há poucos estudos no Brasil e no exterior acerca do Ensino e Aprendizagem do Cálculo Diferencial e Integral a Várias Variáveis, principalmente com ênfase em descrição interna em Cálculo. Em seu estudo empírico, este mesmo autor identificou as dificuldades dos estudantes para desenvolver e entender argumentos lógico-formais. Porém, os conceitos apresentados no Cálculo a Várias Variáveis, que possuem uma fundamentação formal em Análise Realn, são explorados, de modo predominante, no espaço real R³ (ALVES, 2012, p.7).

Dos resultados dos estudos realizados, Alves (2012) afirma que

[...] podemos discutir situações do Cálculo de Várias Variáveis que admitem uma interpretação imediata no contexto do Cálculo de Uma Variável e possíveis ligações conceituais evidenciadas pelo CAS Maple. Tal perspectiva que orienta uma abordagem didática pode favorecer o aluno no entendimento acerca da ligação conceitual, com apoio na representação gráfica, dos conceitos abordados tanto nos estudos das funções tratadas em Cálculo I, como daquelas em Cálculo II. (p.5)

Ainda no mesmo texto, o autor afirma que a percepção e o entendimento, a partir da visualização e da descrição geométrica dos objetos conceituais em Cálculo no $\mathbb{R}^{2}$ e no $\mathbb{R}^{3}$, podem atuar no sentido de proporcionar uma transição interna adequada em Cálculo. Para isso o autor utiliza os softwares Geogebra e o Cas Maple, como forma de um complementar as limitações do outro. No caso do Geogebra, o autor utilizou apenas a janela de visualização para o espaço $\mathrm{R}^{2}$, por outro lado, esse software oferece os recursos da geometria dinâmica. 
Desse modo, Alves (2012) considera que o papel do computador pode impulsionar a aprendizagem, por meio da "articulação de registros", em relação aos conceitos envolvidos na transição interna do cálculo. Proporcionando a possibilidade de realizar um link conceitual envolvendo definições e teoremas que, além de demandar um menor período de estudos, com o apoio tecnológico, o aluno poderá depreender a relação conceitual pertinente aos dois conteúdos.

\section{REFLEXÕES SOBRE A TRANSIÇÃO NO ENSINO DO CÁLCULO}

Para finalizar, trazemos as nossas reflexões sobre pesquisas que abordam as transições entre espaços institucionais diversos, em especial, nos ambientes na universidade em que se ensina matemática. Nossa intenção é contribuir com o debate colocando duas questões que podem resultar em novas pesquisas:

1) Como analisar o fenômeno da transição interna/externa no ensino de matemática?

2) De que modos podemos analisar as transições internas no ensino da matemática na universidade?

Para respondê-las, buscamos novos olhares sobre aspectos trazidos em Alves (2012), atendo-nos `a matemática ensinada em cursos nas universidades.

Primeiro, mesmo que o tratamento de um estudo seja somente sobre problemas decorrentes da reestruturação dos conceitos em cálculo, por exemplo, relativos à passagem de funções de uma a mais variáveis, não podemos assumir de imediato que as dificuldades observadas em cálculo I nas pesquisas sobre a transição do ensino médio para o ensino superior deixaram de existir em um curso seguinte. Do mesmo modo, analisar a transição do Cálculo à Análise, diz respeito ao interesse em compreender as dificuldades que podem existir, decorrentes das próprias diferenças que fundamentam as duas disciplinas. A partir desses pressupostos tentamos revelar nossos entendimentos no que se refere `a transição interna no ensino da atemática.

De forma clara, fenômenos relacionados à transição no ensino tornam-se um objeto de investigação dos pesquisadores da área quando, na passagem de um estágio de transmissão de conhecimento ou prática de ensino à outra, emergem dificuldades ou deficiências no processo de ensino-aprendizagem.

Por outro lado, partimos do pressuposto de que não precisamos entender os movimentos de transição em Cálculo como dificuldades abissais se criarmos condições adequadas aos alunos para que possam transitar entre as diferentes práticas, legitimando-as e evidenciando limites e possibilidades nos instrumentos utilizados - o conhecimento usado para resolver questões sobre o conteúdo estudado. Conforme o caso, podemos discutir meios para transpor os efeitos negativos de uma transição no ensino, ou até mesmo desenvolver situações que sejam atraentes neste sentido, e que motivem um engajamento dos estudantes.

Por outro lado os problemas de transição, apesar de serem identificados na passagem de um estágio de transmissão de conhecimento ou prática de ensino à outra e quando observamos alguma dificuldade ou deficiência no processo de ensino-aprendizagem, propagam-se em nossas práticas em instituição cultural por causa ou efeito constituintes na própria formação da instituição. Temos por hipótese que dificuldades são em parte resultantes das organizações didáticas dos conteúdos no e do programa. Tais organizações correspondem `as relações institucionais com os objetos a serem estudados.

Em referência ao que Alves (2011) diz a respeito sobre a utilização da expressão "Transição Interna", não há explicação do seu significado para o ensino de Cálculo. Assumimos assim uma problemática da dinâmica de transição no ensino de matemática, que até o presente momento na literatura permanece apenas como uma expressão, usada para mencionar a respeito de alguma dificuldade de entendimento de um conceito em matemática, seja por conta das diferenças em relação às abordagens dos assuntos prévios ou ainda ao despreparo de alunos ou professores. Pouco nos detivemos de fato na análise das analogias possíveis que podem estar presentes entre práticas distintas, como no caso do cálculo de uma ou de várias variáveis.

Pensar tais analogias reorganiza nossos modos de pensar as transições entre disciplinas em um currículo, uma vez que disciplinas nada mais são que fragmentações de um conhecimento que pode ser totalizado. Em relação ao que Alves (2011) diz a respeito 0 esquema a seguir ilustra, ainda que de modo breve, nosso entendimento em relação a dois entendimentos possíveis para casos de transição no ensino de Cálculo. 
Figura 1. Diagrama das Transições interna e externa do Cálculo.

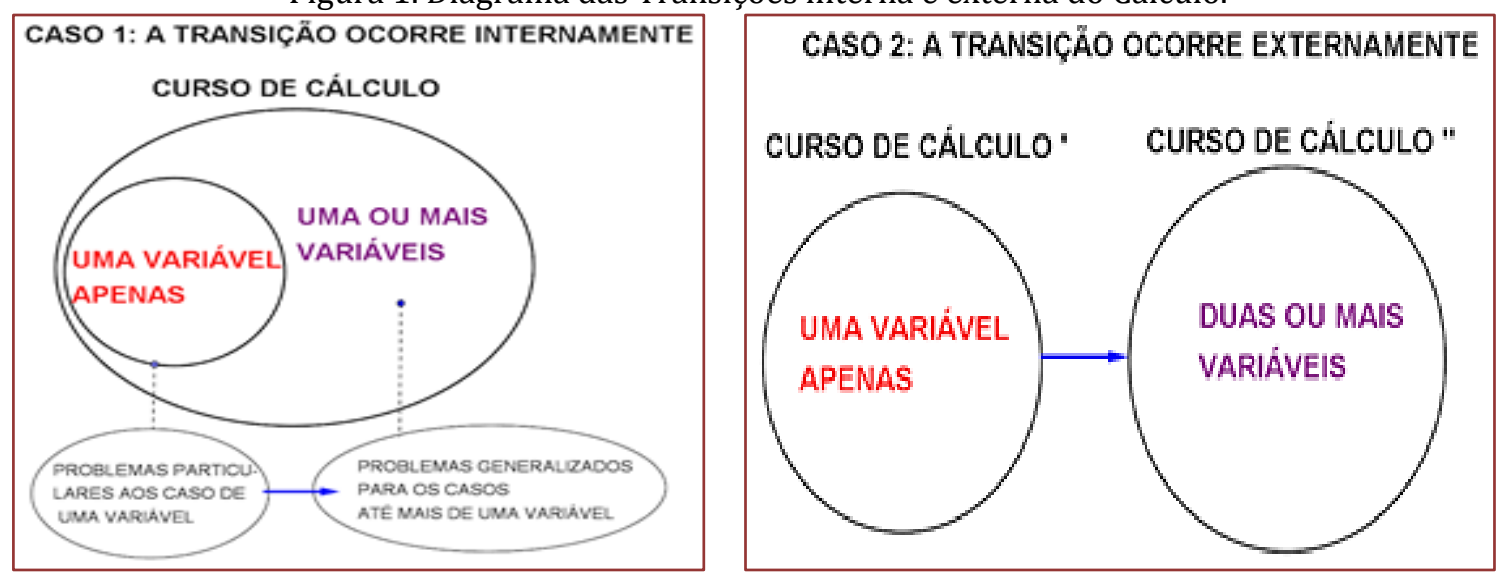

Fonte: arquivo pessoal

Uma segunda questão colocada em Alves (2011), quanto visualização e à descrição geométrica dos objetos conceituais em Cálculo no $\mathrm{R}^{2}$ e no $\mathrm{R}^{3}$, aponta para a utilização dos softwares Geogebra e o Cas Maple, como forma de um complementar as limitações do outro. Porém, atualmente, com os avanços dos recursos para a geometria dinâmica, podemos utilizar no software Geogebra, duas janelas (uma 2D e outra 3D) para construções geométricas e de gráficos de funções simultaneamente. A figura seguinte serve apenas para ilustrar um momento em que há duas janelas de visualização abertas no Geogebra, possibilitando construções geométricas nos dois casos.

Figura 2. Exemplo mostrando as duas janelas abertas na mesma tela do Geogebra, uma 2D e outra 3D.

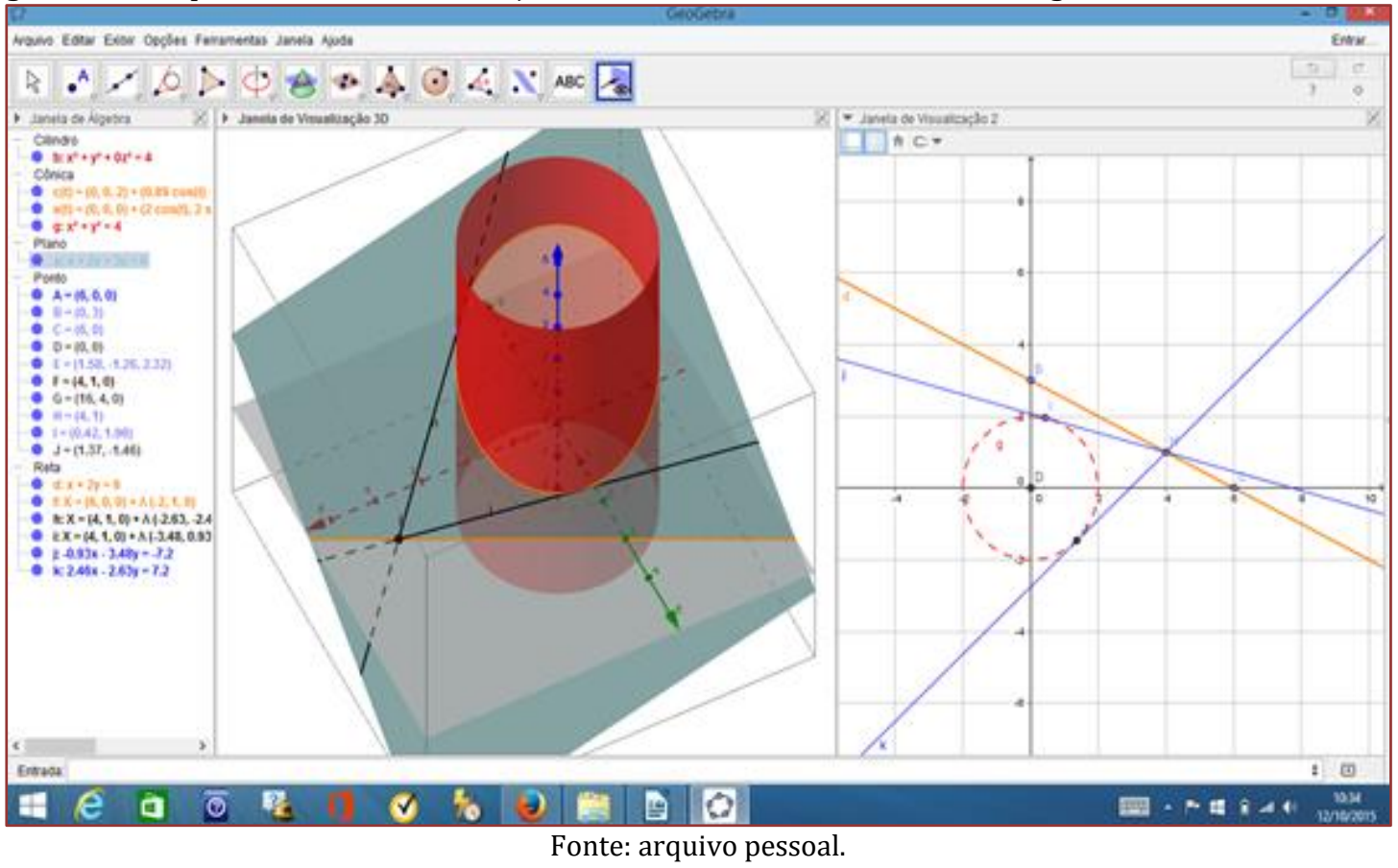

É importante estarmos atentos `as possibilidades visuais oferecidas pelas alternativas digitais que temos disponíveis. 


\section{REFERÊNCIAS}

[1] ALVES, Francisco Regis Vieira. Aplicações da sequência Fedathi na promoção do raciocínio intuitivo no cálculo a várias variáveis. 2011. Tese de Doutorado. Federal University of Ceará, Brazil.

[2] ALVES, Francisco Régis Vieira. Uma discussão do uso do Geogebra no contexto do Cálculo a Várias Variáveis. Revista do Instituto GeoGebra Internacional de São Paulo, v. 2, p. 5-19, 2013.

[3] ALVES, Francisco Régis Vieira. Transição Interna Do Cálculo: Uma discussão do uso do Geogebra no contexto do Cálculo a várias variáveis. In: Conferência Latino americana de Geogebra, 2012, Montevideo. Conferência Latinoamericana de Geogebra. Montevideo: Editora Universitária, 2012.v. 1. p. 1-8.

[4] BORGES NETO, Hermínio. et al. A Seqüência Fedathi como proposta metodológica no ensino-aprendizagem de Matemática e sua aplicação no ensino de retas paralelas, XV EPENN - Encontro de Pesquisa Educacional Do Nordeste, São Luis, 2001, p. 590-609.

[5] CHEVALLARD, Yves. El análisis de lãs pácticas docentes em la teoria antropológica de lo didáctico. In: Recherches em Didactique des Mathématiques, Vol. 19, n. 2, p. 221-266, 1999.

[6] CUNHA, S. R. ; PINTO, M. M. F. . O conhecimento esperado sobre limites e continuidade a partir de uma análise das provas unificadas de Cálculo I na UFRJ. Educação Matemática Pesquisa (Online), v. 16, p. 259-278, 2014.

[7] DUVAL, Raymond. Strutucture du raisonnement déductif e apprentissage de la démonstration, In : Educational Studies in Mathematics, 22, 1991, p. 233-261.

[8] FISCHBEIN, Efrain. Intuition in science and mathematics: an educational approach, Netherlands: D. Reidel Public, Mathematics Educational Library, 1987.

[9] LAVE, J. Teaching, as Learning, in Practice. Mind, Culture, and Activity, v.3, n. 3. 1996.

[10] OTERO-GARCIA, S.C. A Transição do Cálculo para a Análise: uma Resenha de Três Trabalhos de Márcia Maria Fusaro Pinto. Bolema, Rio Claro, p. 755 - 761, 01 abr. 2012.

[11] EDGAR, MORIN. Introduction à la pensée complexe. ESF éditeur, coll. communication et, 1990.

[12] MOURIN, Edgar. Introdução ao Pensamento Complexo. Instituto Piaget, Portugal,1995.

[13] MORIN, Edgar. A cabeça bem-feita repensar a reforma reformar o pensamento. Bertrand Brasil, 2003.

[14] MORIN, Edgar. A necessidade de um pensamento complexo. Representação e complexidade. Rio de Janeiro: Garamond, p. 69-77, 2003.

[15] NASSER, L. Uma pesquisa sobre o desempenho de alunos de Cálculo no traçado de gráficos. In: Frota, M.C.R. e Nasser, L (org.). Educação Matemática no Ensino Superior: pesquisas e debates, p. 43-58. SBEM, 2009.

[16] NASSER, Lilian; SOUSA, geneci A.; TORRACA, Marcelo. Transição Do Ensino Médio Para O Superior: Como Minimizar As Dificuldades Em Cálculo? In: V Seminário Internacional de Pesquisa em Educação Matemática, 2012, Petrópolis - RJ. Anais do V Seminário Internacional de Pesquisa em Educação Matemática. Brasília - DF: SBEM, 2012.

[17] PINTO, M. M. F. Entendendo Análise Real. In: Seminário Internacional De Pesquisa Em Educação Matemática. Serra Negra: SBEM, 2000. p.153 - 158.

[18] PINTO, M. M. F. . Re-visitando uma teoria: O desenvolvimento matemático de estudantes em um primeiro curso de analise real. In: Maria Clara Rezende Frota; Lilian Nasser. (Org.). Educação Matemática no Ensino Superior. Ed.Recife: Grafica A Unica Ltda, 2009, v. 1, p. 27-42.

[19] PINTO, M. M. F. . Discutindo a Transição dos Cálculos para a Análise Real. In: Jonas Lachini; João Bosco Laudares. (Org.). A Prática Educativa sob o olhar dos Professores de Cálculo1. ed. Belo Horizonte: Editora Funarc, 2001, v. 1, p. 123-145.

[20] TALL, D.O. Advanced Mathematical Thinking. Dordrecht, Boston, London: Kluwer Academic Publishers. 1991

[21] TALL, D.O. How Humans learn to think mathematically. Exploring the three worlds of mathematics. New York: Cambridge University Press. 2013. 


\section{Capitulo 19}

\section{As Olimpíadas de Matemática ampliando e fortalecendo o processo de ensino-aprendizagem}

\section{Francisco Pereira de Andrade}

Aleksandre Saraiva Dantas

Walter Martins Rodrigues

Resumo: As Olimpíadas de Matemática tentam aproximar a Matemática da realidade dos alunos da escola básica, são competições que surgiram no século XIX, e em dias atuais existem em parâmetros Internacionais, Nacionais, Estaduais e Regionais e em vários níveis de conhecimento desde o mais elementar até o mais avançado, exigindo do aluno todo seu talento em Matemática, muito estudo, criatividade, um raciocínio brilhante e dedicação, ele deve ser extremamente dedicado em resolução de problemas, pois é através dessa prática que se aplica quase toda a teoria. Não só o discente como também os docentes aprimoram-se a cada instante, cada problema é também um novo ensinamento, uma nova experiência adquirida. Tem-se nesse trabalho discussões em relação a algumas indagações, vários comentários dos atores sociais que participam desse cenário olímpico, alguns desabafos, certas instruções, algumas impressões, contudo, visando à busca pela disseminação do conhecimento matemático e a perfeição. Por fim, fala-se de maneira não exaustiva de certos problemas olímpicos, estes até despertam o interesse do aluno, um incentivo, o gosto pela matemática, mostrando algumas estratégias de resolução.

Palavrqas-chave: Olimpíadas de Matemática; Ensino; Aprendizagem; Metodologia de ensino. 


\section{INTRODUÇÃO}

As Olimpíadas de Matemática visa melhorar acima de tudo a qualidade do ensino, da educação matemática (Educação matemática, neste caso, é a capacidade de o aluno saber interpretar, analisar, criar situações problemas e resolver problemas com várias estratégias), visando encontrar aqueles talentosos em cálculos, que tenham um raciocínio ágil e preciso. Uma das características marcantes dessas competições é o uso de questões problemas desafiadoras que exigem do estudante muita capacidade criativa na resolução dos mesmos.

As Olimpíadas Científicas de Matemática no Brasil e em vários países são consideradas momentos privilegiados para a divulgação científica e para a descoberta e incentivo de novos talentos. 0 caráter competitivo estimula a inventividade dos alunos e professores, além de fornecer elementos fundamentais ao Ministério da Educação para avaliar os estudantes brasileiros em relação aos alunos de outros países. 0 Professor do Departamento de Ciências Aplicadas à Educação, da (UFMG) e membro do GAME - Grupo de Avaliação e Medidas Educacionais, José Francisco Soares adota a seguinte hipótese explicativa para os impactos positivos das Olimpíadas Científicas: "Qualquer envolvimento da escola em algo pedagogicamente relevante produz resultados".

Vale salientar que o docente deve buscar um aperfeiçoamento em áreas específicas, em programas de especializações contribuindo assim para qualidade da educação básica. O Mestrado Profissional em Matemática - PROFMAT é um programa desafiador, onde professor que participa cursando todas as disciplinas, certamente enriquecerá sua prática, terá aprimoramento na sua formação e seus alunos só têm a ganhar mais conhecimentos durante suas aulas.

Temos hoje brilhantes matemáticos e cientistas de renome mundial que tiveram origem nas Olimpíadas de Matemática. Entretanto, reconhecemos que, com esta atividade, pode-se fazer muito mais. Com parceria Instituto de Matemática Pura e Aplicada (IMPA) e com a Sociedade Brasileira de Matemática (SBM), foi submetido ao CNPq um projeto que pretende contribuir para a melhoria do ensino de Matemática no Brasil utilizando as Olimpíadas de Matemática como mecanismo propagador. (revista Eureka! número 1-1998 apresentação, Pag. 3).

É fato notável com relação ao programa de mestrado - PROFMAT - que sua coleção, livros, materiais propostos, sites, muitas vezes nos desenvolvimentos dos conteúdos e dos exercícios propostos, há uma conexão com o programa de Olimpíadas de Matemática no Brasil e no mundo, como, por exemplo, a disciplina de "Resoluções de Problemas", obrigatória no mestrado.

As pessoas que fazem parte do estudo são consideradas sujeitos que participam da construção do projeto, são eles que dão sentido à pesquisa. A importância deste tipo de pesquisa é que todos os dados coletados são construtivos, por isso não se deve "evitar o efeito reconstrutivo de toda a análise, mas de fazê--lo criticamente, de modo que possa ser sempre questionado abertamente, refeito e rediscutido" (DEMO, 2001, p. 33). Entre outras consequências metodológicas, isso implica que os dados disponíveis nos questionários contextuais respondidos pelos alunos e professores servirão para ter uma discussão em vários aspectos metodológicos à cerca das Olimpíadas de Matemática.

Apresenta-se algumas tomadas de decisões apoiadas e pressupostas nas leituras de Pádua (1997).

[...] pesquisa é toda atividade voltada para a solução de problemas; como atividade de busca, indagação, investigação, inquirição da realidade, é a atividade que nos permite, no âmbito da ciência, elaborar um conhecimento, ou um conjunto de conhecimentos, que nos auxilie na compreensão desta realidade e nos oriente em nossas ações. (PÁDUA, 1997, p.29).

De acordo com Marconi e Lakatos (2003, p. 155) a pesquisa "é um procedimento formal, com método de pensamento reflexivo, que requer um tratamento científico e se constitui no caminho para conhecer a realidade ou para descobrir verdades parciais." Trata-se aqui, portanto, de explicar os caminhos e os procedimentos metodológicos que serão seguidos na pesquisa, a fim de assegurar a execução dos objetivos propostos, contribuindo para que se consiga fazer a interpretação dos dados mantendo o rigor científico. 


\section{REVISÃO BIBLIOGRÁFICA}

As Olimpíadas Científicas se configuram como qualquer atividade extracurricular que visa atingir objetivos intelectuais, afetivos e sociais. Existem dois tipos de atividades consideradas como Olimpíadas: aquelas que se voltam para o rendimento físico e habilidades esportivas e as que exploram o conhecimento de sala de aula, como o caso das Olimpíadas científicas (ALVES, 2010).

Essas atividades, embora sejam extracurriculares, afetam o cotidiano, a organização escolar e a rotina de sala de aula. Caracterizadas como Olimpíadas científicas, podem acontecer de maneira individual ou coletiva. Quando tem caráter individual, o competidor precisa obter pontuação superior aos demais participantes durante as tarefas exigidas. Já nas atividades coletivas, o grupo deve desenvolver de forma colaborativa o conhecimento para que todos sejam vitoriosos. Existe uma percepção que os ambientes colaborativos apresentam maior aspecto salutar enquanto competição, embora não elimine por completo a ideia que existam perdedores nas atividades. Assim, pode existir uma desmotivação ao estudo por motivo do mau resultado obtido (DOHNE, 2003).

Rezende e Ostermann (2012) afirmam que as Olimpíadas podem acentuar as diferenças sociais e afastar o interesse do aluno no estudo. As autoras ainda afirmam que não se devem usar essas competições como motivação aos alunos nem como política pública de incentivo à educação, mascarando as mazelas do sistema educacional brasileiro. Elas ainda ressaltam que as atividades colaborativas realizadas sem competições e disputas individuais apresentam maiores resultados como um todo.

Com o título "Olimpíadas de Matemática, Altas Habilidades e Resolução de Problemas", Bagatini (2010), em seu trabalho de conclusão de curso para obter o título de Licenciado em Matemática pela UFRGS, realiza uma investigação sobre a OBMEP, identificando que os premiados nessa avaliação são reconhecidos pela sua alta habilidade em Matemática e, por consequência, pela capacidade de resolver problemas. Também foram levantadas as características de pessoas com altas habilidades e intervenções especiais que podem ser feitas com esse público.

Em levantamento com alunos da UFRGS, foi percebido que a matemática do ensino regular não é suficiente para se destacar em uma competição como a OBMEP, embora os conteúdos e raciocínios sejam equiparáveis aos dados até o Ensino Médio. Os estudantes apontaram que faltam abordagens sobre resolução de problemas, exigindo deles raciocínio. 0 autor indica que a utilização de questões de Olimpíadas pode reverter esse quadro de falta de contextualização, trazendo o esperado aprendizado em matemática. Ramalho (2011), durante o III Encontro Regional em Educação Matemática (III EREM), no Rio Grande do Norte, publicou o artigo "E a Educação de Estudantes com Talentos em Matemática?", relata as experiências pessoais do autor na implantação de projetos destinados à educação de estudantes com reconhecido talento em Matemática. $\mathrm{O}$ autor mostra que no Brasil são necessárias estratégias para atender esse público. Apontada como limitação dos NAAHS (Núcleo de Atividades de Altas Habilidades/Superdotação), criado em 2005, com presença apenas em capitais, deixando de atender os alunos talentosos do interior do país. 0 autor, em 2010, colaborou com a criação de um projeto de extensão, vinculado a UFPel, para o atendimento desse público. Houve participação efetiva dos alunos da licenciatura da Universidade, o que contribuiu para a identificação dos alunos com potencial e estender as ações ao maior número de estudantes. Além disso, criou-se um espaço de atuação e investigação para os licenciandos. $\mathrm{O}$ autor acredita no sucesso do projeto.

Em mais um artigo de título "Refletindo Experiências e Práticas de Ensino de Matemática no Programa Novos Talentos da UFPel", Ramalho e Brum (2012) explicitam o projeto "Novos Talentos: Atividades Extracurriculares em Matemática - PNT". As atividades acontecem aos sábados para alunos da rede pública de Pelotas, no Rio Grande do Sul. A participação é gratuita e voluntária para os estudantes. São realizadas atividades extracurriculares, além de oportunas visitas técnicas em setores da própria Universidade ou de outros espaços. Os professores e alunos da licenciatura em Matemática elaboram uma avaliação com conteúdo de ensino fundamental, como um pré-teste. Foi diagnosticado que os alunos não detinham os conhecimentos preconizados pelos PCN (Parâmetros Curriculares Nacionais). Moreno e Fajardo (2013) expõem um levantamento do Movimento Todos pela Educação que apontam atitudes que servem de bom exemplo para o ensino de matemática. Verificar de perto o dever de casa, oferecer aulas de reforço, incentivo dos professores e aproveitar as parcerias com o governo foram as relacionadas no levantamento.

A começar pela OBMEP e seus impactos no desempenho dos alunos e avaliações educacionais, Biondi, Vasconcellos e Menezes-Filho (2009) fizeram uma pesquisa para análise do custo-benefício do programa e foi analisado, estatisticamente, o rendimento de alunos, participantes ou não da OBMEP, da $8^{\text {a }}$ série na Prova Brasil. Fica demonstrado que a Olimpíada traz um efeito positivo e de significância estatística de 
2,14 pontos nas médias de matemática de escolas participantes da Prova Brasil de 2007. Na análise de retorno econômico, foi determinado um resultado positivo, causando impacto direto nas avaliações educacionais e também em ganhos financeiros mais elevados no mercado de trabalho dos participantes.

Segundo (BIONDI e tal. (2009, p.1) "A OBMEP tem efeito positivo e estatisticamente significativo nas notas médias das escolas na Prova Brasil (2007), na oitava série do ensino fundamental. Esse impacto é crescente conforme o maior número de participações das escolas nas edições anuais da OBMEP”

De acordo com Nascimento e Oeiras (2006), competições escolares como as Olimpíadas de Matemática são atividades pedagógicas capazes de provocar desenvolvimento intelectual, autonomia, estímulo ao trabalho individual ou mesmo em equipe, objetivando aperfeiçoar conhecimento de natureza matemática.

\section{METODOLOGIA}

0 trabalho objetiva verificar se as Olimpíadas estimulam o gosto e promovem o incentivo pela matemática entre os estudantes das escolas públicas, que ações poderiam ser acionadas para melhoria da Educação Básica e que contribuições estas dariam para o desenvolvimento social. Assim é de cunho investigativo e colhe informações das Olimpíadas de Matemática OBMEP e OBM em todo alto sertão da Paraíba, através de entrevistas a estudantes e professores, a fim de conhecer um pouco da realidade olímpica das escolas participantes, atacando certos atores sociais como alunos e professores. Naturalmente, é no aluno que se concentram todas as expectativas para obtenção de sucesso de uma Olimpíada de Matemática, mas é imprescindível a atuação do professor numa Olimpíada de Matemática, e consequentemente altera a realidade da escola.

Baseando-se nos objetivos de algumas Olimpíadas de Matemática (OBMEP, OBM, por exemplo) estas trazem o incentivo, desenvolvem o gosto pela matemática, tentam promover e contribuir para a melhoria da educação básica, desenvolveu-se uma pesquisa qualitativa e quantitativa para investigar alunos e professores em algumas escolas estaduais da cidade de Sousa, Estado da Paraíba. Aplicou-se um questionário específico de 8 questões para os alunos com um total de 123 entrevistados, estudantes do Ensino Médio das escolas ENE José de Paiva Gadelha e EEEM e Mestre Júlio Sarmento.

Analisando as 123 respostas coletadas dos alunos, e identificou-se que 17 nunca participaram de uma Olimpíada e os 106 alunos restantes que participaram de Olimpíadas, percebeu-se que na OBMEP 85 participaram dez vezes, 8 participaram em nove edições, 2 participaram em seis ocasiões, 5 participaram em cinco oportunidades, 3 competiram quatro vezes e outros 3 em duas oportunidades. Constatou-se também um número mínimo de alunos que tiveram a oportunidade de frequentar outras competições, apenas 15 já participaram da OBM em alguma de suas edições.

\section{RESULTADOS E DISCUSSÂO}

Analisando as 106 respostas dos estudantes, percebeu-se que estes já participaram de uma Olimpíada, dentre os quais 60 já passaram para segunda fase da OBMEP em alguma oportunidade. Os demais que não passaram para a segunda fase de nenhuma Olimpíada de Matemática dizem não sentirem angustia por não estarem entre classificados.

Ao questionarmos se a participação reflete-se positivamente em outros conteúdos, identificou-se que de certa forma, ao estudar conteúdos mais profundamente, fazer provas mais difíceis, com certeza seu desempenho irá melhorar. Dos resultados obtidos constata-se que dos 106 alunos que já participaram de alguma Olimpíada e dos 60 que passaram para a segunda fase, 58 responderam que a fizeram com o objetivo de aumentar os conhecimentos matemáticos, na oportunidade de desenvolver o raciocínio e o lado criativo, eles afirmam que isso os ajudou diretamente em outras ciências exatas como física e química, enquanto que 2 disseram que não melhoraram em outras disciplinas. E entre os 46 alunos que não passaram para segunda fase de uma Olimpíada, 35 afirmam terem melhorado o desempenho em outras disciplinas, enquanto 11 não perceberam melhoras ainda. Nessa oportunidade, alguns comentaram que após alguns anos estudando pelo banco de questões da OBMEP, evoluíram nas notas de matemática bem como seu raciocínio de interpretação em outras disciplinas ficou mais ágil, 12 não quiseram opinar. 
Dos 60 alunos que passaram para segunda fase, vê-se que 58 afirmam ter melhorado em outras disciplinas, este número representa quase $97 \%$ do total e dos 46 que não passaram, 35 afirmam ter melhorado, isso perfaz 76\%. Diante desses fatos, conclui-se que quem passa para segunda fase, está mais bem preparado, é um aluno mais dedicado e reflete isso em outras áreas. Assim, avançar uma fase de uma Olimpíada de Matemática exige dedicação e esforço. Observou-se que dos 106 alunos participantes de uma Olimpíada, 93 afirmam ter melhorado em outras disciplinas, o que corresponde a aproximadamente $88 \%$ do total, fica evidente, é fato notável que as Olimpíadas de Matemática desenvolvem o raciocínio dos alunos, estimulam e melhoram seu desempenho em outras disciplinas.

Com o intuito de verificar o nível de dificuldade das questões, analisou-se a percepção dos alunos no sentido de indentificar se eles acham conveniente para aquela série que cursa. Observando as respostas dos alunos que já participaram de uma Olimpíada de Matemática - 106 estudantes - constata-se que 72 mencionam o alto nível de dificuldade da prova, conhecimento exigido diferente da realidade das escolas públicas; 20 citam que o conteúdo da prova é incompatível com as diferentes séries, o envolvimento dos professores é precário, problemas de transporte e deslocamento rural-urbano ou ainda fins de semana para fazer a segunda fase da OBMEP que é realizada no sábado no turno da tarde; 14 estudantes listaram, principalmente, que a premiação é insuficiente para a quantidade de alunos, listam ainda professores e escolas sem certificados, questões com enunciados longos, o que dificulta a compreensão. No geral, a maioria dos alunos considera as questões difíceis.

Desta forma, constata-se que os diferentes alunos consideram as provas de Olimpíadas de Matemática difíceis, seja pelo conteúdo oferecido até a data de aplicação das provas da Olimpíada ou ainda não abordado em determinadas séries.

Em relação a motivação nos estudos, a questão indicando se a participação da Olimpíada de Matemática pode estimular novos conhecimentos aos alunos. De acordo com os 106 questionários dos alunos que afirmam ter participado de alguma Olimpíada de Matemática, observa-se que, 24 responderam que a participação não estimula a busca de novos conhecimentos na Matemática; destes, 6 não se sentem motivados, 8 apontam a falta de interesse, 5 ressaltam a dificuldade com o conteúdo de Matemática e outros 5 garantem não gostar de Matemática. Portanto, não se pode apontar a falta de estímulo para buscar novos conhecimentos como a principal dificuldade em obter conhecimento matemático. 0 que também chama atenção é que, dentre os 8 estudantes que apontam a falta de interesse, 3 usam como argumento a falta de estímulos e preparo da escola na competição: "a escola não nos estimula nem a participar da OBMEP”, diz um dos estudantes. Uma dessas declarações permite inferir - e não concluir que um dos motivos do aluno estar desinteressado não parte da opinião pessoal de não gostar de Matemática: a maior parte das manifestações dos alunos nesta questão aponta que a escola não está preparada para fornecer e aplicar provas da OBMEP. Para 82 alunos, a participação numa Olimpíada estimula a buscar novos saberes; destes, 9 se sentem motivados, 40 dizem que a Olimpíada provoca a busca por novos conhecimentos em Matemática, 6 consideram a prova importante e 3 tratam a OBMEP e a OBM importantes.

Na visão do aluno, as Olimpíadas testam os conhecimentos, o raciocínio lógico, sua capacidade de pensar rápido, como se comportar em certas situações adversas, exigindo de cada um, desempenho racional, futuramente, possibilitando cada vez mais a descoberta de um talento em si. Um ponto negativo concentra-se fortemente na questão do alto nível de exigência da prova frente à situação do ensino público na maioria das escolas dessa região.

Em relação aos docentes, importantes fatos e dados que levam a compreender os objetivos da pesquisa em questão, foram ouvidos 12 professores de Matemática do Ensino Fundamental e Médio das Escolas ENE José de Paiva Gadelha e EEEM Mestre Júlio Sarmento. Procurou-se identificar o papel do professor mediando seu grau de instrução, de preparação e de estudos de formação. Para caracterização dessa amostra, analisa-se de forma conjunta a faixa etária e o grau de formação dos professores de acordo com o quadro a seguir, assim, 3 professores tem faixa etária entre 18 e 30 anos (25\%), 3 entre 31 e 40 anos (25\%), 4 tem idades entre 41 e 50 anos (33\%), 2 tem idades entre 51 e 60 anos (17\%) e nenhum professor tem idade maior que 60.

Quanto ao grau de escolaridade, 4 possuem somente curso superior (33\%), 8 possuem especialização (67\%) e nenhum professor possui mestrado ou doutorado. Destaca-se que com relação ao grau de formação, como esperado nas respostas, 67\% possui pós-graduação (especialização), mas esta segunda parte desse quesito gerou certas indagações e alguns desabafos dos professores. 
Por unanimidade todos os professores afirmam que sua escola já participou de uma Olimpíada de Matemática e citam terem participado da OBMEP. Esta questão trata de uma parte importante no que diz respeito ao ambiente olímpico, investiga se existe o estímulo, por parte dos responsáveis, em divulgar a Olimpíada e fazer com que aconteça essa dinâmica.

Um dos interesses da Olimpíada é aprofundar o conhecimento dos professores, acontece mudanças radicais na prática docente, principalmente no que diz respeito à parte conceitual da Matemática e suas aplicações. Infelizmente, esta situação passa despercebida, pelo despreparo teórico do professor e pelo formato dos livros didáticos que, em geral, se limitam a aplicações imediatas e sem expressão científica. Alguns desafios são encontrados já que as Escolas não recebem apoio financeiro para preparação e participação dessas competições, para vencê-los, ela procura fazer reuniões com Professores e Alunos para mostrar a importância destes eventos, além de traçar metodologias e estratégias a serem aplicadas para o desenvolvimento e aprimoramento dos conteúdos olímpicos, planejando aulas em horário oposto e nos finais de semana. Apesar da resistência de alguns Alunos, a maioria se mostra confiante, diminuindo a rejeição ao estudo da Matemática.

O Índice de Desenvolvimento da Educação Básica (IDEB) entre 2005 e 2013 da ENE José de Paiva Gadelha no $9^{\circ}$ do Ensino Fundamental analisando o resultado da meta nacional $(2,7 ; 3,0 ; 3,2 ; 3,6)$ em comparação com a média da Escola $(2,8 ; 3,3 ; 2,7 ; 3,8 ; 3,9)$ ao longo de todo o período, aquela só é mais alto que a média da Escola no ano de 2009 do indicador para o Brasil, contudo o resultado para a Escola Normal demonstra que a mesma conseguiu evoluir em um ritmo mais rápido que o índice do país.

\subsection{SAINDO DA ROTINA: RESOLUÇÃO DE PROBLEMAS.}

Segundo Maria da Silva (2008), não é exagero afirmar que o método de Ensino através de resolução de problemas é um dos mais importantes para aprender matemática com qualidade. 0 professor enquanto mediador da aprendizagem e, principalmente, de matemática olímpica, deve aprimora-se a todo instante, dominar bem os conteúdos e, no âmbito olímpico, conhecer teoria e prática, ter uma vasta experiência em resolução de problemas, principalmente, nas áreas de geometria, combinatória, teoria dos números e álgebra.

"A transferência do aprendizado resultante de uma certa situação para uma situação nova é o ponto crucial do que se poderia chamar aprendizado da matemática e talvez o objetivo maior do seu ensino". (D’AMBRÓSIO, 1986, p. 44).

É importante salientar que para poder ter êxito na resolução de problemas olímpicos, inicialmente deve-se rever vários teoremas, postulados, axiomas. Não intimidar o aluno com matemática, caso contrário, isso pode ferir sua mente tornando indisposto para lhe dar com matemática a vida inteira, o professor tem um papel fundamental nesse processo: o de despertar nele o gosto pela matemática, desenvolver hábitos de lidar com problemas matemáticos, ampliando assim suas habilidades e estratégias, POLYA destaca:

Uma grande descoberta resolve um grande problema, mas há sempre uma pitada de descoberta na resolução de qualquer problema. 0 problema pode ser modesto, mas se ele desafiar a curiosidade e puser em jogo as faculdades inventivas quem o resolver por seus próprios meios experimentará a tensão e gozará o triunfo da descoberta. Experiências tais, numa idade susceptível, poderão gerar o gosto pelo trabalho mental e deixar, por toda a vida, a sua marca na mente e no caráter. (POLYA, 1995, p.v).

Percebe-se que o autor destaca que através da resolução de problemas o aluno aprende, aprofunda e pode criar novas situações de resolução de outros problemas, desenvolve novas estratégias, faz o caminho inverso, rever teoremas e aplica de maneira precisa e sistemática.

Segundo Carneiro (2004), em linhas gerais, os conteúdos de matemática abordados em Olimpíadas são divididos em Teoria dos números, Álgebra, Geometria e Combinatória. 
Os problemas selecionados nesse trabalho possuem um caráter olímpico, prático-aplicativo atendendo também a algumas necessidades dos alunos da Educação Básica, dessa forma, observa-se que a proposta é de cumprir, contemplar os 4 temas acima citados nas competências almejadas para os desafios da resolução de problemas olímpicos.

Os PCN'S contemplam que:

"Duas forças indissociáveis estão sempre a impulsionar o trabalho em Matemática. De um lado, o permanente apelo das aplicações às mais variadas atividades humanas, das simples na vida cotidiana, às mais complexas elaborações de outras ciências. De outro lado, a especulação pura,a busca de respostas a questões geradas no próprio edifício da matemática. A indissociabilidade desses dois aspectos fica evidenciada pelos inúmeros exemplos de belas construções abstratas originadas em problemas aplicados e, por outro lado, de surpreendentes aplicações encontradas para as mais puras especulações, (BRASIL, 2006, p.25)

Quando é mostrado ao discente que a matemática vai muito além do simples e abstrato, que ela não se resume em cálculos secos, o mesmo enxerga a beleza da matemática e começa a intercalar teoria e prática despertando seu interesse. São esses dois lados que fazem a diferença no desenvolvimento cognitivo e fixação da aprendizagem.

\section{CONSIDERAÇÕES FINAIS}

Este trabalho contemplou os vários aspectos do cenário de Olimpíadas de Matemática. A proposta principal desse projeto foi mostrar os impactos de uma Olimpíada no ambiente das escolas estaduais de Sousa.

No Brasil, tem-se a OBMEP e OBM - duas grandes competições- cujos objetivos são claros preocupando-se com a melhoria da qualidade da educação, despertando o interesse, a criatividade e a motivação dos alunos.

Desta forma, de acordo com os objetivos desse trabalho e diante das entrevistas realizadas com Alunos e Professores das Escolas ENE José de Paiva Gadelha e EEEM Mestre Júlio Sarmento, dos resultados colhidos e das observações feitas, percebe-se que é sempre positivo o impacto trazido por uma Olimpíada, mostra assim uma significativa melhoria da qualidade no ensino da matemática, isso foi constatado em algumas discussões e resultados analisados, nas situações já vivenciadas por alunos e professores e nos aspectos do resultado da Prova Brasil, O IDEB da Escola Normal está maior que a meta estipulada em âmbito nacional, diante desses fatos, uma Olimpíada propicia aos alunos e professores, que se envolvam nessas competições, o desenvolvimento de um espírito de trabalho em equipe, aprofundamento dos seus conhecimentos e disseminação do conhecimento.

Assim o docente e discente que participam de uma Olimpíada, terão oportunidade de estarem em contato com novas ideias da matemática, estimulando seu raciocínio e criatividade. E com o envolvimento daqueles dois atores sociais, haverá certamente maiores e melhores aproveitamentos de ensino aprendizagem, culminando com o desenvolvimento social.

\section{REFERÊNCIAS}

[1] __ Brasil, Ministério da Educação (MEC), Secretaria de Educação Média e Tecnológica (Semtec). PCN + Ensino médio: orientações educacionais complementares aos Parâmetros Curriculares Nacionais - Ciências da Natureza, Matemática e suas Tecnologias. Brasília: MEC/Semtec, 2002.

[2] ALVES, W. J. S. O impacto das Olimpíadas de Matemática em Alunos da Escola Pública. 2010. 92 f. Dissertação (Mestrado Profissional em Ensino de Matemática) -Pontifícia Universidade Católica de São Paulo, São Paulo, 2010.

[3] Avaliação do impacto da Olimpíada Brasileira de Matemática nas Escolas Públicas (OBMEP), Série Documentos Técnicos Julho 2011 - № 11. 
[4] BAGATINI, A. Olimpíadas de Matemática, Altas Habilidades e Resolução de Problemas. 2010. 82 f. Graduação (Licenciatura em Matemática) - Universidade Federal do Rio Grande do Sul, Porto Alegre, 2010.

[5] BIONDI, R. L.; Vasconcellos, L.; Menezes-Filho, N. A. Avaliando o impacto da Olimpíada Brasileira de Matemática das Escolas Públicas (OBMEP) no desempenho de matemática nas avaliações educacionais. In: 31ำ Encontro da Sociedade Brasileira de Econometria, 2009, Foz do Iguaçu. Anais... Encontro de Econometria - SBE, 2009.

[6] BRASIL. Ministério da Educação (MEC), Secretaria de Educação Básica (SEB), Departamento de Políticas de Ensino Médio. Orientações Curriculares do Ensino Médio: Ciências da natureza, matemática e suas tecnologias. Brasília: MEC/SEB, 2006..

[7] CARNEIRO, E. Olimpíadas de Matemática - Uma porta para o futuro: Dicas para montar um projeto e 50 problemas de treinamento para iniciantes. II Bienal da SBM. Salvador, Bahia, 2004.

[8] D’AMBRÓSIO, Ubiratan. Da realidade à ação: reflexões sobre a educação, 1986, p. 44.

[9] DEMO, Pedro. Pesquisa e informação qualitativa: Aportes metodológicos. Campinas, SP: Papirus, 2001. Disponivel EM: http://www.olimpiadascientificas.com.

[10] DOHNE, V. O valor educacional dos Jogos. São Paulo: Informal Editora, 2003.

[11] LAKATOS, Eva Maria e MARCONI, Marina de Andrade. Fundamentos da Metodologia científica. 5a ed. São Paulo: Editora Atlas S.A., 2003, Pag. 155.

[12] MORENO, A. C.; Fajardo, V. Dez escolas públicas mostram como obter bons resultados em Matemática. G1. 05 de Dezembro de 2013. Disponível em: http://www.g1.globo.com/educacao/noticia/2013/12/dez-escolaspublicas-mostram-como obter-bons-resultados-em-matematica.html>. Acesso em: 01 fev. 2014.

[13] NASCIMENTO. Márcio Góes; OEIRAS. Janne Y. Y. Olímpico: Um Ambiente Virtual para Competições Escolares Via Internet, Belém, PA: UFPA, 2006.

[14] Olimpíada Brasileira de Matemática. Disponível em: < http://www.obm.org.br>.Acesso em: out.2014 Olimpíadas Brasileira de Matemática das Escolas Públicas. Disponível em:< http://www.obmep.org.br/estudos.html >. Acesso em: out. 2014.

[15] PÁDUA, E. M. M D. Metodologia da Pesquisa: Abordagem Teórica-Prática. 2ª ed. Papirus, Campinas, SP, 1997.p. 29.

[16] POLYA, George. A arte de resolver problemas. Rio de Janeiro: Interciência, 1995.

[17] RAMALHO, J. V. A. E a Educação de Estudantes com Talento em Matemática? In: III Encontro Regional em Educação Matemática, 2011, Natal. Anais... Encontro da SBEM- RN, 2011.

[18] RAmalHO, J. V. A.; Brum, R. S. Refletindo Experiências e Práticas de Ensino de Matemática no Programa Novos Talentos da UFPel. In: 1o Encontro Nacional PIBID- Matemática, 2012, Santa Maria. Anais..., 2012.

[19] REZENDE, F; Ostermann, F. Olimpíada de Ciências: Uma prática em questão. Ciência \& Educação, Bauru, v. 18, n.1, p. 245-256, 2012.

[20] SILVA, Maria José de Castro. As relações entre a aprendizagem da matemática e a resolução de problemas. Anuário da Produção Acadêmica Docente. Vol. II. n. 3. Unianhanguera. 2008. P. 223-232. 


\section{Capítulo 20}

O ensino-aprendizagem de porcentagem na EJA com o uso de estratégias metacognitivas

\section{Mariana Figueira Secafim \\ Marta Maria Pontin Darsie}

Resumo: Esse trabalho apresenta o recorte de uma pesquisa de mestrado realizada pelo Instituto de Educação da Universidade Federal de Mato Grosso (IE/UFMT). Essa investigação teve como proposta apresentar as possíveis contribuições das estratégias metacognitivas no ensino-aprendizagem de porcentagem com estudantes da Educação de Jovens e Adultos (EJA) a partir de resolução de problemas. Procurou-se identificar a potencialidade da metacognição na aprendizagem dos estudantes, verificando os conhecimentos prévios e as heurísticas pessoas de cada um na resolução dos problemas propostos. A pesquisa é de cunho qualitativo sendo que os dados produzidos são analisados e interpretados por meio da pesquisa-ação. Os dados foram mais bem observados a partir da aplicação de pré-teste e pós-teste, além de um questionário de caracterização. Definimos o referencial teórico evidenciando a metacognição e as estratégias metacognitivas, e também as especificidades dos estudantes da modalidade EJA. Para finalizar, verificamos a importância do uso de estratégias metacognitivas no ensino de matemática.

Palavras-chave: EJA; Estratégias metacognitivas; Resolução de problemas; Porcentagem. 


\section{INTRODUÇÃO}

Neste trabalho, apresentamos um breve recorte onde o problema central da pesquisa é a possível potencialidade das estratégias metacognitivas para com o ensino-aprendizagem de porcentagem em estudantes da EJA. Questionamentos do tipo: "como se dá os processos cognitivos e metacognitivos desses estudantes?", fizeram-se presentes durante a intervenção.

É necessário destacar as características de ensino-aprendizagem na modalidade EJA, analisando as dificuldades encontradas pelos estudantes. Nesse sentido, aproximamos o conteúdo ensinado ao contexto social deles, priorizando suas experiências e conhecimentos prévios, que foram obtidos a partir do questionário de caracterização.

Ao utilizar estratégias metacognitivas mostramos aos estudantes que eles devem ter uma postura ativa em sala de aula, sendo sujeitos ativos no seu próprio processo de aprendizagem, direcionando-os a descobrirem os caminhos que estes utilizaram para a resolução de determinado problema.

No entanto, visamos apresentar um recorte do percurso e do desenvolvimento do estudante MAR durante a ação interventiva da pesquisa, mostrando, com base nos dados produzidos, a possível evolução do mesmo. Para esse trabalho será considerada as informações do questionário de caracterização, do préteste e do pós-teste do estudante.

\section{FUNDAMENTAÇÃO TEÓRICA}

Na educação entendemos os estudantes como foco principal no processo de ensino-aprendizagem e considerando que as turmas da EJA são formadas por um grupo heterogêneo de alunos, cabe ao docente fornecer condições adequadas para que todos aprendam. Sendo assim, tem-se a necessidade de enfatizar no processo de ensino-aprendizagem os conhecimentos prévios destes estudantes, reconhecendo-os como construtores da própria aprendizagem.

Ribeiro (2007, p.64) afirma que "o ensino de Matemática que se realiza no contexto da EJA deve se enquadrar na tendência de um ensino preocupado com as transformações sociais, vendo na Matemática um instrumento que nos ajuda a explicar, a compreender, a analisar nossa prática social, e nos ajuda a propor alterações para essa prática".

No que tange ao ensino de jovens e adultos não se pode falar em ensino-aprendizagem sem considerar os conhecimentos prévios e as experiências cotidianas dos estudantes, principalmente no que se refere à Educação Matemática. No que diz respeito aos conhecimentos prévios a Proposta Curricular da EJA afirma que

O ponto de partida para a aquisição dos conteúdos matemáticos deve ser os conhecimentos prévios dos educandos. Na educação de jovens e adultos, mais do que em outras modalidades de ensino, esses conhecimentos costumam ser bastante diversificados e muitas vezes são encarados, equivocadamente, como obstáculos à aprendizagem. Ao planejar a intervenção didática, o professor deve estar consciente dessa diversidade e procurar transformá-la em elemento de estímulo, explicação, análise e compreensão (BRASIL, 2001, p. 102).

Assim, a Educação Matemática preocupa-se com a evolução dos estudantes, objetivando inseri-los no desenvolvimento socio educacional. Os estudantes da EJA, alguns com pouco e outros com nenhum conhecimento escolar, possuem princípios matemáticos adquiridos informalmente ou intuitivamente, como os processos de contagem e cálculo, por exemplo. De acordo com Nogueira (2010, p. 35) "o processo de ensino-aprendizagem deve centrar-se na análise e na interpretação de situações, na busca de estratégias, na discussão de diferentes pontos de vista e de diferentes métodos". Nesse sentido vimos que as estratégias metacognitivas centra-se na análise e interpretação de situações. 
O uso de estratégias metacognitivas aplicadas no contexto da EJA é indispensável para o desenvolvimento da consciência da aprendizagem dos estudantes, já que a partir do momento em que o aprendiz reconhece como se dá o seu processo de aprendizagem, o mesmo toma consciência de como se aprende. John Hurley Flavell, no início da década de 1970, nos Estados Unidos, definiu o conceito de metacognição e metacompreensão da seguinte maneira:

A metacognição está relacionada ao conhecimento que se tem dos próprios processos cognitivos, de seus produtos e de tudo que eles tocam, por exemplo, as propriedades pertinentes à aprendizagem da informação e dos dados [...] $\mathrm{A}$ metacognição relaciona-se a outras coisas, à avaliação ativa, à regulação e à organização desses processos em função dos objetos cognitivos ou dos dados sobre os quais se aplicam, habitualmente para servir a uma meta ou a um objeto concreto. (FLAVELL, 1976, p.232)

Para Baird (1991, p.164) metacognição é:

0 conhecimento do indivíduo sobre a natureza de sua aprendizagem e seu poder e dificuldades particulares, consciência da natureza e do processo das tarefas em andamento (o que está fazendo e como se está fazendo); controle sobre a aprendizagem por meio de tomadas de decisão fundamentadas e com metas definidas.

Sendo assim, a metacognição compreende o conhecimento, a consciência e o controlo que o estudante possui de seu próprio processo de aprendizagem. Ao detalhar as categorias como conhecimento, consciência e controle, Baird (1991) nos possibilita interpretar que o conhecimento corresponde a consciência que o indivíduo tem sobre sua cognição. Consciência é a capacidade de refletir em relação ao conhecimento e acerca de como se dá a prática desse conhecimento. Por fim, o controle tem relação com a auto regulação ou acompanhamento que o indivíduo faz de suas habilidades cognitivas (OLIVEIRA, 2002).

Por isso compreendemos que a metacognição é um instrumento de ensino-aprendizagem, que desperta o interesse do estudante em analisar e refletir a maneira que executa uma dada situação que lhe é proposta.

\subsection{ASPECTOS METODOLÓGICOS}

Para o desenvolvimento da pesquisa utilizamos a abordagem qualitativa com análise descritiva e interpretativa, por caracterizar grande flexibilidade, permitindo amplo e detalhado conhecimento do objeto.

A análise é descritiva e interpretativa, pois objetiva analisar, por meio da interpretação dos dados, se o uso de estratégias metacognitivas aplicada ao ensino de porcentagem na EJA potencializa a aprendizagem desses estudantes, tendo como base o aporte teórico.

0 método utilizado na realização da pesquisa de abordagem qualitativa foi a pesquisa-ação, pois o pesquisador intervém no contexto da investigação, permitindo maior compreensão dos fenômenos. Thiollent (2011, p.20) diz que a pesquisa-ação "é um tipo de pesquisa social com base empírica que é concebida e realizada em estreita associação com uma ação ou com a resolução de um problema coletivo e na qual os pesquisadores e os participantes representativos da situação ou do problema estão envolvidos de modo cooperativo ou participativo".

Acreditamos que tal método nos possibilitou uma percepção mais abrangente no processo de investigação, permitindo discussões e reflexões acerca da metacognição no ensino-aprendizagem de porcentagem.

0 contexto da pesquisa foi uma escola pertencente à rede pública da Secretaria de Educação do Estado de Mato Grosso - SEDUC/MT, localizada no interior do estado. Os participantes foram estudantes do 20 ano do Ensino Médio da EJA, devido a matriz curricular ofertar o conteúdo de matemática financeira, que envolve porcentagem. Porém, nesse trabalho trazemos o desenvolvimento de apenas 1 (um) dos 6 (seis) estudantes participantes do processo interventivo, devido ser um recorte da pesquisa.

Anteriormente as pesquisadoras não possuíam contato direto com os participantes da pesquisa, sendo assim não houve indução nos resultados desta. 
As categorias para a análise dos dados, com o intuito de compreender os processos metacognitivos foi realizada com base nas categorias da metacognição, as quais são: conhecimento, consciência e controle.

\subsection{DESCRIÇÃO E ANÁLISE DOS DADOS}

Para compreender a contribuição das estratégias metacognitivas no ensino-aprendizagem de resolução de problemas de porcentagem na EJA, foi realizada uma ação interventiva, juntamente com a aplicação de um pré-teste e um pós-teste. Algumas informações e discussões sobre o desenvolvimento do estudante MAR será apresenta nesse trabalho.

O estudante MAR tem 18 anos, é lavrador e nunca parou de estudar. Ao ser questionado se tinha alguma dificuldade em aprender matemática, disse que sim sem especificar quais seriam os motivos. MAR afirmou que não gosta de estudar matemática.

No primeiro encontro, que aconteceu no dia 05/04/2018 e teve duração de 2 (duas) horas/aula, foi realizado uma conversa aberta com os estudantes com o propósito de estimular a verbalização (Beyer, 1985) dos mesmos, a fim de socializarmos situações que envolvessem porcentagem no cotidiano.

$\mathrm{Na}$ sequência foi aplicado um questionário com a finalidade de identificar os conhecimentos dos estudantes relacionados a porcentagem e se os mesmos utilizam esse conceito em seu cotidiano.

O estudante apresentou respostas bastante sucintas em seu questionário. Sobre o que entendia por porcentagem disse ser "todos por 100\%", referindo-se a todos os números. Afirmou utilizar porcentagem em sua profissão na fabricação de rações, com o propósito de saber a porcentagem de cada ingrediente a ser adicionado. Declarou ainda resolver os problemas mentalmente e diz não ter dificuldades para resolver problemas que envolvam o conteúdo de porcentagem.

Apresentaremos abaixo as respostas apresentadas pelo estudante no pré-teste, que objetivou verificar os conhecimentos prévios sobre porcentagem.

Quadro 1 - Respostas apresentada por MAR no pré-teste

$$
\text { Problema } 1
$$

Em um depósito de um supermercado possui 10 fardos de arroz, ao comprar um fardo João comprou quantos por cento do total de fardos do supermercado? Explique como você chegou ao resultado.

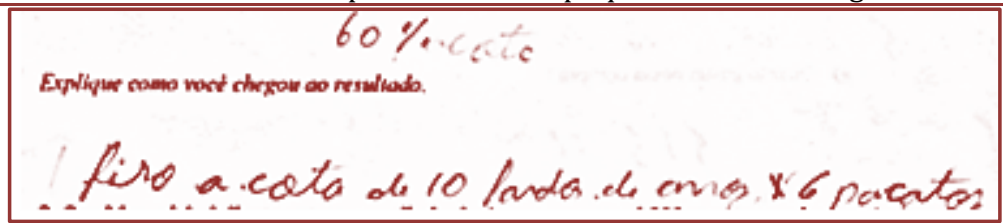

\section{Problema 2}

Seu Manoel é vigilante noturno e a distância do seu percurso é 800 metros, sendo que ele faz a rota 10 vezes por noite. Porém em determinada noite Seu Manoel atrasou-se e só pode completar 8 desses percursos. Quantos por cento a menos ele percorreu nessa noite? Como você chegou a esse resultado?

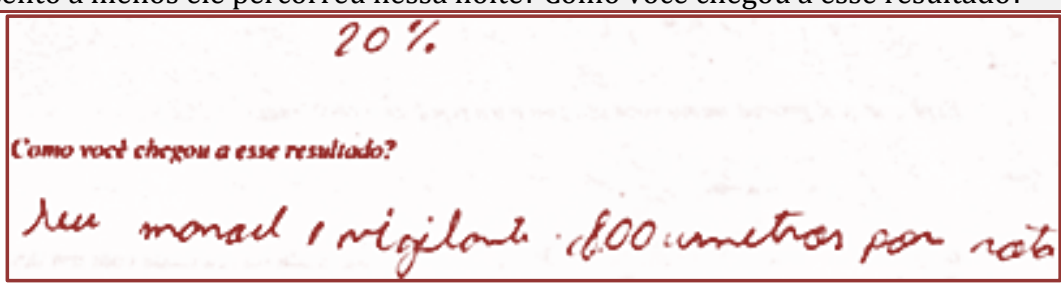

Problema 3

Uma atendente da loja Maria Bonita vende 30 peças de roupas por dia, dessas $70 \%$ é regata. Quantas regatas são vendidas por dia? Como você resolveu o problema?

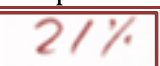


(continuação)

Quadro 1 - Respostas apresentada por MAR no pré-teste

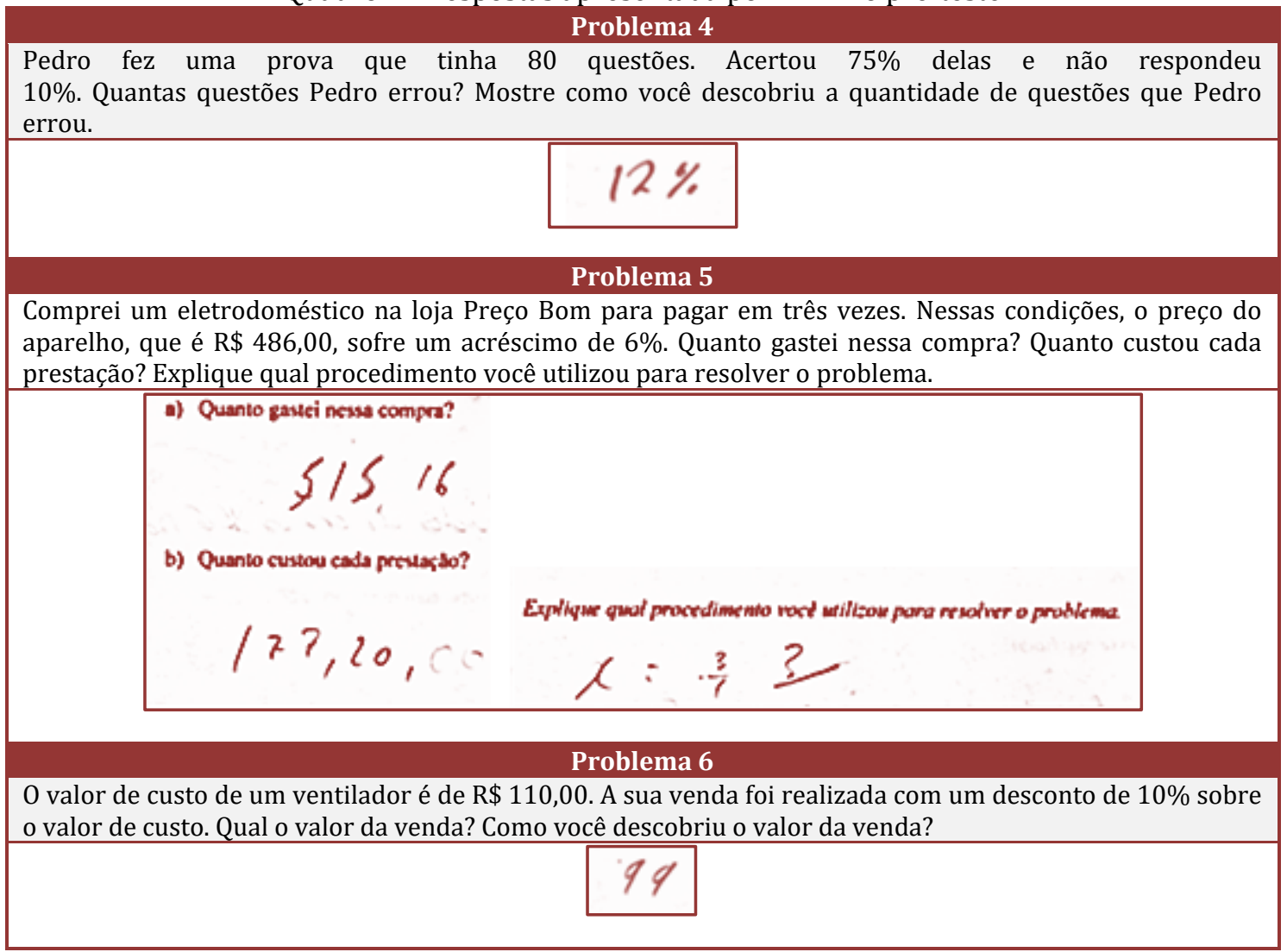

Fonte: Elaborado pela autora

O estudante resolveu todos os problemas do pré-teste diretamente, o que pode ter ocasionado alguns erros durante o processo. Porém o erro é parte essencial no aprendizado, pois proporciona ao estudante a oportunidade de refletir sobre as etapas de resolução.

No primeiro problema, o estudante afirma que ao comprar 1 (um) fardo de arroz João comprou $60 \%$ do total do supermercado, pois ele associa aos 6 (seis) pacotes de arroz que há em um fardo, e como são 10 (dez) fardos ele multiplica 6 (seis) por 10 (dez).

No segundo e no terceiro problema, MAR sinalizou corretamente a resposta, porém não explica como chegou aos resultados corretos, e ao ser questionado afirma ter feito mentalmente. Na tentativa de estimular a verbalização, foi indagado novamente sobre a resolução e respondeu timidamente: "resolvi na cabeça, é difícil falar como".

No quarto problema, MAR também exibiu apenas um resultado, porém ao invés de indicar 12 questões erradas por Pedro, o estudante apresentou 12\%, o que nos leva a compreender que o mesmo não entende todos os significados e símbolos matemáticos.

Para isso, Fonseca (2007) declara a importância de compreender os conceitos e os procedimentos para que o conhecimento matemático seja ampliado.

No quinto problema, o estudante também apresenta apenas os resultados. No entanto na alternativa (b), indica um resultado incorreto. Na descrição do procedimento de resolução podemos perceber uma tentativa de divisão por três, já que são as condições de pagamento do eletrodoméstico, ou seja, em três prestações. Nessa ocasião, é possível perceber que o educando apresenta um conhecimento sobre a aprendizagem e o conteúdo básico da matemática. 
No último problema, MAR outra vez sinalizou somente a resposta correta, sem indicar o processo de resolução. 0 que nos leva a refletir sobre um possível ensino pautado no tradicionalismo.

Com base no pré-teste, apresentado acima, resolvido por MAR foi possível verificar que o estudante possui conhecimentos cotidianos da matemática e que este resolve os problemas mentalmente sem apresentar dificuldades.

A aula 2 aconteceu no dia 12/04/2018, com duração de 4 (quatro) horas/aula. Foi proposto inicialmente uma discussão sobre FGTS e INSS, já que o público alvo da pesquisa eram estudantes jovens e adultos que fazem parte de uma sociedade em consumo, que lida diariamente com tais fatores. Na sequência foi realizado o desenvolvimento de 4 (quatro) problemas.

MAR resolveu todos os problemas utilizando regra de três. No primeiro, como o conceito de FGTS não faz parte da realidade do estudante ele não estava compreendendo por que era descontado esse valor no salário de alguns trabalhadores e após explicar mais detalhadamente o assunto, o estudante compreendeu do que se tratava e então conseguiu resolver o problema proposto. Ao entender o que o problema estava solicitando apresentou consciência de seu processo de aprendizagem.

No terceiro problema o estudante constatou que a quantidade de sacos de cimento vendidos era equivalente a 500. 0 estudante disse: "Já trabalhei muito com cimento na roça". Essa fala nos chamou a atenção, pois ele falou com muita propriedade sobre conhecer tal material, relacionando esse fato a uma melhor compreensão do problema, diferentemente do que aconteceu com o problema que abordava FGTS.

As estratégias metacognitivas utilizadas nessa aula foram as seguintes: definir a compreensão do que está lendo ou executando (Carrasco, 2000); perguntar não apenas pelo resultado, mas também pelo procedimento (Koutselini, 1991); estimular a verbalização dos alunos em relação a suas dificuldades (Beyer, 1985); estimular via modelo (Antonijevic e Chadwick, 1982); referendar o êxito nas atividades (Antonijevic e Chadwick, 1982) e; ensinar estratégias para superar as dificuldades (Koutselini, 1991).

Na aula 3 ocorrida no dia 26/04/2018, com duração de 4 (quatro) horas/aula, os estudantes resolveram 3 (três) problemas em duplas, além de terem produzido o seu próprio problema sobre porcentagem. Trabalhamos com as seguintes estratégias: referendar o êxito nas atividades (Antonijevic e Chadwick, 1982); estimular a verbalização dos alunos em relação a suas dificuldades (Beyer, 1985) e; evidenciar quais elementos são críticos em relação à busca de informação.

O estudante MAR não apresentou dificuldades na resolução dos 3 (três) problemas solicitados. Produziu e solucionou o problema a seguir:

Imagem 1 - Problema produzido pelo estudante MAR

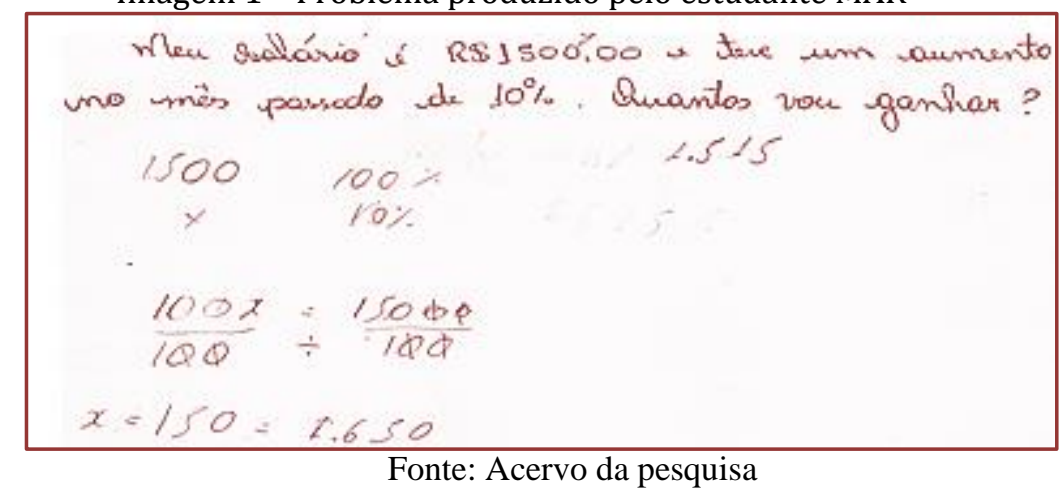

Ao conseguir formular um problema o estudante demonstrou uma tomada de consciência no que tange ao seu aprendizado, no qual incentiva-o a ser criativo e autônomo em seu próprio processo cognitivo, transformando o quadro de exclusão em que a EJA pertence. 
Nessa aula foi possível perceber que MAR evoluiu quanto ao processo metacognitivo. Conforme González (1995, p.53)

Durante as fases de resoluções de problemas, são ativados dois tipos de processos mentais: os processos cognitivos, que tem a ver com a codificação, retenção, organização, processamento e recuperação da informação; e os metacognitivos que são processos que dizem respeito à tomada de consciência, o regulamento que cada pessoa exerce, o controle sobre seus próprios processos cognitivos.

Nesse sentido a tomada de consciência está totalmente relacionada as estratégias metacognitivas, o estudante não deve apenas operacionalizar o algoritmo corretamente e sim compreender o que de fato se trata a resolução de cada problema.

Na última aula interventiva, que se passou no dia 02/05/2018, com duração de 4 (quatro) horas/aula, na última lista de problemas foram aplicadas as seguintes estratégias metacognitivas: compreender as próprias capacidades e como retribuir suas deficiências (Carrasco, 2000); selecionar uma estratégia adequada para solucionar determinados problemas (Carrasco, 2000); referendar o êxito nas atividades (Antonijevic e Chadwick, 1982); estimular a verbalização dos alunos em relação a suas dificuldades (Beyer, 1985); transferir os princípios ou estratégias aprendidas de uma circunstância para outra (Carrasco, 2000) e; estimulá-los a pensar em voz alta (Koutselini, 1991).

Em seguida foi aplicado o pós-teste que tinha o propósito de verificar se houve ou não avanço no uso das estratégias metacognitivas na resolução de problemas.

\section{Quadro 2 - Respostas apresentadas por MAR no pós-teste}

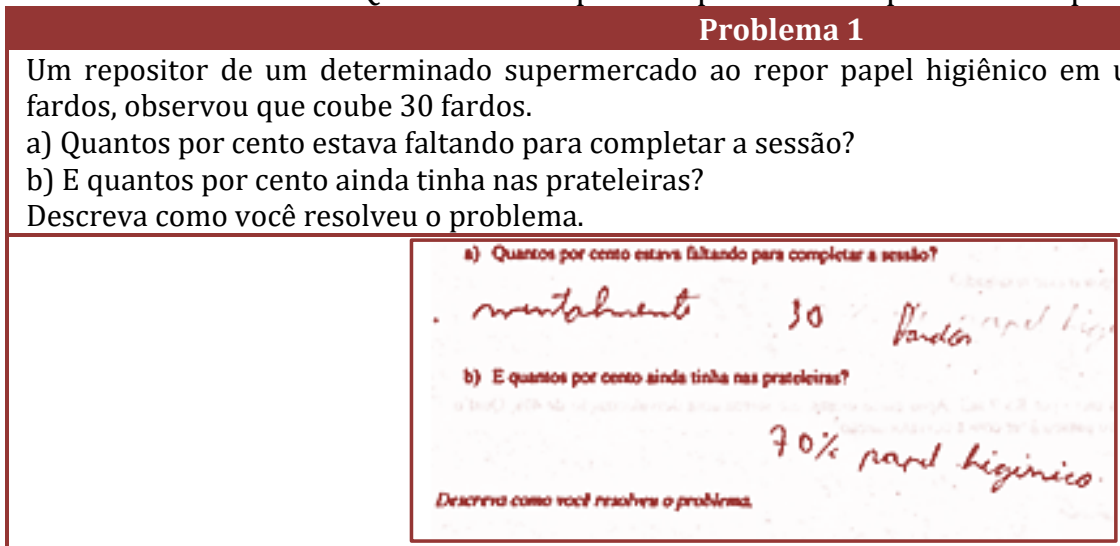

\section{Problema 2}

Para fazer um piso foram utilizadas 50 pás de cimento e 200 pás de areia, em relação a quantidade de pás, qual a porcentagem utilizada em cimentos?

Explique como chegou a esse resultado.

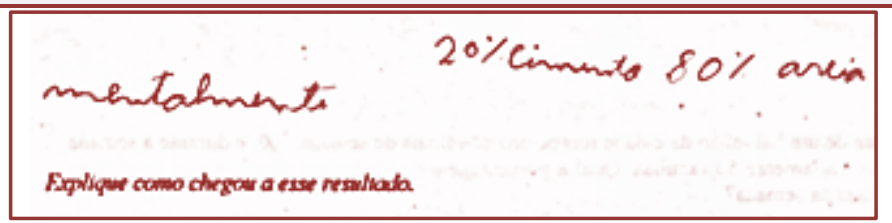

\section{Problema 3}

Para soldar uma porta, Seu Arlindo utiliza 8 eletrodos e para soldar uma janela utiliza 25\% desse valor. Quantos eletrodos ele utiliza para soldar a janela?

Explique como você encontrou a quantidade de eletrodos utilizados para soldar a janela.

$$
\text { mentolnent } 2 \text { eletraclas. }
$$


(continuação)

Quadro 2 - Respostas apresentadas por MAR no pós-teste

\begin{tabular}{l} 
Na fazenda de São José, durante uma seca, morreram 30 bois de uma boiada \\
de 600 cabeças. Qual foi o percentual dos bois que sobreviveram? Como você chegou a esse resultado? \\
\hline mentohnent
\end{tabular}

Problema 5

Comprei um carro por R \$ 9 mil. Após cinco meses, ele sofreu uma desvalorização de 4\%. Qual o valor que o carro passou a ter com a desvalorização?

Explique qual procedimento você utilizou para resolver o problema.

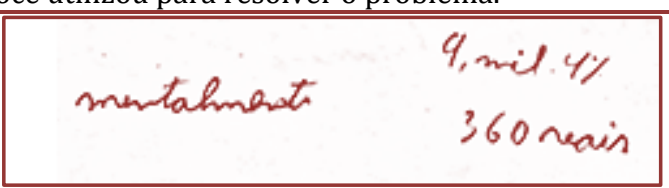

\section{Problema 6}

Uma atendente de um balneário da cidade recepciona nos finais de semana 200, e durante a semana recepciona aproximadamente 50 famílias. Qual a porcentagem de acréscimo dos finais de semana se comparado aos dias da semana?

Explique, com suas palavras, como resolveu o problema em questão.

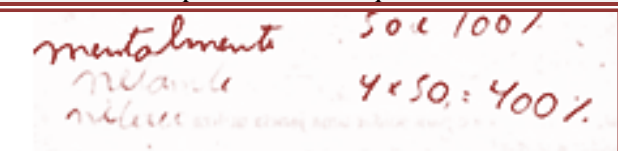

Fonte: Elaborado pela autora

O estudante MAR apresentou corretamente o resultado das alternativas do primeiro problema, porém não apresentou as etapas da resolução e quando questionado proferiu: "Resolvi mentalmente. Acho mais fácil.", isso nos remete aos problemas 2 (dois) e 3 (três) do pré-teste, onde o estudante afirmou possuir facilidade em resolver mentalmente. 0 mesmo ocorreu com o que se refere ao segundo problema, apresentando corretamente o resultado sem expor o processo de resolução.

No terceiro e quarto problema, o estudante novamente apresentou somente o resultado, porém, no problema quatro, MAR sinalizou a resposta incorretamente, o que nos leva a concluir que o estudante não compreendeu o enunciado da questão. Com base nisso, ao ser questionado sobre seu processo mental o estudante declarou: "Acho mais fácil de cabeça professora. Essas contas me confundem".

No quinto problema, o estudante também sinalizou somente o resultado. Entretanto apresentou o valor referente a desvalorização do carro e não concluiu calculando o valor final do carro após o desconto da desvalorização.

No sexto e último problema, o estudante apresentou corretamente a relação de 50 famílias relacionandoas a $100 \%$ e calculou a porcentagem equivalente às 200 famílias dos fins de semana, obtendo um resultado de $400 \%$. Entretanto, o estudante não descontou os $100 \%$ que faziam referência as famílias que frequentavam o balneário durante a semana, sendo assim, não concluiu que o resultado era equivalente a $300 \%$ de aumento.

Com base na resolução dos problemas do pós-teste de MAR, foi possível perceber um avanço considerável em relação ao conteúdo de porcentagem. Sendo assim, o uso de estratégias metacognitivas contribuiu efetivamente para a aprendizagem desse estudante. 


\section{CONSIDERAÇÕES FINAIS}

MAR apresentou uma melhora no que diz respeito a clareza sobre as estratégias utilizadas em cada problema. No começo estava receoso quanto às aulas interventivas e pouco se socializava. Porém no desenrolar dos encontros, o estudante apresentou mais confiança, o que fez com que participasse mais efetivamente. Entretanto, inicialmente MAR demonstrava um conhecimento sobre sua natureza de aprendizagem e durante o processo isso se intensificou. 0 estudante possui muita facilidade em resolver os problemas mentalmente e pouco despertou interesse em aprender outros caminhos, pois ele sempre afirmava que era "muito difícil".

Para mais, MAR não registrava as estratégias adotadas na resolução dos problemas, e isso perdurou por todas as aulas. Sendo assim, no que tange à consciência metacognitiva, o estudante se destacou na compreensão dos problemas, mesmo não descrevendo as etapas.

Apesar de indicar apenas o resultado, apresentou controle de sua aprendizagem, pois conseguiu verbalizar seus processos de resolução, que muitas vezes seguem caminhos distintos dos demais estudantes.

0 estudante correspondeu às intervenções realizadas com as estratégias metacognitivas, pois conseguiu operacionalizar corretamente o algoritmo de resolução de porcentagem, implicando na aprendizagem matemática. Participaram efetivamente do processo de aprendizagem, identificando a melhor maneira de resolver um determinado problema, o que resultou em uma autonomia intelectual, essa autonomia o levou a compreensão dos problemas.

Sendo assim, podemos afirmar que conseguimos atingir os objetivos traçados inicialmente, pois com os questionários identificamos as experiências e conhecimentos prévios relacionados à porcentagem e durante o processo de resolução dos problemas vimos que o educando utilizou heurísticas gerais. Também identificamos os processos cognitivos e metacognitivos durante a resolução dos problemas, especialmente quando o educando verbalizava os caminhos percorridos durante a resolução.

Em suma, podemos concluir que o uso de estratégias metacognitivas na resolução de problemas proporcionou uma grande contribuição para o ensino-aprendizagem de porcentagem do estudante da EJA, além de desenvolver a tomada de consciência e reflexão sobre sua própria aprendizagem frente a um problema matemático.

Por fim, assim como Araújo (2009) e Leite (2011), consideramos que a resolução de problemas de porcentagem com o uso de estratégias metacognitivas contribui significativamente para a aprendizagem matemática de estudantes da EJA, além de possibilitar aos educandos o conhecimento sobre o mundo e seus próprios processos de aprendizagem.

\section{AGRADECIMENTOS}

À Coordenação de Aperfeiçoamento de Pessoal de Nível Superior (CAPES) que contribuiu para o financiamento do trabalho. A todos os participantes envolvidos direta ou indiretamente à pesquisa.

\section{REFERÊNCIAS}

[1] ANTONIJEVIC, N.; CHADWICK, C. Estratégias Cognitivas y Metacognición. Revista de Tecnologia Educativa. vol. 7, n.4. 1982.

[2] ARAÚJO, L. F. Rompendo o contrato didático: a utilização de estratégias metacognitivas na resolução de problemas algébricos. Tese de doutorado. Universidade Federal de Pernambuco - UFPE. Recife, 2009.

[3] BAIRD, I. R.; FENSHAM, P. J; GUSTONE, R. F.; WHITE, R. T. The importance of reflexion in improving science teaching and learning. Journal of Research in Science Teaching. n. 28, v. 2, p. 163-182. 1991.

[4] BRASIL. Ministério da Educação e Cultura. Proposta Curricular para a Educação de Jovens e Adultos: primeiro segmento do ensino fundamental/ coordenação e texto final (de) Vera Maria Masagão Ribeiro. São Paulo: Ação Educativa; Brasília, 2001.

[5] BEYER, B. K. Critical thinking: What is it? Social Education, v. 49. 1985.

[6] FLAVELL, J. H. Metacognitive aspectos of problem solving. In: Resnick, L. B. (Org). The nature of intelligence. New York: Hillsadale Erlbaum. 1976. 
[7] FONSECA, M. C. F. R. Educação Matemática de Jovens e Adultos: especificidades, desafios e contribuições. $3^{\circ}$ ed. Belo Horizonte: Autêntica, 2007.

[8] GONZÁLEZ, F. El corazón de la matemática. Série Temas de educación matemática. 2 ed., jan., Barcelona, 1995.

[9] KOUTSELINI, M. Child development and school reality. Nicosia: Pedagogical. Institute of Cyprus, 1991.

[10] LEITE, E. A. P. Estratégias metacognitivas na resolução de problemas matemáticos: um estudo de caso com estudantes da educação de jovens e adultos. Dissertação de Mestrado. Universidade Federal de Mato Grosso - UFMT. Cuiabá, 2011.

[11] MEDEIROS, C. F. Por uma Educação Matemática como intersubjetividade. In: Educação Matemática. BICUDO, M. A. V. (org). São Paulo - SP: Ed. Moraes. 2001.

[12] MORTARI, M. Educação de adultos e tecnologia. In: Danyluk, O. S. (Org). Educação de adultos: ampliando horizontes de conhecimento. Porto Alegre: Editora Sulina. 2001.

[13] NOGUEIRA, A. H. S. O tratamento dado aos conhecimentos prévios dos estudantes da Educação de Jovens e Adultos na resolução de problemas matemáticos: concepções e práticas dos professores. Dissertação de Mestrado. Universidade Federal do Mato Grosso - UFMT. Cuiabá. 2010.

[14] OLIVEIRA, A. F. B. Metacognição e resolução de problemas matemáticos na formação de professores das séries iniciais do ensino fundamental. Dissertação de mestrado. Universidade Federal do Mato Grosso - UFMT. Cuiabá. 2002.

[15] RIBEIRO, E. S. Concepções de Professores em Avaliação, Educação Matemática e Educação de Jovens e Adultos: Buscando Interfaces. Dissertação de Mestrado. Universidade Federal do Mato Grosso - UFMT. Cuiabá. 2007.

[16] THIOLLENT, M. Metodologia da pesquisa-ação. São Paulo: Cortez, 18ª ed. 2011. 


\section{ANEXO - LISTA DOS PROBLEMAS TRABALHADOS NAS AULAS INTERVENTIVAS}

\section{PRIMEIRA LISTA DE PROBLEMAS}

1- 0 salário mensal de um trabalhador é R\$2000,00, qual o valor do FGTS o empregador tem de depositar mensalmente?

2- Com base no salário de trabalhador que recebe mensalmente $\mathrm{R} \$ 2400,00$, qual será sua contribuição para o INSS?

3- Determinada loja de material de construção possui um depósito de cimento que comporta 2000 sacos, ao findar o expediente do dia o repositor observou que foi vendido $25 \%$ do total que havia no depósito. Quantos sacos de cimento foram vendidos?

4- Dona Maria é manicure e cobra $\mathrm{R} \$ 30,00$ para fazer pé e mão, sendo que o custo da matéria-prima equivale a $\mathrm{R} \$ 6,00$, qual a porcentagem equivalente ao lucro de Dona Maria em cada pé e mão?

\section{SEGUNDA LISTA DE PROBLEMAS}

1- José Antônio é vigilante noturno em uma escola, no qual faz plantão 3 vezes na semana. Quantos por cento dos dias ele trabalha na semana?

2- Em 2008 o salário mínimo era de $\mathrm{R} \$ 415,00$. Em 2018 equivale a $\mathrm{R} \$ 954,00$. Qual foi o percentual de aumento durantes esses 10 anos?

3- Um comerciante comprou 10 sacos de mandioca por $\mathrm{R} \$ 100,00$. Por quanto deve vender cada saca para obter um lucro total de $15 \%$ sobre o custo?

4. Formule um problema de porcentagem relacionado ao seu trabalho (seu dia a dia).

\section{TERCEIRA LISTA DE PROBLEMAS}

1- No pagamento à vista de uma moto usada, que custava $\mathrm{R} \$ 3.000,00$, Roberto teve um desconto de $\mathrm{R} \$ 600,00$. Quanto por cento de desconto Roberto conseguiu ao pagar a moto à vista?

2- Em uma padaria assa-se o equivalente a 10 assadeiras de pães francês no período matutino. Em um dia chuvoso a venda caiu, sobrando 6 assadeiras de pães. Quantos por cento de pães não foram vendidos?

3- Uma vendedora de trufas faz 60 unidades por dia, sendo igualmente divididas nos sabores de morango, chocolate e beijinho, ao findar o dia observa-se que não sobraram trufas com o sabor de chocolate, porém sobraram 10 unidades de beijinho e 5 unidades de morango.

a) Quantos por cento, relativo a cada sabor, foram vendidas?

b) Do total das trufas, quantos por cento foram vendidas?

\section{CRÉDITOS}

Artigo apresentado ao XIII Encontro Nacional de Educação Matemática (ENEM), realizado em 2019 na cidade de Cuibá-MT. 


\section{Capítulo 21}

Matemática e Biologia: Relatos de acessibilidade no Centro de Ciências e Planetário do Pará

\section{Sinaida Maria Vasconcelos}

Rafael Silva Patrício

Resumo: 0 presente artigo pretende relatar e refletir sobre o processo de produção e implementação de objetos de exposição, voltados para o público deficiente visual, mais especificamente nas áreas da Matemática e Biologia no Centro de Ciências e Planetário do Pará (CCPP). o CCPP atende mensalmente, em torno de 34 escolas da rede pública e privada da cidade de Belém e do interior do estado do Pará, com uma média de 1000 alunos/mês, além do público espontâneo atendido aos finais de semana, estimado em 300 pessoas/mês. Uma crescente demanda de pessoas com deficiência. Um dos resultados de tais iniciativas foi a produção dos objetos de exposição aqui descritos e analisados: Modelos didáticos em biscuit (célula animal, célula vegetal, Plasmodium sp e vaso sanguíneo); além de jogos matemáticos adaptados (torre de Hanói e quadrado mágico). Concluímos que tais iniciativas, em espaços culturais, como os centros e museus de ciências, representam significativa contribuição para que pessoas com deficiência consigam se apropriar de uma cultura científica e tecnológica, condição essencial para o exercício da cidadania na sociedade contemporânea.

Palavras-Chave: Educação Não-Formal; Acessibilidade Em Museus; Educação Científica; Cultura Científica. 


\section{INTRODUÇÃO}

A proposta de inclusão da pessoa com deficiência surgiu com a chegada do século XX, momento em que as pessoas com necessidades educativas especiais passaram a ser considerados cidadãos com direitos e deveres (GUEBERT, 2007). Isso foi expresso por intermédio dos vários documentos que surgiram, sendo o primeiro deles em 1948, no qual se torna pública a Declaração Universal dos Direitos Humanos. Com base nesse documento, as famílias dessas pessoas iniciaram alguns debates e organizaram-se, realizando, então, as primeiras críticas sobre a segregação. Assim, surgiam os movimentos em prol da inclusão.

No Brasil, a educação especial enquadrou-se no sistema geral de educação com a aprovação da Lei $\mathrm{n}^{\circ} 4.024 / 61$, contemplando o atendimento às pessoas com necessidades educativas especiais, quando possível, no sistema regular de ensino. Em estudos recentes, os anos de 1980 são considerados como a década dos tratados, época em que se originaram as primeiras declarações e tratados defendendo o processo inclusivo.

Em 1994, na Espanha, na cidade de Salamanca, houve um encontro em que participaram mais de trezentos países e mais de noventa e dois representantes da sociedade civil na discussão do tema Direito de igualdades das pessoas deficientes. A Declaração de Salamanca constitui um suporte para elaboração de uma série de dispositivos legais, no Brasil, e em outros países, para construção de uma sociedade inclusiva e solidária.

A Convenção Internacional sobre os Direitos das Pessoas com Deficiência, assinada em 2007, em Nova York e promulgada como emenda à Constituição Federal do Brasil pelo decreto no 6.949, de 25 de agosto de 2009, determina que nenhuma pessoa pode sofrer qualquer tipo de discriminação tendo como justificativa a deficiência, assumindo a deficiência como "um conceito em evolução" resultante "da interação entre pessoas com deficiência e as barreiras devidas às atitudes e ao ambiente que impedem a plena e efetiva participação dessas pessoas na sociedade em igualdade de oportunidades com as demais pessoas" (BRASIL, 2009).

Sob essa ótica, compreende-se a deficiência não como um problema da pessoa, mas que nasce da sua relação com o entorno, na medida em que o mesmo estabelece barreiras à sua participação. Assim, garantir acessibilidade pressupõe minimizar ou eliminar tais barreiras, que de acordo com o Estatuto da Pessoa com Deficiência - No. 13.146, de 06 de julho de 2015 representam:

Qualquer entrave, obstáculo, atitude ou comportamento que limite ou impeça a participação social da pessoa, bem como o gozo, a fruição e o exercício de seus direitos à acessibilidade, à liberdade de movimento e de expressão, à comunicação, ao acesso à informação, à compreensão, à circulação com segurança. (Artigo $3^{\circ}$ )

0 acesso do cidadão aos bens culturais está incluso na dita participação social da pessoa. Entretanto, mesmo nas sociedades em que o direito legal de acesso está garantido, a transformação desse direito em prática social cidadã, ainda constitui uma conquista em construção. Nesse cenário de construção e conquistas do direito ao acesso aos bens culturais os Museus representam importante espaço para aquisição da dita cultura científica, representando um desafio que se pretende ser gradualmente enfrentado e superado.

A partir da promulgação do Estatuto de Museus, ocorrida em 2009, o Conselho Nacional de Museus (CNM) passou a adotar o conceito de museu expresso na Lei no 11.904, de 14 de janeiro, de acordo com o qual:

Consideram-se museus, para os efeitos desta Lei, as instituições sem fins lucrativos que conservam, investigam, comunicam, interpretam e expõem, para fins de preservação, estudo, pesquisa, educação, contemplação e turismo, conjuntos e coleções de valor histórico, artístico, científico, técnico ou de qualquer outra natureza cultural, abertas ao público, a serviço da sociedade e de seu desenvolvimento. (Artigo $1 \stackrel{\circ}{\circ}$ )

Ao estar em serviço à sociedade e ao seu desenvolvimento os museus apresentam dentre suas características: a presença de acervos e exposições colocados a serviço da sociedade com o objetivo de propiciar a ampliação do campo de possibilidades de construção identitária, a percepção crítica da realidade, a produção de conhecimentos e oportunidades de lazer; a utilização do patrimônio cultural como recurso educacional, turístico e de inclusão social; e a democratização do acesso, uso e produção de bens culturais para a promoção da dignidade da pessoa humana. 
Sendo assim, são considerados museus, independentemente de sua denominação, as instituições ou processos museológicos que apresentem entre as suas características as acima indicadas e cumpram as funções museológicas.

Assim documentos que regulam o planejamento e organização dos museus e centros de ciências têm incorporado e estabelecido princípios visando garantir a acessibilidade das PCDs a esses espaços culturais.

O Plano Nacional Setorial de Museus (PNSM - 2010/2020) estabelece dentre suas diretrizes que os museus brasileiros devem: Promover a democratização da instituição museológica, dos sistemas e das redes museais por meio da participação comunitária e de ações extramuros visando à interação com os diversos grupos sociais: étnicos, tradicionais, populares e outros (BRASIL, 2010, P.46). Na busca por alcançar a meta de democratização dos espaços o referido documento estabelece como estratégias: promover a acessibilidade de pessoas com deficiência, por meio de programas e ações educativas, além de atenção com a estrutura física da instituição considerando a demanda representada pelas pessoas com deficiência.

O PNSM também apresenta como diretriz: Estabelecer uma política de acessibilidade universal para museus e centros culturais. Apontando como estratégia associada a tal diretriz: Estimular a criação de legislação e produzir orientações sobre acessibilidade para museus e centros culturais. Indicando como ação: Criar e implementar normas e procedimentos específicos para museus e centros culturais para garantir acessibilidade universal (física, intelectual, estética e sensorial), em consonância com o Decreto 5.296/2004 e as normas de acessibilidade já existentes no país. (BRASIL, 2010, p.57)

Outra estratégia apresentada pelo PNSM diz respeito a: Garantir o acesso a pessoas com deficiência, com mobilidade reduzida e em situação de vulnerabilidade social aos museus e centros culturais. As ações correspondentes ao alcance dessa meta seriam: Adequar os espaços museais e seu entorno aos princípios da acessibilidade universal; Elaborar estratégias de comunicação que favoreçam a compreensão dos discursos expositivos (conteúdo, forma e meios) pelos visitantes e potenciais visitantes. (BRASIL, 2010, p. 58)

O Plano Museológico é considerado ferramenta de planejamento estratégico, norteador das ações a serem desenvolvidas pelos museus no cumprimento de sua função social. Para subsidiar a construção desse importante documento, que baliza a trajetória dos museus, o Instituto Brasileiro de Museus (IBRAM) publicou em 2016 o documento Subsídios para elaboração de Projetos Museológicos. 0 referido documento define 12 programas que deverão constituir um Plano Museológico, sendo um deles o Programa de Acessibilidade Universal.

O Programa de Acessibilidade Universal reconhece como espaços inclusivos e acessíveis aqueles que, mesmo que gradativamente, implementes medidas de acessibilidade, definindo seis dimensões de acessibilidade que deverão existir nos ambientes do museu, com vistas a "circulação autônoma de qualquer tipo de pessoa, seja ela com ou sem deficiência: arquitetônica, metodológica, instrumental, programática, atitudinal e comunicacional". (BRASIL, 2016, p. 98)

A acessibilidade arquitetônica materializa oposição às barreiras físicas que dificultam ou impedem o acesso de pessoas com deficiência, ou mobilidade reduzida. A acessibilidade metodológica corresponde aos métodos de ensino, trabalho e lazer aplicados a quaisquer tipos de pessoas. A acessibilidade instrumental diz respeito a disponibilização de instrumentos e utensílios com vistas ao atendimento às limitações de algum tipo de deficiência. A acessibilidade programática representa contraposição as chamadas "barreiras invisíveis", ou seja, barreiras que se apresentam de forma implícita, dificultando o direito de ir e vir de pessoas com deficiência, ocorrendo em situações em que as políticas públicas não respeitam, ou garantem os direitos desses cidadãos.

Por acessibilidade atitudinal entende-se o zelo e cumprimento dos direitos das pessoas com deficiência, superando barreiras baseadas em preconceitos ou deles originadas, representadas por ações, ou omissões. A acessibilidade comunicacional pode ser compreendida como os vários tipos de linguagem a serem empregados no atendimento ao público com, ou sem, deficiência (linguagem de sinais, linguagem corporal, braile, áudio-descrição, etc)

O caminhar e o avanço da ciência passam por processos outros que diferem dos habituais. 0 rigor de cada ciência, denota respeito, conservação e fundamentação à princípios já estabelecidos e fixados ao longo dos tempos. A ciência também é acompanhada do fato de tornar-se útil, acessível e popular, também, como forma de auxiliar na resolução de problemas vindouros da vivência coletiva. Para tanto, faz-se necessário historicizar, testar, provar, expor e, também, popularizar. 
Tornar a ciência acessível a todos é pôr a prova que o que se produz em laboratórios, universidades, museus, centros de ciência, bem como espaços não formais de ensino; visa assistir à população que, de muitas formas, não tem acesso ao que se é feito nesses espaços. Locais como os citados anteriormente, estão repletos de conhecimento que desejam ter maior acesso e, para tanto, devem investir na acessibilidade da informação, do espaço e do saber.

Na busca pela popularização da Ciência, assumindo os princípios da acessibilidade universal, o Centro de Ciências e Planetário do Pará (CCPP), da Universidade do Estado do Pará, vem buscando adequar seu discurso expositivo, diversificando-o em seu conteúdos, formas e meios, para assim atender a diversidade do público atendido pelas suas ações.

As ações desenvolvidas pelo CCPP são pensadas e implementadas a partir das áreas temáticas em que os espaços se encontram estruturados: Biologia, Física, Química, Matemática, Astronomia e Geologia. Tais ações estão representadas por: palestras, oficinas, observações astronômicas, programas de cúpula e visitação livre ou monitorada. Todas as atividades são executadas por uma equipe multiprofissional, composta por professores, técnicos e estagiários, que trabalham a partir dos princípios da interdisciplinaridade, interatividade e ludicidade.

Atualmente o CCPP atende, mensalmente, em torno de 34 Escolas da Rede Pública e Privada da cidade de Belém e do interior do estado do Pará, com uma média de 1000 alunos/mês, além do público espontâneo atendido aos finais de semana, estimado em 300 pessoas/mês. No ano de 2016 o CCPP foi o terceiro museu mais visitado da região norte e o mais visitado do estado do Pará, considerando-se para tal classificação museus de toda e qualquer natureza (histórico, de arte, etc).

0 presente artigo pretende relatar e refletir sobre a produção e implementação de objetos de exposição, voltados para o público deficiente visual, mais especificamente nas áreas da Matemática e Biologia.

\section{METODOLOGIA}

O presente estudo apresenta os resultados de um projeto do Grupo de Pesquisa Ciência, Tecnologia, Meio Ambiente e Educação Não-formal (CTENF), que concentra seus estudos e pesquisas na aréa da educação não-formal, em específico na educação em museus de ciências, caso do Centro de Ciências e Planetário do Pará, ao qual a maioria de seus membros se encontra institucionalmente vinculados.

A gênese do projeto remonta ao ano de 2013 quando foram produzidos os primeiros modelos de células táteis, na busca por facilitar a compreensão de estruturas de dimensões microscópicas, ou seja, somente possível de serem observadas, pelos indivíduos videntes através do microscópio, equipamento esse que não apresenta possibilidade de uso pelos deficientes visuais.

A partir dessa primeira iniciativa, estudos e proposições foram desenvolvidos para outras temáticas relacionados a área da Biologia e posteriormente para outras áreas. Os estudos ganharam uma proporção, de tal forma que as proposições e ações começara a se articular até que, em 2017, assumissem a configuração de um Plano de Ação - CCPP acessível, cujo objetivo é viabilizar ações e estratégias que promovam de fato e direito o processo de inclusão de pessoas com deficiência.

Dentre as ações e estratégias previstas no plano podemos destacar: Palestra e workshop (Sensibilização, Inclusão, Acessibilidade, Audiodescrição); Parcerias para estágio voluntário de intérprete de libras; Identificação dos espaços e materiais em braile, além de adaptações estruturais e do acervo.

No presente artigo apresentaremos especificamente o material de exposição adaptado para deficientes visuais, produzido nas áreas de Matemática e Biologia.

\section{RESULTADOS E DISCUSSÃO}

Nesta seção apresentaremos o relato do processo de concepção, produção e aplicação dos materiais adaptados para pessoas cegas ou com baixa visão, que fazem parte do material de exposição das áreas de Matemática e Biologia do Centro de Ciências e Planetário do Pará. 


\section{MATEMÁTICA ACESSÍVEL}

No Espaço da Matemática do CCPP o visitante pode aprender sobre os conceitos de adição, subtração, multiplicação e divisão, além de conhecer objetos que estimulam o pensamento geométrico, raciocínio lógico e matemático. Tais conceitos são apresentados através de jogos matemáticos. 0 visitante aprende de forma divertida e lúdica sobre a matemática e como ela pode estar presente em nosso cotidiano.

O espaço também disponibiliza computadores touchscreen contendo diversos jogos matemáticos, para aqueles que se interessam pela tecnologia computacional. Além de contar uma pequena parte da história da matemática por meio de um painel com alguns dos mais célebres matemáticos e suas principais contribuições para o desenvolvimento da matemática em nossa sociedade.

Com o intuito de ampliar o acervo e as possibilidades de acessibilidade ao material matemático, estão sendo produzidos recursos adaptados para o atendimento do público com deficiência visual. Aqui daremos destaque para: Torre de Hanói e Quadrado Mágico adaptados.

1- Torre de Hanói adaptada: 0 material produzido na área da Matemática teve por objetivo geral proporcionar ao deficiente visual, através de jogos matemáticos, a compreensão da função exponencial. Para tanto, as peças são representadas por formas geométricas como triângulo, quadrado, pentágono, hexágono e heptágono, ou seja, figuras que possuem quantidades de lados diferentes entre si, favorecendo a percepção tátil e a distinção entre as formas citadas, caracterizando assim, a torre de Hanói adaptada (Figura 1).

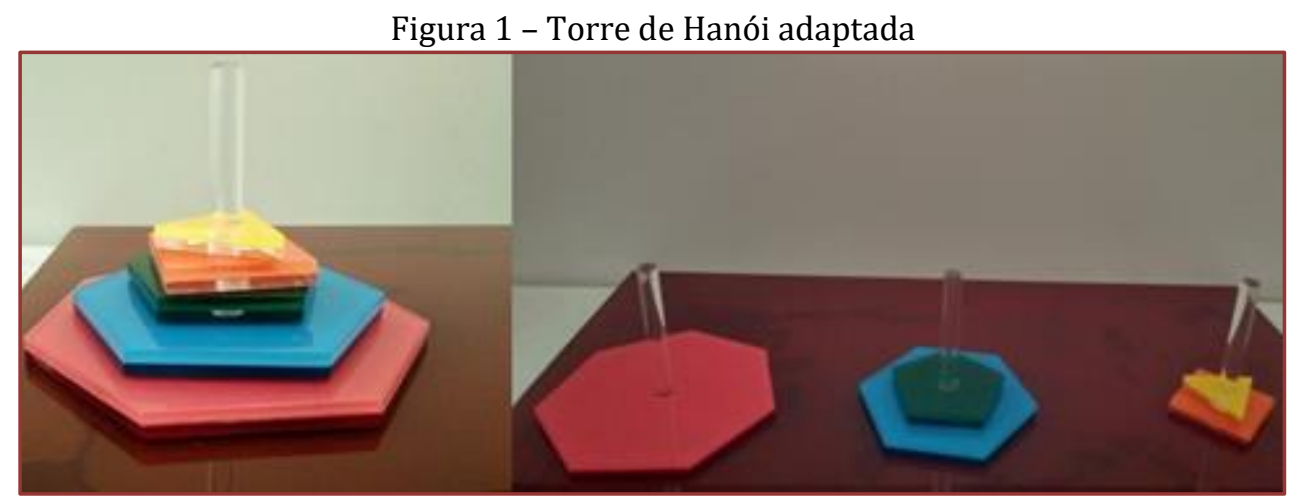

Fonte: Arquivo dos autores

2- Quadrado Mágico: dispõe de números imantados para alocação dos mesmos em forma de linhas e colunas, somando-os 10 unidades. Assim, trabalha-se a operação soma, distinção de linhas e colunas, bem como o sentido táctil (Figura 2).

Figura 2 - Quadrado Mágico adaptado

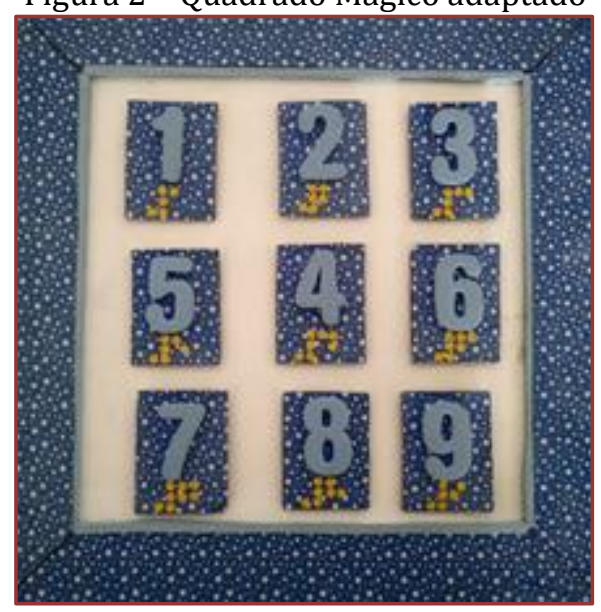

Fonte: Arquivo dos autores 
Os jogos ou brinquedos educativos ao se constituirem em recursos que ensinam de maneira prazerosa, como é o caso da torre de Hanói e do quadrado mágico, evidenciam a relevância desse tipo de material em situações tanto da educação formal, quanto não-formal, ao possibilitar: a ação intencional (afetividade); a manipulação de objetos e o desempenho de ações sensório-motoras; a construção de representações mentais; e trocas sociais, ou seja as interações entre diferentes (Kishimoto, 2007).

Compreendido assim, o uso do brinquedo ou jogo educativo no atendimento à pessoas com deficiência visual, no ambiente da Matemática do CCPP, se revelou como possibilidade de torná-lo mais acessível, contribuindo para tornar o museu mais acolhedor para todas as pessoas, fazendo com que este equipamento que sempre esteve ligado à elite e ao tradicionalismo se torne uma opção de lazer para toda a população (SARRAF, 2013).

\subsection{BIOLOGIA ACESSÍVEL}

Os conteúdos da disciplina escolar Biologia apresentam de uma maneira geral caráter bastante abstrato, se considerarmos as dimensões microscópicas das diversas estruturas, organismos e fenômenos estudados. Apesar da abstração e dificuldade de visualização das estruturas em nível celular e molecular, tais conteúdos são trabalhados no cotidiano das salas de aula quase que exclusivamente a partir da utilização de livros e/ou apostilas com figuras estáticas.

No CCPP existem três espaços expositivos da área da Biologia: Origem da Vida; Biodiversidade e Bioculturalidade; e Doenças Tropicais e o Homem. Em especial nos dois últimos citados, são abordadas temáticas associadas a estruturas microscópicas, o que representa obstáculo para os deficientes visuais.

A alternativa encontrada para minimizar a dificuldade enfrentada por esses visitantes em especial, foi a produção de modelos didáticos em biscuit que apresentam essas estruturas em dimensões ampliadas, possibilitando a identificação de sua forma e organização através do toque. E foi nessa perspectiva que professores e estudantes de Biologia do CTENF propuseram a produção e incorporação ao acervo de exposição do CCPP dos seguintes modelos didáticos:

1- Célula animal e vegetal em biscuit: No espaço de exposição identificado como da Biodiversidade e Bioculturalidade encontram-se em exposição materiais que representam a diversidade de espécies existentes em nosso planeta, sendo apresentados desde fundamentos básicos acerca da sua organização - estrutura celular, até representantes de diversas espécies dos reinos animal e vegetal.

A percepção da estrutura celular animal e vegetal para o deficiente visual é facilitada pela utilização de modelos didáticos desses tipos celulares, construídos em biscuit (Figura 3)

FIGURA 3 - Modelos - Célula Animal (A) e Célula Vegetal (B)

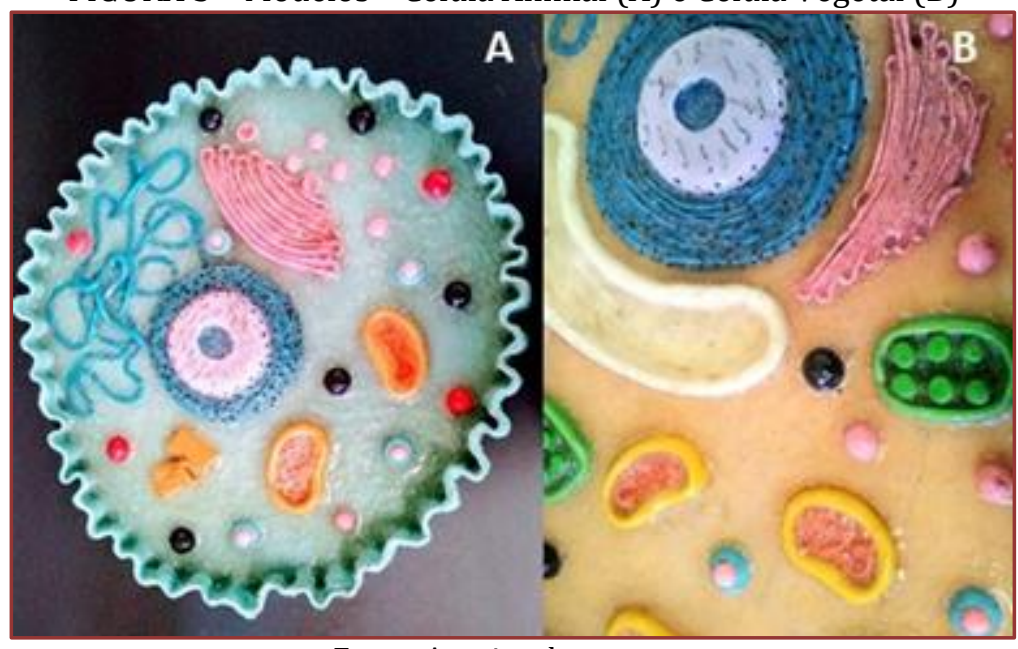

Fonte: Arquivo dos autores 
2- $\quad$ Plasmodium em biscuit: No espaço de Doenças Tropicais e o Homem encontra-se material representativo da organização do corpo humano, desde a estrutura molecular até os diversos sistemas, além de possuir informações sobre os principais agentes e vetores de doenças comuns à região Amazônica como a Doença de Chagas, Malária, Dengue, Tuberculose e Hanseníase.

Com o intuito de possibilitar aos deficientes visuais acesso às informações referentes aos agentes causadores dessas doenças, foram produzidos, e encontram-se em exposição, modelos didáticos, como o do Plasmodium - protozoário causador da Malária (Figura 4). Além dos modelos, são expostas algumas amostras de vetores (insetos) preservados em meio líquido, que podem ser visualizadas através do uso de lentes de aumento.

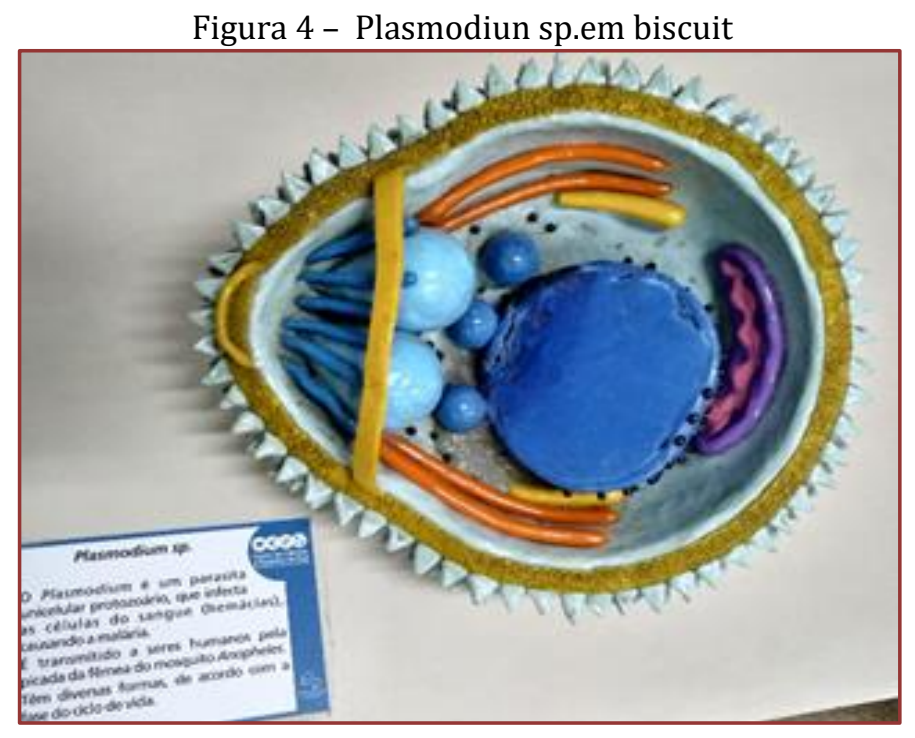

3- Vaso sanguíneo em biscuit: No que diz respeito a temática da organização do corpo humano, além de recursos tradicionalmente empregados no ensino de Biologia (torso e esqueleto humano), para apresentação de estruturas microscópicas também se lançou mão do uso do modelo didático em biscuit, como foi o caso do modelo de vaso sanguíneo em que se encontram representados inclusive os componentes celulares do sangue humano (Figura 5).

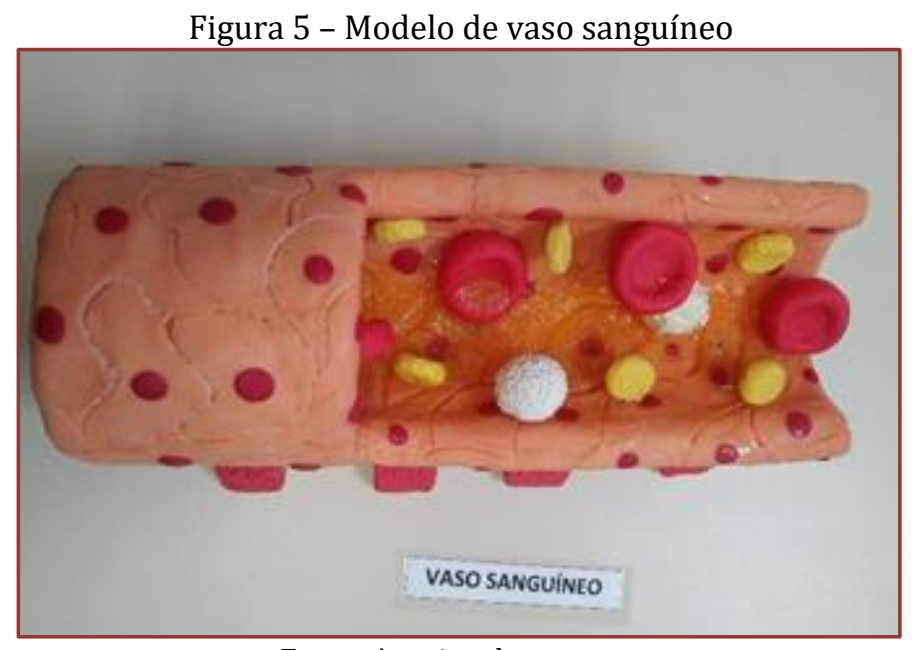

Fonte: Arquivo dos autores 
Os recursos aqui apresentados constituem uma alternativa para abordagem de conteúdos com elevado nível de abstração, ao possibilitarem o contato direto com estruturas tridimensionais ou semi-planas (alto relevo) e coloridas, que facilitariam a compreensão de estruturas e organismos microscópicos, permitindo que o deficiente visual manipule o material, reconhecendo-o de vários ângulos, melhorando, assim, sua compreensão sobre o conteúdo abordado. Diante do exposto evidencia-se a utilização dos modelos didáticos como valioso instrumento facilitador para esse público.

Obras táteis são fundamentais para as pessoas com deficiência visual, causando um prazer muito grande na sua experiência de visita a um museu (COHEN et al., 2012). A implementação de tais medidas de acessibilidade vem permitindo às pessoas com deficiência utilizarem os espaços da Matemática e da Biologia/CCPP de maneira mais autônoma, fácil e segura, tornando-os observáveis e vivenciáveis de formas diversificadas.

\section{CONSIDERAÇÕES FINAIS}

O desafio ao qual se lançou toda a equipe do CCPP, e do grupo CTENF busca ir ao encontro dos anseios de um segmento importante da população brasileira - as pessoas com deficiência, além de ecoar um anseio de significativa parcela da sociedade, na busca por tornar-se mais plural e democrática. Pluralidade e democratização que passam pela socialização de saberes, e também pela inclusão de pessoas com deficiência aos mais diversificados espaços de cultura, ciência e tecnologia.

Iniciativas, como as aqui relatadas, cuja intenção é promover maior acessibilidade das pessoas com algum tipo de deficiência aos espaços culturais, como os centros e museus de ciências, representam, portanto, significativa contribuição para que essas pessoas consigam se apropriar de uma cultura científica e tecnológica, condição essencial para o exercício da cidadania na sociedade contemporânea.

Assim, tornar um museu acessível, envolve iniciativas que vão para além de possibilitar o acesso ao prédio em que está abrigado o acervo do museu, mas possibilitar que esse acervo se apresente sob diferentes formas, permitindo a popularização da ciência, tendo em vista que com ele interagem públicos diversos.

Por fim, destaca-se a importância de que o compromisso efetivo com a mudança da realidade atual, no sentido de avançar rumo a inclusão cultural de todas as pessoas, inclusive aquelas com deficiência, passa pelo compromisso de que instituições como museus e centros de ciências, para que estejam envolvidos na discussão e debate do tema da acessibilidade, contribuindo assim, para construção de uma sociedade mais justa, igualitária e que respeite a diversidade.

\section{REFERÊNCIAS}

[1] BRASIL. Decreto no 6949, de 25 de agosto de 2009. Promulga a Convenção Internacional sobre os Direitos das Pessoas com Deficiência e seu Protocolo Facultativo, assinados em Nova ork, em 30 de março de 2007. Brasília, 2009.

[2] CHASSOT, A. Educação consciência. EDUNISC, 2003.

[3] CASTRO, J. A. de Evolução e desigualdade na educação brasileira. Educação \& Sociedade, v. 30, n. 108, 2009.

[4] COHEN, R.; DUARTE, C.; BRASILEIRO, A. Acessibilidade a Museus. Brasília, DF: MinC/Ibram, 2012. (Cadernos Museológicos Vol.2)

[5] KISHIMOTO, T. M. O jogo, brinquedo, brincadeira e a educação. São Paulo: Editora Cortez, 2007.

[6] SARRAF, Viviane Panelli. A Comunicação dos Sentidos nos espaços culturais brasileiros: estratégias de mediações e acessibilidade para pessoas com suas diferenças. Tese de Doutorado. USP, 2013.

[7] BRASIL. Declaração de Salamanca e linha de ação sobre necessidades educativas especiais. Brasília: UNESCO, 1994.

Plano Nacional Setorial de Museus - 2010/2020. Ministério da Cultura, Instituto Brasileiro de Museus. - Brasília, DF: MinC/Ibram, 2010.

Subsídios para elaboração de planos museológicos. Brasília: Instituto Brasileiro de Museus - IBRAM. 2016. 112 p : il.

Lei No. 13.146, de 06 de julho de 2015. Disponível em> http://www.planalto.gov.br/ccivil_03/_ato20152018/2015/lei/l13146.htm. Acesso em: 14, de abril, 2019.

Declaração Universal dos Direitos Humanos. Disponível em: http://www.dudh.org.br/wpcontent/uploads/2014/12/dudh.pdf. Acesso em: 13, de abril, 2019.

[8] GUEBERT, M. C.C. Inclusão: uma realidade em discussão. 2. Ed.- Curitiba: Ibpex, 2007. 


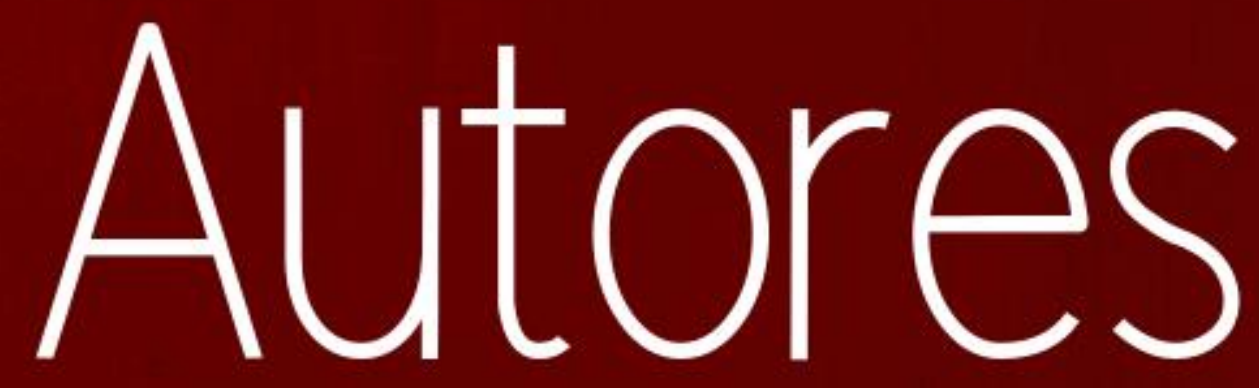




\section{ADRIANA FLÁVIA NEU}

Mestra em Educação pelo Programa de Pós-Graduação em Educação da Universidade Federal de Santa Maria (UFSM). Especialista em Gestão Educacional pelo Programa de Pós-Graduação em Políticas Públicas e Gestão Educacional da UFSM. Licenciada em Educação Física pela UFSM. Professora de Educação Física da Rede Pública Municipal de Faxinal do Soturno/RS e Tupanciretã/RS.

\section{ALBERES LOPES DE LIMA}

Bacharel em Física pela UFPE (1995) e Licenciado em Ciências pela UFRPE (1990). Tem pósgraduação nas áreas de Ensino de Física (UNICSUL), Ensino de Matemática (UFF) e Gestão da Administração Pública (UCB). Em 1999, concluiu o mestrado em Física pela UFPE. Em 2008, concluiu o Doutorado em Física pela UFPB.

\section{ALEKSANDRE SARAIVA DANTAS}

Graduação em Ciências com Habilitação em Matemática pela Universidade do Estado do Rio Grande do Norte (1994), Especialização em Educação (linha de pesquisa: formação do professor) (1999) pela Universidade do Estado do Rio Grande do Norte. Mestrado em Engenharia de Produção (linha de pesquisa: Educação a Distância) pela Universidade Federal de Santa Catarina (2001). Mestrado Profissional em Matemática (PROFMAT) pela Universidade Federal Rural do Semiárido (UFERSA). Doutorado pelo Programa de Pós-graduação em Educação da Universidade Federal do Rio Grande do Norte.

\section{ANA CLAUDIA DE ANDRADE COSTA}

Graduada em Licenciatura Interdisciplinar em Educação do Campo com habilitação em Ciências Humanas e Sociais pela Universidade Federal Rural do Semi-Árido. Atualmente é estudante do programa de Pós-Graduação interdisciplinar em Ciências humanas e Sociais, pela Universidade do Estado do Rio Grande do Norte (UERN). É também estudante do programa de Pós-Graduação em Cognição Tecnologia e Instituições pela Universidade Federal Rural do Semi-Árido (UFERSA). Trabalha com discussões de Gênero, Cultura Popular, História e Memória com ênfase em Educação.

\section{ANA GABRIELA ALVES MEDEIROS}

Licenciada em Educação Física pela Universidade Estadual de Santa Cruz (UESC-BA). Membro do Grupo de Pesquisa em Práticas Pedagógicas em Educação Física Escolar e Esporte (GPEFE/UESC) e do Grupo de Pesquisa em Educação Física, Esporte e Lazer (AGENTE/UNEB). Pós-graduada em Gestão Esportiva pelo Centro Universitário Claretiano. Mestre em Educação Física pelo Programa de Pós Graduação em Educação Física da Universidade Federal do Espírito Santo (UFES). Doutoranda em Ciências do Desporto na Universidade do Porto. Professora da Universidade do Estado da Bahia (UNEB - Campus XII).

\section{ANA PAULA PINHEIRO DA SILVEIRA}

Professora Adjunta I da Universidade Tecnológica Federal do Paraná (UTFPR), com Doutorado em Estudos da Linguagem pela Universidade Estadual de Londrina (2013), Mestrado em Linguística pela Universidade Federal de Santa Catarina (2004), Graduação em Letras - Língua Portuguesa e Literaturas - pela Universidade do Estado do Rio de Janeiro (1991). A pesquisadora é docente do Programa de Pós-Graduação em Estudos das Linguagens/PPGEL, do Departamento de Linguagem e Comunicação, membro do Grupo de Pesquisa em Linguística Aplicada (GRUPLA), e desenvolve pesquisas na área de Multiletramentos, Práticas de leitura e escrita na contemporaneidade, semiótoca tecnologia e ensino. 


\section{ANICÉZIA PEREIRA ROMANHOL BETTE}

Mestre em Literatura Brasileira pelo Centro de Ensino Superior de Juiz de Fora, com especialização em Literatura Brasileira PUC (MG). Atualmente é professora efetiva da UEMG - Universidade Estadual de Minas Gerais, onde ministra aulas no curso de Pedagogia e é membro do colegiado e do NDE. Além disso, coordena o PIBID desde 2016. Também criou e coordena o grupo de Contação de história da UEMG - Leopoldina, denominado "Conto Sonoro". Os projetos de extensão e de pesquisa são voltados para a formação do leitor por meio das rodas de leitura literárias, contação de histórias e letramento literário desde a creche ao ensino médio. Em IES privada, ministrou aulas em cursos de especialização em Letras; Gestão Empresarial e Gestão Ambiental; e Responsabilidade Social. Coordenou o Curso de pós-graduação em Língua, Linguagem e Literatura na sala de aula, bem como graduação de Letras. Também coordenou o setor de Extensão, Responsabilidade Social e Iniciação Científica. Criou o grupo de Contação de História e Rodas de Leitura: Ktaletras. Possui livros publicados na área de literatura local e infantil, sendo a linha de pesquisa voltada para a formação do leitor por meio da literatura. Leciona desde os 16 anos e perpassou por várias etapas da educação básica (Educação Infantil, Ensino Fundamental, Ensino Médio, Superior e especializações, em escolas públicas e privadas). Possui contos, poesias, artigos e ensaios publicados em revistas acadêmicas e jornais. Ministra palestras relacionadas ao Ensino de Língua Portuguesa e de Literatura, cursos de capacitação em empresas, na área de Comunicação empresarial. Recebeu cinco premiações como professora-orientadora em Concursos de Redação do Sistema de Formação Gerencial Sebrae, BH - MG. No ano de 2008, recebeu menção honrosa por orientar a acadêmica, Rita de Cássia Mendes Cabral, vencedora do 14ํㅜ Prêmio Nacional Assis Chateaubriand de Redação, Projeto Memória, categoria Ensino Universitário. Em 2016 recebeu Diploma da Comenda do mérito

\section{CLAUDIA SANTOS MARTINIANO}

Possui graduação em Enfermagem (Bacharelado e Licenciatura) pela Universidade Estadual da Paraíba (1994). Especialista em Saúde da Família (UEPB). Especialista em Pediatria e Puericultura (UEPB). Mestrado em Saúde Coletiva (UEPB/2006). Doutorado em Ciências da Saúde pela Universidade do Rio Grande do Norte. É professora efetiva do Departamento de Enfermagem da UEPB. É uma das líderes do Grupo de Pesquisa, Estudos e Assessoria em Políticas e Programas de Saúde e pesquisadora do Grupo de Estudos em Saúde Coletiva (UFRN). É Professora efetiva do Mestrado em Saúde Pública da UEPB e do Mestrado em Saúde da Família da Rede Nordeste de Saúde da Família.

\section{CRISTIANO BERTOLINI}

Doutor em Ciência da Computação pela UFPE - Universidade Federal de Pernambuco. Professor Adjunto do Departamento de Tecnologia da Informação da UFSM - Universidade Federal de Santa Maria - Campus Frederico Westphalen/RS.

\section{DÉBORA FURTADO BARRERA}

Doutoranda em Educação pela Universidade de Brasília(UnB), na linha de Estudos Comparados em Educação(ECOE). Mestre em Educação (UnB). Especialista em Educação a Distância (UnB) e em Design Instrucional para cursos a distância pela Universidade Federal de Itajubá (UNIFEI). Pedagoga formada pela UnB. Experiência nas áreas de gestão de cursos a distância, de formação inicial e continuada de professores e na área elaboração de materiais didáticos para cursos a distância. Bacharel em Direito pela Universidade Católica de Brasília (UCB). 


\section{DELANY RAMOS DE SOUSA}

Possui graduação em LICENCIATURA EM MATEMÁTICA pelo Instituto Federal do Piauí (2009), Especialização em Língua Brasileira de Sinais, cursando o nono período de Engenharia Mecânica no IFPI, Curso de Formação em Tradução Interpretação em Língua Brasileira de Sinais, Certificação de Proficiência no Ensino da Libras. Atualmente é tradutora de Língua Brasileira de Sinais Libras/português no IFPI, professora de matemática e libras em Teresina, Professora da disciplina de Libras no curso de formação de sargentos da Polícia Militar do Piauí, professora de Libras em cursos de pós-graduação na UFPI e em Faculdades. Atuou também em bancas de de Tccs em cursos de Licenciaturas e pós graduações e bancas de formação de Intérpretes de Libras.

\section{DENIS RODRIGUES DANTAS}

Mestre em Geografia pela Universidade Federal do Rio Grande do Norte

\section{DINALVA CLARA MONTEIRO SANTOS SILVA}

Possui graduação em Licenciatura Plena em Letras/Português pela Universidade Federal do Piauí (1991), especialização em Língua Portuguesa pela Pontifícia Universidade Católica de Minas Gerais (1996) e Mestrado em Educação pela Universidade Federal do Piauí (2006). Atualmente é professora efetiva do Instituto Federal de Educação Ciência e Tecnologia do Piauí. Doutoranda em Educação na Universidade Federal do Piauí.

\section{EDICARLOS MEDEIROS BATISTA}

Técnica em Informática pelo Instituto Federal de Educação, Ciência e Tecnologia do Rio Grande do Norte.

\section{ELYS REGINA ZILS}

Possui graduação em Letras - Espanhol (Licenciatura) pela Universidade Federal de Santa Catarina (2013) e mestrado em Estudos da Tradução pela Universidade Federal de Santa Catarina (2015). Áreas de atuação: Tradução - teoria e prática, Literatura Latino-Americana pesquisando principalmente Vanguardas Literárias e Artísticas com ênfase em Literatura Surrealista Latinoamericana. Experiência como tutora/professora na área de Educação e desenvolvimento de materiais para EAD.

\section{ERIKA CABRAL GUIMARÃES}

Possui graduação em Design Industrial pela Universidade Federal da Paraíba (1984), Especialização em Visual Communication pela University of Central England - Birmingham - Reino Unido (1993), Especialização em Metodologia do Ensino Superior pelo Centro de Ensino Superior e Desenvolvimento - Unifacisa (2017),Especialização em design de Interiores pelo Centro de Ensino Superior e Desenvolvimento - Unifacisa (2019). Mestrado em Visual Communication pela University of Central England - Birmingham - Reino Unido (1994) e aperfeiçoamento em The Further and Adult Education TeachersCertifica pela Bournville College Of Further Education - Birmingham - Reino Unido (2001).

\section{FÁBIO JOSÉ PARREIRA}

Doutor em Engenharia Elétrica pela UFU - Universidade Federal de Uberlândia. Professor Associado do Departamento de Tecnologia da Informação da UFSM - Universidade Federal de Santa Maria Campus Frederico Westphalen/RS 


\section{FRANCISCO GENIVAN SILVA}

Possui graduação em Ciência da Computação pela Universidade do Estado do Rio Grande do Norte (2007), especialista em Desenvolvimento de Sistemas Corporativos e Mestre em Sistemas e Computação pela UFRN. Atualmente é professor de Sistemas de Informação do Instituto Federal do Rio Grande do Norte. Possui com áreas de interesse Sistemas de Informação, Informática e Educação e Learning Analytics

\section{FRANCISCO PEREIRA DE ANDRADE}

Licenciado em Matemática pela Universidade Federal do Rio Grande do Norte - UFRN (2012), Mestre em Matemática (2015) - Universidade Federal Rural do Semi-Árido (UFERSA), Doutorando - UFRN - Engenharia de Petróleo (2015). Atualmente fazendo uma especialização em educação financeira pela UFPB virtual.

\section{FRANCISCO WAGNER DE SOUSA PAULA}

Enfermeiro e Biólogo. Mestre em Cuidados Clínicos em Enfermagem e Saúde pela Universidade Estadual do Ceará (UECE).Especialista em Gestão em Saúde pela Universidade Estadual do Ceará (UECE). Professor do Centro Universitário Maurício de Nassau - Sede Parangaba. Professor Efetivo da Rede Básica de Ensino da Secretaria de Educação do Estado do Ceará (SEDUC/CE). Professor Formador e Tutor a distância do curso de Licenciatura em Ciências Biológicas (UECE/UAB) e Enfermeiro do Hospital e Maternidade Regional Vale do Curu, Pentecoste-Ce.

\section{GEOVÂNIA SILVA MOTA}

Licenciada em Educação Física pela Universidade do Estado da Bahia - UNEB/DEDC - CAMPUS XII. Professora da Rede Municipal de Ensino de Ituiutaba/Minas Gerais.

\section{GERMANA COSTA PAIXÃO}

Graduada em Medicina Veterinária pela Universidade Estadual do Ceará (1997), Mestre em Patologia pela Universidade Federal do Ceará (2000) e Doutoranda em Microbiologia Médica/UFC desde 2018. Professora da Universidade Estadual do Ceará desde 2000 e Coordenadora do Curso de Ciências Biológicas a distância UECE/Universidade Aberta do Brasil (UAB) desde 2009. Docente do curso de Enfermagem do Centro Universitário Unifametro. Leciona as disciplinas de Microbiologia, Parasitologia e Exames Laboratoriais. É líder do grupo de pesquisas certificado pelo CNPq, intitulado "Tecnologias educacionais e educação a distância" desenvolve pesquisas nas áreas de taxonomia de dermatófitos, fungos anemófilos e produção de material em Microbiologia.

\section{GUILHERME BERNARDINO DA CUNHA}

Doutor em Engenharia Elétrica pela UFU - Universidade Federal de Uberlândia. Professor Adjunto do Departamento de Tecnologia da Informação da UFSM - Universidade Federal de Santa Maria Campus Frederico Westphalen/RS

\section{ISABEL DILLMANN NUNES}

Possui graduação em Ciência da Computação pela Universidade Federal de Pelotas (1998), mestrado em Ciência da Computação pela Universidade Federal do Rio Grande do Sul (2001) e doutorado em Ciência da Computação pela Universidade Federal de Campina Grande (2014). Tem experiência na área de Ciência da Computação, atuando principalmente nos seguintes temas: Engenharia de Software e Informática na Educação. Atualmente é professora do Instituto Metrópole Digital da UFRN (Natal - RN). 


\section{ISADORA AZEVEDO MEDEIROS DO NASCIMENTO}

Técnica em Informática pelo Instituto Federal de Educação, Ciência e Tecnologia do Rio Grande do Norte

\section{JAILDO ASSIS DA SILVA}

Doutorando em Ciências da Educação na Universidade Columbia Del Paraguay), Mestre em Ciência da Educação e Interdisciplinaridade pela Universidade Gama Filho (2015), Pós-graduação Curso de Especialização em Ensino de Matemática da Universidade Federal Rural de Pernambuco (UFRPE), Graduação em Licenciatura Plena em Matemática na Fundação de Ensino Superior de Olinda (FUNESO).

\section{JEFFERSON FELLIPE JAHNKE}

Doutorando em Educação pelo Programa de Pós-Graduação da Pontifícia Universidade Católica do Paraná, mestre em Educação pela mesma universidade. Especialista em Questão Social numa Perspectiva Interdisciplinar pela Universidade Federal do Paraná. Licenciatura em Letras e Bacharel em Direito. Atua como docente na Rede Estadual de Ensino no Paraná e nos cursos de pós-graduação lato sensu - Política e Gestão Educacional.

\section{JOABIO ALEKSON CORTEZ COSTA}

Graduado em Geografia pela Universidade Federal do Rio Grande do Norte e professor do estado do Rio Grande do Norte.

\section{JOAQUINA MARIA PORTELA CUNHA MELO}

Mestranda do Programa de Pós Graduação em Linguística Aplicada- UNISINOS. Graduada em Letras - Língua Portuguesa e Libras pela Universidade Federal da Paraíba (2014). Atualmente é professora disciplinas Pedagógica/ Libras do Instituto Federal do Piauí. Tem experiência na área de Letras, com ênfase em Educação. Integrante do Núcleo de Atendimento a Pessoas com Necessidades EspecíficasNAPNE no campus Teresina Central. Atuação em sala de aula como intérprete de Libras de 2012 a 2016.

\section{JÚLIA DINIZ DE OLIVEIRA}

Doutoranda em Geografia pela Universidade Federal do Rio Grande do Norte.

\section{KYARA MARIA DE ALMEIDA VIEIRA}

Professora adjunta da Universidade Federal Rural do Semi-Árido (UFERSA), membro permanente do Programa de Pós-Graduação Cognição, Tecnologias e Instituições. Integra o Grupo de Estudos, Pesquisa e Ensino de Sociologia e Ciências Humanas (CNPq), o grupo de pesquisa Núcleo de Investigações e Intervenções em Tecnologias Sociais/NINET (CNPq), o Grupo Flor e Flor Estudos de Gênero e Sexualidade. É membro da Rede Latino-americana de Arquivos, Museus, Acervos e Investigadores LGBTQIA+ (AMAI-LGBTQIA+). Desenvolve e orienta pesquisas sobre Gêneros, Sexualidades, Ensino, Populações do Campo.

\section{LENILDA PEREIRA DOS SANTOS}

Doutoranda em Ciências da Educação, Psicopedagoga, Mestre em Educação pela Universidade Bandeirante de São Paulo (2013), Graduada em Letras (Português e Inglês) (2003) e Complementação em Espanhol pelo Centro Universitário de Santo André(2008) e Graduada em Pedagogia pelo Centro Universitário de Araras Dr Edmundo Ulson -UNAR (2009). 


\section{LILLIAN DA SILVA OLIVEIRA}

Doutoranda em Ciências da Educação pela Universidade Columbia del Paraguay.Mestre em Ciências da Educação pela Universidade Columbia del Paraguay.Especialista em Educação Ambiental pela Universidade Cândido Mendes ( UCAM). Graduada em Ciências Sociais pela Faculdade de Filosofia de Itaperuna ( FAFITA).

\section{LÍVIA VELEDA DE SOUSA E MELO}

Possui Mestrado (2009) e Doutorado (2014) em Políticas Públicas e Gestão da Educação pela Universidade de Brasília (UnB). Foi servidora do Ministério da Educação entre 2005 e 2009, onde participou do Programa de Expansão e Interiorização das Universidades Federais e do Programa de Reestruturação e Expansão das Universidades Federais (REUNI). Participou do Programa Universidade Aberta do Brasil na UnB. Atua em pesquisas sobre a institucionalização da Educação a Distância, Qualidade da EAD, democratização do acesso à educação superior e empregabilidade. Foi professora da educação superior na Faculdade Dulcina de Moraes. Foi professora substituta na Faculdade de Educação da Universidade de Brasília e atual servidora efetiva do quadro da UnB.

\section{LUZIA ALMEIDA DE SOUSA}

Possui graduação em Pedagogia pela Faculdade Santo Agostinho de Teresina - PI (2013). Especialista em LIBRAS pela Faculdade Evangélica do meio Norte ( 2014) Tradutora e Intérprete de LIBRAS pelo Centro da capacitação de Profissionais da Educação e Atendimento às Pessoas com Surdez - CAS / PI ( 2013). Faz parte do quadro efetivo de profissionais do Instituto Federal do Piauí - IFPI ( Campus Teresina Central) com a função de Tradutora Intérprete de LIBRAS e atualmente é uma colaboradora do NAPNE ( Núcleo de Atendimento às pessoas com Necessidades Especificas).

\section{LYDIA DAYANNE MAIA PANTOJA}

Doutora em Engenharia Civil (Saneamento Ambiental) pela Universidade Federal do Ceará - UFC (2016); Mestre em Microbiologia Médica pela Universidade Federal do Ceará (2008) e graduada em Ciências Biológicas pela Universidade Estadual do Ceará (Bacharel - 2007 e Licenciatura - 2006). Atua como Professora Assistente Nível D da Universidade Estadual do Ceará. Docente do Mestrado Profissional em Ensino de Biologia em Rede Nacional - PROFBIO. Coordena a Pesquisa do Curso de Ciências Biológicas a distância - UECE/UAB. É coordenadora de área do Curso Pré-Universitário UECEVest - Biologia. Tem experiência na área de Microbiologia, com ênfase em Microbiologia Ambiental e Aplicada, bem como, desenvolve trabalhos na área de pesquisa em educação a distância e formação de professores.

\section{MARCIA MARIA FUSARO PINTO}

Doutora em Educação Matemática pela Universidade de Warwick, na Inglaterra, e mestre em Matemática pela UFMG, onde foi docente do programa de Pós Graduação em Educação, da Faculdade de Educação. Atualmente é professora no Instituto de Matemática da UFRJ. É membro do Programa de Pós Graduação em Ensino de Matemática e do Grupo de Pesquisas Matemática no Ensino Superior e Tecnologias. Foi membro do comite internacional do International Group for the Psychology of Mathematics Education no período 2008 a 2012. Na pesquisa, tem interesse por abordagens socioculturais na psicologia da educação matemática e sobre tecnologias na educação matemática. 


\section{MARIA DE LOURDES ROSSI REMENCHE}

Professora Adjunta III da Universidade Tecnológica Federal do Paraná (UTFPR) com pós-doutorado em Educação pela Universidade do Minho (UM - PT). Doutora em Linguística pela Faculdade de Filosofia e Letras da Universidade de São Paulo (USP), Mestre em Estudos da Linguagem (UEL), Especialista em Língua Portuguesa (UEL) e Graduada em Letras Vernáculas e Anglo (UEL). A pesquisadora é docente do Programa de Pós-Graduação em Estudos das Linguagens/PPGEL, líder do Grupo de Pesquisa em Linguística Aplicada (GRUPLA), e desenvolve pesquisas na área de Letramentos, Multiletramentos, Discurso, Produção de sentido, Práticas de leitura e escrita na contemporaneidade.

\section{MARIANA FIGUEIRA SECAFIM}

Mestra em Educação, na linha de pesquisa: Educação Matemática pelo Instituto de Educação da Universidade Federal de Mato Grosso (UFMT/Cuiabá). Possui graduação em Matemática pela Universidade Federal de Mato Grosso (2015). Tem experiência na área de Matemática, com ênfase em Matemática, atuando principalmente nos seguintes temas: educação matemática, materiais manipulativos, jogos matemáticos, resolução de problemas, metacognição e educação de jovens e adultos. É professora efetiva da Secretaria Estadual de Educação de Mato Grosso (SEDUC/MT)

\section{MARLON MESSIAS SANTANA CRUZ}

Licenciado em Educação Física pela Universidade do Estado da Bahia-UNEB-Campus XII. Especialista em Metodologia do Ensino e Pesquisa em Educação Física Esportes \& Lazer pela LEPEL - FACED - UFBA (Universidade Federal da Bahia). Mestre em Educação e Contemporaneidade pela UNEB - Campus I. Doutorando em Memória, Linguagem e Sociedade na UESB (Universidade Estadual do Sudoeste da Bahia). Tem experiência na área de Educação Especial, Educação Regular e Formação de Professores, com ênfase em Educação Física Escolar. Professor Pesquisador do GRUPO AGENTE. Professor Assistente da Universidade do Estado da Bahia. UNEB - Campus XII (Guanambi). Professor da UNIFG - Centro Universitário.

\section{MARTA MARIA PONTIN DARSIE}

Possui graduação em Pedagogia, com habilitação em Docência e Supervisão Escolar (1982) e habilitação em Admisnistração Escolar (1983) pela Faculdade de Filosofia Ciências e Letras de Palmas. Especialização em Formação e Atuação do Educador na Realidade Educacional, pela Faculdade de Filosofia Ciências e Letras de Palmas (1984); especialização em Metodologia do Ensino de Matemática de $1^{\mathrm{a}}$ à $4^{\mathrm{a}}$ série pela Universidade Federal de Mato Grosso (1986). Mestrado em Educação pela Universidade Federal de Mato Grosso (1992) e doutorado em Educação pela Universidade de São Paulo (1998). É professora da Universidade Federal de Mato Grosso desde 1986, e professora pesquisadora do Programa de Pós-Graduação em Educação da Universidade Federal de Mato Grosso desde 1999. Líder do grupo de estudos e pesquisas em Educação Matemática - GRUEPEM. Atualmente é Coordenadora Geral do Programa de Pós Graduação em Educação em Ciências e Matemática- PPGECEM, doutorado da Rede Amazônica de Educação em Ciências e Matemática-REAMEC; coordenadora do Projeto Observatório da Educação com foco em Matemática e iniciação às Ciências do Polo UFMT-Cuiabá. É pesquisadora na área de Educação, com ênfase em Ensino de Ciências e Matemática, atuando principalmente nos seguintes temas: educação matemática, formação de professores, avaliação da aprendizagem, avaliação em larga Escala - ALE, metacognição e matemática, Dificuldades de aprendizagem Matemática-DAM, Educação de Jovens e Adultos. 


\section{MAYARA LOPES DE FREITAS LIMA}

Atualmente é mestranda em Ensino das Ciências pelo Programa de Pós- Graduação em Ensino das Ciências (UFRPE), na linha de Processos de construção de significados em ensino de Ciências e Matemática e é integrante do Grupo de Pesquisa: Museus, Pesquisa e Investigação - MuPI, com a linha de pesquisa intitulada: Ubiquidade e engajamento em espaços não formais. Especialista em Docência no Ensino Superior e em Ensino de Biologia (Universidade Cruzeiro do Sul). É licenciada em Ciências Biológicas pela Universidade Federal de Pernambuco.

\section{MESSIAS VILBERT DE SOUZA SANTOS}

Graduação em Licenciatura em Física pela Universidade Federal de Pernambuco (2003 - 2007); Mestrado em física teórica pela mesma instituição (2008 - 2010). Doutorado em física pela Universidade Federal de Pernambuco $(2011$ - 2015). Tem experiência na área de Física, com ênfase em teoria de campos, grupo de renormalização, fenômenos críticos e sistemas competitivos do tipo Lifshitz. Professor efetivo do IFRN - Campus Parelhas (2016 - 2019). Atualmente é professor efetivo do IFRN - Campus Nova Cruz.

\section{NARA MARTINI BIGOLIN}

Doutora em Ciência da Computação pela Université Pierre et Marie Curie. Professora Associada da UFSM - Universidade Federal de Santa Maria - Campus Frederico Westphalen/RS

\section{NILMA DE PAULA CALADO}

Professora de Educação Especial com atendimento em sala de recursos no município do Cabo de Santo Agostinho-PE desde 2011, com formação em Licenciatura Plena em Educação com Pósgraduação em Educação Especial na Perspectiva da Inclusão e Mestrado em Ciência da Educação em andamento.

\section{OTÁVIO VIEIRA SOBREIRA JÚNIOR}

Funcionário Público do Estado do Ceará, atualmente lotado como Orientador da Célula de Formação, Programas e Projetos da SEFOR, atuando diretamente com a Formação de Docentes e Coordenadores Escolares. Trabalhando como Tutor à Distância e Professor Formador do Curso de Ciências Biológicas da Universidade Estadual do Ceará (UECE/UAB). Membro do corpo docente da Faculdade Vale do Jaguaribe. Possui graduação (Licenciatura e Bacharelado) em Ciências Biológicas pela Universidade Federal do Ceará (2010), pós-graduação Latu Sensu em Gestão Escolar e Coordenação (540 Horas) pela Faculdade Católica Nossa Senhora das Vitórias.

\section{PROF. DR. MARCELLO FERREIRA}

Professor no Instituto de Física da Universidade de Brasília (UnB), onde atua como vicecoordenador no Programa de Pós-Graduação em Ensino de Física. Atualmente, é Coordenador-Geral da UAB na UnB. Doutor em Educação em Ciências pela UFRGS, mestre em Ensino de Física e licenciado em Física pela UnB. Realizou Estágio Pós-Doutoral na UFSCar, na área de Ensino de Ciências e Tecnologias. Pesquisa e orienta nos temas: fundamentos teórico-metodológicos para o ensino de ciências e física; formação de professores de física; currículo; estudos foucaultianos; educação a distância; e políticas públicas da educação. Pesquisador CAED/UFJF na área de avaliação digital em física. Integra e atualmente é vice-coordenador da Comissão Nacional de Pós-Graduação do MNPEF/SBF. Possui experiência como gestor de políticas públicas em educação, tendo exercido os cargos de Coordenador de Articulação Acadêmica e Coordenador-Geral de Programas e Cursos em EaD na Capes. Foi também professor, Coordenador de Planejamento, Desenvolvimento e Avaliação e Pró-Reitor de Assuntos Estudantis e Comunitários da Universidade Federal do Pampa. 


\section{PROFA. DRA. LETÍCIA LOPES LEITE}

Possui graduação em Informática pela PUCRS (1997), mestrado em Ciência da Computação pela UFRGS (2000) e doutorado em Ciência da Computação pela PUCRS (2012). Foi professora da Pontifícia Universidade Católica do Rio Grande do Sul no período de 2001 a 2015. Atuou como gerente e coordenadora de cursos de extensão e especialização a distância, junto à PUCRS Virtual. Na Pró-Reitoria Acadêmica da PUCRS ocupou os cargos de Coordenadora de Ensino e Coordenadora de Desenvolvimento Acadêmico. Coordenou o Projeto LabsMóveis, vencedor do Prêmio Inovação em Educação (SINEPE/RS), categoria Gestão Pedagógica (2014). Coordenou os cursos de Bacharelado em Sistemas de Informação e Tecnólogos em Redes de Computadores, em Sistemas de Telecomunicações e em Sistemas para Internet, da FACIPLAC/DF. Atua como professora adjunta do Departamento de Ciência da Computação (CIC/UnB). No CIC é professora do Programa de PósGraduação em Computação Aplicada, é membro do Núcleo Docente Estruturante do Curso de Licenciatura em Computação e da Comissão de Graduação do Departamento, representa como suplente o Instituto de Exatas na Câmara de Graduação. Atualmente, é Diretora do Centro de Educação a Distância da Universidade de Brasília (CEAD/UnB).

\section{QUEZIA ASSIS DE SOUSA}

Técnica em Informática pelo Instituto Federal de Educação, Ciência e Tecnologia do Rio Grande do Norte.

\section{RAFAEL SILVA PATRÍCIO}

Possui graduação em Licenciatura em Matemática pela Universidade do Estado do Pará (2002) e Mestrado em Educação em Ciências e Matemáticas pela Universidade Federal do Pará (2010). Atualmente é aluno de Doutorado em Educação no PPGE - Universidade Federal de São Carlos - SP. É Professor efetivo da Universidade do Estado do Pará - UEPA. Tem experiência nas áreas de Matemática e Educação Matemática, com ênfase em Matemática Financeira, Geometria Analítica e Formação de Professores. É membro do grupo de Pesquisa Ciência, Tecnologia, Meio Ambiente e Educação não-formal - CTENF.

\section{RODRIGO CORSINO LOPES}

Licenciado em Matemática pela Universidade do Estado do Amazonas (2016) e pós-Graduação Lato Sensu em Metodologia de Ensino de Matemática pela UNIASSELVI (2020). Atualmente é professor de matemática - ensino fundamental do CENTRO EDUCACIONAL LA SALLE MANAUS e professor de matemática - ensino médio - Secretria de Estado da Educação e Qualidade de Ensino do Amazonas. Tem experiência na área de Matemática, com ênfase em Matemática, atuando principalmente nos seguintes temas: matematica, aprendizagem significativa, uso de tecnologias, tecnologia e material concreto.

\section{SANDRO RENÉ CUNHA}

Doutorando em Ensino de Matemática pela Universidade Federal do Rio de Janeiro (UFRJ). Mestrado e Especialização na mesma área e na mesma instituição. Atualmente é professor do curso de Engenharia de Produção da Universidade Cândido Mendes (UCAM). Dedica-se a atividades acadêmicas envolvendo a linha de pesquisa Ensino de Matemática, com interesse em questões referentes ao contexto da sala de aula no ensino superior, incluindo estudos de novas perspectivas teóricas e metodológicas na investigação desses problemas, com enfoque em pontos cruciais como o Pensamento Lógico-Dedutivo, o Formalismo Matemático, e a Construção de Estruturas Matemáticas Abstratas. 


\section{SERGIO ANTÔNIO ANDRADE DE FREITAS}

Atualmente Professor Associado 4 da Universidade de Brasília (UnB) e Decano (Pró-Reitor) de Ensino de Graduação da UnB. Foi diretor do Centro de Educação a Distância da UnB e coordenador de pesquisa no Laboratório da Fábrica de Software da FGA. Seus projetos de pesquisa atuais se concentram em estudos interdisciplinares e aplicações de metodologias de aprendizagem em cursos de graduação em engenharia e metodologias de engenharia de software. Suas áreas de interesse incluem gamificação, PBL, ambientes virtuais de aprendizado em educação e treinamento e metodologias de engenharia de software. É autor de publicações em periódicos, artigos de conferências e capítulos de livros. Coordenou e participou de vários projetos de várias agências de fomento do CNPq, FAP-ES, FAP-DF, Cebraspe e ministérios federais brasileiros.

\section{SIDNEI RENATO SILVEIRA}

Doutor em Ciência da Computação pela UFRGS - Universidade Federal do Rio Grande do Sul. Professor Adjunto do Departamento de Tecnologia da Informação da UFSM - Universidade Federal de Santa Maria - Campus Frederico Westphalen/RS.

\section{SINAIDA MARIA VASCONCELOS}

Licenciada em C. Biológicas (UFPA); Mestre em Educação em Ciências e Matemáticas (UFPA); Doutora em Educaçao (PUC-Rio). Atualmente é Professora Adjunto III da UEPA, atuando no Curso de Lic. C. Biológicas e no PPG em Ensino e Educação em Ciências na Amazônia, no qual é Vicecoordenadora. Também foi docente e Coordenadora do Curso de Lic. em Ciências Biológicas do CESUPA (2006 a 2013). Tem experiência na área de Educação, com ênfase em Educação em Ciências, atuando principalmente nas seguintes áreas: Divulgação Científica; Educação não formal ; Formação de Professores de Ciências e Biologia. Foi Diretora do Centro de Ciências e Planetário do Pará (2013 -2019) . Coordena o Grupo de Pesquisa Ciência Tecnologia, Meio Ambiente e Educação não formal.

\section{SIRLÂNIA SOUZA SILVA}

Atua como professora da Educação Básica na rede estadual e municipal em Iturama-MG. É especialista em Educação Física Escolar pela Universidade Federal de Goiás (UFG)- 2019. Licenciada em Educação Física pela Universidade do Estado da Bahia (UNEB) - Campus XVII (2015). E se dedica estudar o campo da Educação Física Escolar.

\section{TANIA MARIA DOS SANTOS}

Possui graduação em Normal Superior pelo Instituto Superior de Educação Antonino Freire (2008). Graduação em Pedagogia pelo Instituto Superior de Educação São Judas Tadeu ( 2013). Graduação em Letras Espanhol pela Universidade Estadual do Piauí - UESPI (2017). Especialização em Supervisão Educacional com Docência do Ensino Superior pela Faculdade de Ensino Superior do Piauí (2011). Especialização em LIBRAS pela Faculdade Evangélica do Meio Norte (2014). Mestranda do curso de Linguística Aplicada pela Universidade do Vale do Rio dos Sinos - UNISINOS. Atualmente é professora intérprete de Libras da Secretaria Estadual de Educação do Maranhão. Tem experiência na área de Educação, com ênfase em Educação Especial, Libras. 


\section{TERESINHA DE JESUS ARAUJO MAGALHÃES NOGUEIRA}

Professora efetiva da Universidade Federal do Piauí (UFPI), com dedicação exclusiva. Atualmente atua em Acordo de Cooperação com a Universidade de Brasília (UnB). Doutora em Educação pela Universidade Federal do Piauí (UFPI), com doutorado Sanduíche no Instituto de Educação da Universidade de Lisboa (IEUL). Mestre em Educação pela UFPI. Pós-graduada em Políticas Públicas e em Marketing pela UFPI. Graduada em Pedagogia pela Universidade Estadual do Piauí (UESPI). Foi coordenadora do Curso de Pedagogia na UFPI. Na Universidade Aberta do Brasil (UAB/UFPI) atuou como pesquisadora na elaboração de conteúdo e coordenação de disciplina. Membro do Núcleo de Educação História e Memória (NEHME/UFPI). Apresenta publicações em encontros internacionais, publicações em anais e periódicos, organização e produção de livro e capítulos em livros. Desenvolve pesquisa na área de formação de professores, inovação educacional, prática educativa, prática pedagógica, avaliação da aprendizagem, história e memória da educação, instituições educativas e educação a distância.

\section{WALTER MARTINS RODRIGUES}

Possui graduação em Licenciatura em Matemática pela Universidade de São Paulo (IME-USP), onde também cursou o mestrado em Matemática, e também doutorado na área de Álgebra. Atualmente é professor Associado UFERSA, exerceu a atividade de coordenador Pedagógico e pró-reitor adjunto de Graduação, Cursou pós doutorado em matemática no IME-USP , ministra aulas de álgebra no curso de licenciatura em Matemática, e no mestrado em Matemática da UFERSA (PROFMAT), trabalha com pesquisa voltada para modelagem matemática aplicada, ensino de Matemática e estudos das algebras de Colombeau. 


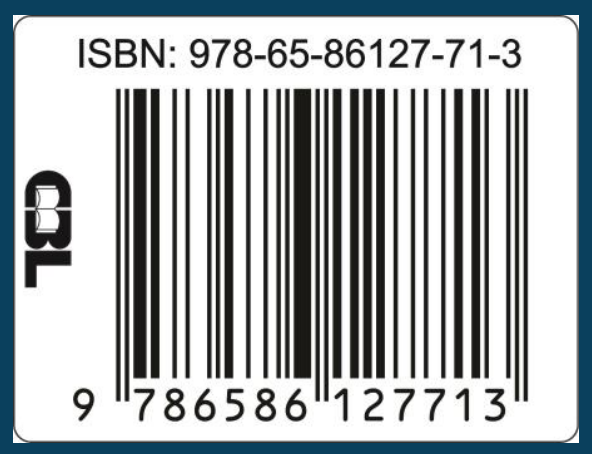

